$$
\therefore \leq 1996
$$

ORNL-5019

Theoretical and Experimental Stress Analyses of ORNL Thin-Shell Cylinder-To-Cylinder Model 4

$\begin{array}{lll}\text { R. C. Gwaltney S. E. Bolt } & \text { S. }\end{array}$

J.W. Bryson 
Printed in the United States of America. Avaibate trom National Technical Information Service U.S. Department of Commerce

5285 Port Royal Road. Springtield, Virginia 22161

Price: Printed Copy 57.60: Miorsfiche $\$ 2.25$

\begin{abstract}
This report was prepared as an account of work sponsoere by the United States Governme-r. Netther the United States nor the Energy Research and Dewelopment Adminustration, nor any of itheir emaloyes. nor any of inew contractors. subconeractors, or theil employes, makes any marranty, express or implied. Or

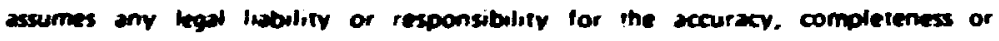
usefulness of any infermation. apowatus. product or process disclosed. or eepresents that its use would not mitringe privatety owned ringhts.
\end{abstract}

1 
ORKL-5019

UC-79, -79h, $-79 x$

Contract No. W-7405-eng-26

Reactor Jivision

THEORETICAL AND EXPERIMENTAL STRESS ANALYSES OF CRNL TH IN-SHELL CYLINLER-TO-CYLIDDER MODEL 4

R. C. Ghaltney S. E. Eolt

J. W. Bryson

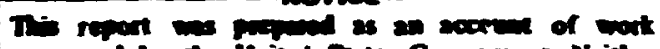

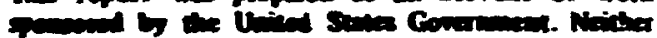

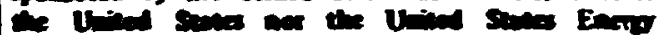

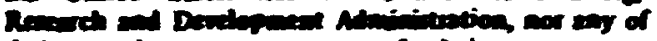

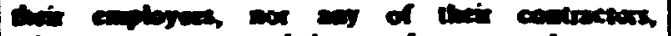

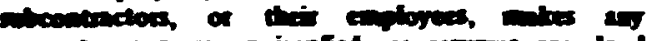

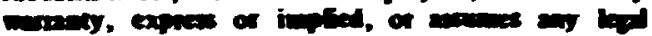

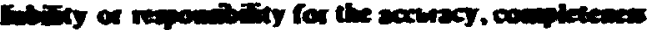

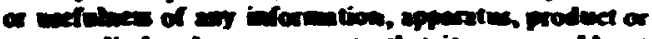

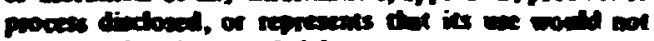

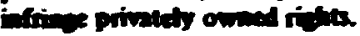

JUNE 1975

OAK RIDGE NATIONAI LABORATORY

Oak RIdqe, Tennessee 37830

operated by

UNION CARBIDE CORPORATION

for the

U.S. ENERGY RESEARCH AND DEVELOPMENT ALMINISTRATION 


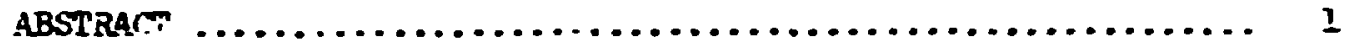

1. IrrRonuction $\ldots \ldots \ldots \ldots \ldots \ldots \ldots \ldots \ldots \ldots \ldots \ldots \ldots \ldots \ldots \ldots$

2. EXPERIMETTAL ARALISIS $\ldots \ldots \ldots \ldots \ldots \ldots \ldots \ldots \ldots \ldots \ldots \ldots$ i

2.1 Model Constrictior ...................... 5

2.2 Strain-Gage iayout ...................... ;

2.3 iest Description ........................ $\delta$

2.4 Data Acquisition and Reduction .............. 13

2.5 Veriations of Maximim Measured Stresses Around iozzle-Cylinder Jusction .................. 14

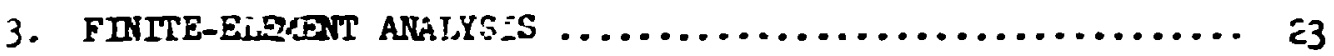

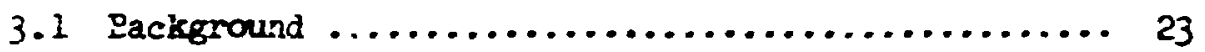

3.2 Finite-Element Method $\ldots \ldots \ldots \ldots \ldots \ldots \ldots \ldots \ldots \ldots$

3.3 Finite-Elenent Idealization of Kodel .......... 30

4. COMPARISON OF IHECRY A.D EXPERIMENT .............. 32

4.1 Internal Pressure $\ldots \ldots \ldots \ldots \ldots \ldots \ldots \ldots \ldots \ldots \ldots \ldots$

4.2 Out-of-Elare Morrent Loading, $\mathrm{M}_{\mathrm{XV}}$, on Nozzle ...... 34

4.3 Torsional Moment Loading, MyN, on Nozzle ........ 34

4.4 In-Plane liomert Loading, $\mathrm{K}_{\mathrm{ZN}}$, on Nozzle ........ 3;

4.5 In-Plane Force, $F_{X N}$, on Nozzle ............. 35

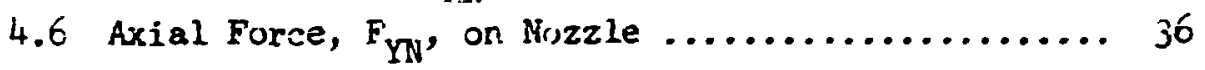

4.7 Ont-of-Plane Force, $F_{Z N}$, on Nozzle ........... 36

4.8 Torsional Moment Loading, $\mathrm{K}_{\mathrm{xc}}$, on Gilinder ...... 37

4.9 Out-of-Plane Moment Loading, $\mathrm{M}_{\mathrm{YC}}$ on Cylinder ..... 37

4.10 In-Plane Miment Loading, $\mathrm{ZC}$ on Cylinder ....... 33

4.11 Axial Force, $F_{X \tilde{C}}$, on Cylinder $\ldots \ldots \ldots \ldots \ldots \ldots . \ldots \ldots$

4.12 In-Plane Force, $P_{1 C}$, on Cylinder $\ldots \ldots \ldots \ldots \ldots . \ldots 38$

4.13 Out-of-Plane Force, $F_{Z C}$, on Cylinder ......... 39

5. Conclustons $\ldots \ldots \ldots \ldots \ldots \ldots \ldots \ldots \ldots \ldots \ldots \ldots \ldots \ldots$.

ACKNOWLEDGETTS $\ldots \ldots \ldots \ldots \ldots \ldots \ldots \ldots \ldots \ldots \ldots \ldots \ldots \ldots \ldots$ L.2

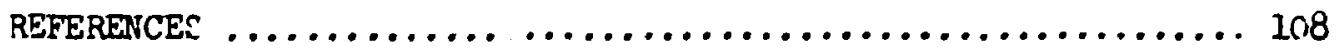

APPENUIX, TABULATION OF EX KERTMENTAL DATA $\ldots \ldots \ldots \ldots \ldots \ldots \ldots 11$ 
THEORETICAL AND EXPERLEATHL ITRESS AMATSES OF ORA: THIN-SHELC CYLIDER-TO-CY:INDER MAIEI 4

\author{
3. C. Graltney S. E. Bolt \\ J. U. Bryson
}

\begin{abstract}
AESTRACT
The last in a series of four tha-sieil a cylinier-tc-cylinder sodeis was tested, and the experi-entsily deternined elastic stress distritutions vere compared ritt. theoretical predictions obtained from a thin-she?l finite-eliment anaysis. The models in the series are idealized taia-sheil structures consisting of two circular cylindrical shellis thit intersent at right angles. There are no trasitions, reiriorsenents, or fi!lets in the junction region. This series of poiel tests serves two basic purposes: (1) the experinental tat forvide desion information directly applicable to nozzles in $\$$ ! fuis:cal vessels, and (2) the idealized models provide test zessilts for use in developing and evalunting theoretical analyses iplizabie to rozzles in cylindrical ressels and to thin pipir.s tees.

The cylinder of matei 4 had an outside iiameter of 10 in., and the nozzle had ar out,side lianeter 0:" 1.29 in., giving a $d_{0}$ ' $D_{0}$ ratio of 0.129 . The $O D$. thickress rat:os were 50 and 20.2 for the cylinder and nozzle respectiviy. Thirteen separate loading cases were amalyzed. For cach loading condition one end of the cylinder was rigidly held. In acidition to an incernal pressure laading, three mutuallir perperiticular force components and three mutually perpenticular moment components were individuslly applied at the free end of the cylinder and at the end of the rozzle. The experimental stress di 3 tributior.s for each of the 13 loadings were obtained using 157 three-gage strain rosettes located on the inser and outer surfaces.

Each of the 13 loading cases was also analyzed theoretically using a finite-element shell analysis developed at the University of California, Berkeley. The analysis used flat-plate elements and considered five degrees of freedom per node in the final assembled equations. The comparisons between theory and experiment show reasonably good agreement for this model.
\end{abstract}

\title{
1. DNTRODUCTION
}

Intersecting cylindrical shells are comnon configurations in structural components for nuclear reactor systems. Piping tees and nozzles in cylindrical vessels are specific examples. However, despite their common 
vecurrence, proren elastic stress analysis methods for such corfigurations have not been senerally available, and oriy recently have potential analyses been jeveloped. This is true even for tine case of an idealized configuration consisting of two thin-shell normally intersecting cylinders with no transitios, reinforcenents, or fillet.s in the junction region.

To seet the need for experimental lata obtained from carefuily wrchinel zodels, Oak Ridge Mational Laboratory (ORH) has testel a series of four thin-shell cylinjer-to-cylinder models. In addition to providing test results for use in jeveloping and evaluating potential analytical teciniques, the modeis will provide design information directly policable to rozrles in cylintrical vessels and to a class of thin piping tees as rell. The test results will be particilarly applicable to liquid-metalcosled fast treejer reactor components in wich relatively low internal pressures ani kigh thermal transients jictate the use of thin-walded structures.

The four aoiels have been tested, and the experimentally jetermined stress distributi.ns have been compared with the predictions of a thinsnell finite-element analysis. This report describes the test $\Sigma$ and analyes of noje: i ani prezents somparijons of theory and experiment. The tests and analyses for models 1 and 3 are described in Refs. I to 3.

Model 4 is show in Fig. I aiong with a listing of the significant iimensions of ail four moiels in the series. As indicated by the figure, these rodels are truly idealized shell structures. There are no transitions, fillets, or reinforcing in the junction region. The outside diameter $D_{0}$ of the cylinder of the lourth model was 10 in., and the outside diameter $d_{0}$ of the nozzle ras 1.29 in. giving a $d_{0}^{\prime} d_{0}$ ratio of 0.129 . The cylinder thickness $T$ was 0.2 in., and the nozzle thickness $t$ was 0.064 in. Thus the $O D$ thickness ratios of the cylinder and nozzle were 50 and 20.2 respectively. The fourth model was obtainea from the third by boring out the nozzle to provide a thinner wall thickness.

Aodel 4 is shown schematically in Fig. 2, together with the applied forces and moments to which it was subjected and the major dimensions. One end of the model was rigidly fixed, or "built-in," as shown, while external loads were applied to the free end of the cylinder and to the end of the nozzile. Three mutually perpendicular force components and three 


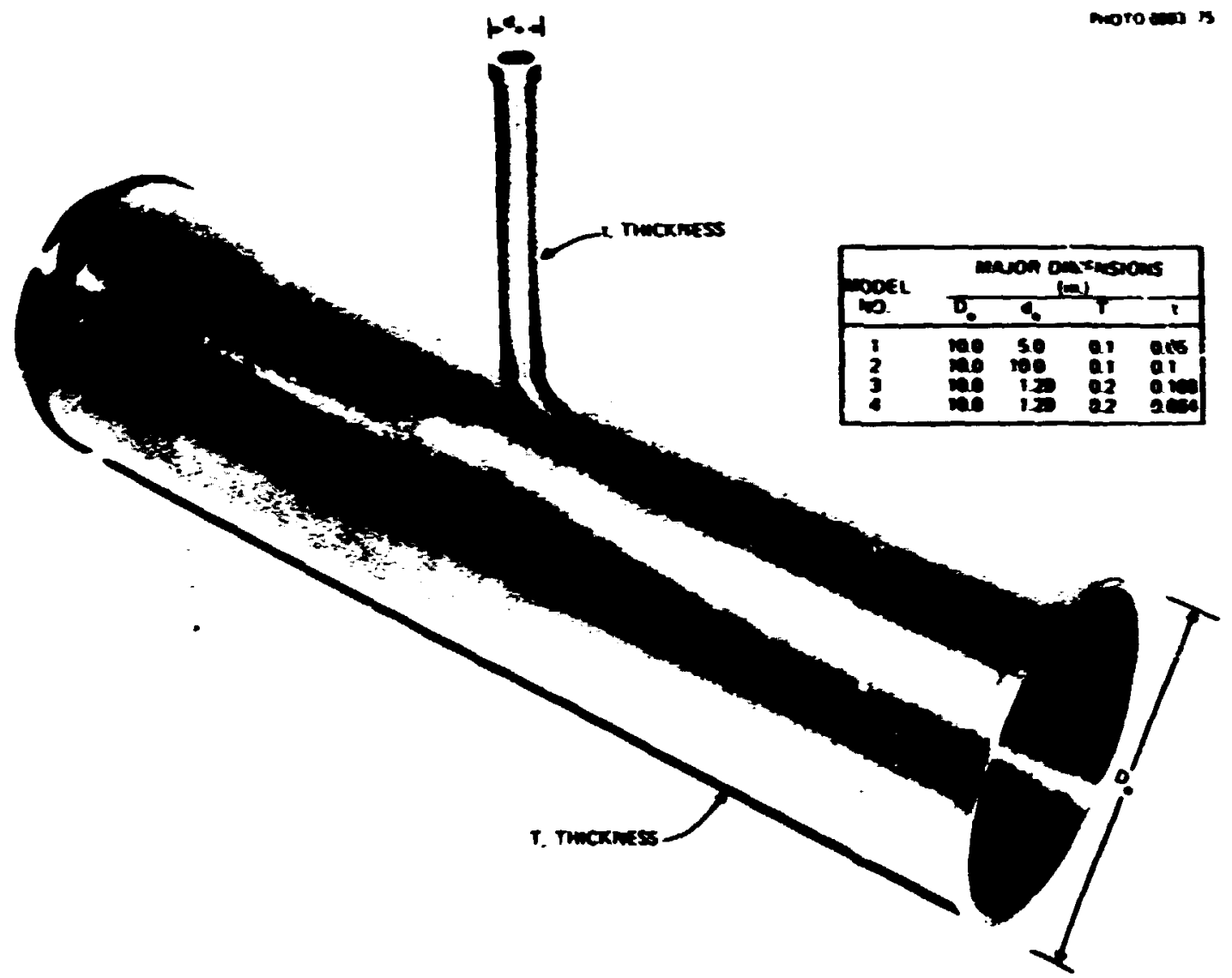

Fig. 1. Thin-shell cylinder-to-cylinder model 4 and table of dimensions for all four models in test series.

mutually perpendicular moment components were applied individually at each location. Thus, including internal pressure, there was a total of 13 loading cases. These loading cases were examined both experimentally and analytically, and the results were compared for each loading case.

Chapter 2 of this report describes the testing aspects of the experimental anelysis and also the strain-gage data-acquisition and reduction techniques used. Representative experimental results, in the form of maximum measured stress distributions around the nozzle-cylinder junction, are presented for each loading. The finite-element analysis, discussed in Chap. 3, includes a brief description of the formulation used and the specific element layout for the model. Complete comparisons of theory and experiment for all 13 loading cases are presented and discussed in Chap. 4, and Chap. 5 contains a concise sumary of the conclusions drain from the 


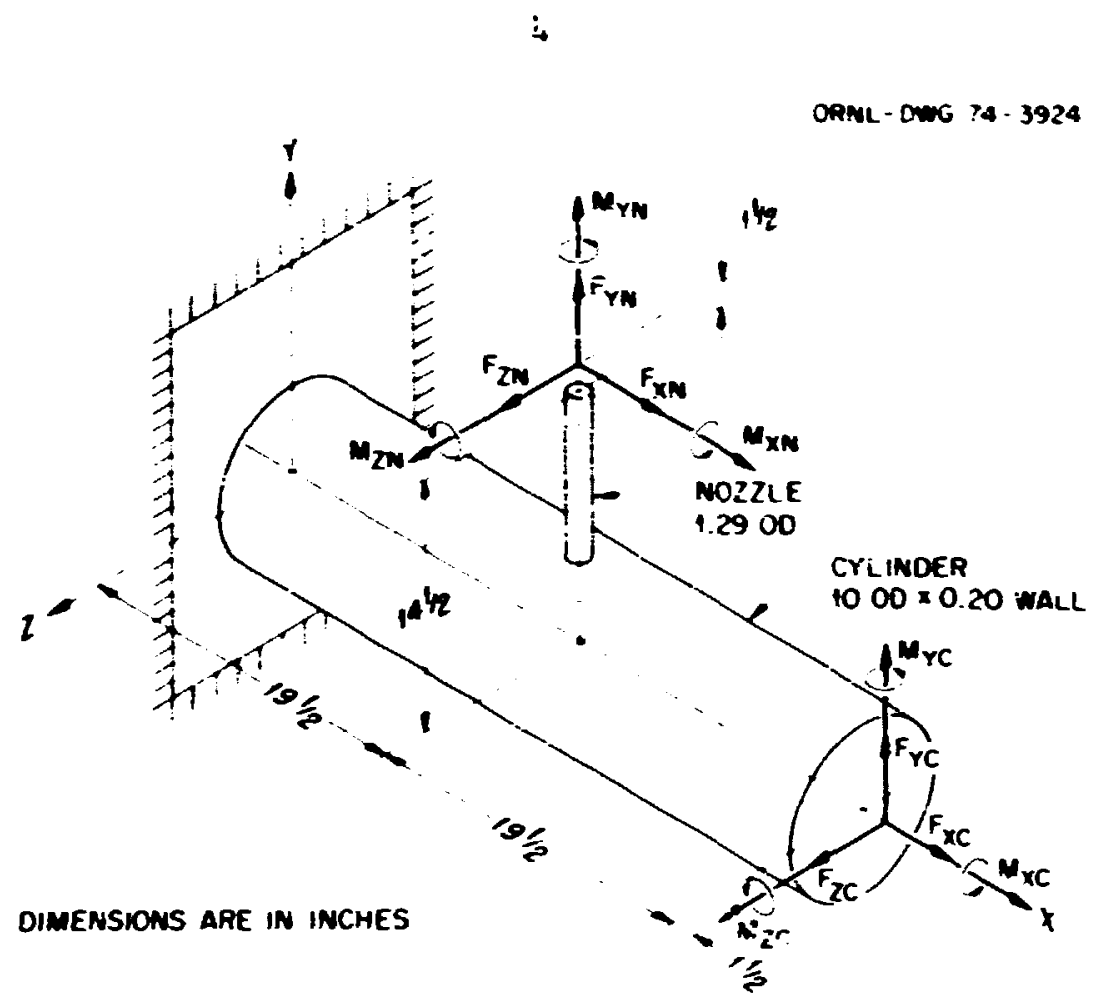

Fig. 2. Schematic of model 4 showing applied external laadings.

study of model 4. For the benefit of the reajer who wishes tr use the experimental data for comparisons with his own analyses, an appendix is included that gives a complete set of experimental data for each of the 13 looding cases.

\section{EXPERIIETTAL ANALYSIS}

In experimental investigations of thin-shell cylinder-to-cylinder pressure vessel configurations, botr, strain-gage metal models and photoelastic models have been lise. Strain-gage studics for internal pressure and for external nozzle loadings have been carried out by Hardenbergh, Zamrik, and Edmondson; ${ }^{4}$ by Hardenbergh and Zamrik; ${ }^{5}$ and by Rilay. ${ }^{6}$ Conisured and reinforced outlets were used in the first two studies; in the third, the model was fabricated from hot rolled sheet steel by welding. In photoelastic studies carried out by Taylor and Lind $^{7}$ and by Leven, ${ }^{8}$ reinforced openings were examined. Thus, of the previous studies, on? $y$ that of Riley ${ }^{6}$ used a thin-shell idealized cylinder-to-cylinder metal model, and it was of welded construction rather than being carefully machined. 


\section{$\ddot{z} .1$ Yodel Construction}

Ure of the primary ofjectives of tive experifextal aralysis lescribez in this report was to ottain experi-ental iats on a sarefully aachines oylinier-to-rylinjer moiel so that the fffects of gexetrical inperfections rouli be =irimizei.

Tre casic configuration was otainei by forging. i carton steel $5:-$ let was :orsei into the shape of a tee and ther annealej. Fre forgine was then borei out to the rough insile inensions, ari the outsine ras rout machinei. Tre structure was anneales a second tire. To zaintain tre sorrect jizensions jurizz arnealing, a tight-fitting Eraphite zarirel was =achine: an: insertei in soth the nozzle and cylinjer. The insice surfaces were then mashired to the final limersions by borine. The final zachinir on the outsije surface as jore or a tracing-type uilling eachine usirg a carefully construct=i marogeny wooi gatters. The alore iescription iescribes the marufacture oi moiel 3; mijul it was ottained by boring out the nozzle of tojei 3 .

\subsection{Strain-Gase jayout}

The roiel was instmentei with electric resistance strain zages on both the outside and inside surfaces. ictuaily only the inside surface of the rozz'.e hai to be strain gaged, since mojel 4 was made from model $j$ iy boring out the nozzle. A surficient number of gages was used on this model to provide a good description of the stress distributions for comparisons with predictions and for identifying the high-stress regions.

The strain-gage laycuts for the outer and inner surfaces are shown in Figs. 3 and 4 respectively. A total of 157 three-gage strain-gage rosettes was used, a total of 471 inividuai strain gages. There were 84 rosettes on the outer surface and 73 on the inner surface. These were, in most cases, located "back to back" at the locations shown in Figs. 3 and 4.

The gages were arranged in two opposite quadrants along lines running from the junction of the nozzle and cylinder. In one quadrant there are three lires of gages at $45^{\circ}$ intervals, while in the other quadrant there are two lines of gages at $90^{\circ}$ intervals with only six rosettes in a line on each surface. 


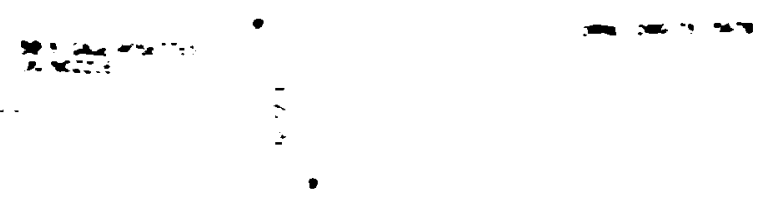

-
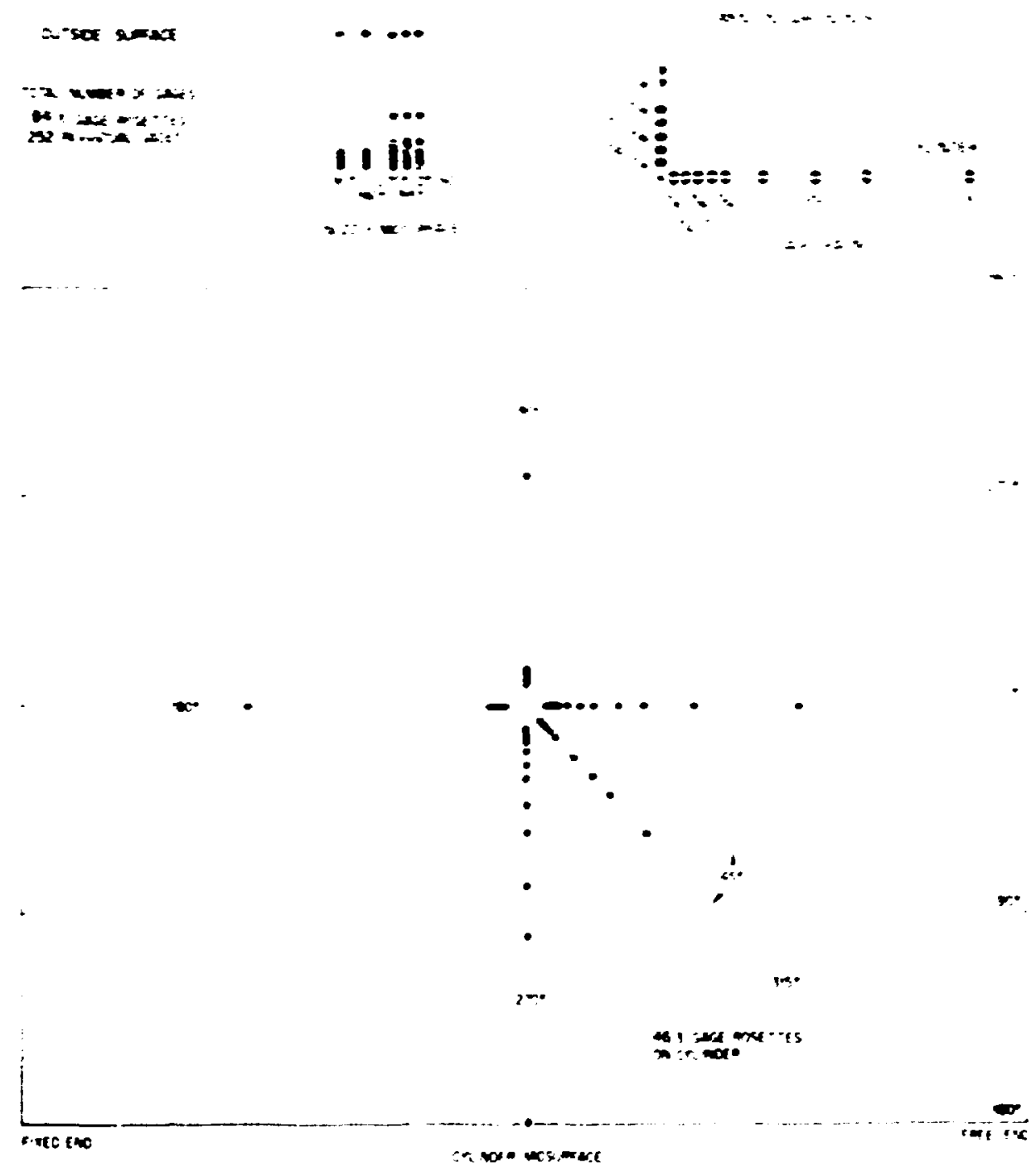

Fig. 3. Strain-gage layout on the outer surface. 

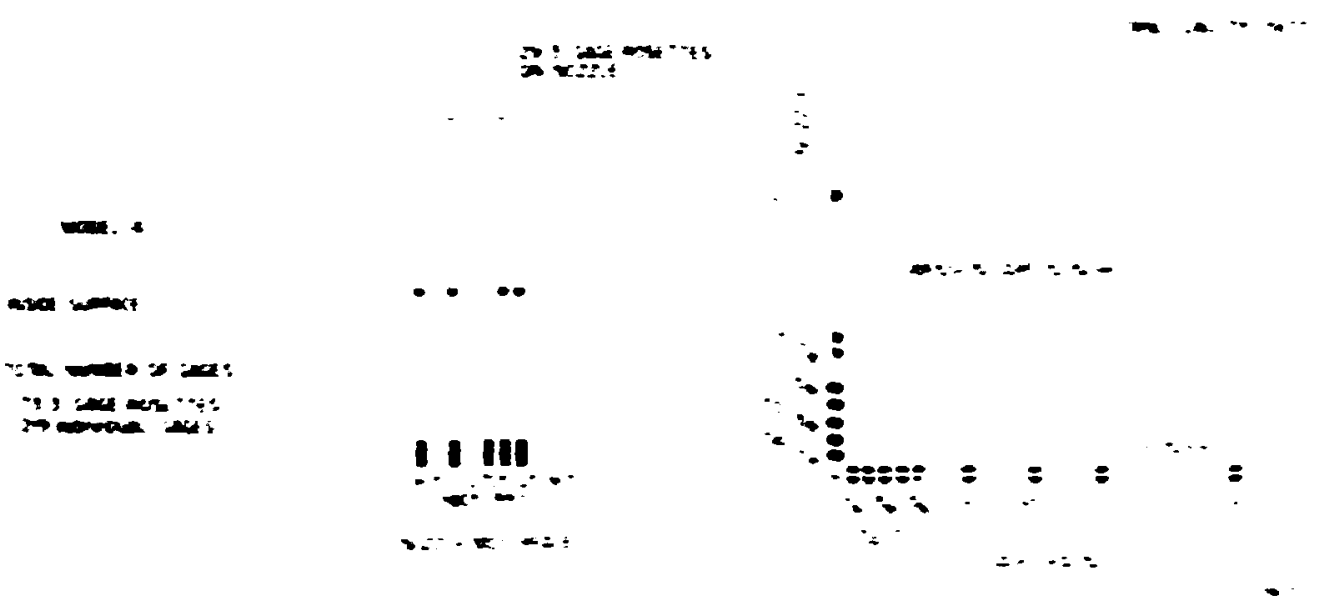

$-$

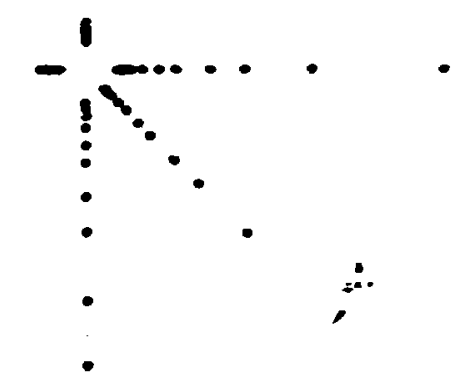

$i m$

?...

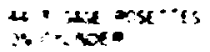

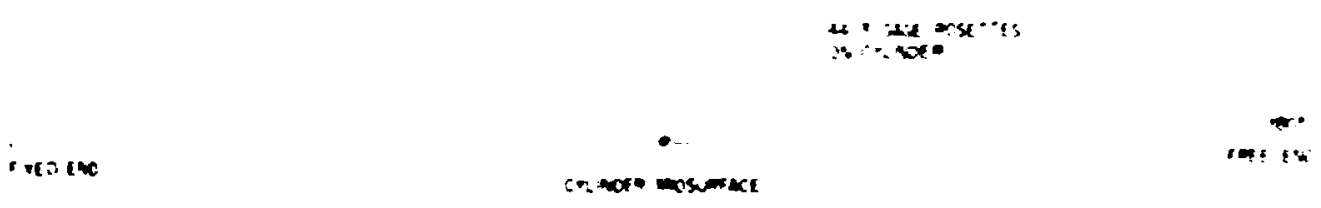

Fig. 4. Strain-gage layout on the finner surface. 
There were tro principal reasons for gaging two opposite quadrants. First, for the majoxity of the 13 loadings the behavior in the two quadrants was expected to be different. Second, for loadings such as internel pressure, where the behavior should be identical, experimental data from two supposedly identical quadrents allow a check of the data and provije scue indication of the effects of geometrical imperfections in the mokel.

The three-gage rosettes usea were Micro-Measurements type EA-06-030YB120, option $\mathrm{SE}$, which is a very compact three-gage foil rosette. The three individual gages are arranged in a " $Y$ " pattern and have ar individua? gace length of $0.030 \mathrm{in.}$. As can be seen in the inset in the urper right-hand corner of Fig. 3, five conplete rosettes were lockted along each gage line within the first 58 in. from the junction. These first five rosettes were suppliel mountea on a comon backing by the gage nanufacturer. These assemblies have the sane designation as the single rosettes except that the sption becomes Bi27. One of the five-rosette assemblies is shown in Fig. 5.

The rcsettes were applied with an epoxy adhesive, BR-610, which is available from $W$. T. Bean, Inc. Cliring times and teroperatures ranged fram $10 \mathrm{hr}$ at $25,0^{\circ} \mathrm{F}$ to $24 \mathrm{hr}$ at $200^{\circ} \mathrm{F}$. Uninsulated $4-\mathrm{mil}$-diam wire was used to connect the gages to temninal tabs to which larger lead wires were connected. The strain-gage data were recorded by a Datum Computer-Crntrolled Data-Acquisition System (Sect. 2.4).

The model is shown in Fig. 6 with the strain gages appiied but not completely wired. The three lines of zages in the fourth quadrant can be clearly seen. They are in the longitudinal plane at $0^{\circ}, 45^{\circ}$ from the longitudinal plane, and in the transverse plane at $90^{\circ}$ from the longitucinal plans. A closeup of the rosettes in the junction region is shown in Fig. 7 .

\subsection{Test Descrijuion}

Figure 8 shows the instrumented model in a loading frame being subjected to an in-plane momenti loading on the nozzle. The right end of the cylinder was rigidly clamped to the heavy flat plate using a split ring 


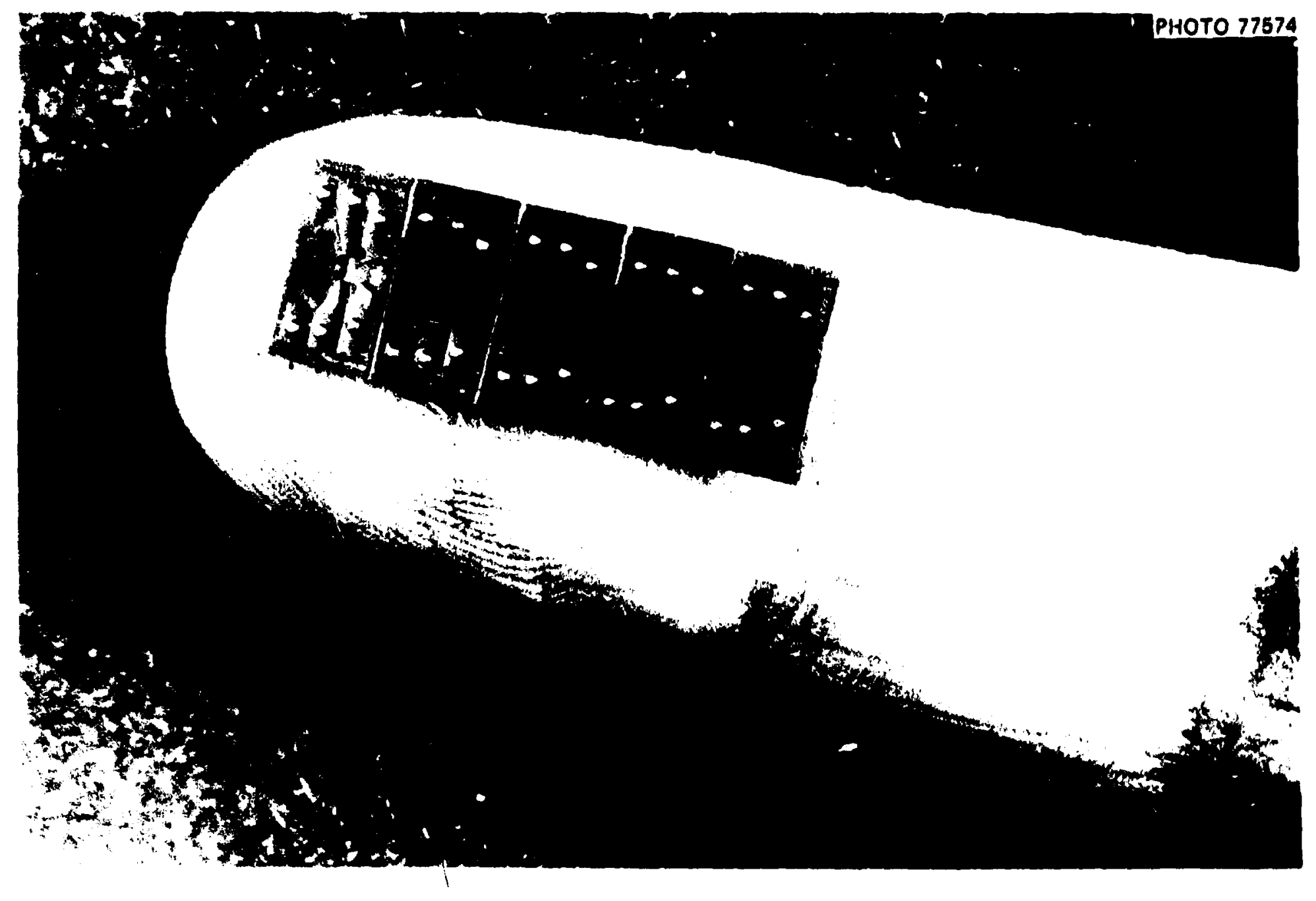

Fig. 5. Closeup of assembly of five strain-gage rosettes on a common foll backing. 


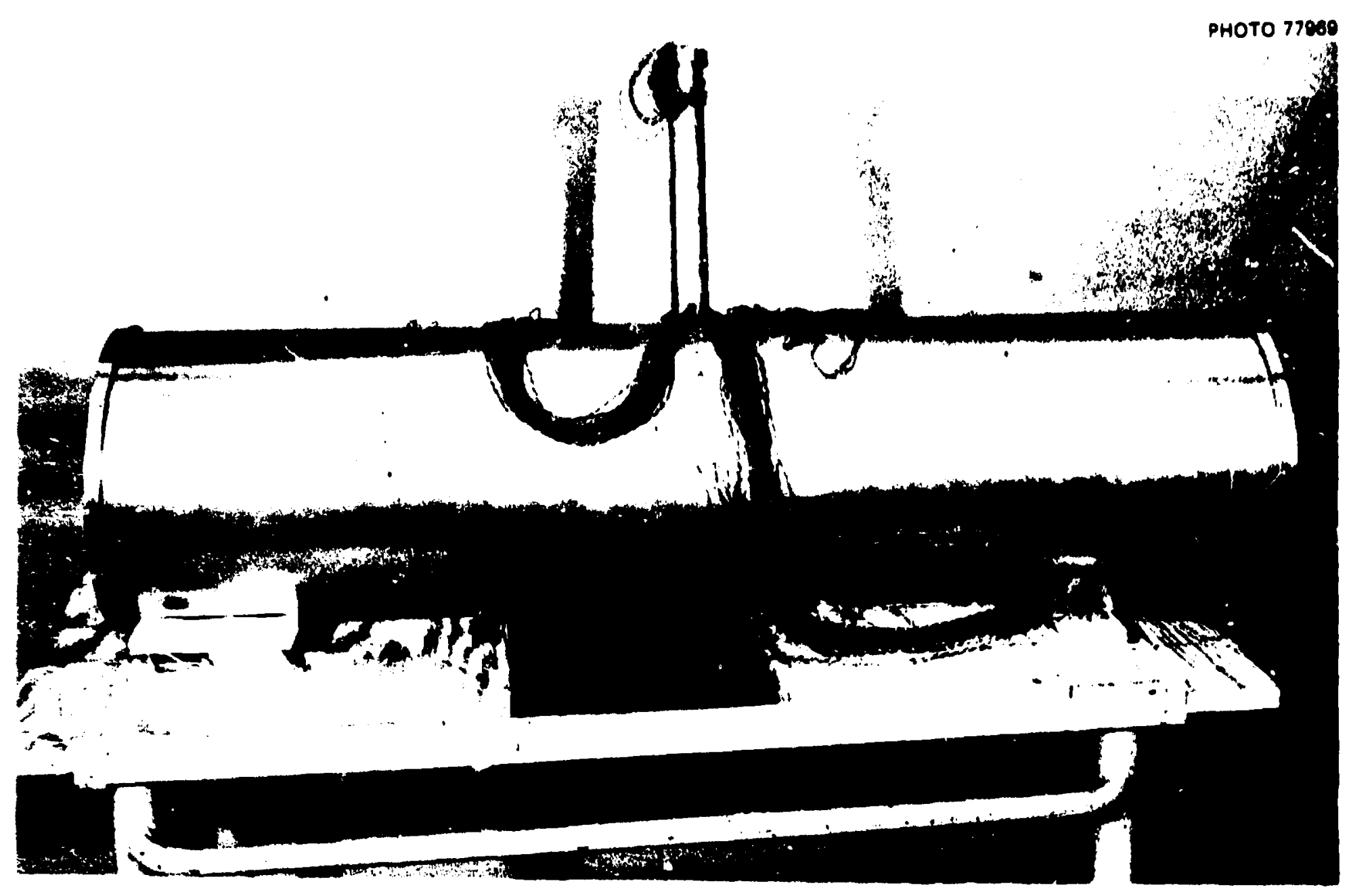

F18. 6. Model during instrumentation. 
$x$

$-$

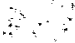

$-4$

$\therefore$

$+$

3

4

$\therefore$

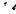

$-F \geqslant=$

$x$

$\frac{3}{300}=$

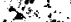

gito.

te $=$

列

.

it:

isto

is

ing

$\rightarrow+5$

政

.

in

.

if

A

nit?

th

5



3

i)

I)

$\alpha 5$
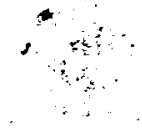


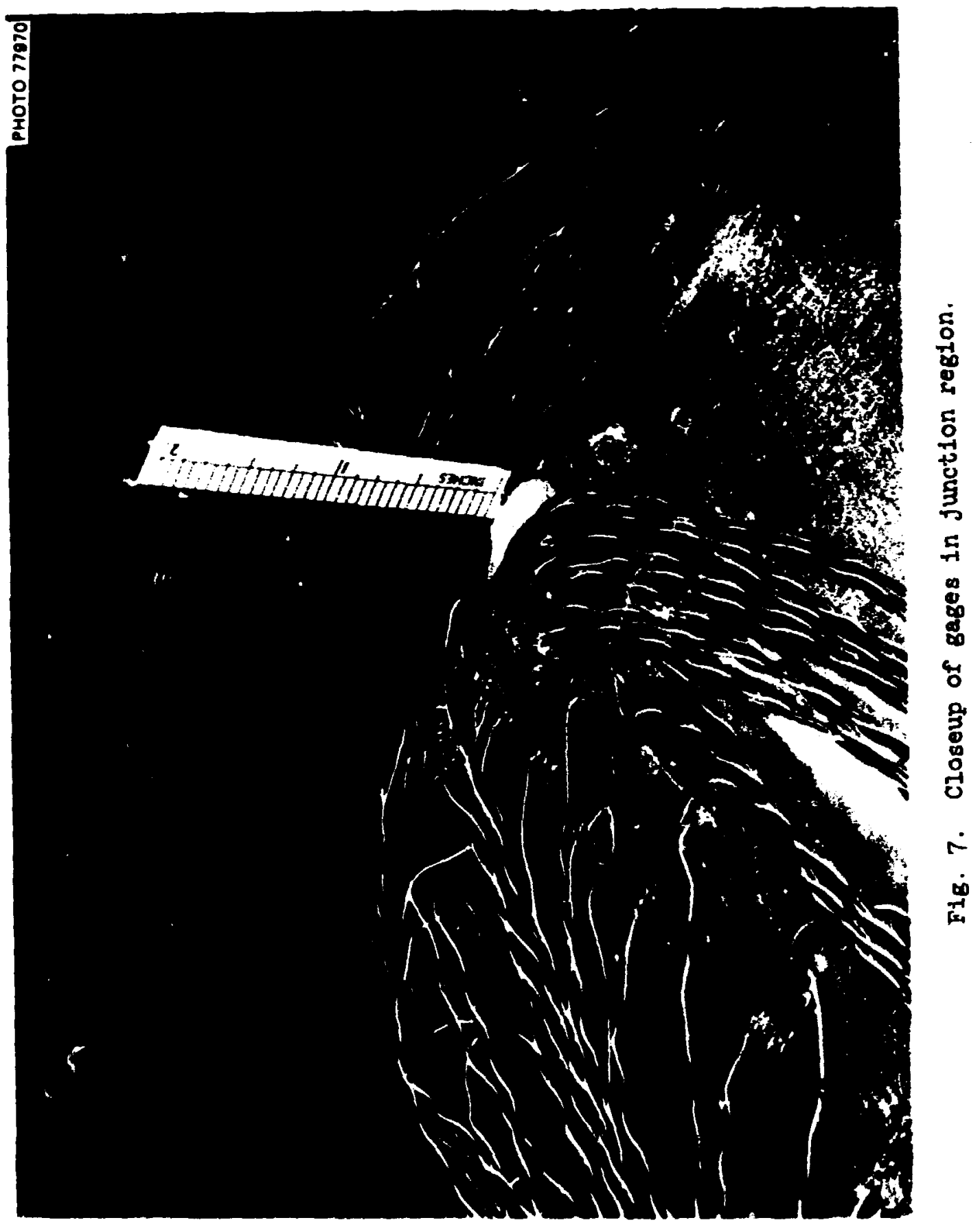




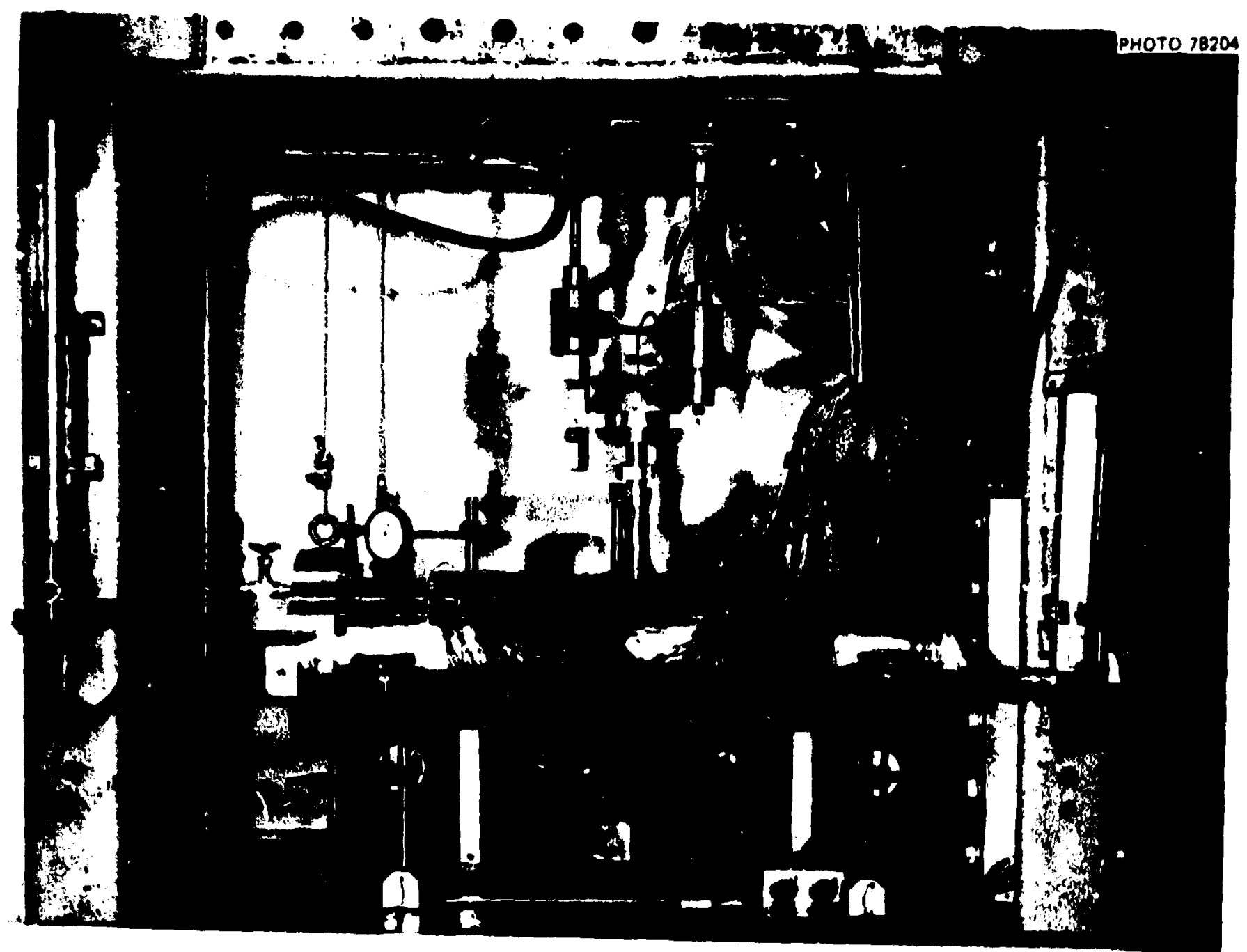

F1g. 8. Instrumented model in test frame being subjected to an inplane mament laading on the nozzle. 
arrangement acting over the flange on the end of the cylinder. The loading fixtures on the cther end of the cylinder and on the end of the nozzle were attached in a similar manner. The se heavy fixtlires in effect constrained the end circles of the shell to remain piane circles. The end fixtures were counterbalanced by weights attached to the cables (Fig. 8).

The external loads were applied by hydraulic rams acting through load cclls, and the loads were controlled by the load sell indications. The pressure loading was applied using a bydreulic fluid. To avoid undue straining of the molel, weights were used to counterbalance the weight of the pressurizing fluid in the model.

For all 13 loading cases, data were taken in eight steps. In most cases the data were taken at $0,25,50,75,100,100,50$, o\% of full load. The procedure was then repeated, so that two complete sets of data were taken for each gage every loading.

\subsection{Data Acquisition and Reduction}

The strain-gage data were recorded by a Datum Computer-Controlled Data-Acquisition System. The system consists of a data-acquisition unit composed of a data-acquisition control module controlled by a PDF- $8 / I$ cCEputer with the following capabilities: (1) magnetic tape input/output system, (2) in-core calculation ability, and (3) teletypewriter input and output.

The system records the strain data in millivolt readings on magnetic tape. The PDP-8/I computer converts the millivolt reading on the tape into engineering units (strains in this case) and stores them on a second tape which is compatible with the ORNL IBM 360-91 complter. This second tape is sent to the ORNL 360-91 computer, ard stresses are calclilated for each rosette by stripping the strains off the second tape.

The experimental results presented later in this report and tabulated in the appendix ar: generally based on the strain-gage readings at maximum load and on the first of the two sets of data taken from each gage and loading. If the first set of data was questionable for some reason, the second set was used. The strain-gage readings at fractional vulues of the maximum load were used to check Iinearity and drift of the gages. In cases 
wher nonlirearity or arift was excessive or where an indivi.?ual gage or circuit was itherwise obviously malfunctioning, the rosette of which the gage was a part was not used in the final results for the specific loadini case under consideration. In sane instances, a gage that sehaved erratically during one loading behaved nonally during others. Thus, in the final plots showing the experimental stresses, results fram a given rosette may be incluted for some loadings but not for others.

Stresses were calculated from the experimental strains by using a mcdulus of elasticity value of $30 \therefore 10^{\circ}$ psi and a joisson ratio of 0.3 .

\subsection{Variations of Haximum Measured Stresses Around Nozzle-Cylirder Junction}

In all cases, the maximum measured stresses occlirred at the nozzleto-cylirder junction. Cunsequently, in this section representative experimental results, in the form of maximum measured stress distributions around the nozzle-cylinder junction, are presented and discussed for each loading. Flots of all the experimental points along each gage line are presented in Thap. 4 for each loading and compared with theoretical predictions.

To examine the maximum stresses, stress ratios were considered. These ratios were determined by dividing the maximum absolute principal stress value at a point by a nominal memorane stress value. The membrane hoop stress in the cylinder and in the nozzle was used as the nominal stress level for the pressure loading. For tre moment loadings on the nozzle or cylinder, the maximum membrane bending stresses (computed by $M c / I$ ) or the membrane shear stress (computed by $T c, J$ and equal to the maximum normal stress) in the nozzle or cylinder were used as the nominal stresses. For the axial forces on the nozzle and rylinder, the axial membrane stress (calculated by $F / A$ ) was used. For the in-plane and out-of-plane forces on the nozzle, the nominal stress was somewhat arbitrarily chosen as the maximum bending stress in the nozzle (calculated by $\mathrm{Mc} / \mathrm{I}$ ) at the level of the top of the cylinder. For the in-plane and out-of-plane forces on the cylinder, the norinal stress was arbitrarily chosen as tha waximum bending stress in the cylinder at its midlengih (at the center lire of the nozzle). 
The applied loais used in the experivertal analyses are given in Table 1, together vith the romi:ul membrane stress levels calculated by the above frocediures.

Table 1. Afailer. loads and nominal stress levels

\begin{tabular}{|c|c|c|}
\hline Loading case & Load level & $\begin{array}{l}\text { Noninal } \\
\text { membrane stress } \\
\text { (psi) }\end{array}$ \\
\hline Internal pressure & 300 psi & 7,350 \\
\hline Git-of-plane mosent, $\mathrm{M}_{\mathrm{XI}}$ & 400 in. $-1 b$ & $5,3 x$ \\
\hline Torsional mawent, $\mathrm{H}_{\mathrm{Y}}$ & 1600 in.-10 & 10,590 \\
\hline In-plane moment, & +00 in. $-1 b$ & 5,300 \\
\hline In-plane force, $E_{X I}$ & $80 \mathrm{lb}$ & 10,060 \\
\hline Axial fo:ce, $F_{1 K}$ & 40016 & 1,620 \\
\hline aut-of-plane force, $F_{\mathrm{ZN}}$ & $60 \mathrm{2b}$ & 7,540 \\
\hline Torsional moment, ${ }_{X C}$ & 30,000 in. $-1 b$ & 990 \\
\hline Out-of-plane manent, MC $_{Y C}$ & $80, \infty 00$ in. -16 & 5,300 \\
\hline In-plane moment, $\mathrm{K}_{\mathrm{ZC}}$ & $80, \infty 00$ in. $-1 b$ & 5,300 \\
\hline Axiai force, $F_{X C}$ & $10,000 \quad 2 b$ & 1,620 \\
\hline In-plane force, $F_{Y C}$ & $30001 \mathrm{~b}$ & 3,800 \\
\hline out-of-plane force, $P_{\mathrm{ZC}}$ & $3000 \mathrm{Ib}$ & 3,880 \\
\hline
\end{tabular}

The variations in the experimentally determined maximum stresses around the nozzle-cylinder juncition are showr. In Figs. 9 through 21 for each of the 13 individual loading cases. In each case, the stresses shown were deternined fram the strain-gage rosettes immediately adjacent to the junction, and of the four possible maximum stress distributions - cylinder inside and outside ard nozzle inside and outside - those shown produced the largest stresses in each case.

The points labeled "extrapolated maximn" in the figures are estimated maximum stress ratios at the junction obtained by extrepolating the experimentally determined principal stress distributions along each gage line 


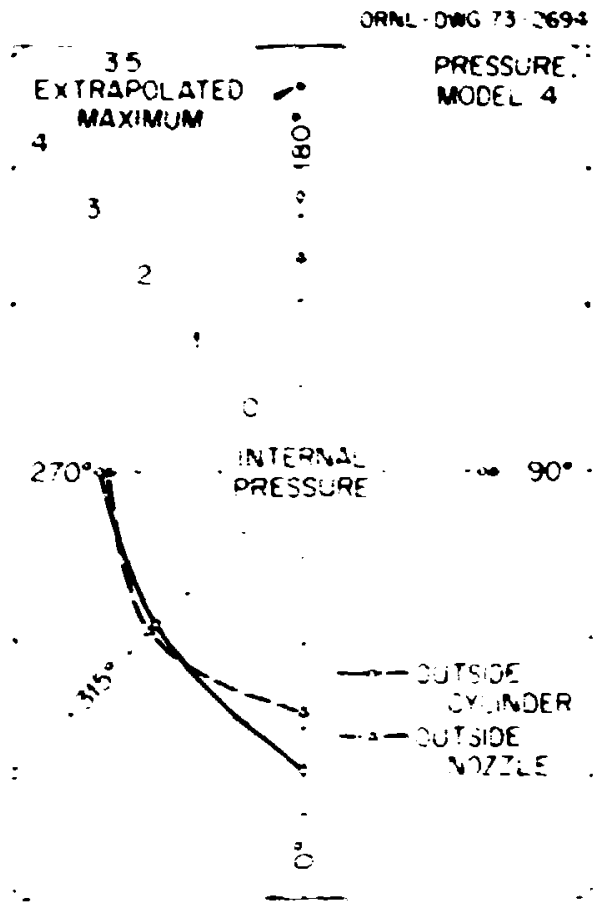

Fig. 9. Variation of maximum principel stress ratios elound the nozzle-cylinder junction for internal pressure.

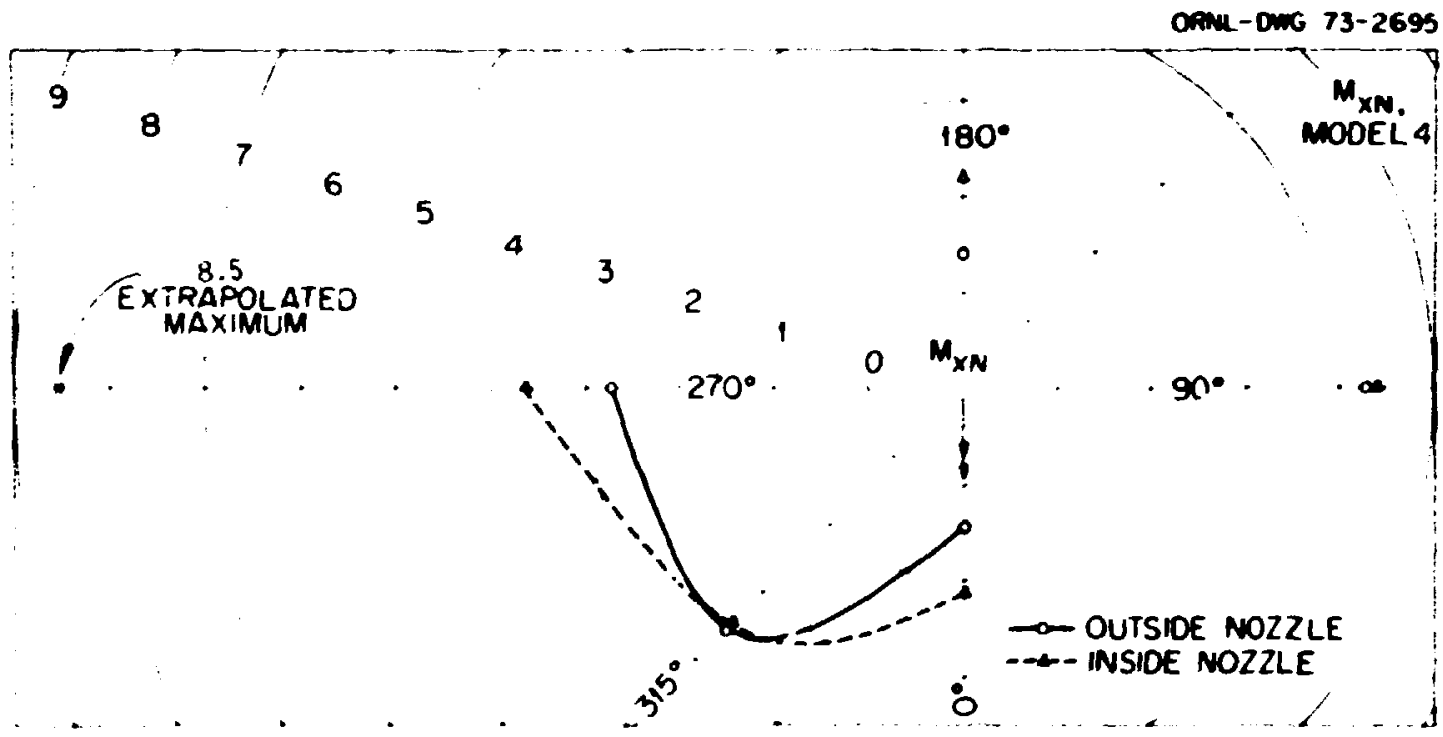

Fig. 10. Variatio. of mainum principal stress ratios around the nozzle-cylinder junction for out-of-plane moment, $M_{\mathrm{XN}}$ ' on nozzle. 


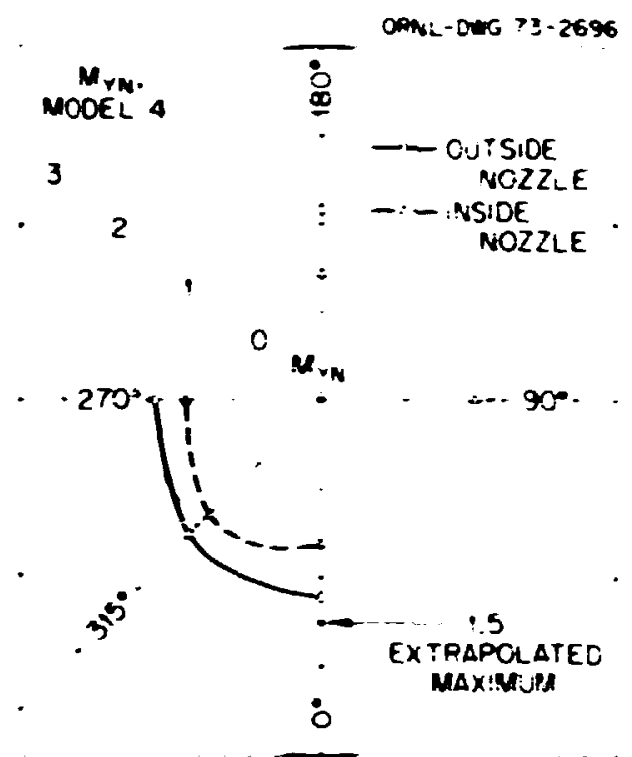

Fig. 11. Variation of maximum principal stress ratios around the nozzle-cylinder junction for torsional moment, "YN, on nozzle.
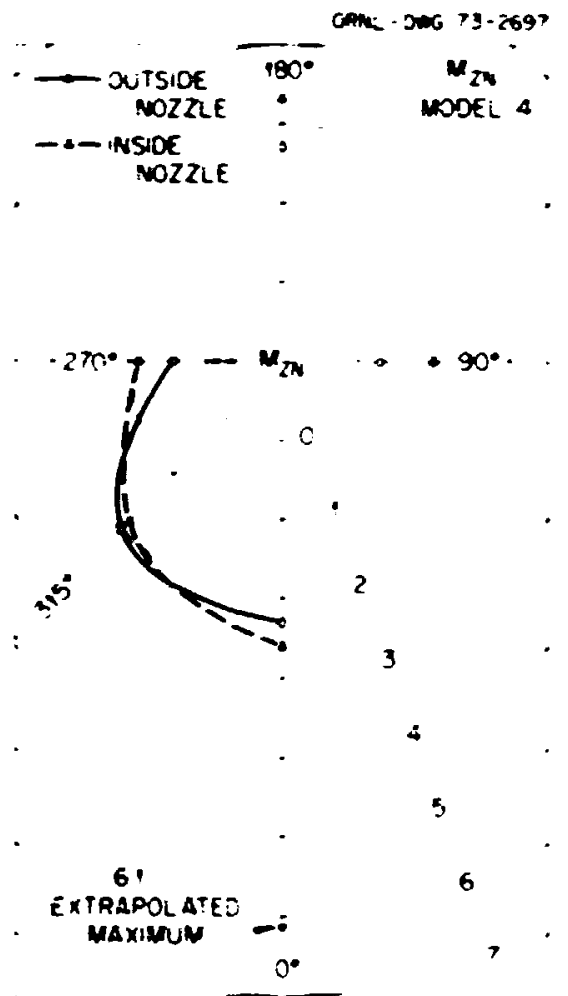

Pig. i2. Variation of maximu principal stress ratios around the nozzle-cylinder junction for in-plane mament, $M_{\mathrm{ZN}}$, on nozzle. 


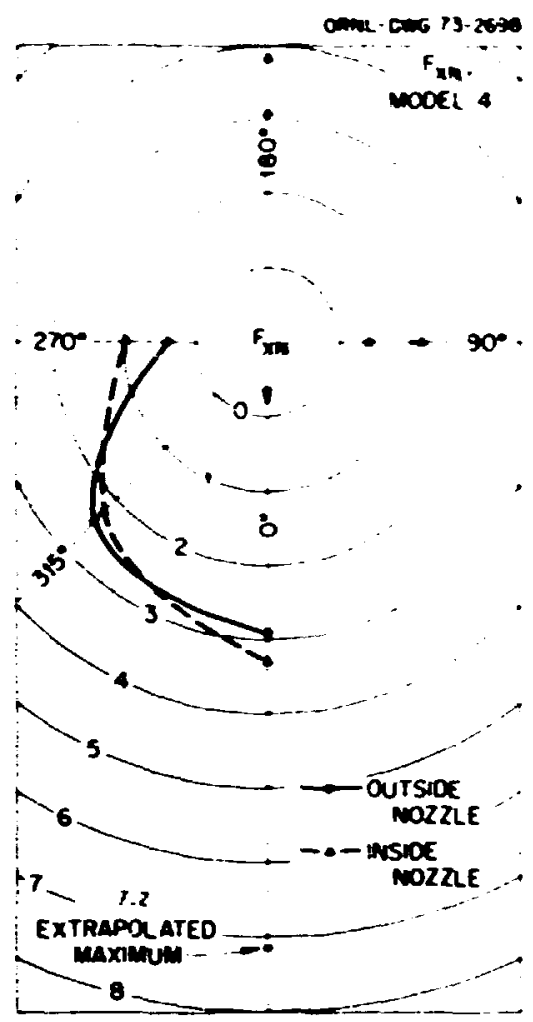

Fi6. 13. Variaticn of maximum principal stress ratios around the nozzle-cylinder junction for in-plane force, $F_{X W}$, on nozzle.

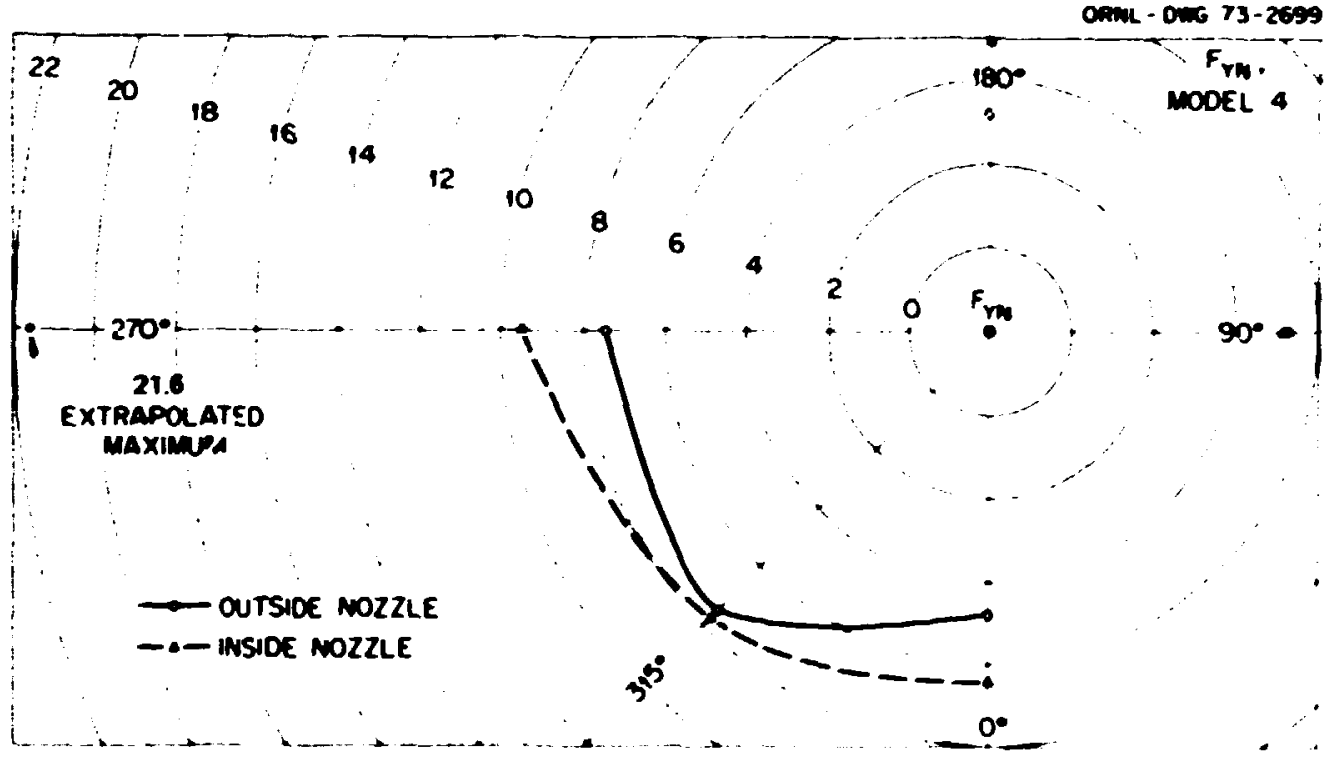

P18. 14. Varlation of mudmin principal stress ratios around the nozzle-cylinder function for adel force, $P_{Y}$, on nozzle. 


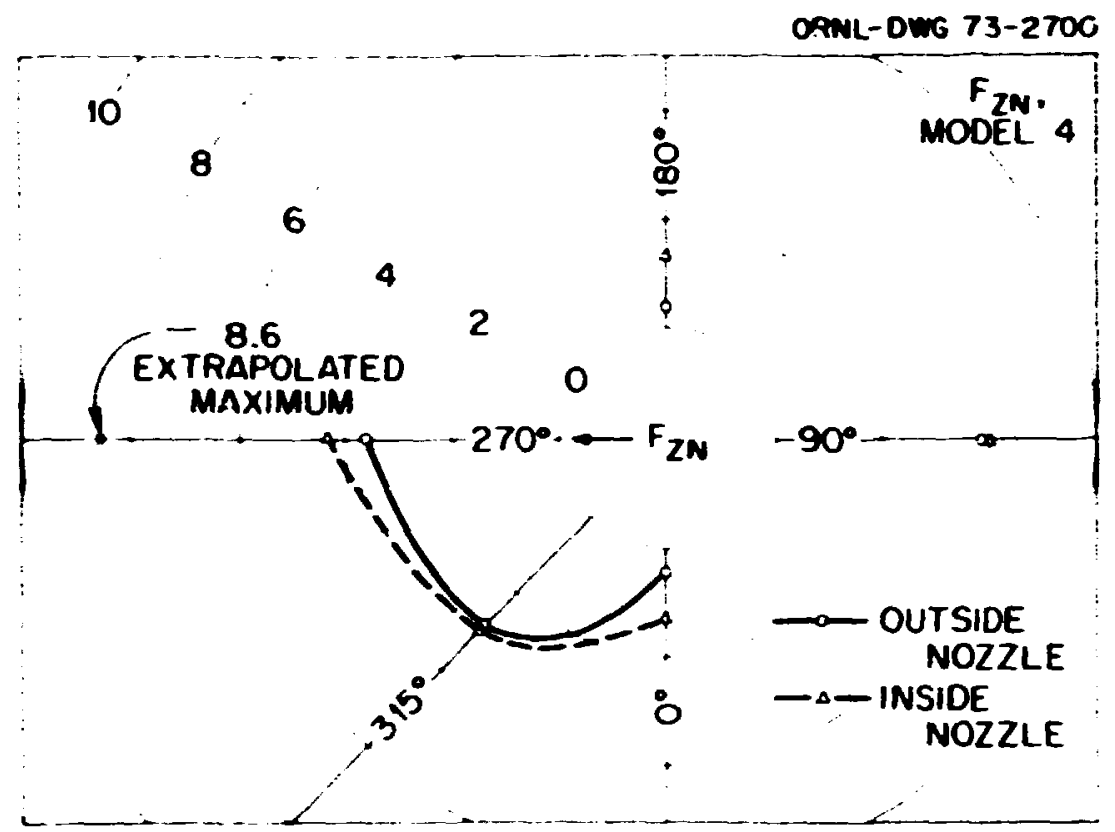

Fig. 15. Variation of maximen principal stress ratios around the nozzle-cylinder junction for out-of-plane force, $F_{Z N}$, on nozzle.

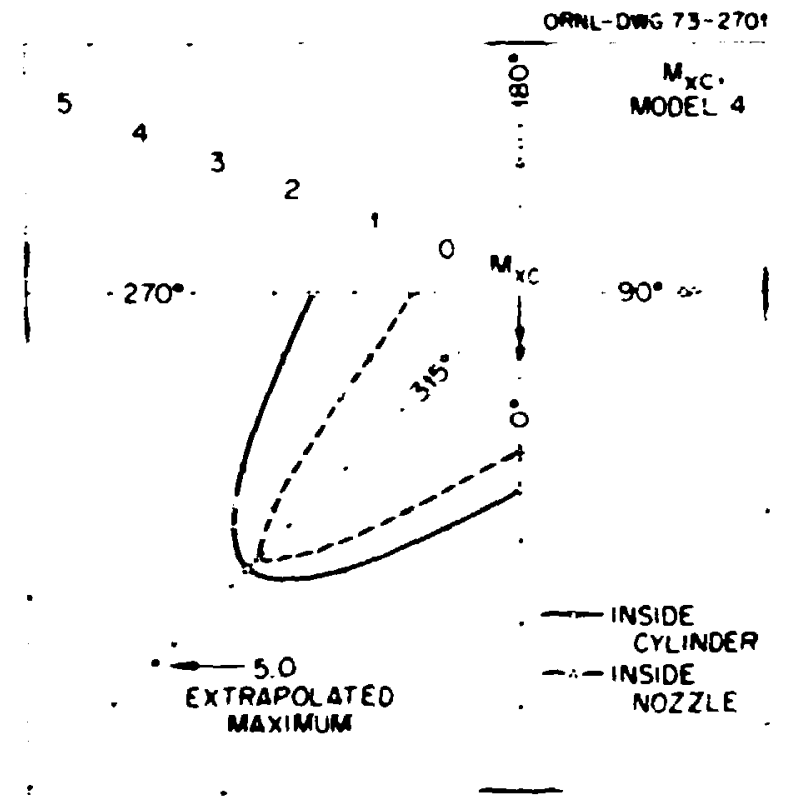

Fig. 16. Variation of maximum principal stress ratios around the nozzle-cylinder junction for torsional moment, ${ }_{X C}$ ' on cylinder. 


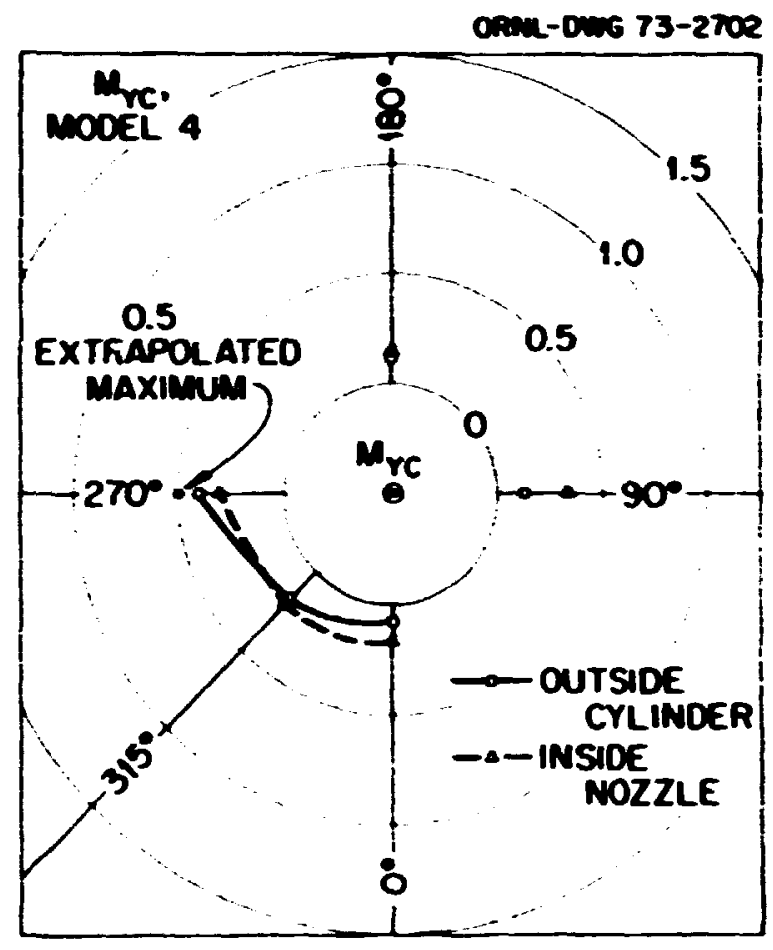

P18. 17. Variation of mxime principal stress ratios around the nozzle-sylinder function for out-or-plane wonent, My, on crlinder.

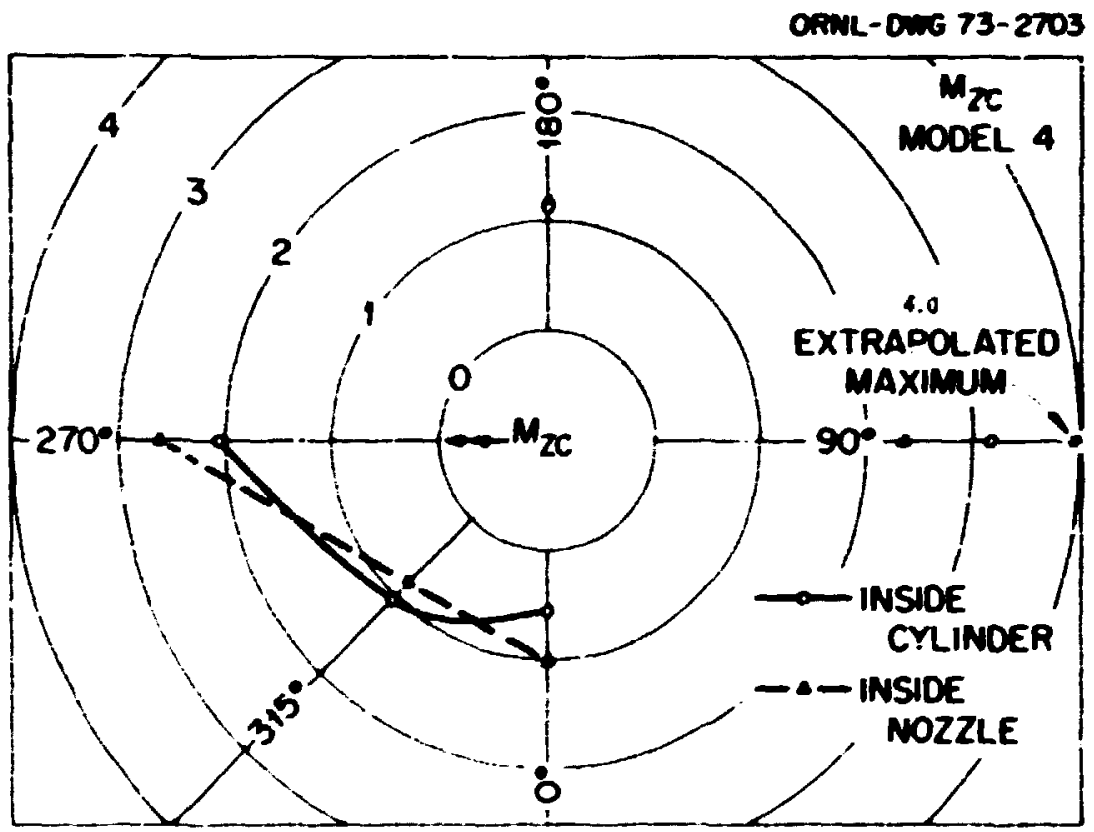

P16. 18. Vartation of maxian principal stress ratios around the nozzle-cylinder junction for in-plane monent, ${ }_{2}{ }^{\prime}$, on cylinder. 


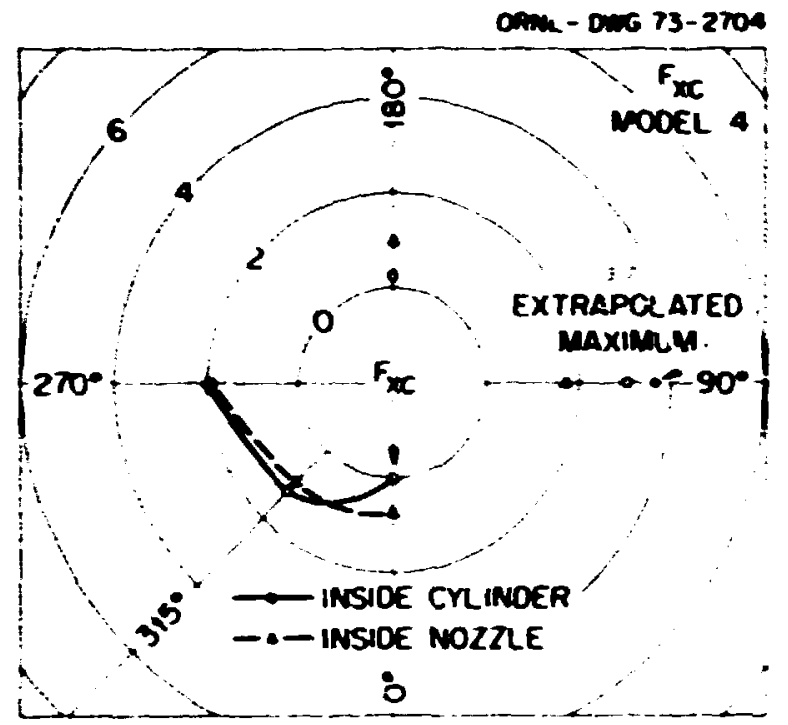

Fi8. 19. Variation of maimum principal stress ratios around the nozzle-cylinder junction for axial force, $F_{X C}$, on cylinder.

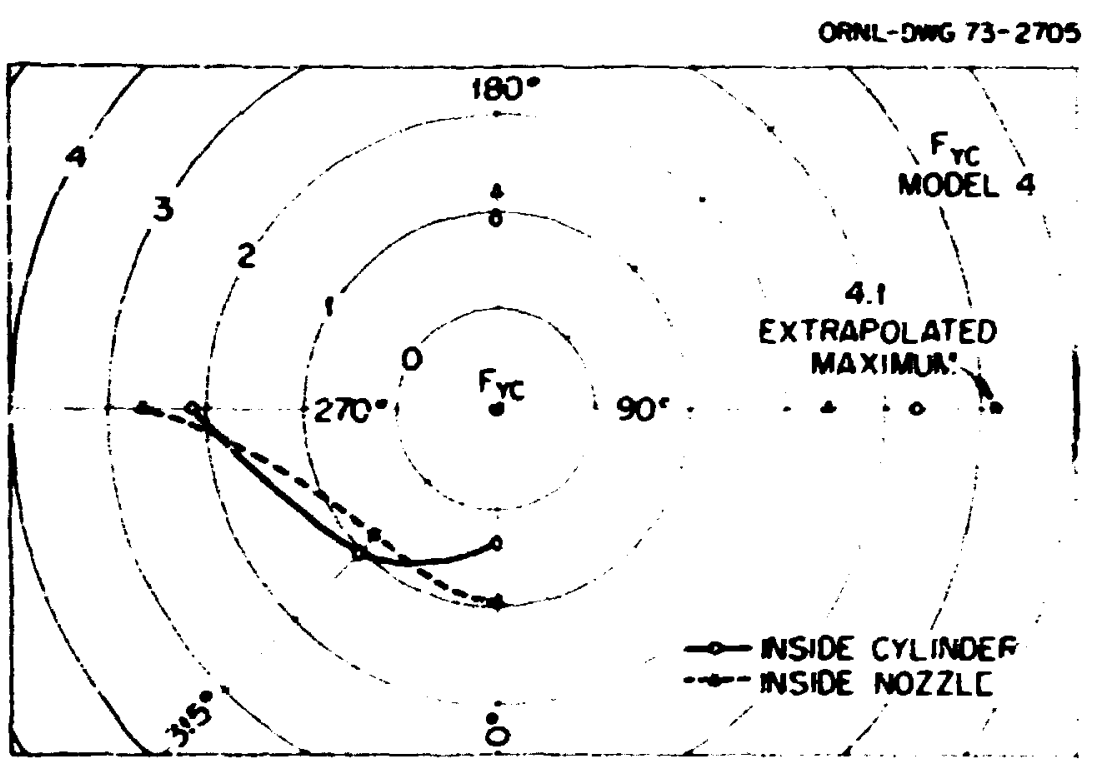

Ptg. 2 . Variation of maximin principel stress ratios around the nozzle-cylinder junction for in-plane force, $P_{Y C}$, on cylinder. 


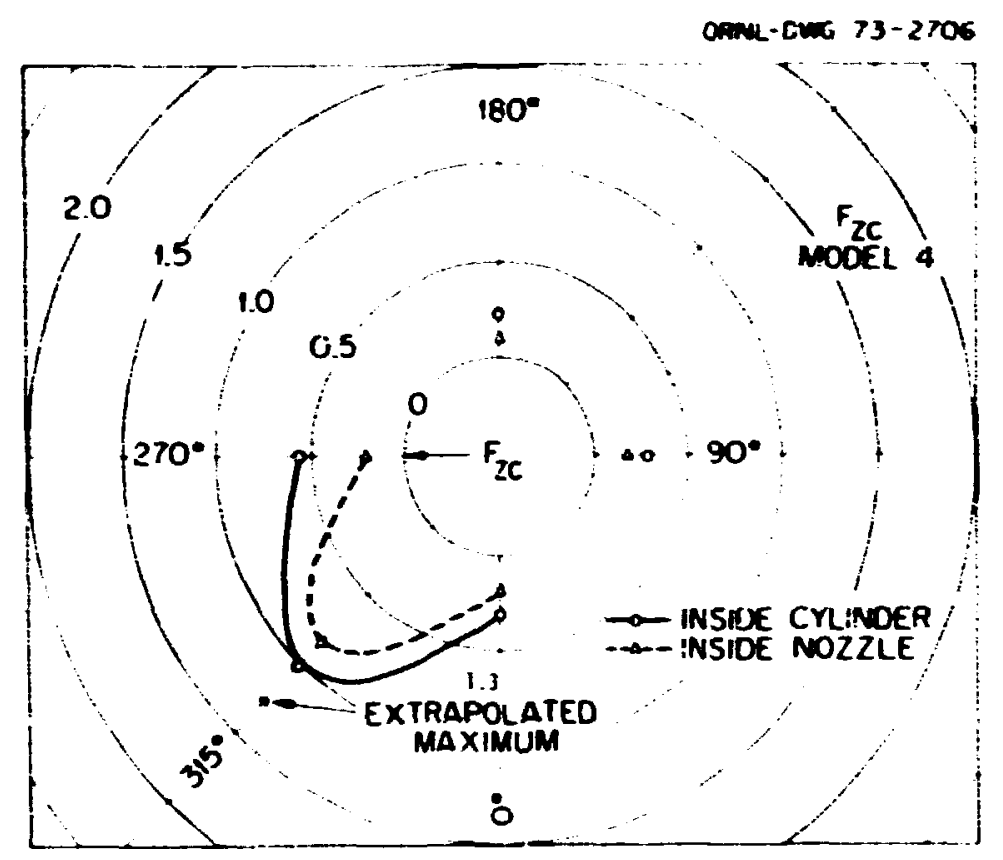

Fig. 21. Variation of maximum principal stress ratios around the rozzle-ylinder junction for out-of-plane force, $F_{\mathrm{ZC}}$, on cylinder.

to the peak stresses at the junction. It should be emphasized that the maxirum stress estimates are based on a consiaeration of the stresses along gage lines only; this does not preclude the existence of slightly higher stresses at locations between gage lines. The maximum stress ratios and the locations of the maximum stresses based on both the experimental and the finite-element analyses are tabulated and compared in Chap. 5.

Figures 9 through 21 indicate that, in general, the maximum measured stresses varied in a reasonably smooth and consistent manner around the nozzle-cylinder juriction. It is particularly significant to note that the maximum stress occurred in the longituainal plane of symmetry only for the Internal pressure case, in-plane force and moment, and torsional moment on the nozzle. For all other loadings, the maximum occurred in the transverse plane of symnetry or at an intermediate position between the two planes of symetry. 


\section{FIT ITE-EIDGES AMLYSIS}

\subsection{Beckround}

Thin-shell cylinder-to-cylinder intersection probleas have, in recent years, been a favorite with the stress analyst. Their popularity stens not only frea the canmon occurrence of such configurations in prectical design, but also from the challenge that they present es complex shell analysis problens. In addition to their use in piping and pressure vessel conNigurations, thin-shell cylinder-to-cylinder intersections secur in the petrolec industry, which uses tubular structural wanbers extensively in off-shore oil-drilling towers. Much of the cylinder-to-cylinder intersection research, both experimental and thearetical, that has been done was motivated by the off-shore oil-drilling torer application. 9

Both analytical and muerical analyses have been developed and applied to thin-shell cylinder-to-cylinder intersection probleas. In 1961, Reidelbech $^{10}$ developed the first analytical solution for two perpendicularly intersecting cylindrical shells subjected to internal pressure. Eringen ${ }^{1-14}$ and his so-workers corrected some errors and approximations in Reidelbach's solutions and formulated a solution in wich the intersection curve was approximated by a circle. These solutions consisted of prodwets of Krylor functions and Hankel functions of the first kind. A collocation method was used wereby the boundary conditions were satisfied in a least-squares sense at selected boundary points.

In 1\%69, Hansberry and Jones ${ }^{15}$ used the method developed by Re'delbach and Eringen et al. to develcp a solution for an in-plane bending moment applied to the nozzle of a nozzle-to-cylinder configuration. In 1970, Maye and Eringen ${ }^{26}$ developed a solution using Fourier series involving Bessel functions in place of the Krylor functions. In 1973, Hansberry and Jones $^{17}$ expanded their solution to include the case of an axial force applied to the nozzle. As in the case of earlier solutions, however, the nozzle diameter was limited relative to the cylinder diameter.

In 1367, Bijlaard, Dohmann. and Wang ${ }^{18}$ formulated the problem to include the case where the nozzle and cylinder are of equal diameter. They indicated a snintion in the form given by Flïge for closed cylindrical 
shells. In 1969, $\operatorname{Pan}^{19}$ develoged a merical solution to the differential equations of Fïrse and Donnell that is applicable to the equal-dianeter case. He copared his preaictions with the experinextal results obtained

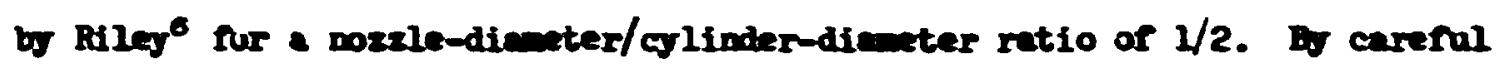
cholce of scre of the fectors used in the solution, he obtainad predictions that apreed reasombly well with experinent.

In 1968, lierwonn and Combell 20 presented a finite-elenent sbell anclysis formultion using flat-plate elewents, and as a saple jroble thy ured the $1 / 2$ dimeter ratio model tested bo Riley. ' The linited conparisons shown were for int3rnal pressure and indicated reasonbly good areesent between theory and experinent. In 1969, Prince and Pashid ${ }^{21}$ also presented a Nat-plate finite-elenent shell analysis and used the crlinderto-cylinder intersection as a saple problen. Their shell analysis progran vas developed under subcontract to Oful as a part of the ORIL Prestressed Concrete Reactor Vessel Progran.

\subsection{Finite-Element Method}

The finite-element program used for the analysis of this model was chosen as being reasonably representative of currently arailable and widely used finite-element shell formulations. The program ws developed at the University of California, serteley, under the direction of Professor R. $H$. Clough. The original program was written for general shell analysis by Johnson 22,23 and was later modified and adopted by Greste ${ }^{9,24}$ for trexting the " $K$ " joints of cylindricel shells found in off-shore ofl-drilling towers.

The basic elements used in the program, shown in Pig. 22, are nonplenar quadrilaterals that are built up of an essemblege of four component triangles as show. Within each couponest, triangle, the in-plane displacements $u$ and $v$ are assumed to vary guadratically over the plane of the triangle, except that they are constrained to vary linearly along the one exterior edge. The resulting membrane element, referred to as a conatrained linear strain triangle (CLST), has two degrees of freedom ( $u$ and $v$ ) at each of the five nodes. 


\section{(REPRESENTED OY QUAURILATERAL ELEMENTS)}

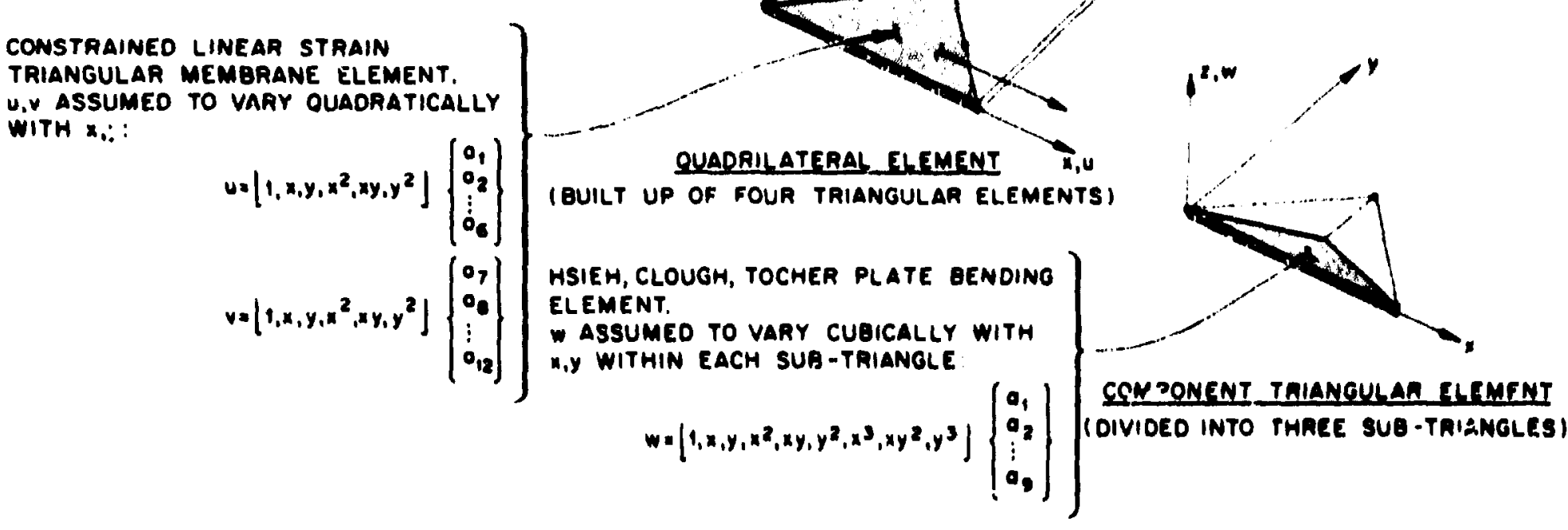

Fig. 22. Qundrilateral eloment and component triangles. 
The plate bending portion of the component triangle elements has three degrees of freedon at each of the three corner nodes - two rotations about axes in the plane of the eleneat and the transverse, or nonal, displacenent $w$. The displacenent expension for this elenent is dye to Hsieh, Clough, and Tocher, 25 and the element is referred to as the HCT triangle. Full coupatibility of displacenents and slopes between triangular elenent boundaries is achieved by dividing the elenent into three subtriangles and essining an indegendent cubic variation for $w$ within each subtriangle. One of the ter terms of the general cubic is neglected in each subtriangle, so that in the final assenbled component triangle the normal slope varies 15nearly along each exterior edge. It is this feature that ensures slope comatibility in the resulting elenent systen for plate bending probleas. The 27 constants in the three cubic expressions for $w$ within the trianguIar element are rectuced to 9 (and related to the 9 nodal degrees of freedom) by internal compatibility consiaerations. Hith $w$ varying as a cublc polynomial vithin each subtriangle, the three casponents of curvature, and hence the bending and twisting moments, vary linearly.

The total stiffness (membrane plus tending) of the triangular elements that for the components of the quadrilateral is obtained by superposition of the plate bending elenent and the membrane elenent. The meabrane plus bending stresses vary piecerise linearly over the surface of the resulting triangular element.

The quadrilateral eleaent stiffness is obtained from that of the four component triangles. In generel, due to the curvature of the shell that is being discretized, ar arbitrary quadrilateral will be nomplanar. This introduces a complication in the transformation of the triangular element stiffness, because on the element level only two bending rotations per node are defined. When transformed from the element coordinates to sone other coordinate system, a third bending thation quantity is introduced, and in the transformed system three rotational degrees of freedan should be considered at each node. This consideration regarding the third rotational degree of freedom also arises in the subsequent assenbly of the quadrilateral elenents into the total structural stiffness, since adjacent elenents are generally not coplanar. In his formulation, Johnson 22 chose to retain only two rotations per node in the total element assemblage. He argued 
that since the element plane in a surficiently fine mesh lies close to the stell tangent plane at each node, the rotations could be trensformed rran the elesent coordinates (in the plane of the elenent) to coordinates in the shell tangent plane and the sall transformed coponent of bending rotation about the nornal to the shell could be neglected. Mis is perhaps a reascable assugtion evergubere except at the junction of intersecting shells.

The stiffness formation for the quadrilateral elenent, as vell as for the CLSI me-brene element and the HCr plate bending element, is sunarized by Greste. ${ }^{3}$ The quadrilateral element has five degrees of freedon at each node: $u, v, l$, and the two rotations. In the finl assembled structure, the five degrees of freeda per node are $u, v, v$, and the two rotations about the st.eil tangent coordinates at each node.

The task of the finite-elesent nethod is to detenine the unknown coefficients of the assuned element displacenent functions for $u, v$, and y. This is done by connecting the quadrilateral eleaents at discrete points, the corner nodes, and requiring competibility of displacenents and rotations and equilibriu of forces and woments at these nodes. Unfortunately, wen the elenents are ssseabled into a curved-shell structure, compatibility and equilibriv are not capletely achieved along the elenent interfaces. Thus there are inherent sall errors involved. However, studies by Johnson 22 bave shown that these errors are not too significant provided a sufficientiv fine elesent wesh is used.

There is an error in intersecting shell problens which is not diminiched by mesh refinement. This error arises from the aforenentioned neglect of the rotation about the shell noimal. At the junction nodes in the cylinder-to-cylinder intersection probles, there are three nonzero rotational components, but only two of these can be retained as nodal degrees of freeda. Greste ${ }^{9}$ chose to define the tangent plane, and hence the two rotational degrees of freedan, at the junction rodes as the cylinder tangent plane. The manner in wich he treated the junction nodes thus constrained the normal rutation about the cylindrical shell normal to be zero at the function. This rotat!onal constraint unrealistically constrains the bending deformation of the adfacent nozzle elements. 
This constraint did not greatly affect the analysis of nodel 1 , but its erfect was significant in the analysis of nodel 4. A problen arose in the aneirsis of model 4, with its sall' slender nozzle, that was not encountered in the analysis of wodel 1 or in similar Eodels vith relatively large nozzles. In the cases of the in-plane and out-of-plane forces and nants applied to the end of the nozzle, it was found that the memranetype axial bending stresses, which should have been constant along the nozzle, were dissipated with distance from the end of the nozzle. This dissipation was traced to the neglect of the rotational degree of freedom about normals to the nozzle surface and occurred in model 4 because of the relatively large deformations of the sall slender nozzle. This problem was orercane by rederining the neglected sixth degree of freedan for these londing cases.

The difficulty is illustrated by the exaple problen shown in Fif. 23, in which the nozzle of nodel 3 was analyzed by fixing a row of nocies near the junction. ${ }^{2}$ The mesh shown in Fig. 24 for the nozzle was used, and the nozzle vas subjected to a bending monent at the free end. The distribution of normalized bending stress in the outer wall of the nozzle is shown for three different analyses. Also shown is the predicted stress based on simple beam theory with $I=\pi^{3} \mathrm{~h}$ and $c=a$, where $a$ is the radius of the midsurface and $\mathrm{h}$ is the nozzle thickness.

The middle curve in Fig. 23 was obtained with the camponent of bendIn rotation about normals to the nozzle surface neglecter. These neglected rotations are small and are in effect set to zero in the assembled set of equations. Orerall equilibrium implicitly requirss that sall moments be impsed at each node to maintaln zero bending rotation. These anall constraints combine to counteract a portion of the applied monent and result in the decrease in membre bending stress depicted in Fig. 23. To illustrate that these nodal constraints depend on the deflection of the nozzle, the problem was reexamined using a reduced elastic modulus for a section near the fixed end. The nozzle denection produced by the applied mosent was thus increased, and the bending mowent was dissipated more repidly as shown by the left-hand curve in Fig. 23.

The problem was overcome by redefining the neglected degree of freedom in the ncazle. ${ }^{2}$ Rather than setting the rotations about normals equal 


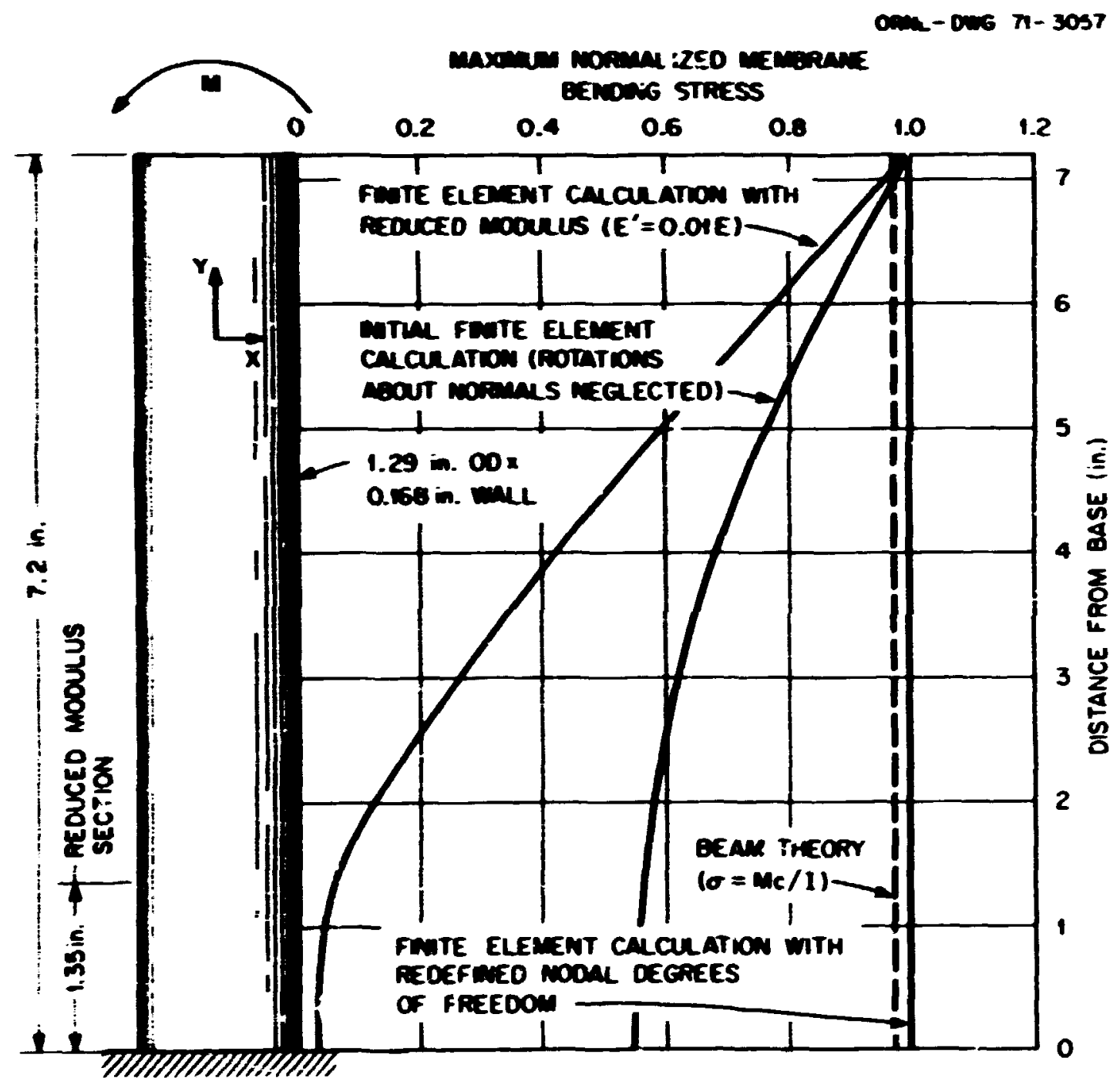

Pig. 23. Danple problen demonstrating effects of neglecting the component of bending rotation about normis to the surface of a small slender nozzle.

to zero, the rotations ahout lines parallel to the nozzle axis were set equal to zero in the final assembled set of equations. The assumption of zero bending rotation about lines parallel to the nozzle axis is a reasonable one and is equivalent to the assumptic:l, often made in analyzing the local bending in cylindrical shells, that changes in curvature in the hoop direction are negligible compared with those in the axiai direction. Balley and Hicks, 20 for exapple, made the latter assumption in examining 
the efrects of a bending ant applied to the nozzle of a nozzle-to-spher ical-shell attachent. With this modirication, the eabrane bending moment reained constant, as shown by the right-hand curve in Fig. 23. This modification was used in the analysis of the in-plane and out-or-plane forces ard morents on the nozzle.

In conilusion, two significant points should be mile. First, even though a computer progran wy be checked for sane geonetries and conditions, there can be other cases for which it does not runction properly. Thus, structural analysis progrens must be thoroughly validated for the range of paraneters over which they are expected tc apply. Second, the probleans introduced by considering only five degrees of freedan per node could be eliminated by retaining six degrees of freedom in the final assembled equations. However, for large systems, the five degrees of freedan per node has a distinct advantage from the standpoint of economy of computer time.

\subsection{Finite-Element Idealization of Model}

The fizite-element representation chosen for model 4 is depicted in Fig. 24, which shows developed views of one-half of the nozzle, cylinder, and end plates. It was necessary to consider only one-inalf of the structure because of symetry considerations. This mesh layout was developed manually and was arranged so that lines of noies corresponded to the lines of strain gages in the experimental model. There were 993 nodes, resulting in approximatelir 4500 linear algebraic simultaneous equations to be solved for the unknown displacement parameters. There were 25 nodes along the (half) junction line between the nozzle and cylinder. AII 13 loading cases considered experimentally were analyzed using this mesh, and the theoretical predictions were compared with the experimentally determined stresses (Chap. 4).

Seven of the 13 loadings - pressure, axial forces on cylinder and nozzle, and in-plane moments and forces on cylinder and nozzle - produce behavior that is theoretically symmetric about the longitidinal plane of symmetry of the model. For these symmetric losdings, it is correct to consider just one-half of the model in the finite-element representation. The 


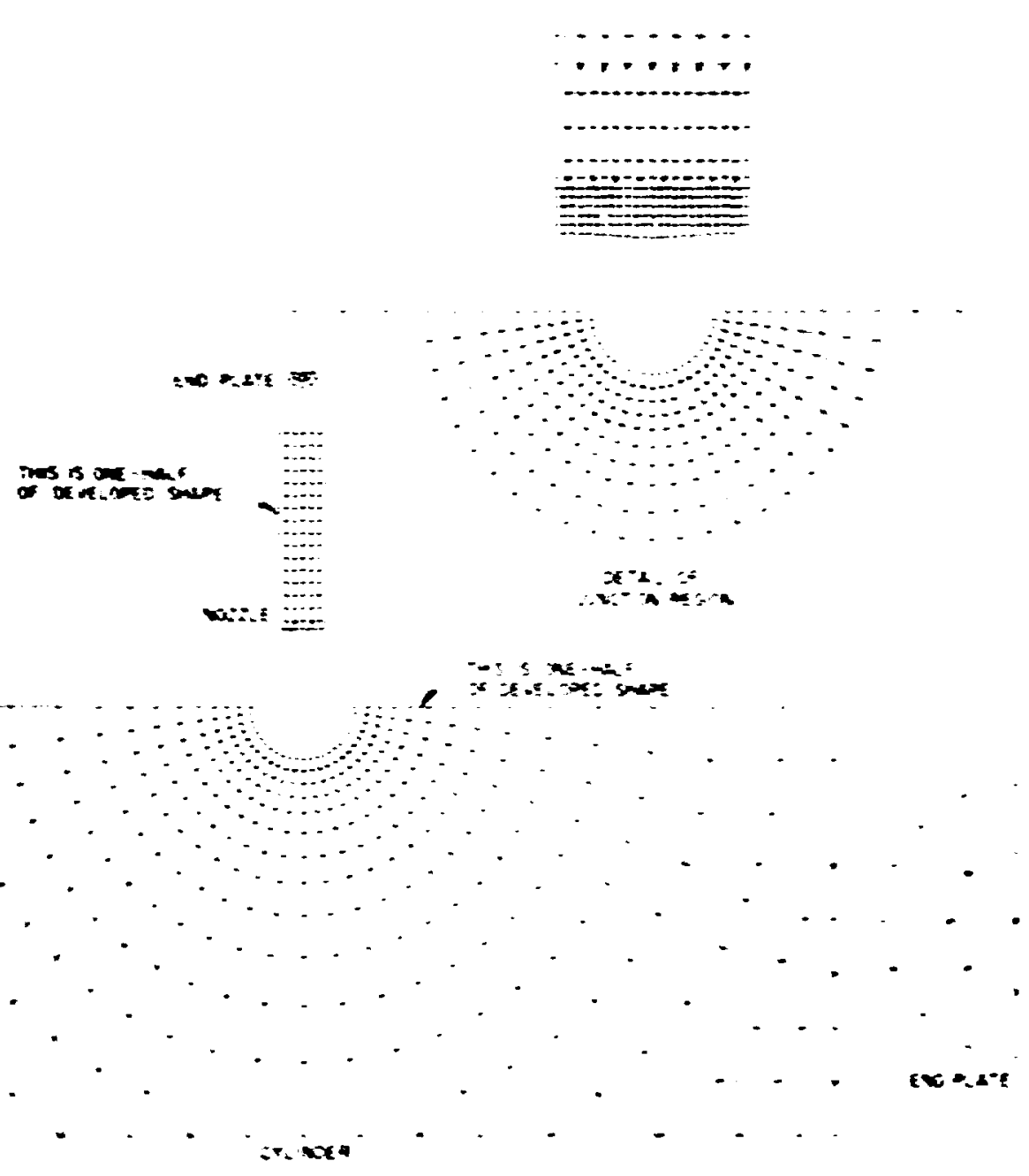

P:8. 24. Finite-element idealization of mode1 4.

boundary conditions on nodal displacements and rotations are those comoniy associated with sywetry conditions.

For the remainifg six loadings - out-of-plane moents and forces on cylinder and nozzle and torsional moments on cylinder and nozzle - asymmetric conditions exist, and to consider just one-half of the model in the finite-element representation requires assumptions or approximations in establishing nodal displacement and rotational boundary conditions. Basically, the boundary conditions used were based on the assumption that the pi ojection on the X-Y plane (see Fig. 2) of the boundary reanined fixed in 
the X-Y plane. In other virds, the displacenents in the $X$ and $Y$ directions and the rotation about the $\mathrm{Z}$ axis were assunel to be sero for the nodes aloag the boundary in the X-I plane. Although these conditions are obviously sot strictly correct, they nonetheless seem to be reasonable assumptions that are userul for reducing the size of the problea to be solved.

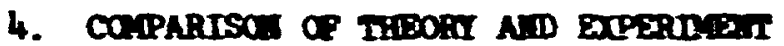

The theoretical predictions, based on the finite-element lavout shorm in Fig. 24, are copared in this chapter vith experinentally detenined distributions for all 13 landing cases. For each loading, the theoretical and experimental stiess distributions along the five gage lines on the cylinder and nozzle (see Figs. 3 and 4) are presented. The stresses shown $a r=a l w y s$ those perallel (loagitudinal) to the gage lines and those perpendicular (transverse) to the gage lines.

\subsection{Internal Fressure}

The measured and predicted stress distributions deternined for an internal pressure of 300 psi applied to the model are show in Pigs. 25 through 29. Figure 25 shows the seasured and predicted stress distributions on the outside and inside suraces of the cylinder and on the outside and inside surfaces of the nozzle along the $0^{c}$ gage line, which is the longitudinal plare of symatry (see Figs. 3 and 4). The stresses are shown as a function of distance frow the junction of nozzle and cylinder midsurfaces. The hearg lines are the predicted stresses, wille the fine lines through the experimental points show the measured distributions. The solid lines in each case represent the transverse stresses, which are perpendicular to the gage lines. The dashed lines represent the longitudinal stresses, wich are parallel to the gage lines. Thus, we can compare the solid lines with each other and the dashed lines with each other.

The agreentrit between theory aind experiment is good in Pig. 25, except that the stresses at the junction, which is where the maxioun occurs, are at times underestimated sonewtat by the finite-2lement predictions. 
Howerer, the geveral shope and distributions of the stresses are veil predicted by the theary.

Pigures 26 throuk 29 are arranged to recilitate read conparison of conpable results. Figure 26 shours the stresses alog the 180" obe line, Wich is opposite the $0^{\circ}$ doe line in the londitudinal plane of asuetry. Because of ambetry, the stresses along the $180^{\circ}$ fore line are elnost the

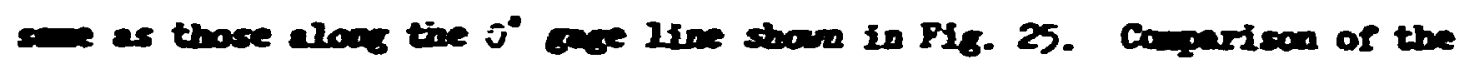
two figres shours eucelleat agsenent between results for oposite sides of the nocerle in the langitudinal plane of symatrs.

The realts for a goe line $45^{\circ}$ nen the lodgitudinal plane of annety (sec Plos. 3 and 4) are show in PI8. 27. Figure 27 shous the results for the $315^{\circ}$ gove line, which is in the fouth gratant. Abresent between theor and eqperitent is not as good bere as for the previons two figures. Fote in particular the lare disoppeeneut in the shape of the ceavured and predicted stresces on the inder surfece of the cilinder.

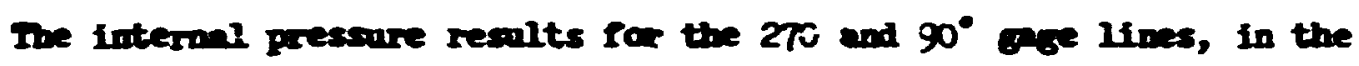
tranderse plane of shmetry, are shown in Figs. 28 and 29 respectively. Here the sareanent between theors and expexineat is not as good on the transverse plane as aloag the longitudinal plane; bovever, since the stresses are 10w, the disagreenent is perthyps Lot too stemificant. The overall apresent setween theory and experinent is generelly eood.

The nothod uned to deterine the estinated maina experinental stresses and streas ratios ves described in Sect. 2.5. The naxim theoreticall prealcted stresses were obtained in the sone naner; that is, the vere talen as the largest absolute values of the principal stresses. To wtch the experineutal nxims, the search for the theoretial madwase ve linted to goge lines onj.

The endive experinemtally deternined stress occurred on the inside surface of the cylindex at $180^{\circ}$, and the maitin stress ratio ws 3.5 . The theoretical andion stres wa on the outer surrase of the possle at $0^{\circ}$; the endion streas ratio we 3.1 . 


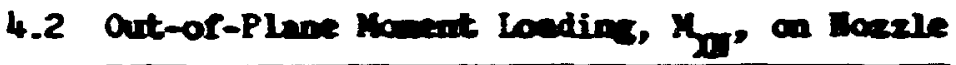

The measured and prodicted stress distributions for an out-of-plone cont loading of 400 in.-16 epplied to the noeste of the wel are shan in Ifos. 30 through 34. Desults for the Nive oro lines are arrenged in the sue saner as for the internel pressure case, although the fouth and secood quadrant results sre wot, in this case, theoretically the sone.

The results in Fifs. 30 and 31 are for 0 ad 189", respectively, in the loxgitudinal plane of symetry. As expected, the stresses are sall, since these locetions are somente andopous to the neutral aris of a been in bending. The results for the $315^{\circ}$ are lixe, which is $45^{\circ}$ fro the longitudion plese of symetry, are shim in Fif. 32. At this location the stresses are larger, and the agreenent between theory and experiment is very good.

The results for the 270 and $90^{\circ}$ Tge lines, which are ioceted in the transrerse pine of symetry, are shown in Fios. 33 and 34 respectively. Here, the stresses are a maim on the transverse plane, and the agreewent between theory and experient is very bood. The maximan experimental stress is on the inner surface of the nozzle and is closely predicted by the andysis.

The madran experinentally leternined principal stress ratio wes 3.5, irth the eacimas stress occurrife on the inner surfece of the nozwle at the junction on the $270^{2}$ gege line. The theoretial animu was on the outer surface of the joxxle at the junction on the $270^{\circ}$ gage line, and the maxim stress ratio was 7.6.

\subsection{Torsional toonent Loading, Hn, or Itozzle}

The seasured and pzedicted stress distributions for a torsional nonent landing of $1500 \mathrm{in.}$-ib epplfed to the sozzle of the model are stours In Figs. 35 throung 39. is in the previous case, the fourth and second guadrant results are not theoretically the sme. Here the stresses in the longitudinal and transverse flanes of symetry are lou ard rise to their paxima levels on the intermediate gage 1ine. The distribution of stresses aloag the istermediate gage line is shown in Fig. 37 , wich is $45^{\circ}$ from 
the longitudinal place of symetry. Hert the edreecent is rery y00:. I-

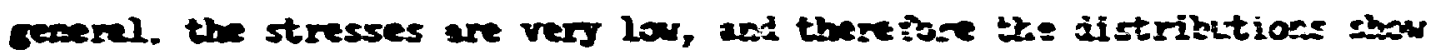
very pror quatitutive apreesent between theos' ani spericent-ul result:.

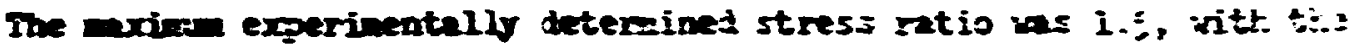
maina stress located oc the outer surface of the gorzle at tho jurctio:

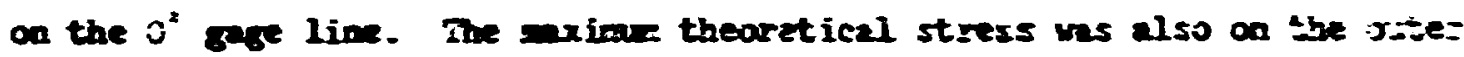

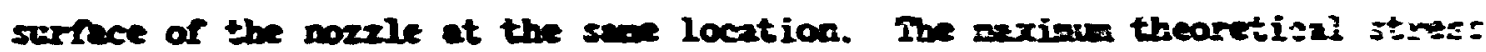
ratio us 1.0 .

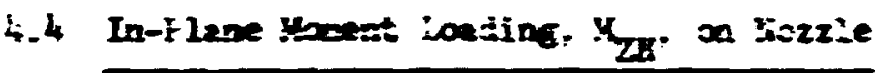

The neasured and predicted stress iistritutiocs for an in-plave =epent landing of i00 in.-10 applies to the sozzle ere shom in Figs. -:

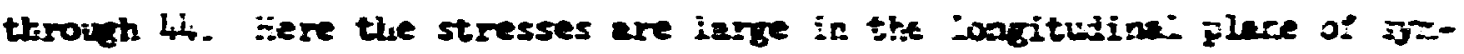

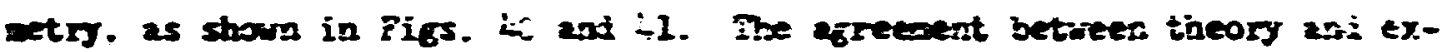

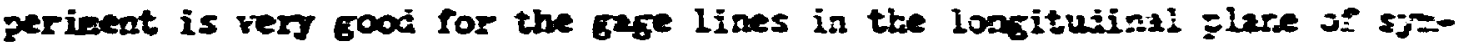
setry.

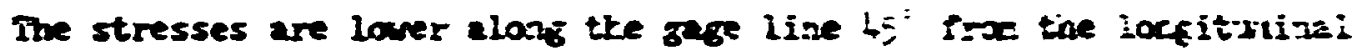
plane of sy=erry; in the trastresse flare of sy=etry. the stresses $a r=$ very lor (Figs. 43 and idi). For this loaji=8. the transverse finde $\vdots=$ somentat sinilar to the neurral axis of a ceas.

The axilan experinetally jeternizei stress ratio vas $6 . i$, wi-i. the saximan stress occurring on the outer surface of the nozxle at the function aloos the $i^{*}$ ang line. The saxisue theoretial stress 1 so oscurred on the outer aurface of the nozzle at the function alosef the if gage line. The stress retio was 7.2.

\subsection{In-Flane Poree, $F_{X,}$, on Hozzle}

The in-plane force applied to the nozzle had a vaiue of $\$ 0$ ib. The comparisons of theory and experiment for the eight gage liaes are shom in Pigs. is through 4y. The results here are very similar to the previous care of the in-plane bending moment on the sozzle, and the overi:l sorzewert is very gen. 
The maximum experimentally determined stress occurred on the inner surface of the nozzle at the junction along the $0^{\circ}$ gafe line; the ratio was 7.2. The maximum theoretical stress occurred on the outer surface of the nozzle at the junction along the $0^{\circ}$ gage line; the maximum theoretical stress ratio was 8.1 .

\subsection{Axial Force, $F_{\mathrm{YN}}$, on Nozzle}

The comparisons of theory and experiment for an axial force of 400 lo appliad to the nozzle are presented in Figs. 50 through 54. The agreement between theory and experiment is very good, except for the inside surface of the cylinder on the $315^{\circ}$ gage line, which is $45^{\circ}$ from the longitudiral plare of symetry. The agreement is very good, particulazly as the larger stress levels are approached on the transverse plane of symmetry (Figs. 53 and 54).

The experimentally determined maximum stress occurred on the inner surface or the nozzle on the $270^{\circ}$ plane at the junction; the ratio was 21.6. The theoret: ally determuned maximum stress occurred on the ouner surface of the nozzle on the $270^{\circ}$ gage line at the junction; the ratio was 13.9.

\subsection{Out-of-Plane Force, $\boldsymbol{F}_{\mathrm{ZN}}$, on Nozzle}

The comparisons of thescy and experimental data for an out-of-plane force of $60 \mathrm{lb}$ applied to the nozzie are presented in Figs. 55 through 5y. These results are very similar to the saze of out-of-Flane mament on the nozzle, and the orerall agreanent between theory and experiment is again very good, except on the inside surfare of the cylinder along the $315^{\circ}$ gage line (Fig. 57). Since the stresses are very small on the 0 and 100 gage lines, the agreement does not look as good as aiong other gage Lines.

The experimentally determinei maximum stress (ratio of 8.6 ) occurred on the inner surface of the nozzle along the $270^{\circ}$ gage line at the junction. The theoretically determined maximum stress (ratio of 8.5 ) occurred or. the outer s'arface at the same location. 


\subsection{Torsicnal Mowent Loeding, 'Xc' on Cylinder}

The comparisons of theory and experiment for a torsional moment of 30,000 in.-1b applied to the cylinder are presented in Figs. 60 through 64 . The experimental stresses are low in the longitudinal and transverse planes 0 . symetry and rise to their maxinum levels on the intermediate gage lin:e. The agreement between theory and experiment is satisfactory on the is.termediate iine. However, the maximum theoretical stress is 10cated on the $0^{\circ}$ plane on the nozzle.

The experimentally determined maximum stress occurred on the inner surface of the cylinder along the $315^{\circ}$ gage line at the junction, and the maximun stress ratio was 5.0. The theoretically determined maximum stress occurred on the outer surface of the nozzle along the $0^{*}$ gage line at the junction, ard she maximum stress ratio was 5.1 .

\subsection{Out-of-Plane Moment Loading, MY' on Cylinder}

The out-of-plane moment loading applied to the cylinder had a value of 80,000 in.-1b. The comparisons of theory and experiment are fresented in Figs. 65 through 69. The 0 and $180^{\circ}$ gage lines on the longitudinal plane of symetry are analogous to the neutral axis of a beam in bending, and the st,resses are tinus low. However, the stresses are not very large anywhere in the model. A peculiarity of the finite-element analysis calculates a large stress at the junction on the 0 and $180^{\circ}$ plares of symmetry which is obviously not correct. The maximum stress ratios for this case were the lowest of all 13 loading cases. As a result of the relativejy low stress levels, the stress distributions are not ton well defined on the 0,180 , and $315^{\circ}$ gage lines, and the agreement between theory and experiment appears to be relatively poor. However, on the gage lines of maximum stress $\left(270\right.$ and $90^{\circ}$ ). the agreement between theory and experiruent is fair.

Both the experimentally determined and the theoretical maximum stresses cccurred on the outside surface of the cylinder on the $90^{\circ}$ gage line. The experimental maximum stress ratio was 1.3 , and the theoretical was 1.0 . 


\subsection{In-Flane Monent Loading, $\mathrm{H}_{2 C^{\prime}}$ on Cylinder}

The comparisons of theory and experiment for the in-plane monent loading of 30,000 in.-1b applied to the crlinder are presented in Figs. 70 through 74. The stress levels are a maximum in the transverse plane of symetry, as shown in Figs. 73 and 74 , and agreement betreen experinental and analytical results is reasonably good. Where the stress levels are Iower along other gage lines, the apparent agreement between theory and experiment is poorer.

The experimentally determined and the theoretical maximum stresses cccurred on the inside surface of the cylinder at the junction. The experimental maximum was on the $90^{\circ}$ gage line, while the theoretical maximum occurred both on the 90 and $270^{\circ}$ gage lines. The maximum experimental stress ratio was 4.0 , and the maximum theoretical ratio was 3.1 .

\subsection{Axial Forme, $F_{X C^{\prime}}$ on Cylinder}

The axial force applied to the cylincer had a value of 10,000 $\mathrm{lb}$. The comparisons of theory and experiment for the five bage lines are presented in Figs. 75 through 79. Considering the relatively low stresses, the agreement between theory and experiment is reasonably good throughout. The agreement between theory and experiment is good for the 270 and $90^{\circ}$ gage lines on the nozzle, as shown in Figs. 78 and 79.

The experimentally determined and the theoretically predicted maximum atresses occurred on the inner surface of the cylinder at the junction. The experimental maximum was on the $90^{\circ}$ gage :ine, while the theoretical value was on both the 270 and $90^{\circ}$ gage lines. The experimental maximum stress ratio was 3.7 ; the theoretical stress ratio was 3.0 .

\subsection{In-Plane Force, $F_{Y C}$, on Gylinder}

The comparisons of theory and experiment for the in-plase force of 3000 Ib applied to the cylinder are shown in Figs. 80 chrough 84 . The agreement betwees theory and experiment is very good for this loading case. 
Both the experimentally coternined and the theoretical maxim stresses occurred on the inside surface of the cylinder at the junction. The experimental waxinu wes on the $90^{\circ}$ eage line, while the theoretica: maxian vas on both the 270 and $90^{\circ}$ bage lines. The maxima experimental stress ratio ws 4.1, and the maximan theoretical ratio wes 3.2 .

\subsection{Out-of-Plane Force, $F_{Z C}$, on Gylinder}

The comparisons of theory and experinent for the out-of-plane force of $3000 \mathrm{lb}$ applied to the cylinder are shown in Pigs. 85 through 89 . The 0 and $180^{\circ}$ gage lines, in the longitudinal plane of symetry, are analogous to the neutral axis of a bean, so that the stresses are iow along these gage lines. However, the stresses build up for the other gage lines, and the agreement between theory and experinent is very good. A peculiarity of the finite-elerent analysis calculates a large stress at the junction on the $\mathrm{O}$ and $180^{\circ}$ planes of symetry on the nozic which is obviously not correct. These points vere neglected.

Both the experimentelly determined maximum and the theoretical maximm stresses occurred on the inner surface of the cylinder at the junction along the $315^{\circ}$ gage line. The maximu experimental stress ratio was 1.3 , while the maximum theoretical ratio was 1.2 .

\section{5. concuUsions}

Table 2 represents an attempt to concisely sumarize the principal findings of this study in terms of maximum principal stress ratios, locetions of maximum principal stresses, and the relative overall agreement between theory and experiment for sach loading case. The maximum stress ratios are based on the stresses, either measured or predicted, along the five lines of strain gages only and were determined by dividing the maximu absolute principal stress value by a nominal membrane st.ress value. The maximum experimental principal stresses vere determined by extrapolating the experimentally determined stress distributions to peak stresses at the juxction in all but one case. 


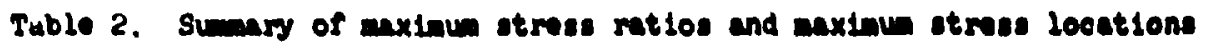

\begin{tabular}{|c|c|c|c|c|c|}
\hline \multirow{2}{*}{ Loading case } & \multicolumn{2}{|c|}{$\begin{array}{l}\text { Exporimentelly deterwinod } \\
\text { anximus otrese }\end{array}$} & \multicolumn{2}{|c|}{$\begin{array}{c}\text { Theoretioel maximin } \\
\text { itgese }\end{array}$} & \multirow{2}{*}{$\begin{array}{l}\text { overeli egree- } \\
\text { nont botween } \\
\text { theory and } \\
\text { experingats }\end{array}$} \\
\hline & Strose rat $10^{b}$ & Location" & Stroa ret $10^{b}$ & $1000 t 10 n^{\circ}$ & \\
\hline Internal preasure & 3.5 & Inside cylinder, $180^{\circ}$ & 3.2 & Outesde nosste, $0^{\circ}$ & oood, poor \\
\hline Hox, out-of-plane & 8.5 & Inside nosxle, $270^{\circ}$ & 7.6 & Outelde noss2e, $270^{\circ}$ & Exoel lent \\
\hline $\begin{array}{l}\text { Mn, torstomal wo- } \\
\text { Ant on noande }\end{array}$ & 1.5 & Outside noszle, $0^{\circ}$ & 1.0 & Outsesde nossle, $0^{\circ}$ & Poor \\
\hline $\begin{array}{l}\text { Mas' In-plane nowont } \\
\text { on noxie }\end{array}$ & 6.1 & Outside nossle, $0^{\circ}$ & 7.2 & Outside nosele, $0^{\circ}$ & Exeoldent \\
\hline $\begin{array}{l}\text { Pos. In-plan tores } \\
\text { on noszle }\end{array}$ & 7.2 & Inelde nossle, $0^{\circ}$ & 8.2 & Outelde noss le, $0^{\circ}$ & Exoedient \\
\hline Trme exted roree on & 22.6 & Inside noss $10,270^{\circ}$ & 23.9 & Outelde noss $20,270^{\circ}$ & $000 d$ \\
\hline $\begin{array}{l}\text { Fag, out-of-plam } \\
\text { fobree on noszle }\end{array}$ & 8.6 & Inxide noss2e, $270^{\circ}$ & 8.5 & Outesde noss $20,270^{\circ}$ & cood \\
\hline $\begin{array}{l}\text { Mxc, torstonal monent } \\
\text { on cylinder }\end{array}$ & 5.0 & Inside oyl1 ndor, $325^{\circ}$ & 5.2 & Outerdes nosele, $0^{\circ}$ & $000 d$ \\
\hline $\begin{array}{l}\text { Myc, out-or-plane } \\
\text { woint on cylindor }\end{array}$ & 2.3 & artelde cyl1nder, $90^{\circ}$ & 2.0 & Outeide oylinder, ${ }^{d} 90^{\circ}$ & Fadr \\
\hline $\begin{array}{l}\text { Meg, In-plan sement } \\
\text { of cyllader }\end{array}$ & 4.0 & Inalde cylinder, $90^{\circ}$ & 3.3 & Inelde eylinder, $90^{\circ}$ & Fals \\
\hline $\begin{array}{l}\text { Pxcp extal fore on } \\
\text { gilinder }\end{array}$ & 3.7 & Inolde oyllnder, $90^{\circ}$ & 3.0 & Inalde oylinder, $90^{\circ}$ & cood, peor \\
\hline $\begin{array}{l}\text { Tyc, In-plon faree } \\
\text { of: cyllndur }\end{array}$ & $4 . \therefore$ & Inalde oylindor, $90^{\circ}$ & 3.2 & Inside oylinder, $40^{\circ}$ & Exeeldent \\
\hline $\begin{array}{l}\text { Fzc, oist-of-plane } \\
\text { force or: cyllinder }\end{array}$ & 2.3 & Inalde oylinder, $325^{\circ}$ & 2.2 & Inslde oylinder, $325^{\circ}$ & Palr \\
\hline
\end{tabular}


The relative orerall agreesent between the finite-elenent predictions and the experinental results is rated in the table as excellent, good, rair, or poor. These ratings are, of course, a natter of opinion, but an atte pt was ade to ente an unbiased evaluntios by basing thea on both the orerall qulitative agreement along the gage lines and on the quantitative agrevent in areas where the stresses vere relatively high. For the Internal pressure case and the case of an axiel loading on the wlinder, the relative rating is listed as good, poor; that is, the agreenent wes good in regions where the stress levels were relntively high but poor in regions where the vere relntively $10 \mathrm{~s}$.

Table 2 indicates that geperally the experinentally deternined andiman stress ratios and those besed on finite-elenent predictions are in good agreenent. Purthermore, the degree of agreesent between the stress ratios genernily correlates well with the relative ratings of the orerall agreenent between theory and experinent. Cenerally, the agreenent was best for cases involving loadings on the nozzle. However, the torsional wont on the nozzle was an exception; there the agreenent was poor quilitatively and quantitatively.

In every londing case except one, the maximu stress occurred at the junction of the nozzle and cylinder. In the one exception, which was the case of an out-of-plane wonent, MY, on the cylinder, the maxila occurred on the outside surfece of the cylinder at approximately $90^{\circ}$ around on the transverse plane (around at the side of the cylinder). The stresses on the inside surface of the cylinder vere, havever, almost as high as those on the outer surface.

In 7 of the 13 cases, the maxim values occurred in the transterse plane of symetry. The torsional moment on the cylinder and the out-orplare force on the cylinder produced maximu stresses at points intermediate to the two plones of symetry. The other four cases produced naximum stresses in the longitudinal plane of symetry.

Pinally, it should be pointed out that, as would be expected, the out-of-plane mosent and force loadings on the nozzle produced quite sindlar results, and the in-plane moment and force loadings on the nozzle produced simflar results. The stress dietributions were very sindlar for each peir, and the maximu stress ratios were very close. 
In conclusion, the comparison of these particular finite-elenent prefictions with the experinental results shours reasonably good agreenent. It is felt that this analysis would be satisfactory for nost engineering purposes.

Hoverer, there is roo for improvenent, particularly in the out-ofplane went and force loadings on the cylinder. The finite-elenent analysis for these cases calculated a large stress at the junction on the longitudinal plane of symetry wich obviously is not correct. The inclusion of the sixth degree of freedon, at least in the junction region, vioht inprove the predictions.

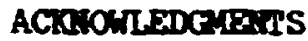

The planing and execution of the anslytical and experimental study reported here would not have been possible without the assistance and cooperation of may individuals, both within ORIL and outside. The authors are deeply indebted to these people for their contributions.

Special thanks are due J. P. Rudd for the instrumentation of the model, which was a very painstakirg task. The finite-element computer progran used in the analysis was developed at the University of California, Berkeley, by C. P. Johnson under the direction of Professor R. $W$. Clough. 


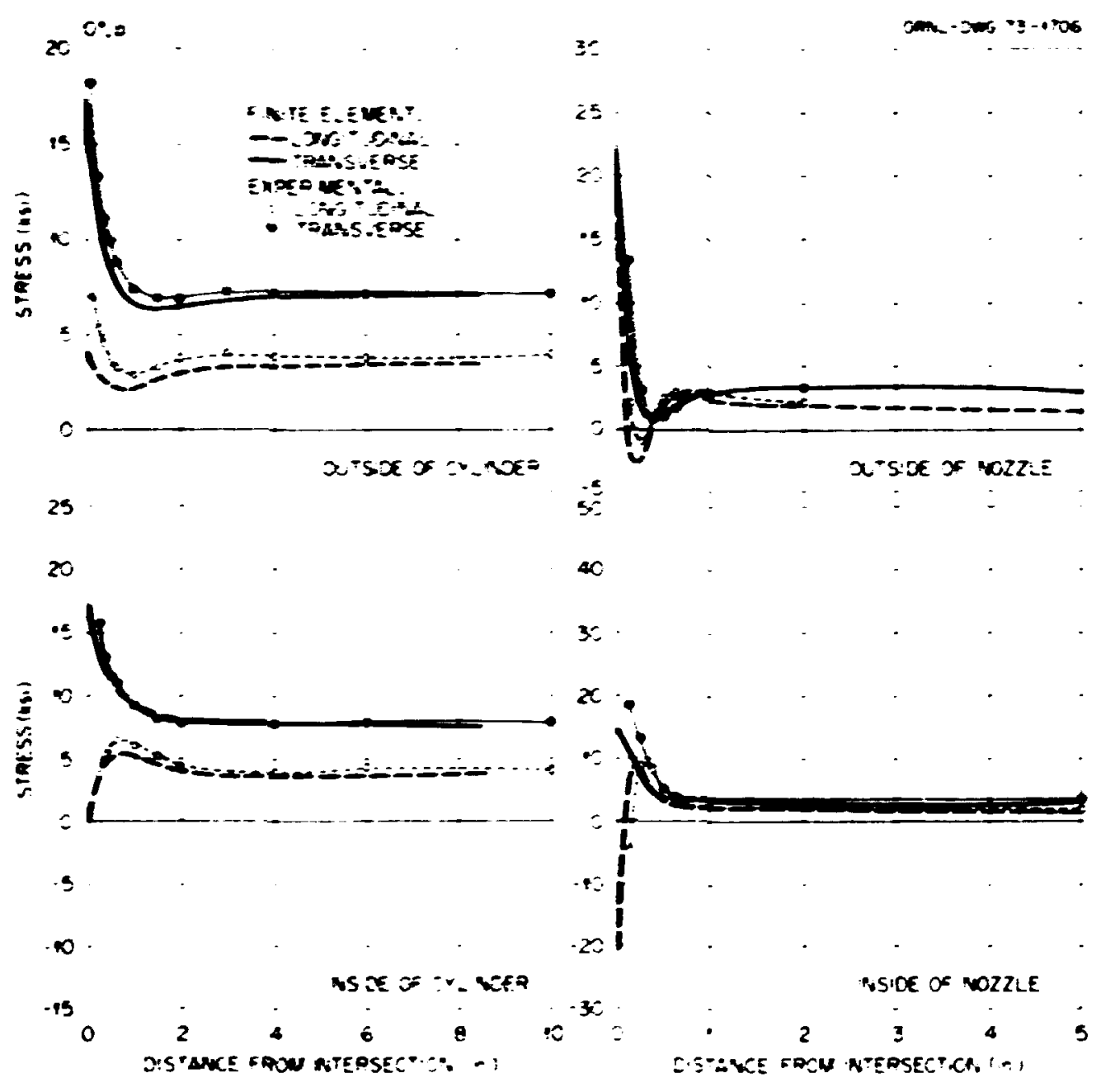

Pi8. 25. Measured and predicted stress distributions at $0^{\circ}$ for internal pressure of $300 \mathrm{psi}$. 

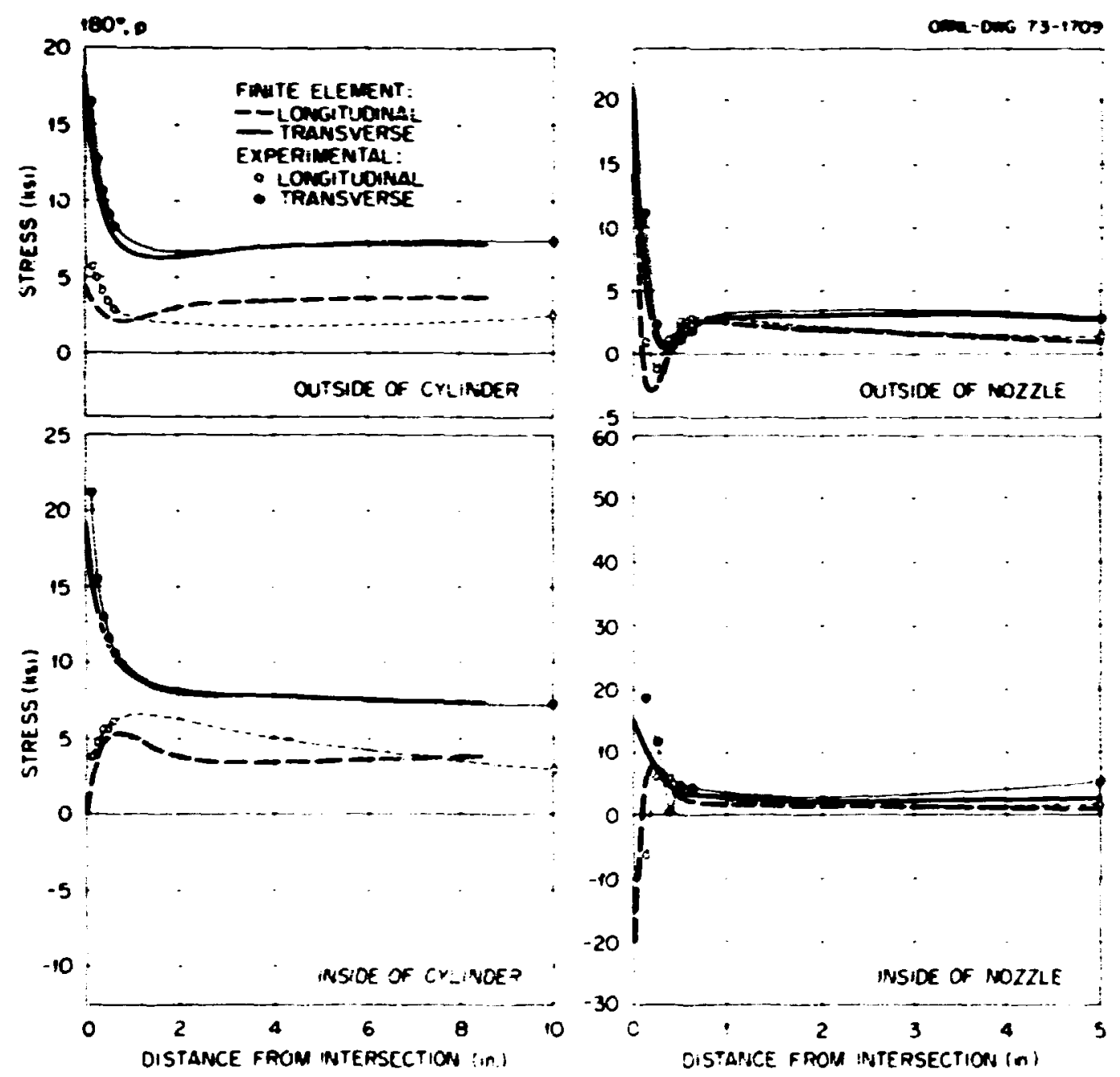

Fig. 26. Measured and predicted stress distributions at $190^{\circ}$ for internal pressure of $300 \mathrm{psi}$. 


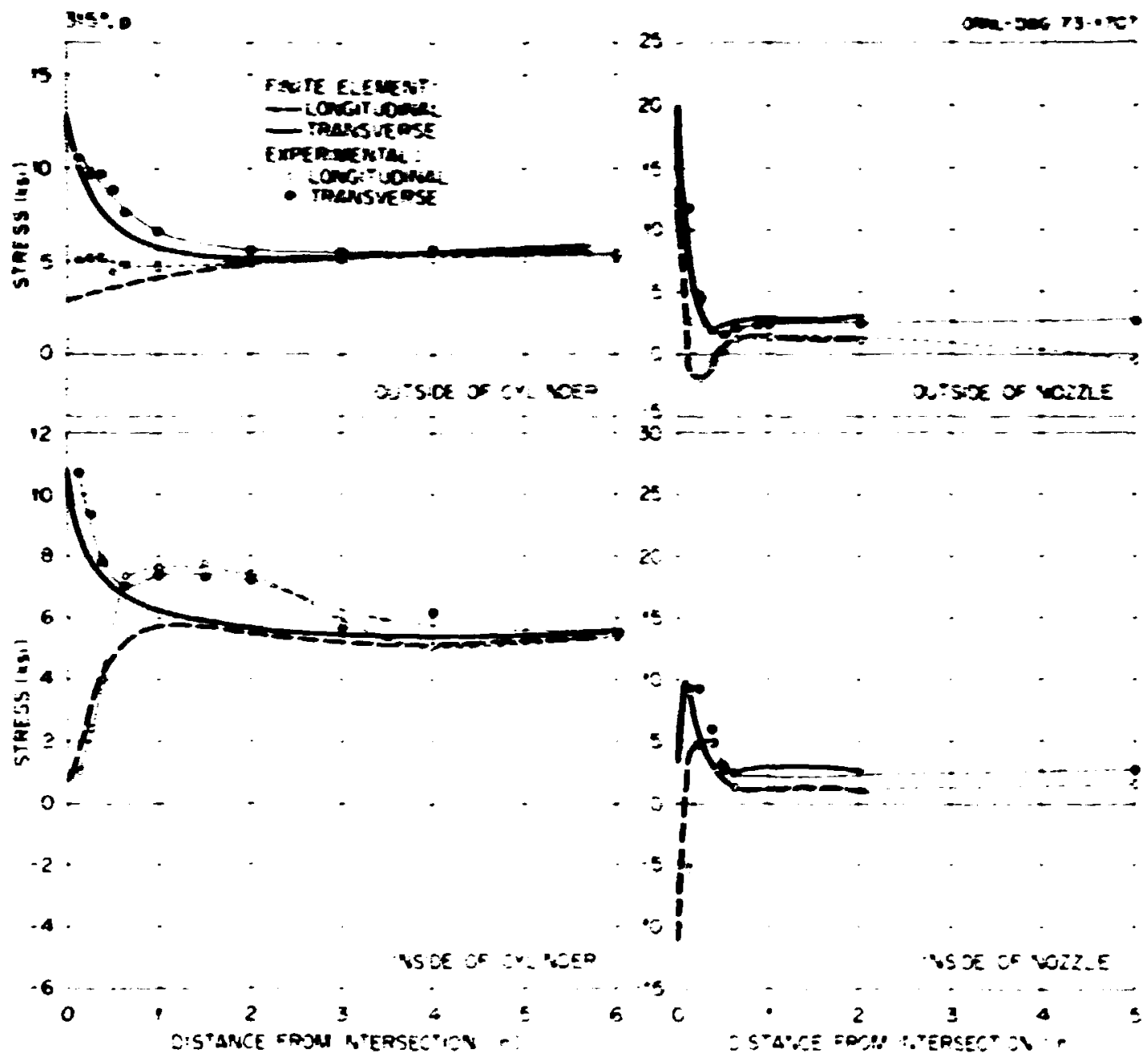

Pig. 27. Measured and predicted stress distributions at $315^{*}$ for internal pressure of 300 psi. 


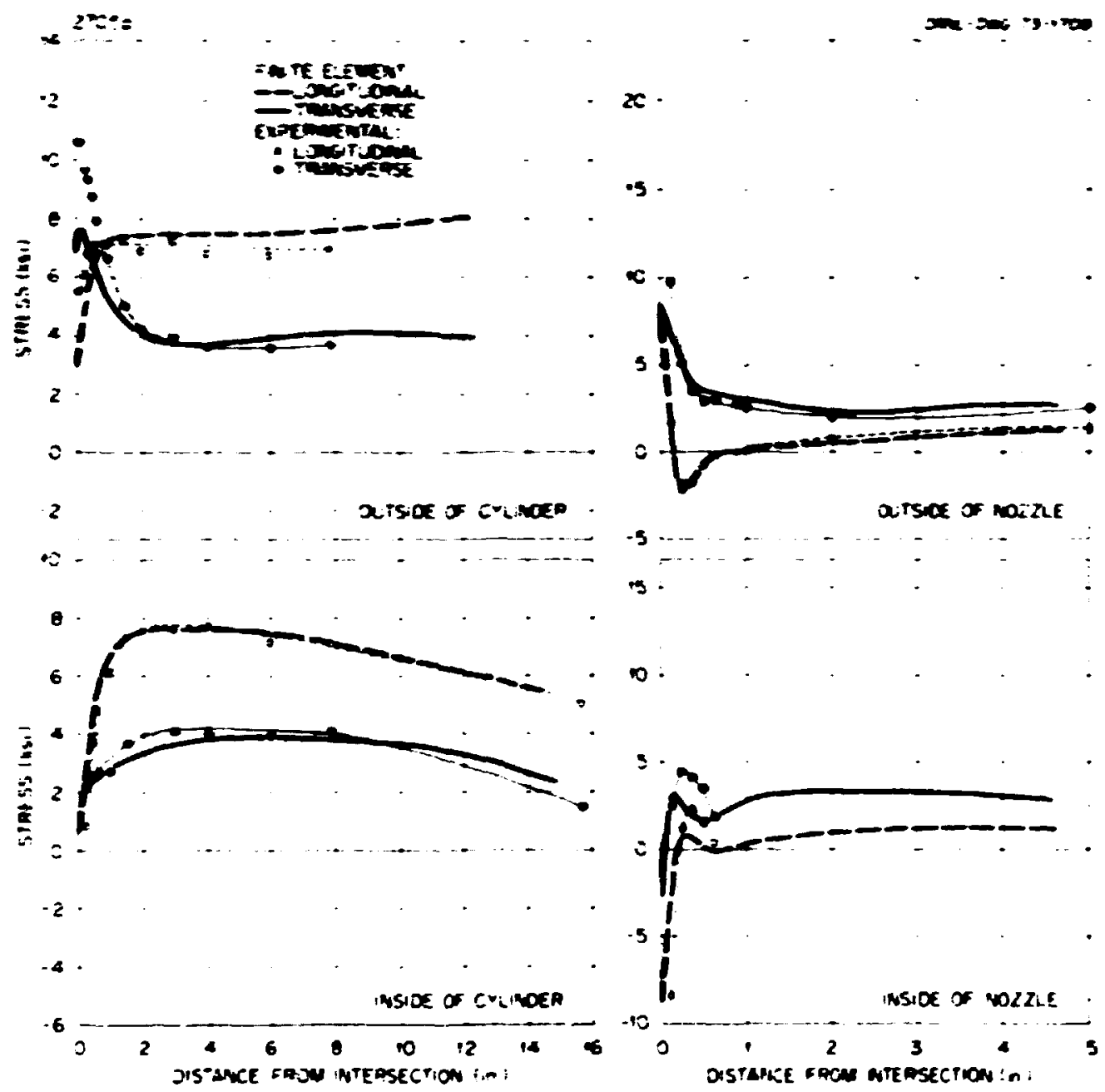

Pig. 28. Measured and predicted stress distributions at $270^{\circ}$ for internal pressure of 300 pet. 


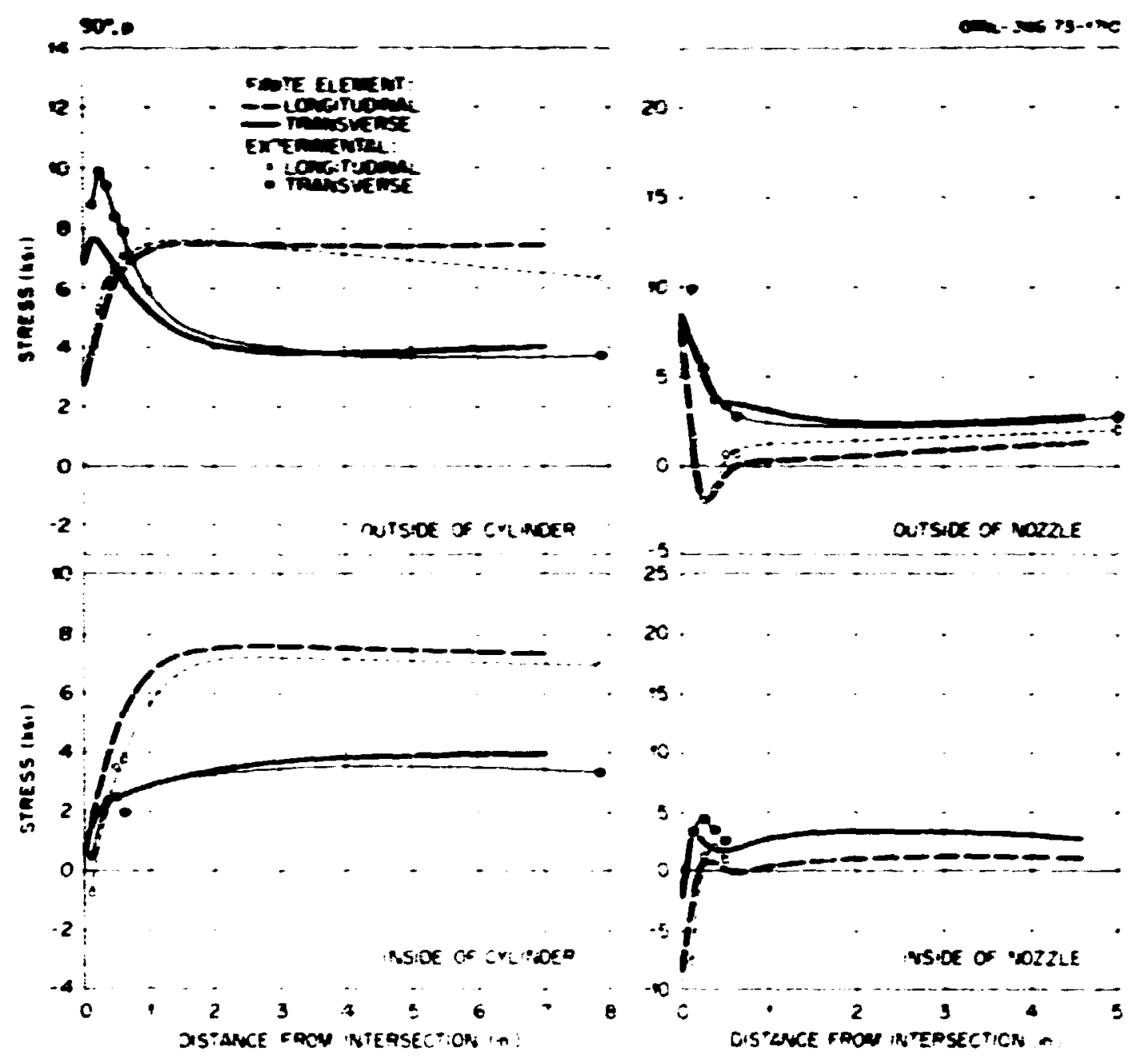

P18. 29. Measured and predicted stress distributions at $90^{\circ}$ for internal pressure of 300 pet. 
OnNG- OW Iy-1011
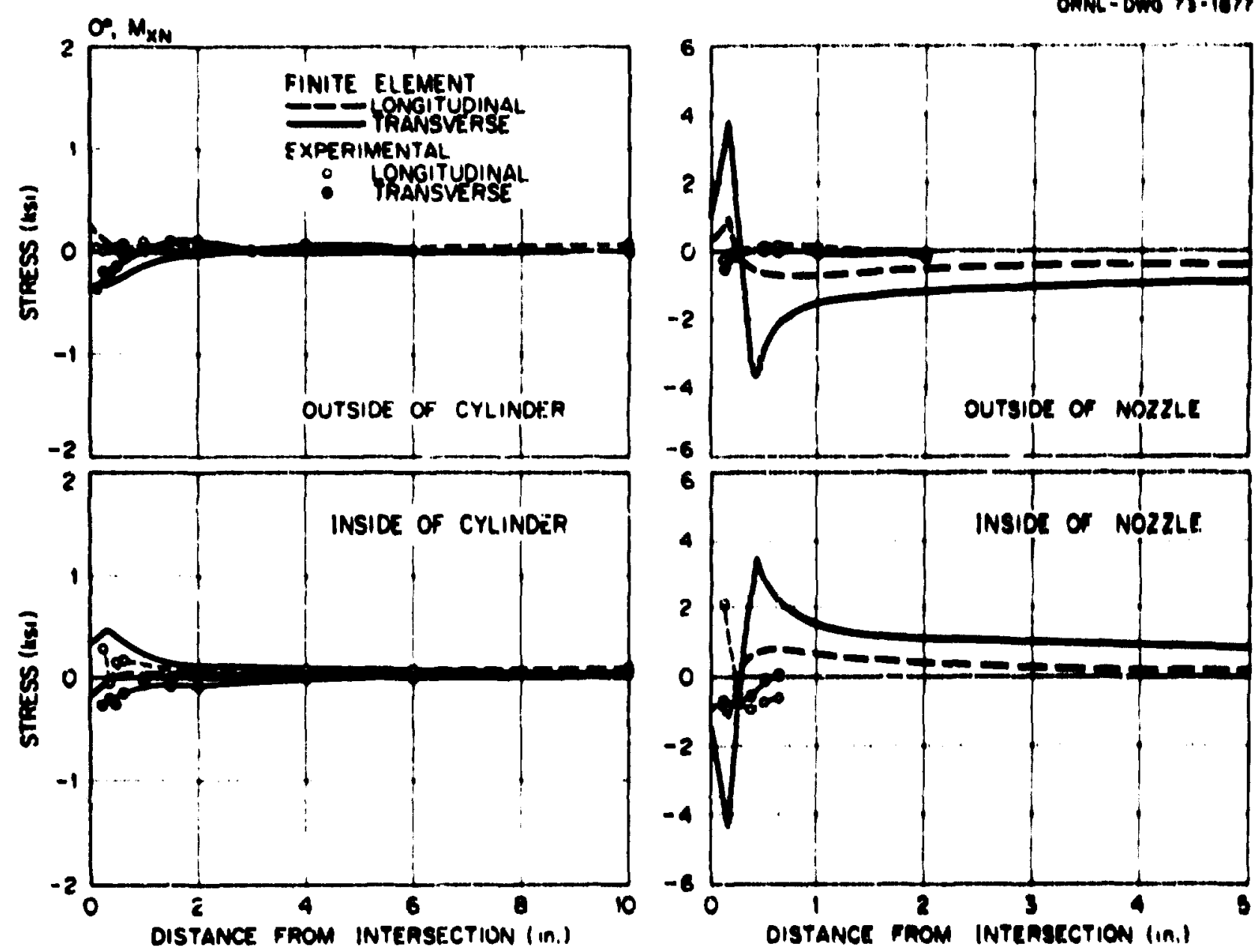

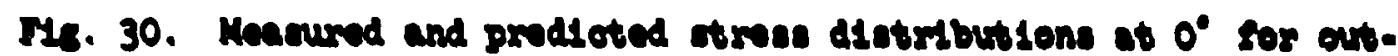
of-plane monont, Mos, on nosils. 

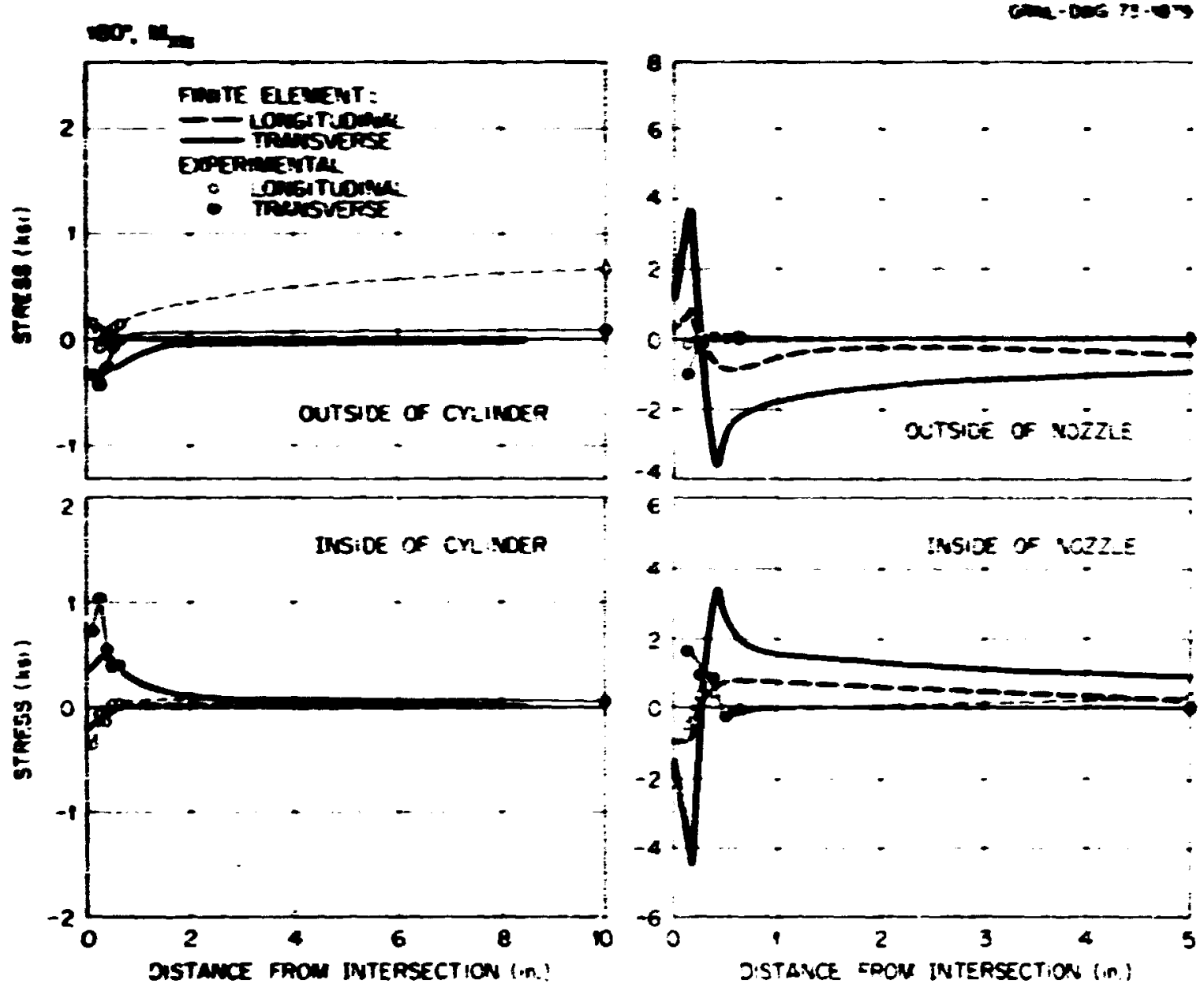

P18. 31. Hensured and predicted stress distributions at $180^{\circ}$ for

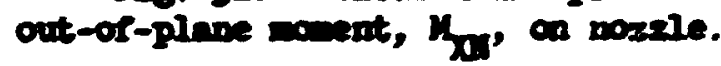



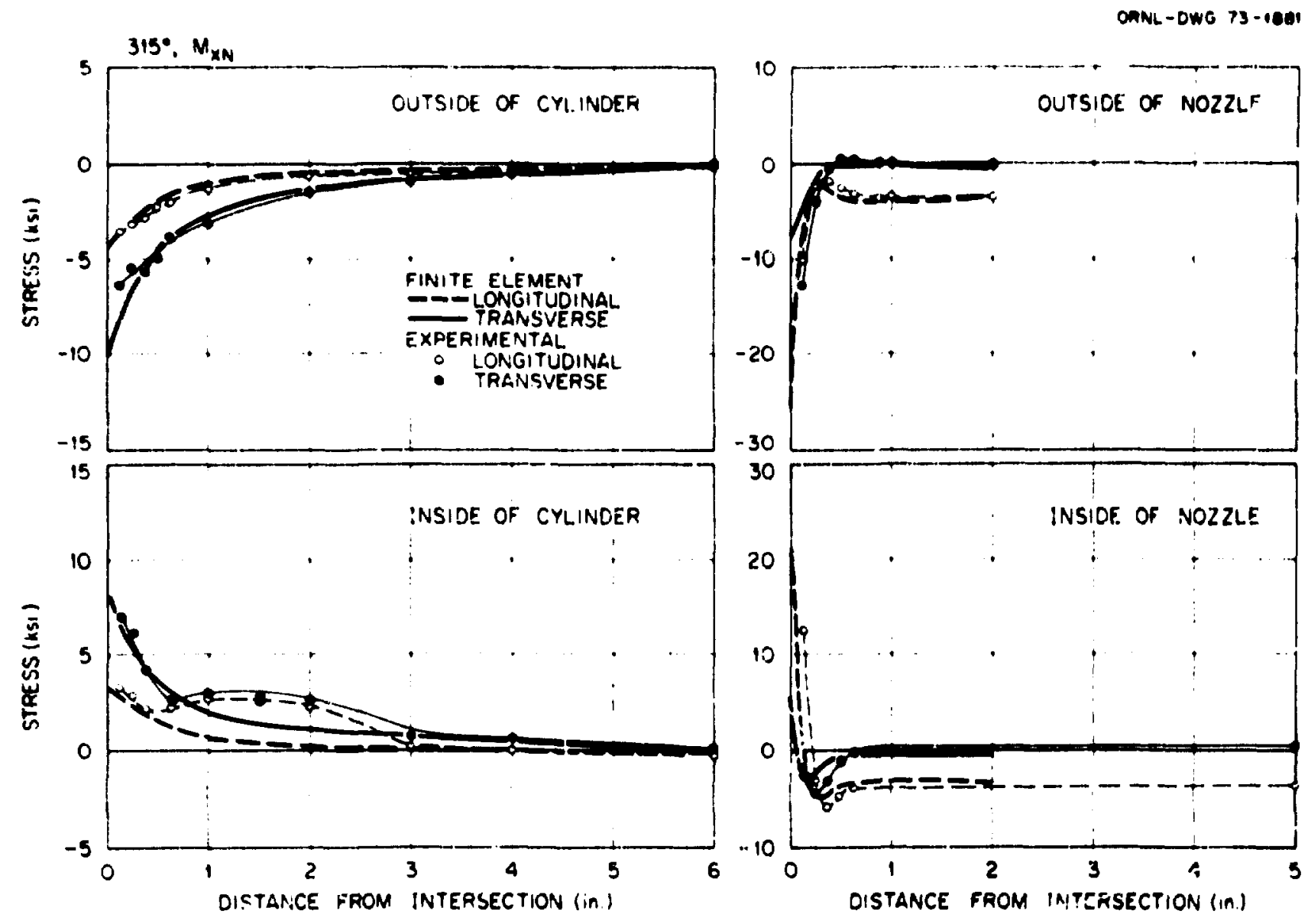

Fig. 32. Measured and predicted stress distributions at $315^{\mathrm{J}}$ for out-or-plune mament, Mav' on nozzle. 

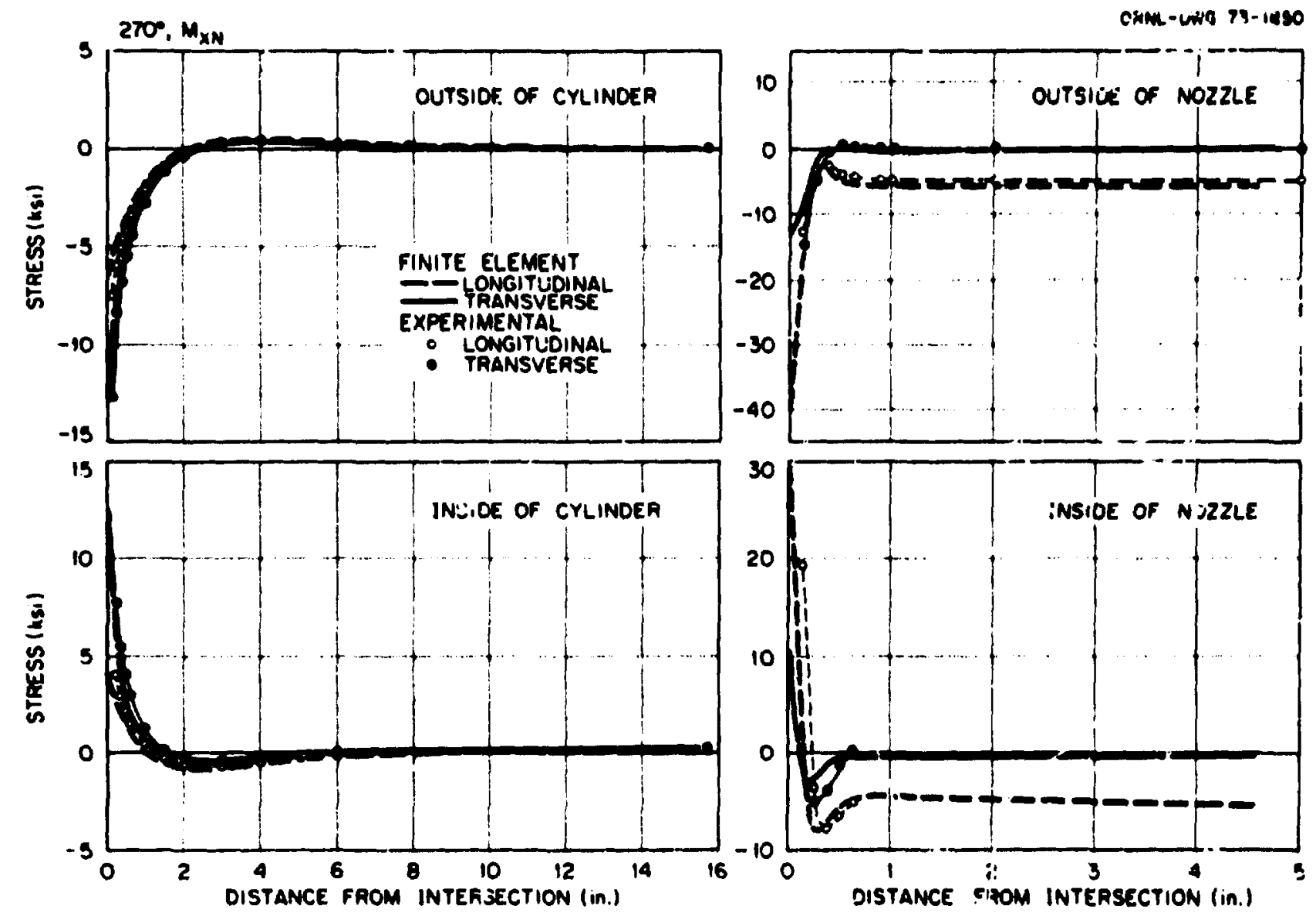

F16. 33. Mearured and prodicted stress dintributions at $270^{\circ}$ for out-or-plane moment, Mar, on nosele. 

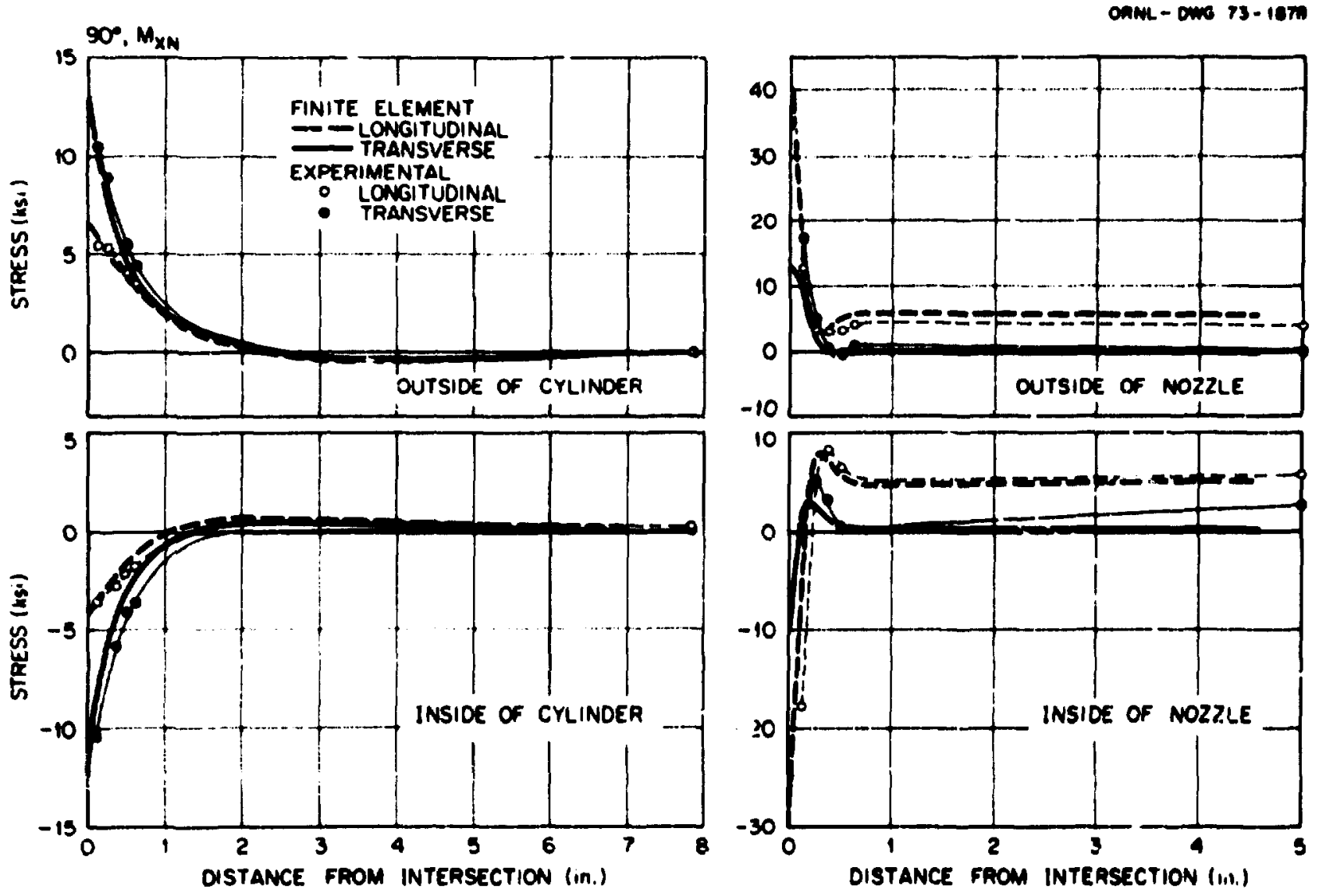

F18. 34. Moasured and prodicted atrose dintributions at $90^{\circ}$ for outof-plane moment, Max, on nosele. 

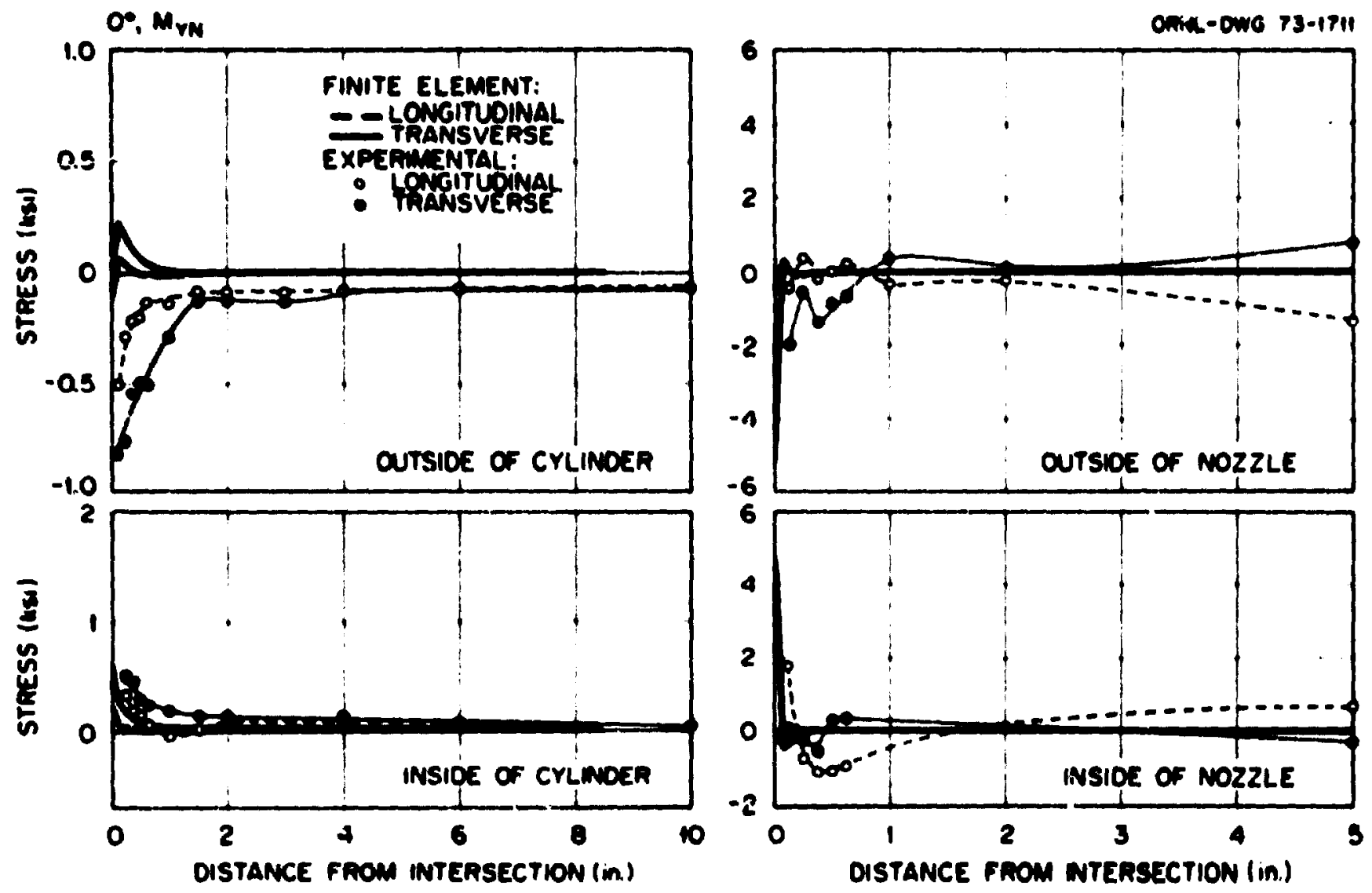

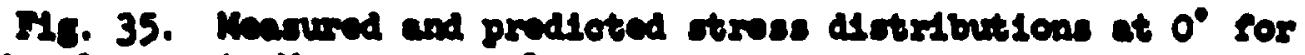
taresconal momont, Kly, on noasle. 

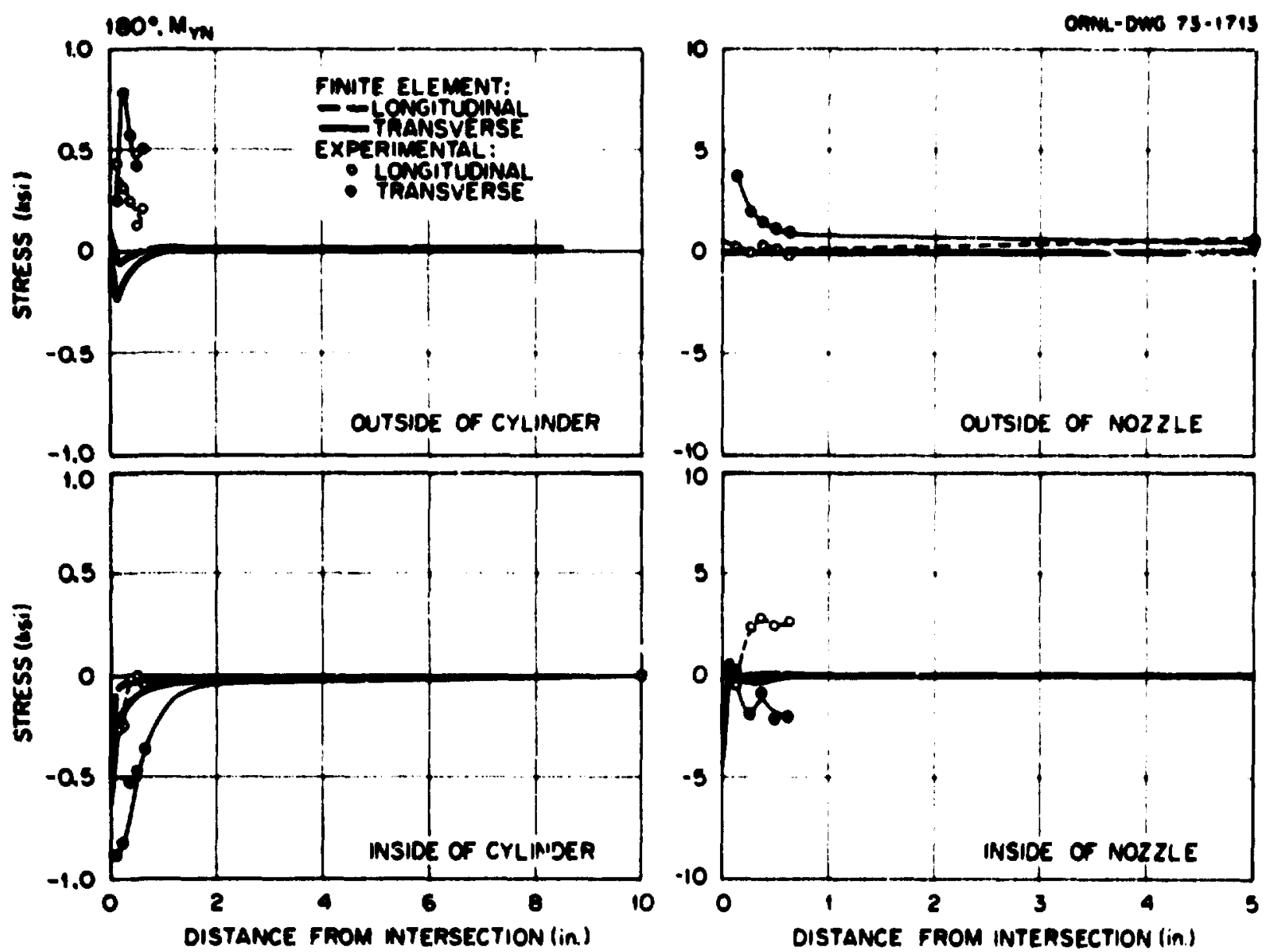

I6. 36. Moanured and prodtotod atrose dintributions at $280^{\circ}$ sor torelonel momont, Mri, on noxslo. 

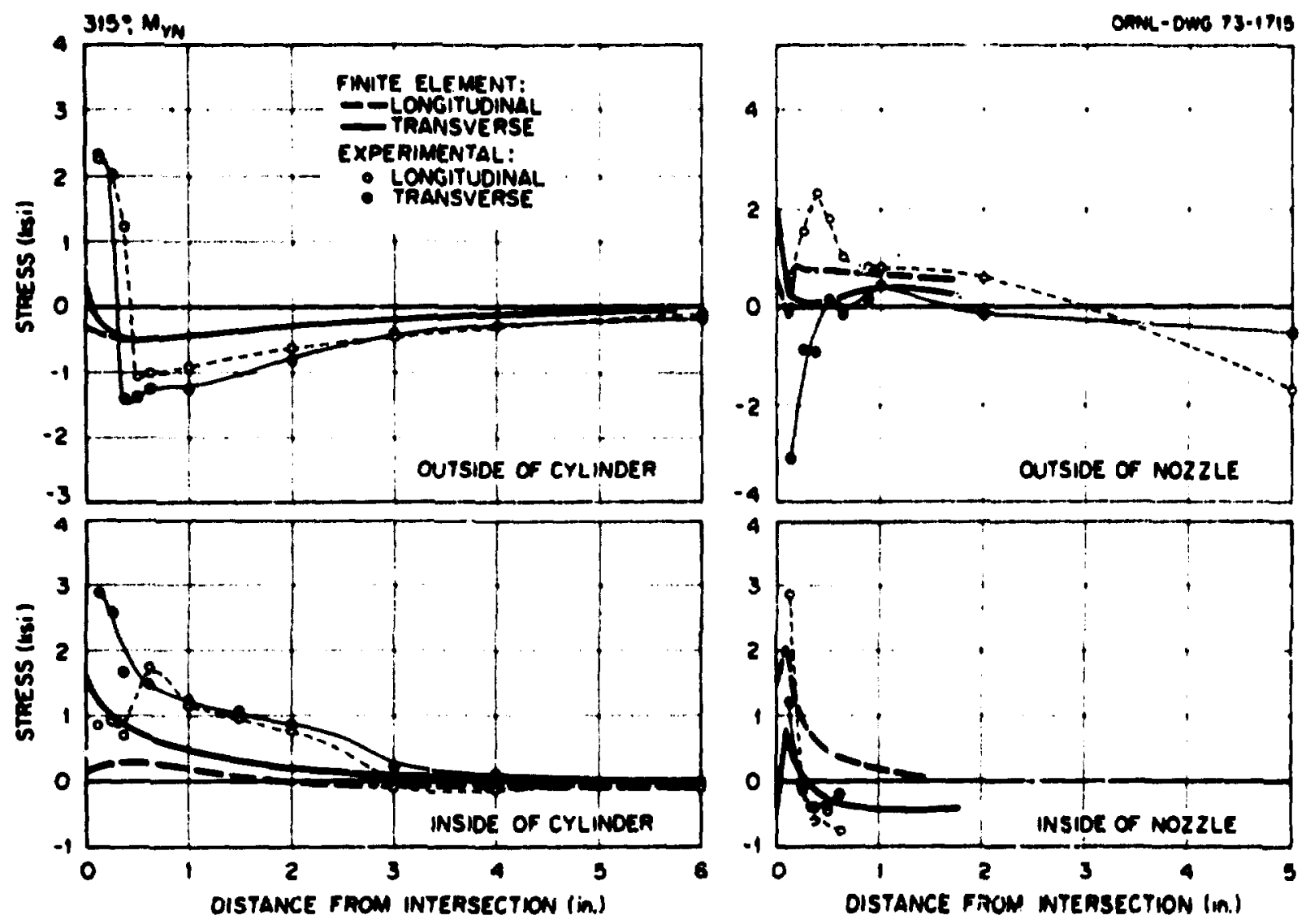

M6. 37. Moarured and prodioted streas diatributlon at $315^{\circ}$ for toretonal womot, Mus, on nossle. 

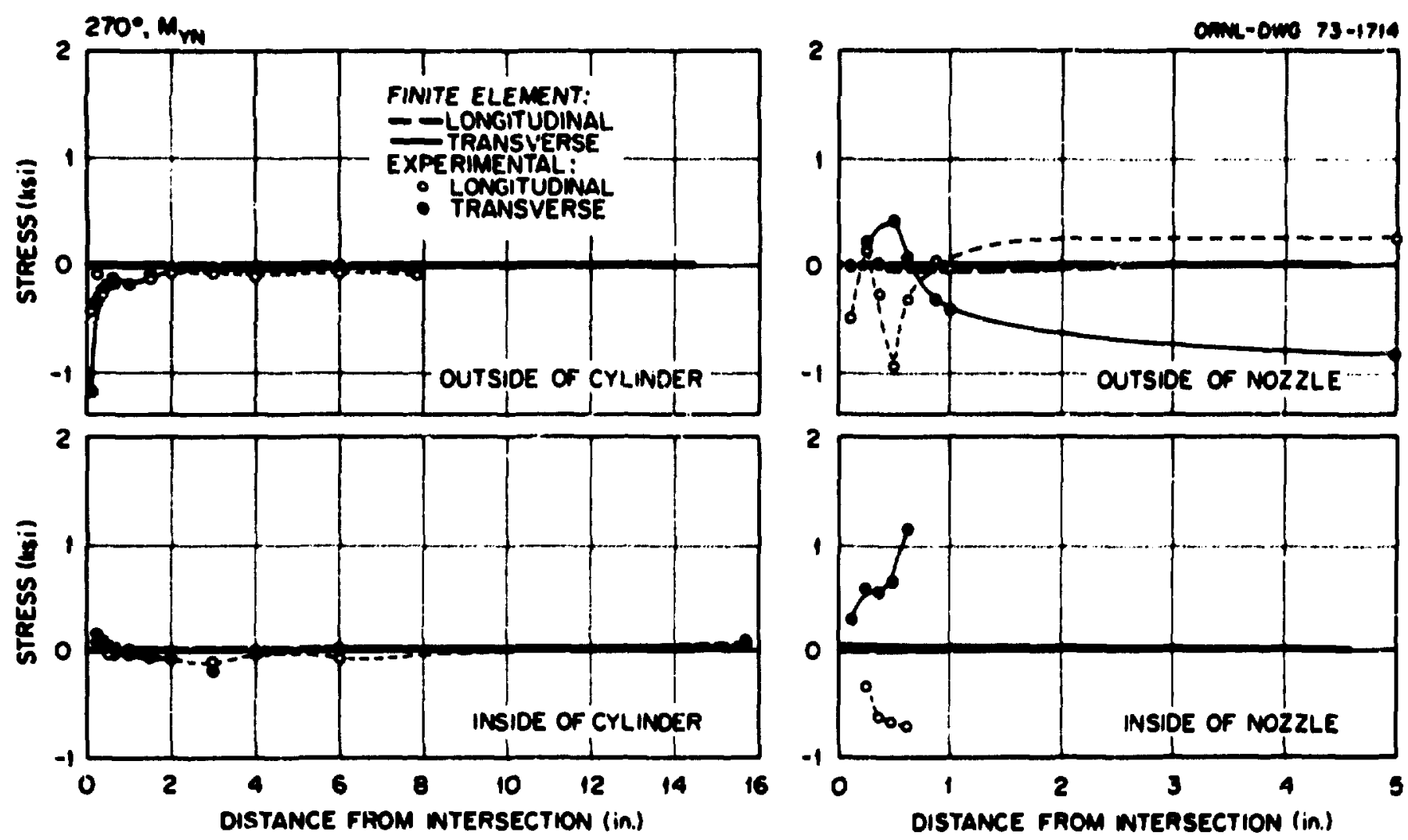

19. 35. Measured and prodloted otrese distributions at $270^{\circ}$ for

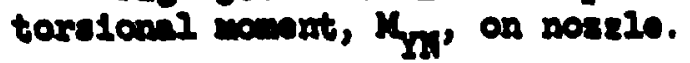



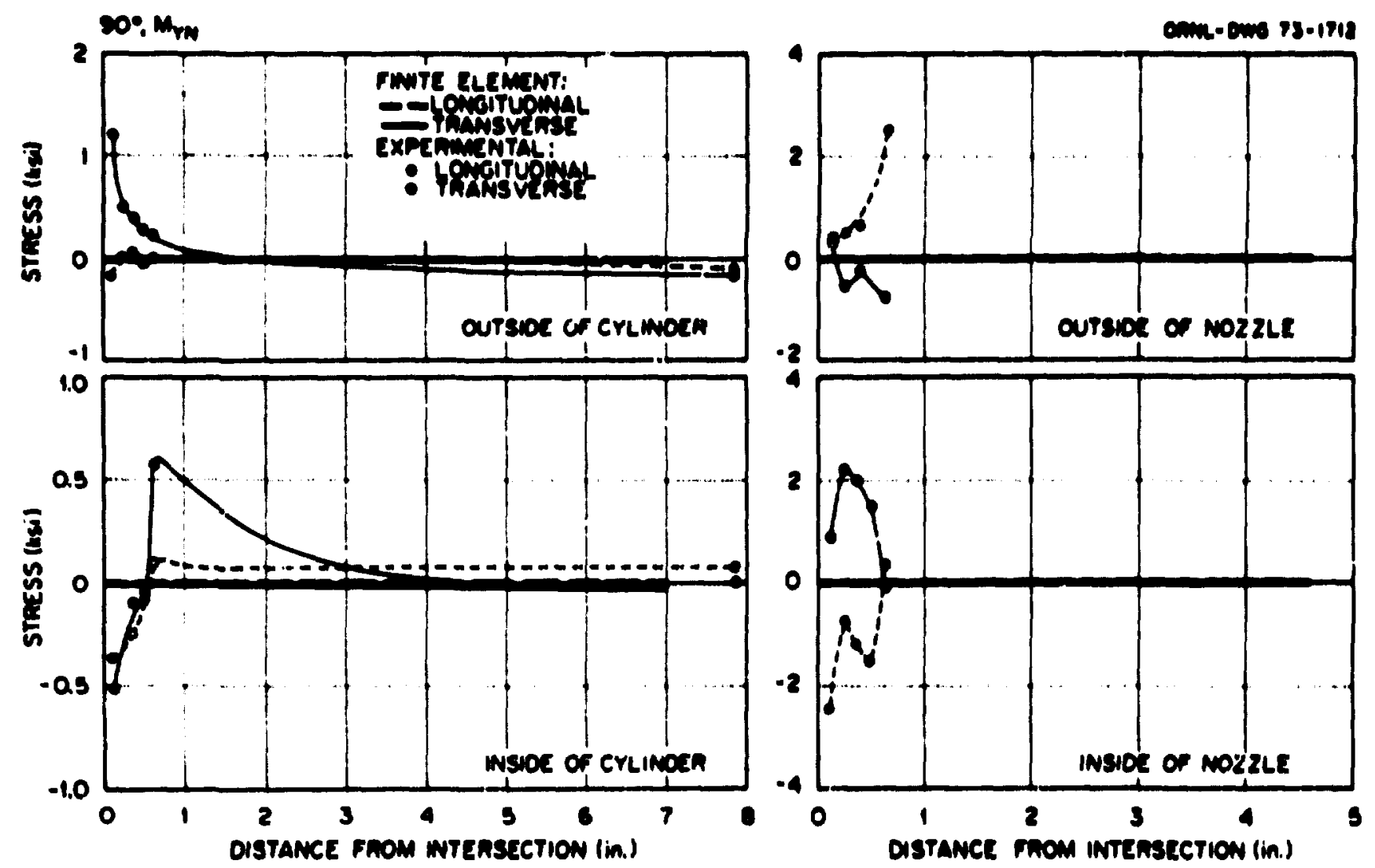

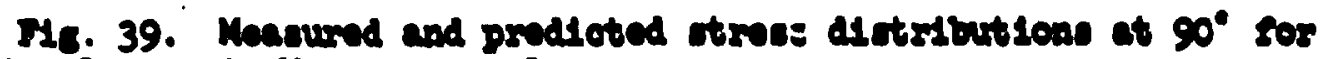

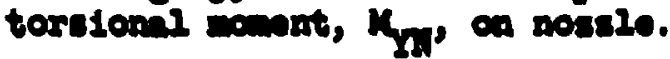



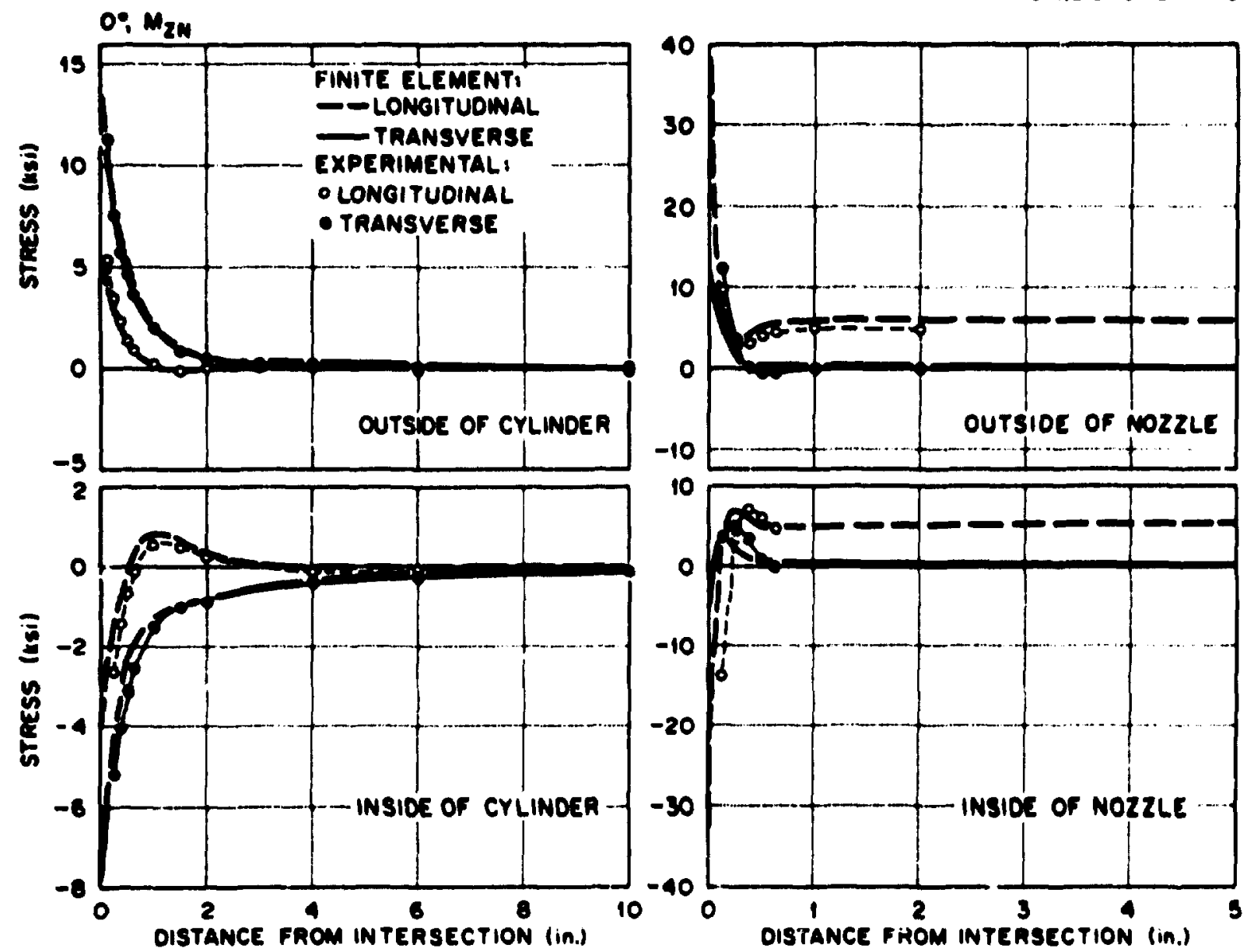

I16. 40. Hasured and prodletod strese distributions at $0^{\circ}$ for inplane momeat, $M_{\text {zil }}$, on nossio. 
ORHL OW IS-1710
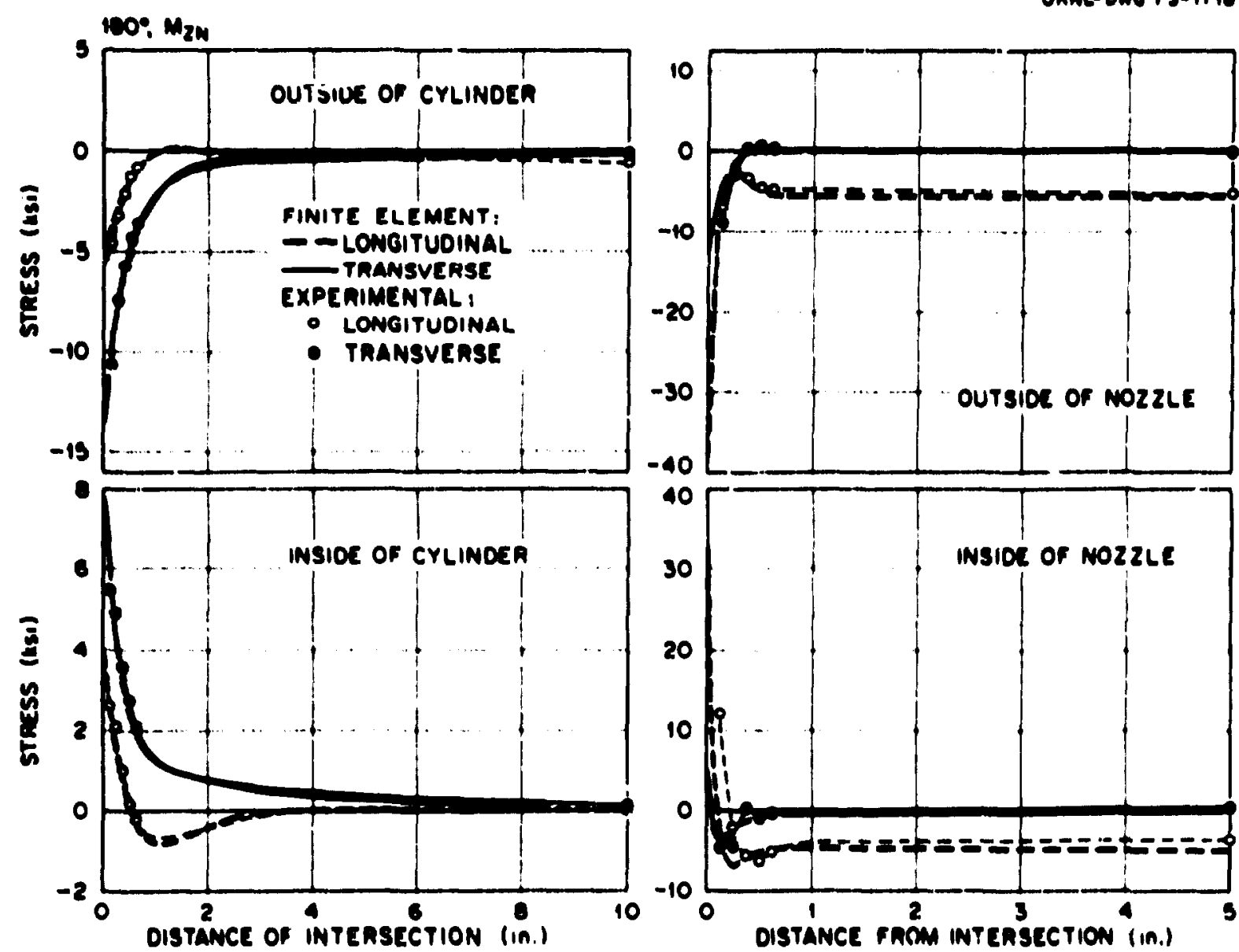

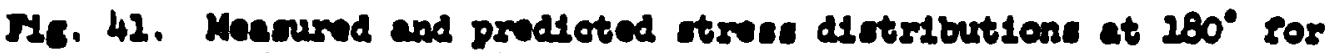
In-plane menont, $M_{2,}$, on nosiso. 

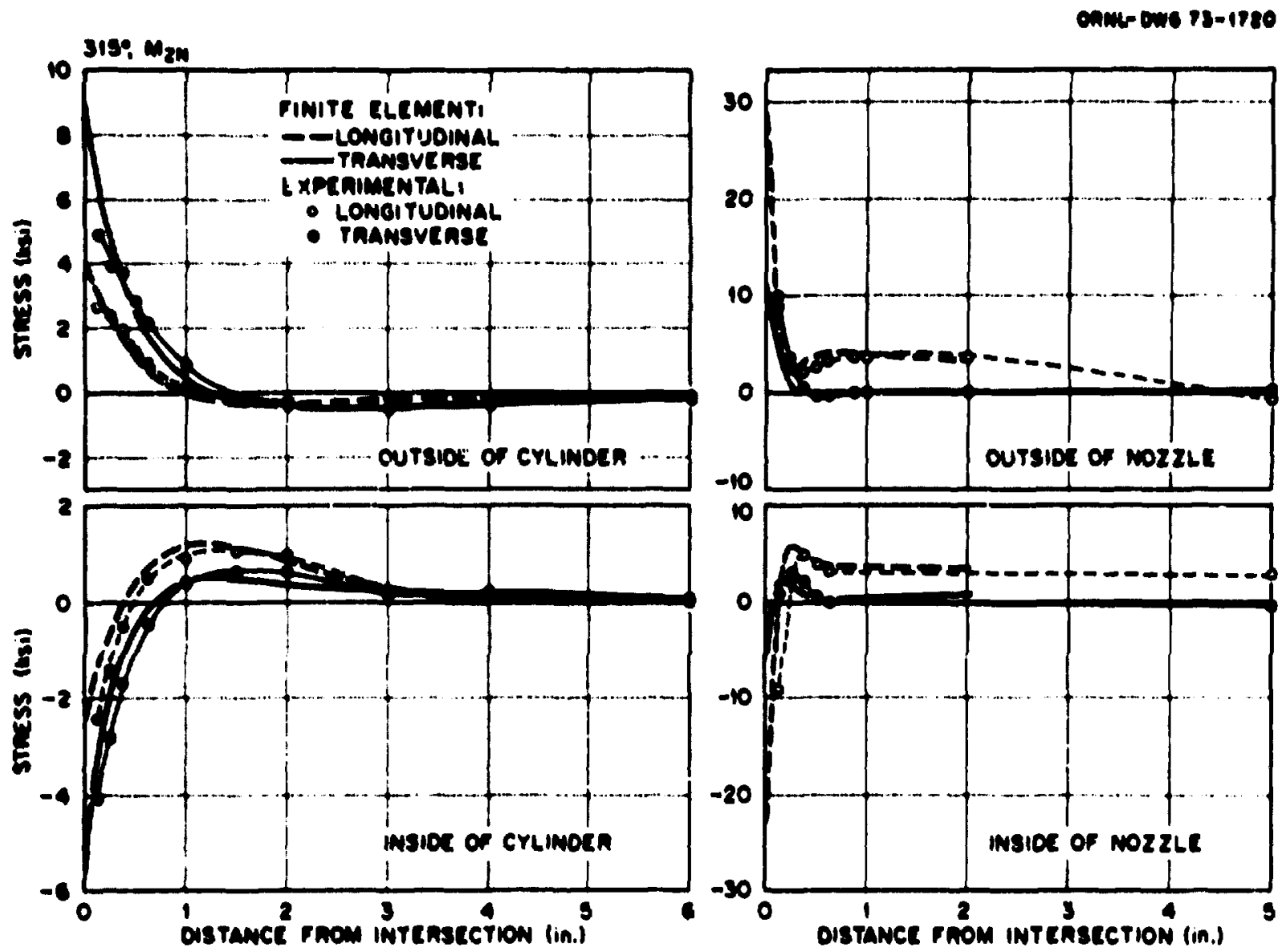

71. 42. Meecured and prodloted trose distributions at $315^{\circ}$ for

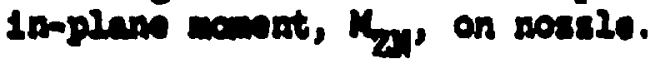



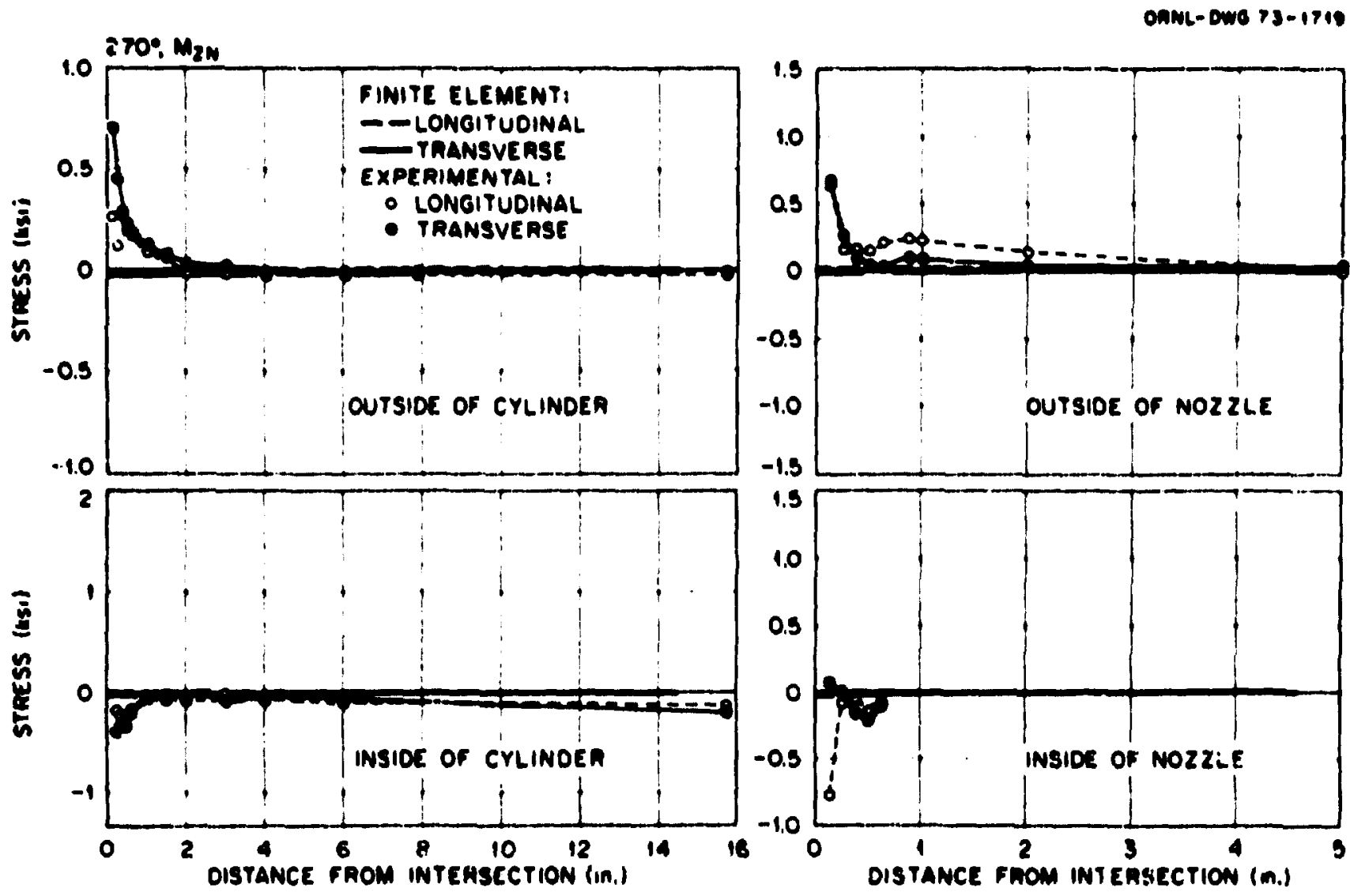

F18. 43. Meanured and prodfeted stross diatributions at $870^{\circ}$ sor In-plape momont, $K_{21}$, on nosislo. 

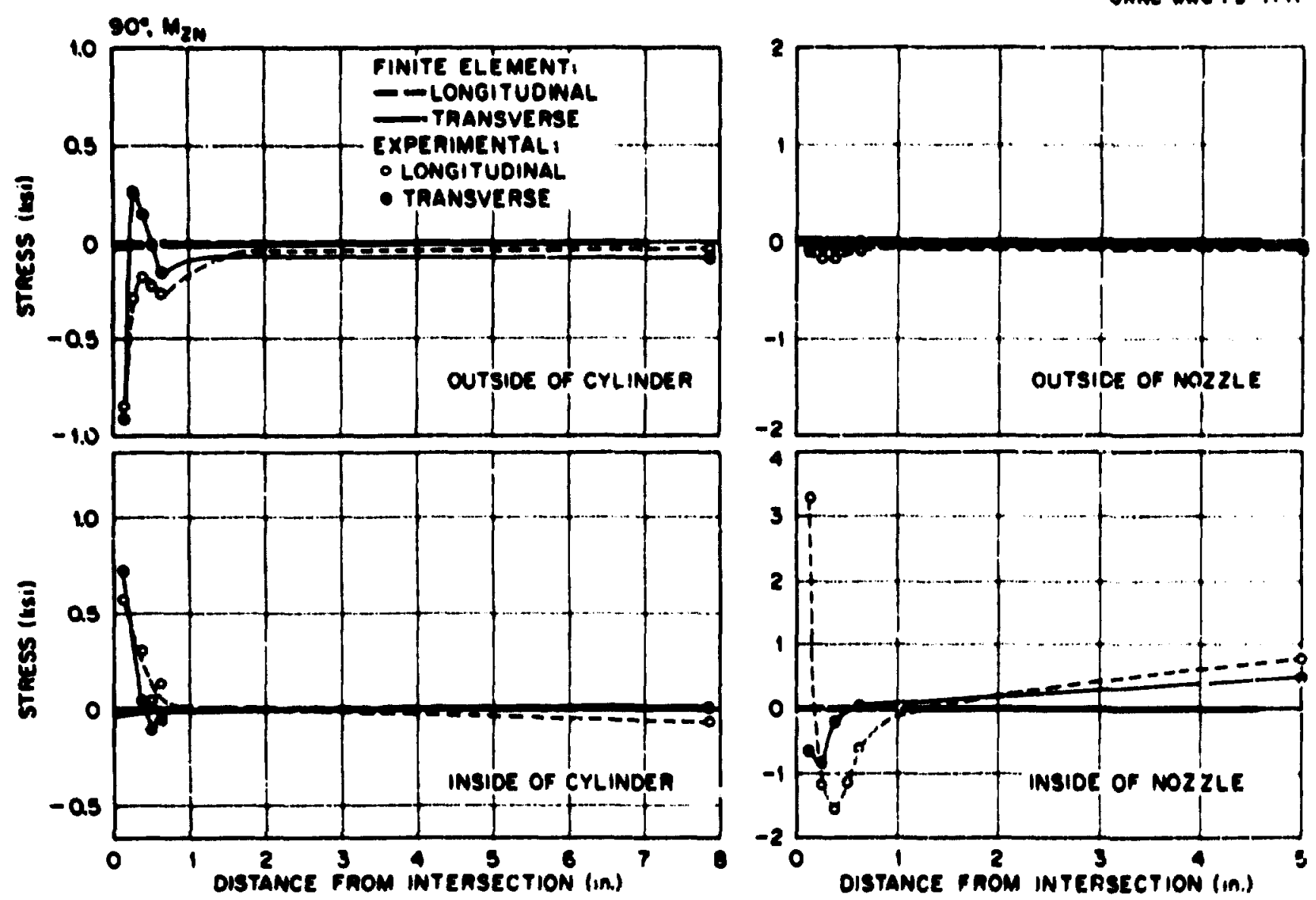

718. 44. Moasured and prodlotod otrose distributions at $90^{\circ}$ for 1nplapo momont, $M_{2 y y}$ on poselo. 

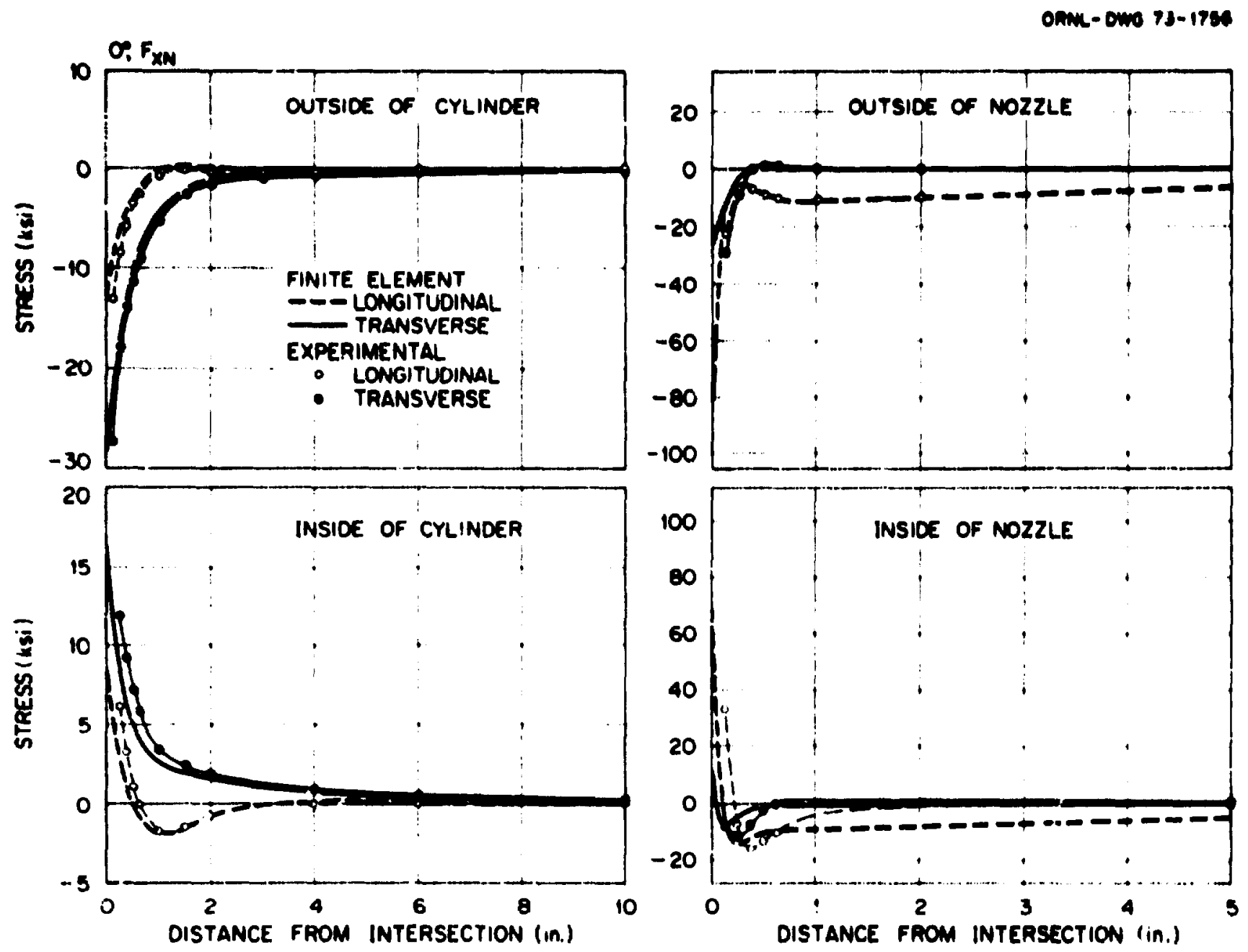

F18. 45. Measured and predicted stress diatributions at $0^{\circ}$ for inplane force, b' $\mathrm{xw}$ ' on noszle. 

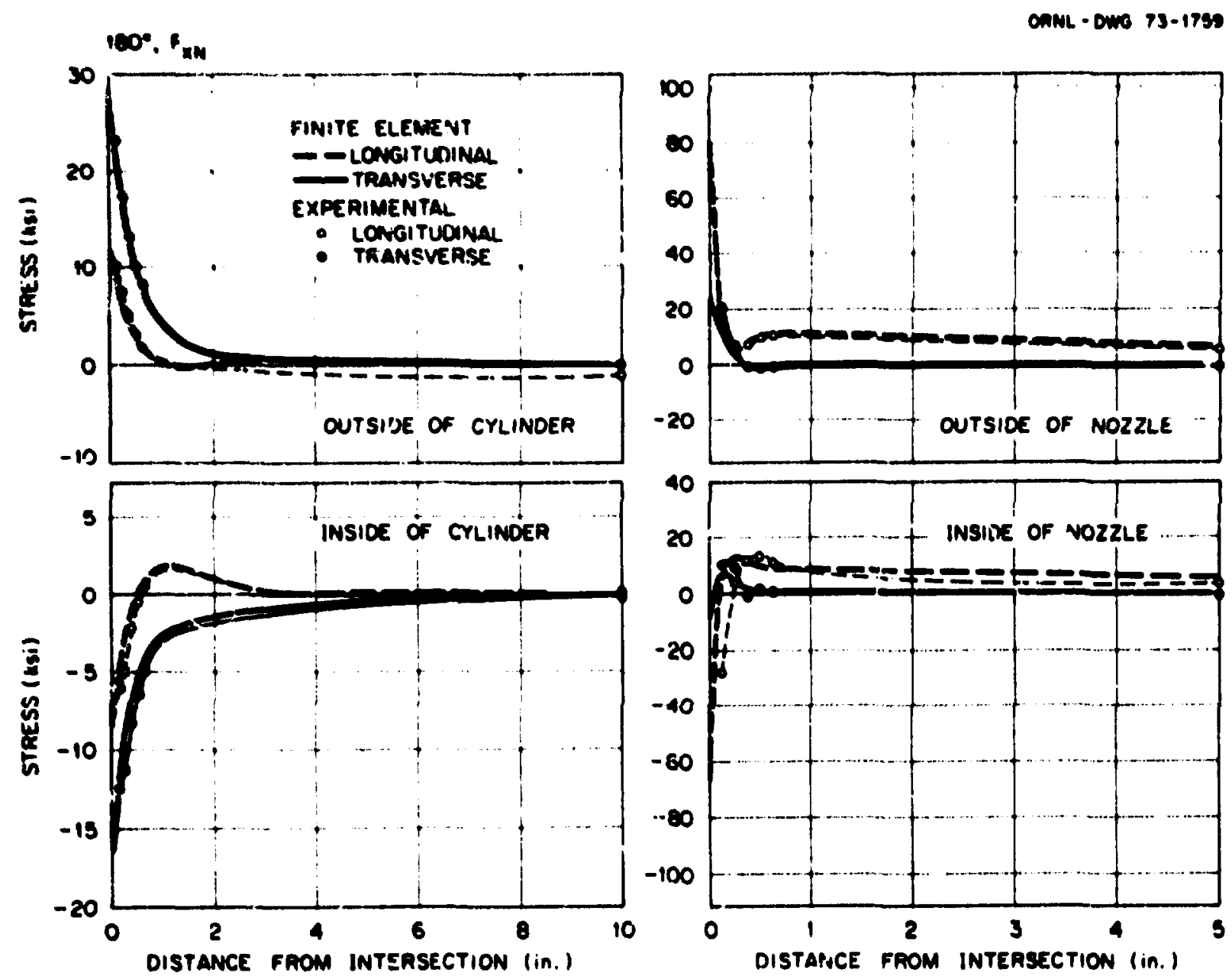

I16. 46. Masmurad and prodicted atrose distribut1ons at $280^{\circ}$ for 1n-plane saree, Frat on noszio. 

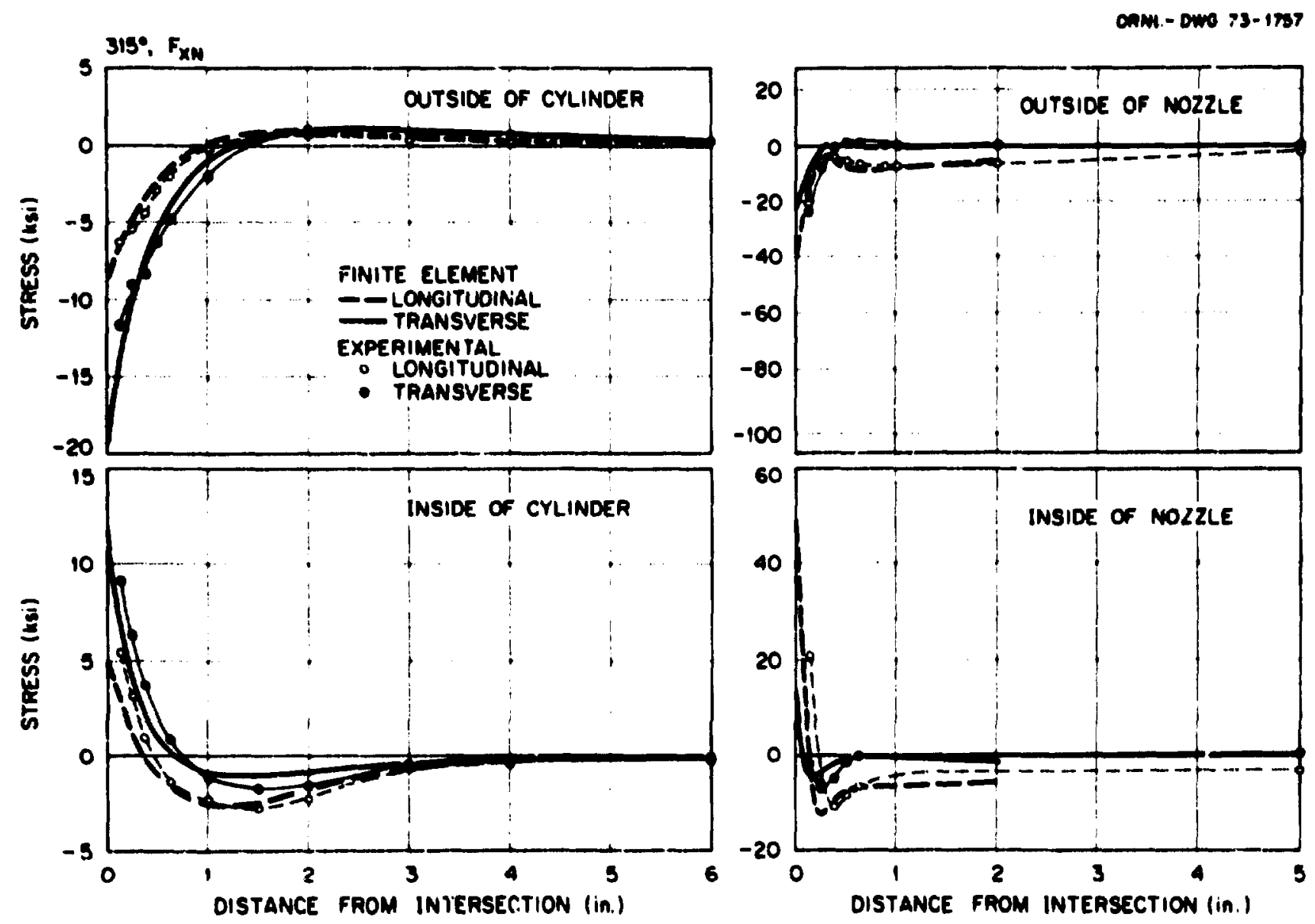

F18. 47. Nasured and predioted stress distributions at $315^{\circ}$ for 1'1-plane fores, Fay' an nosele. 
OAAL- DWG 73-1790
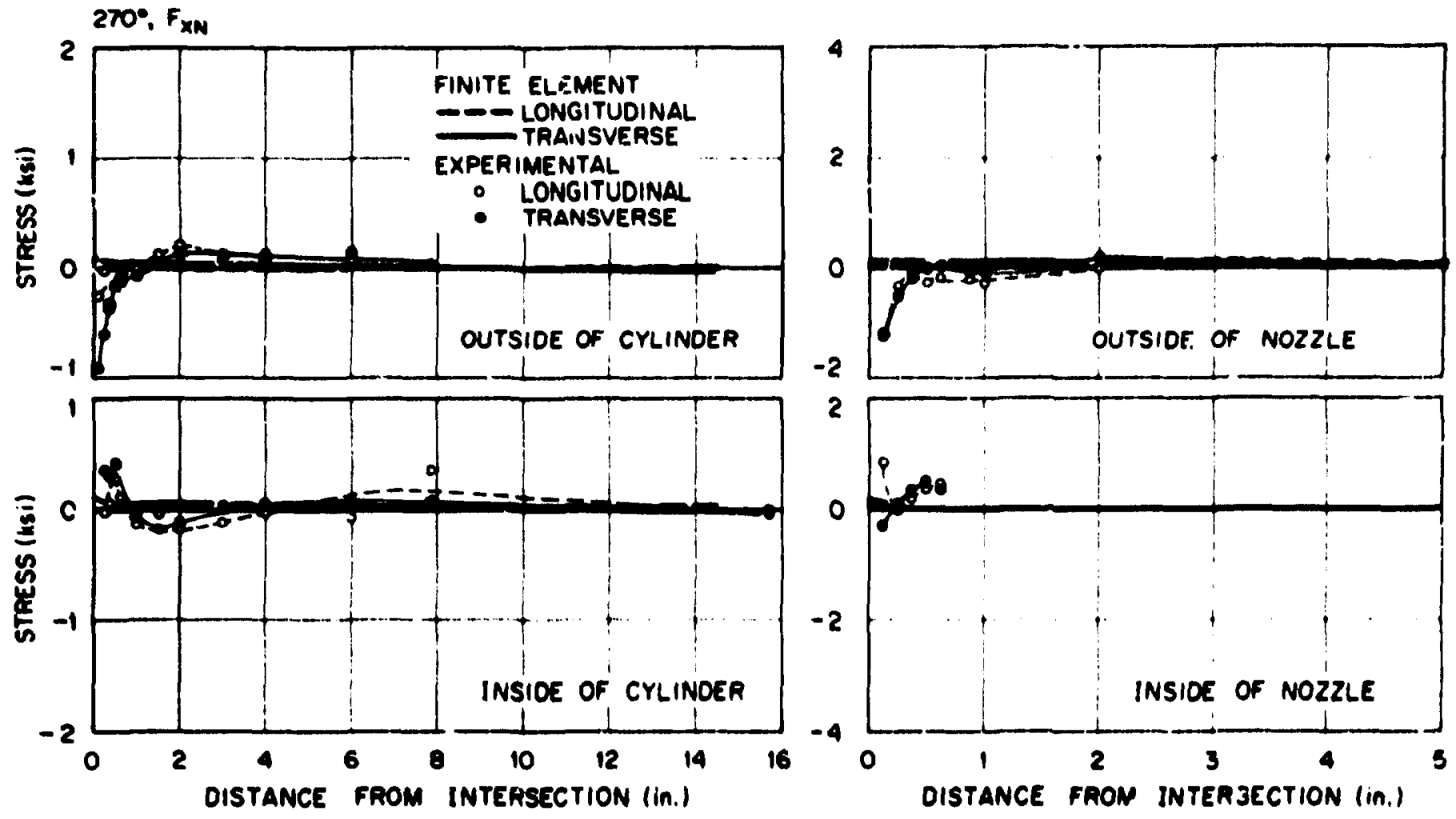

F18. 48. Mesoured and prodloted stross detributions at $270^{\circ}$ for in-plane soroe, $F_{X j}$, on noselo. 

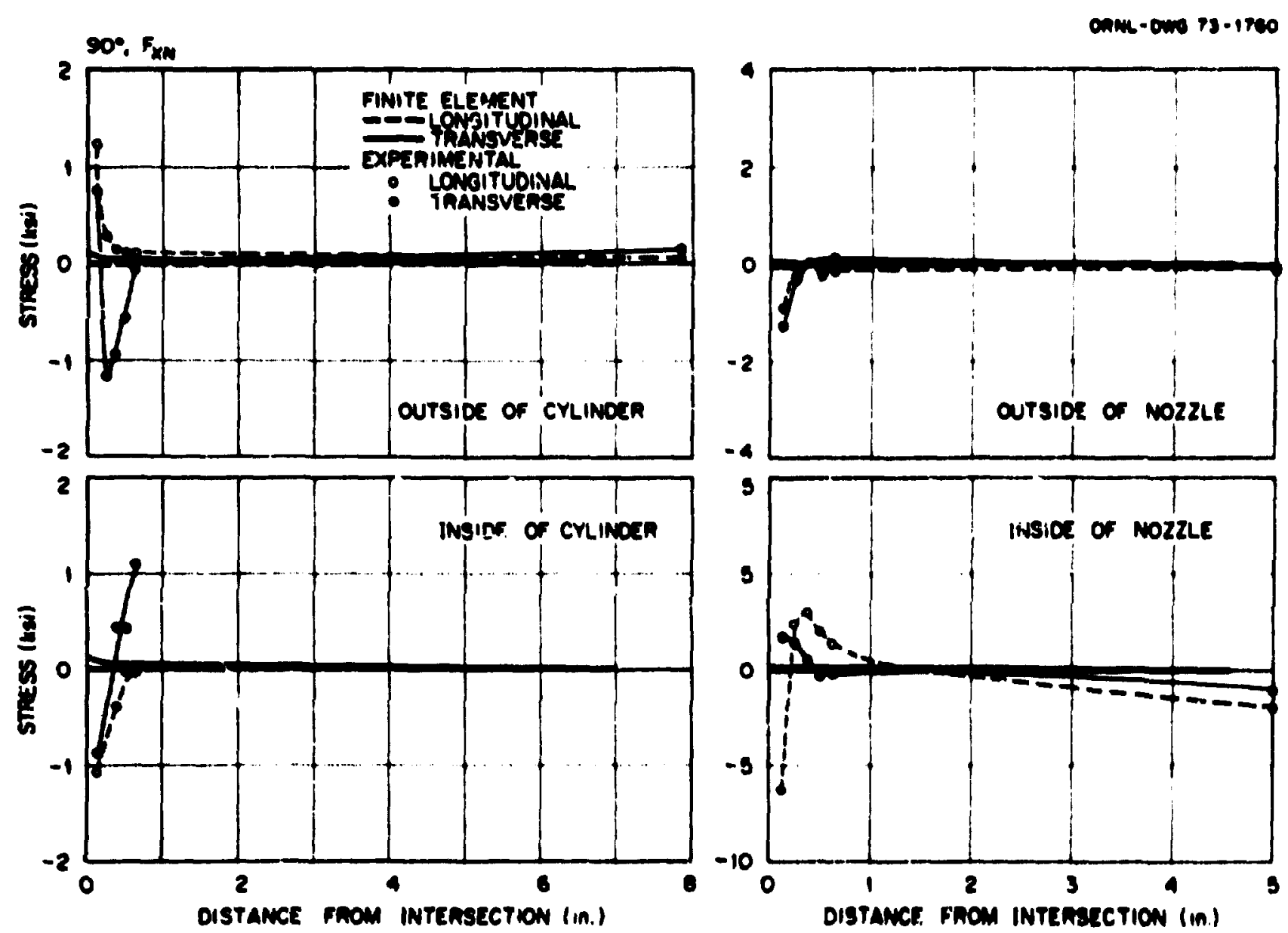

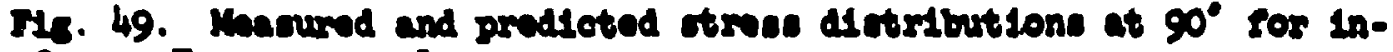
plane foree, Tyer, on noselo. 

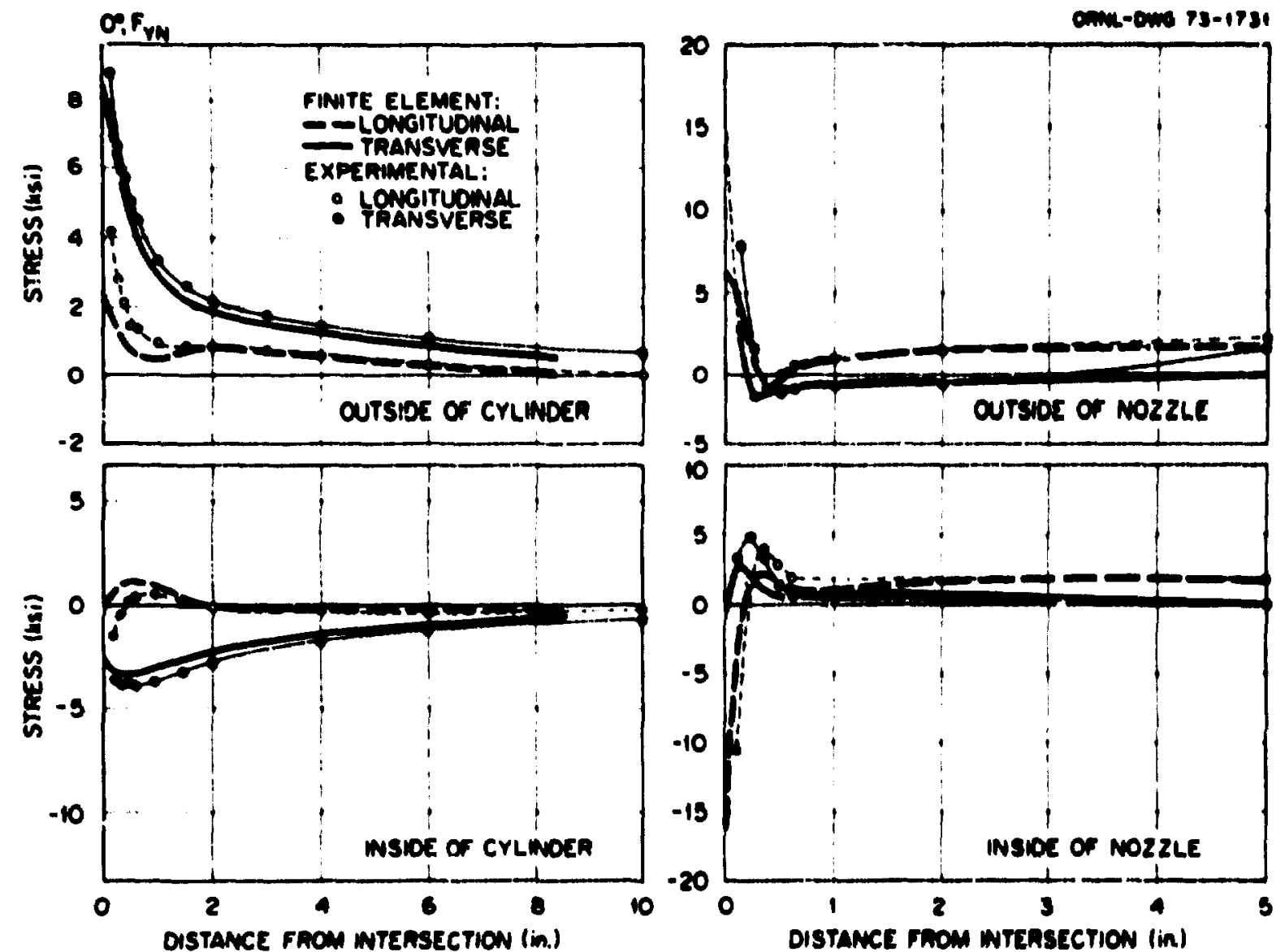

Fic. 50. Meanured and predleted atrese distributione at $0^{\circ}$ for axinl foree, $F_{Y,}$, on nosule. 

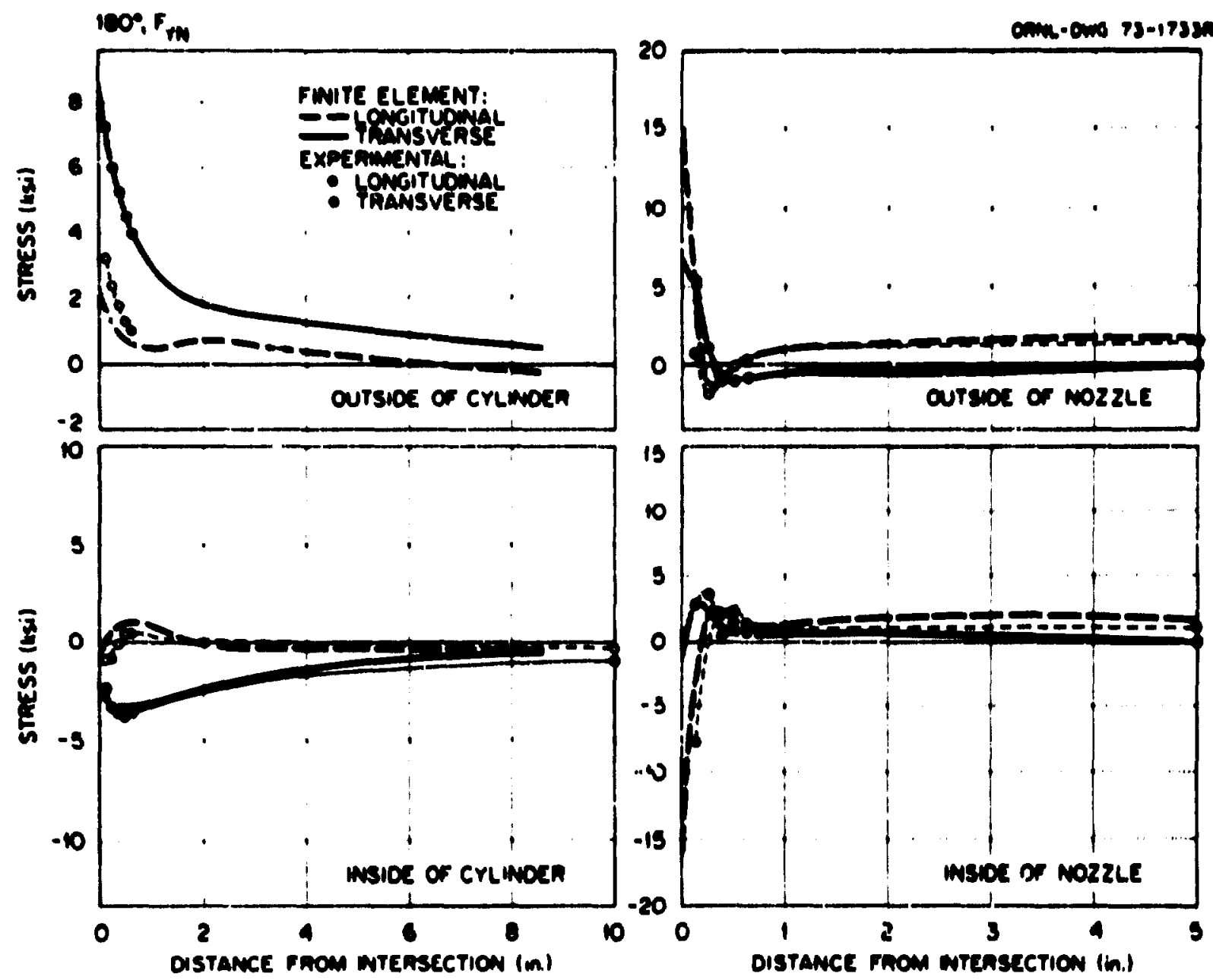

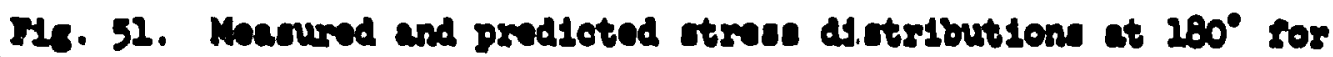
axtel foroe, Fry, on nossle. 

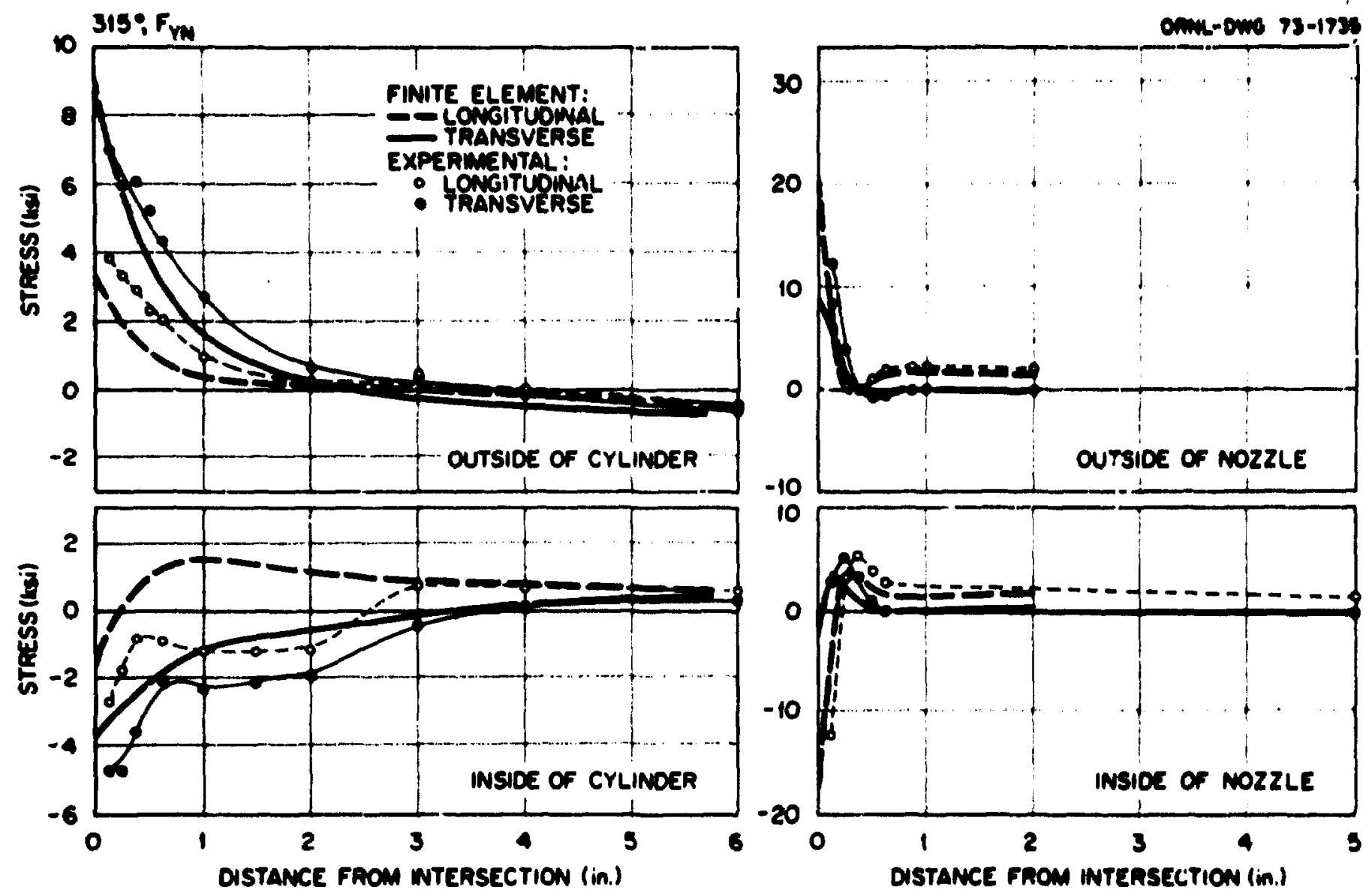

F15. 52. Honoured and prodloted streas distributione at $325^{\circ}$ for axtal soree, Fin, on nosele. 

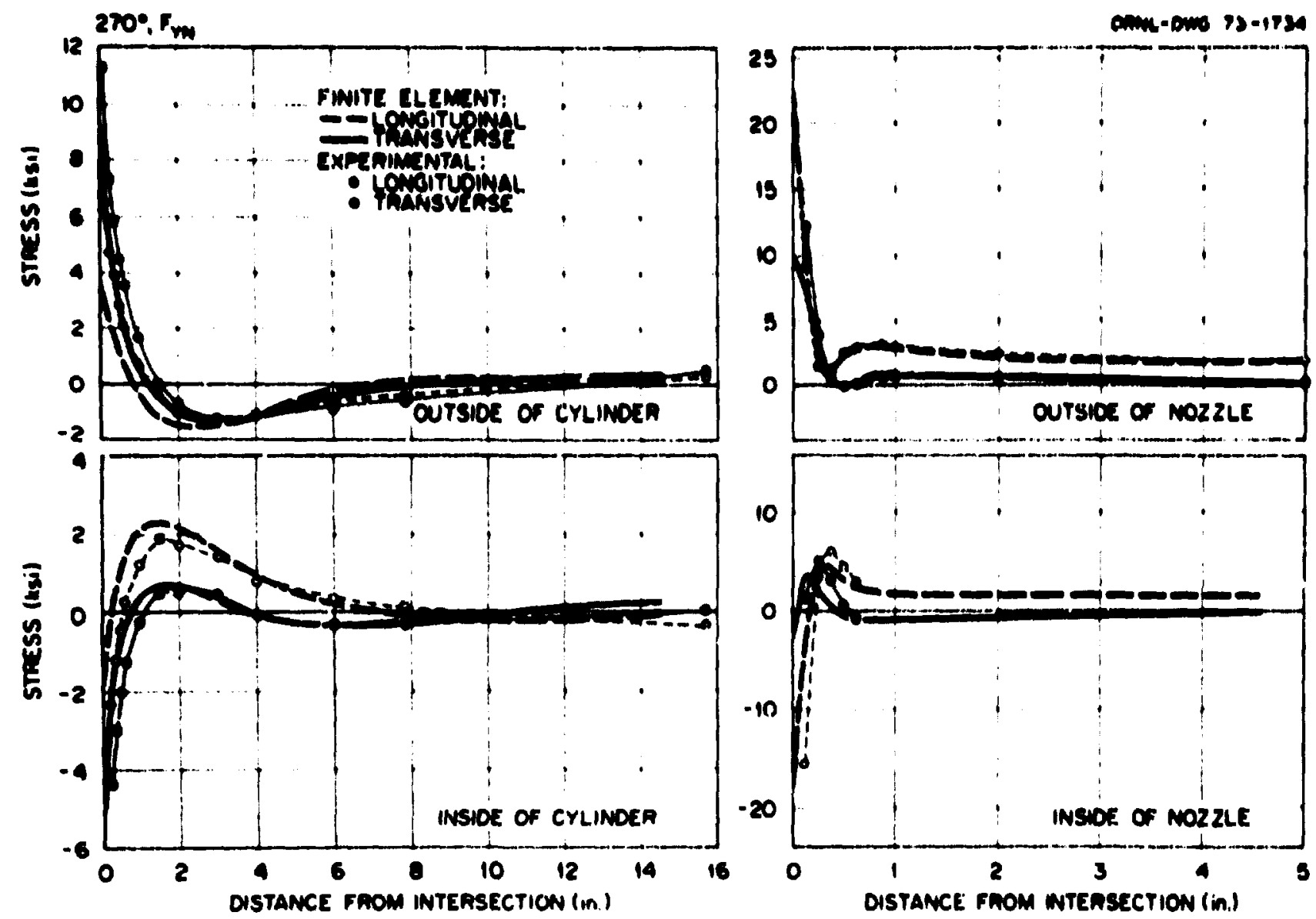

F18. 53. Messured and predicted stress distributions at $270^{\circ}$ for exdel foree, F YXX , on nosele. 

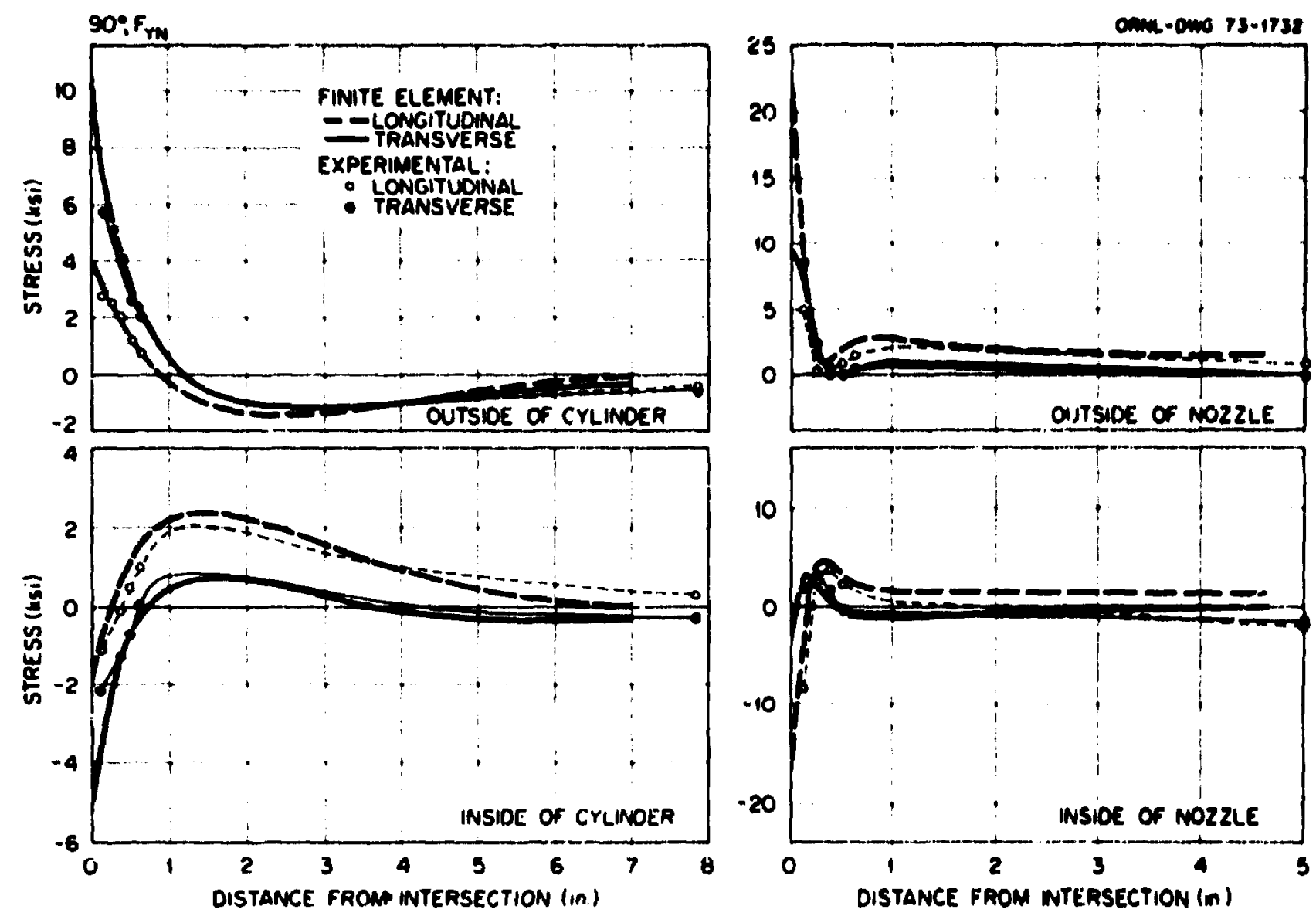

F16. 54. Measured and predicted atrose distributions at $90^{\circ}$ for axial force, $F_{\text {YN }}$ on nossie. 

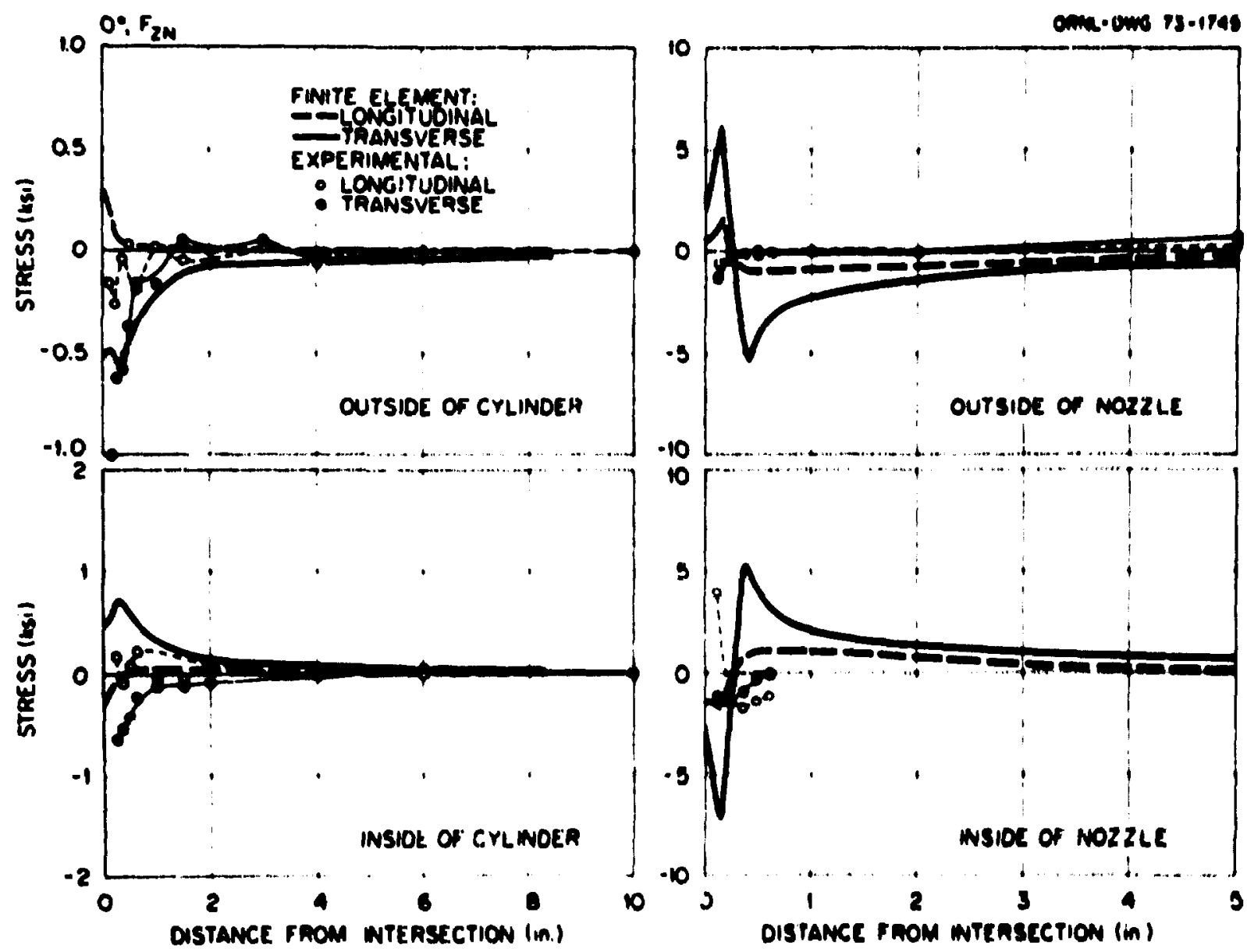

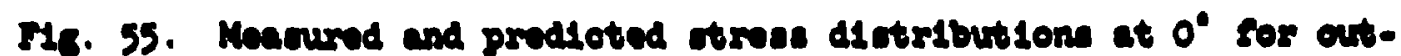
or-plane sores, $F_{21}$, on nosele. 

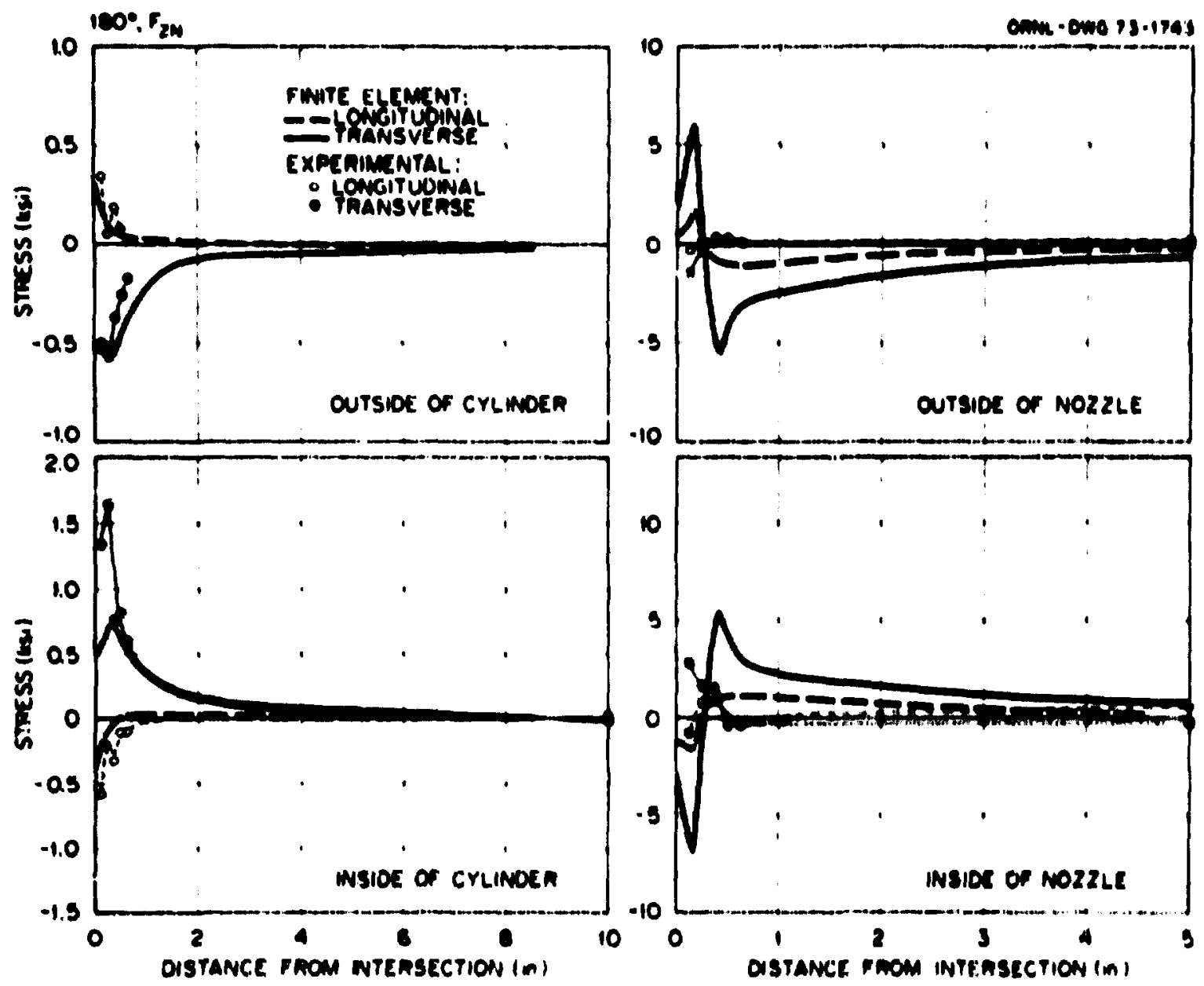

Mg. 56. Measured and prodsoted atrens distributions at $200^{\circ}$ sor out-or-plane soroo, $\mathbf{T}_{\mathrm{zy}}$, on nosale. 

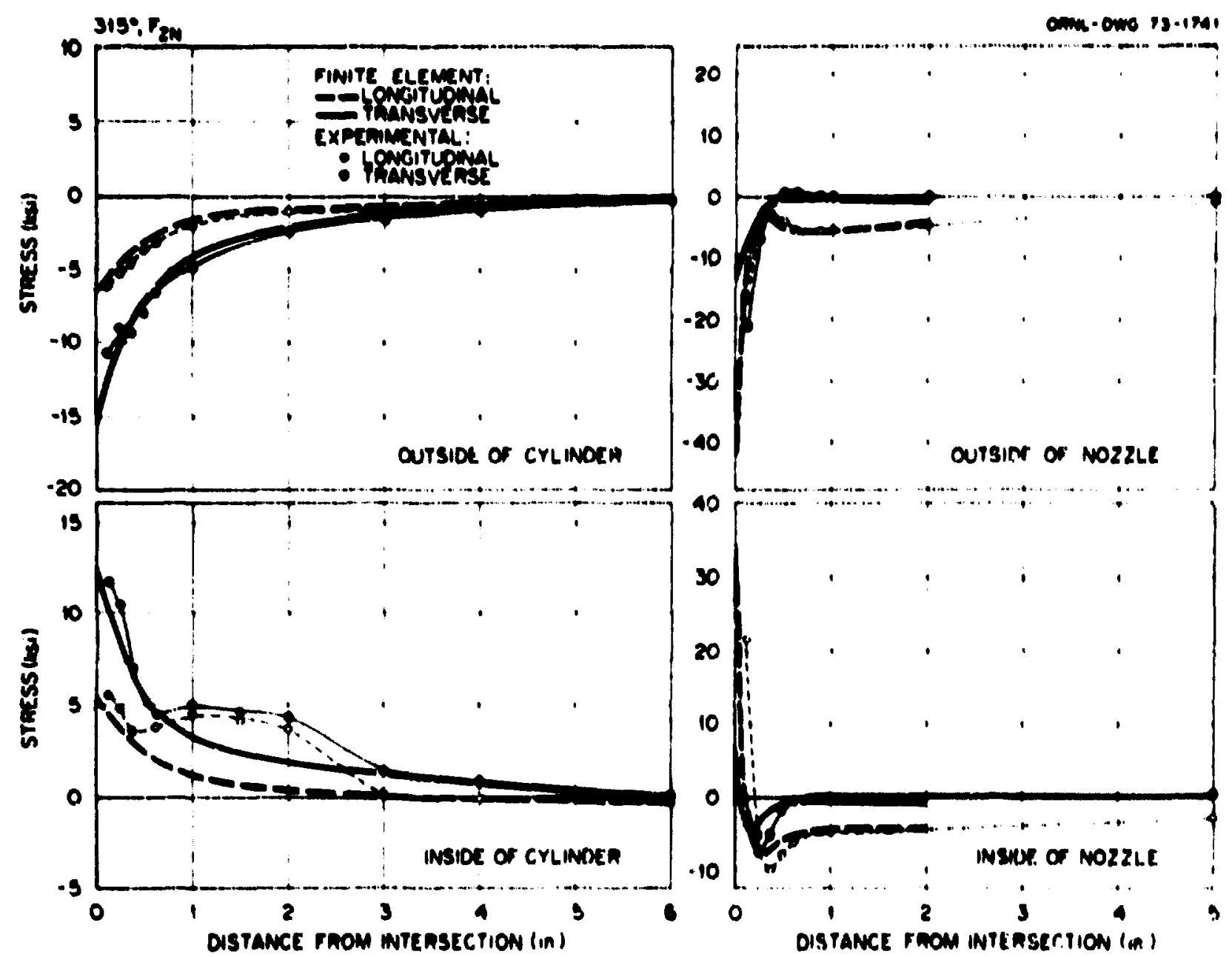

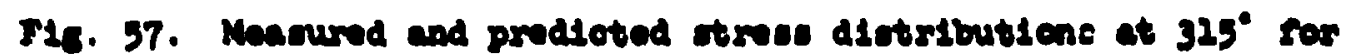

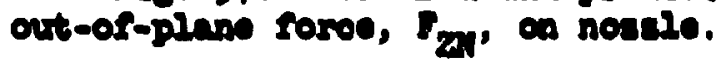



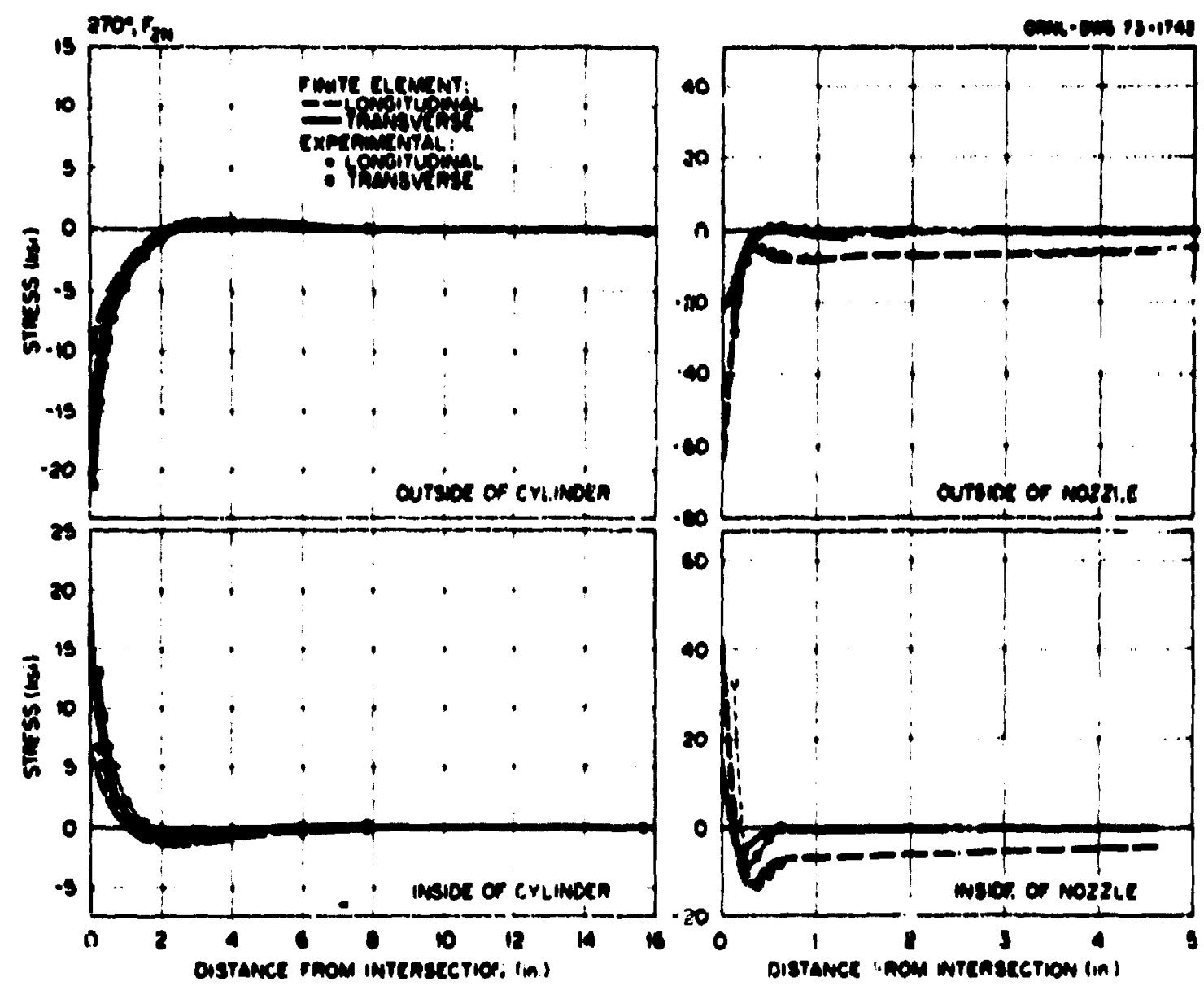

T4. 58. Masured and prodioted otroes distributione at $270^{\circ}$ ros out-of-plane foroo, $z_{2 y p}$, on noselo. 

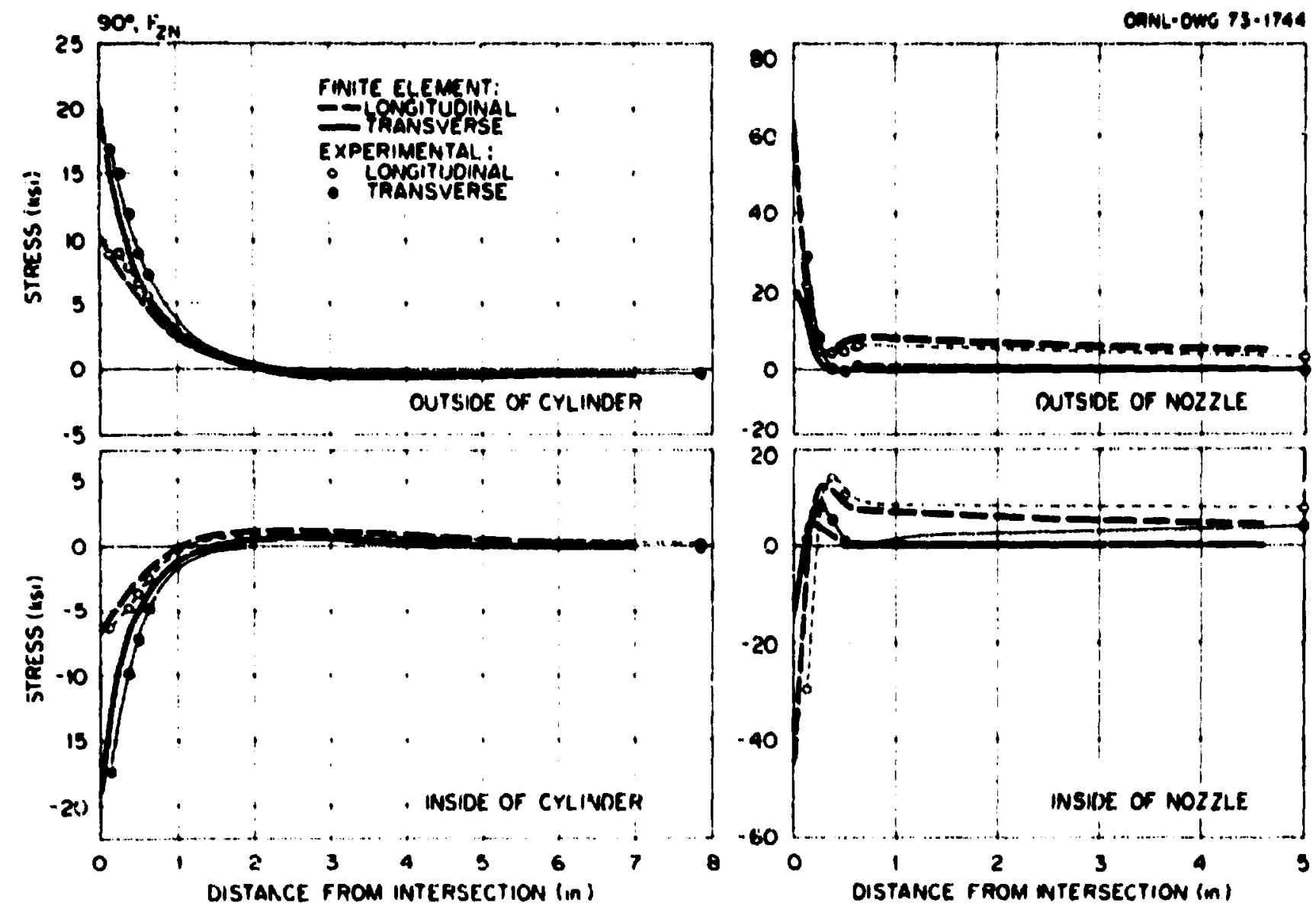

M6. 59. Moanured and prodloted otrese distributions at $90^{\circ}$ sor out-or-plane rorce, $F_{2 N}$, on nozzld. 


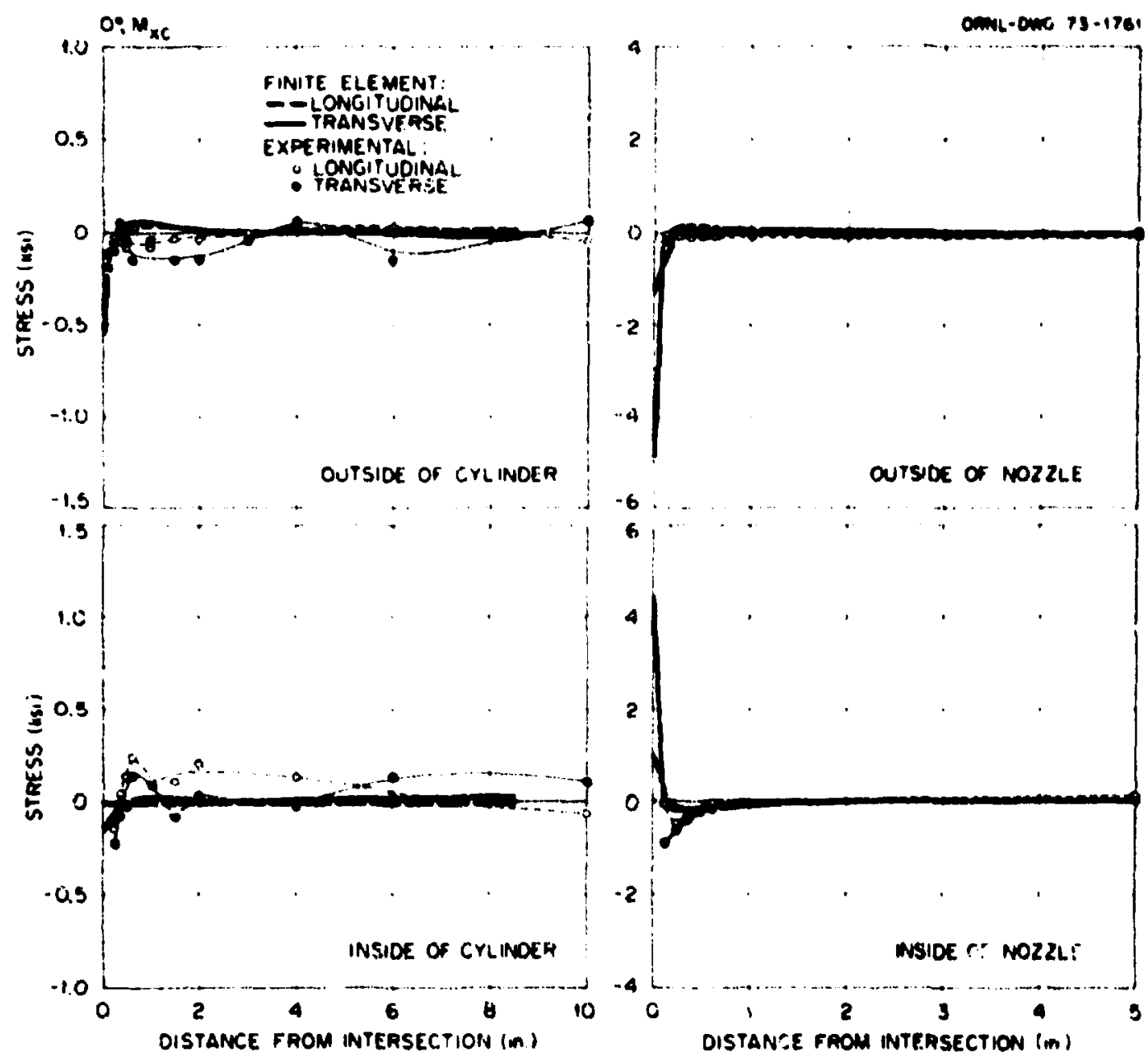

F1g. 60. Meacured and predicted atress distributions at $0^{\circ}$ for torslonal monont, ${ }_{X C}$, on cylinder. 

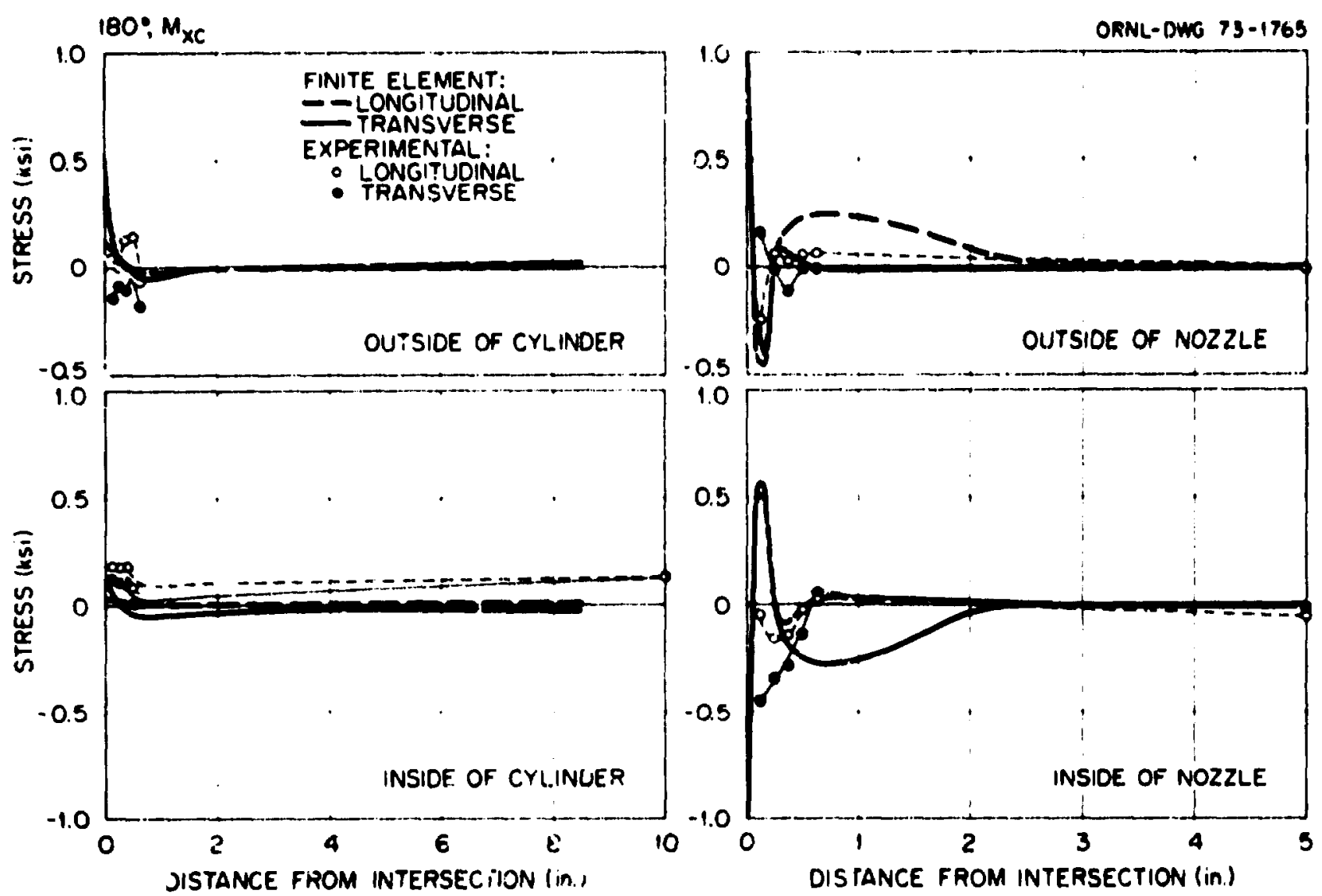

F1,7. 61. Measured and predicted stress distributions at $180^{\circ}$ for torsiona: moment, "Yx, on cylinder. 

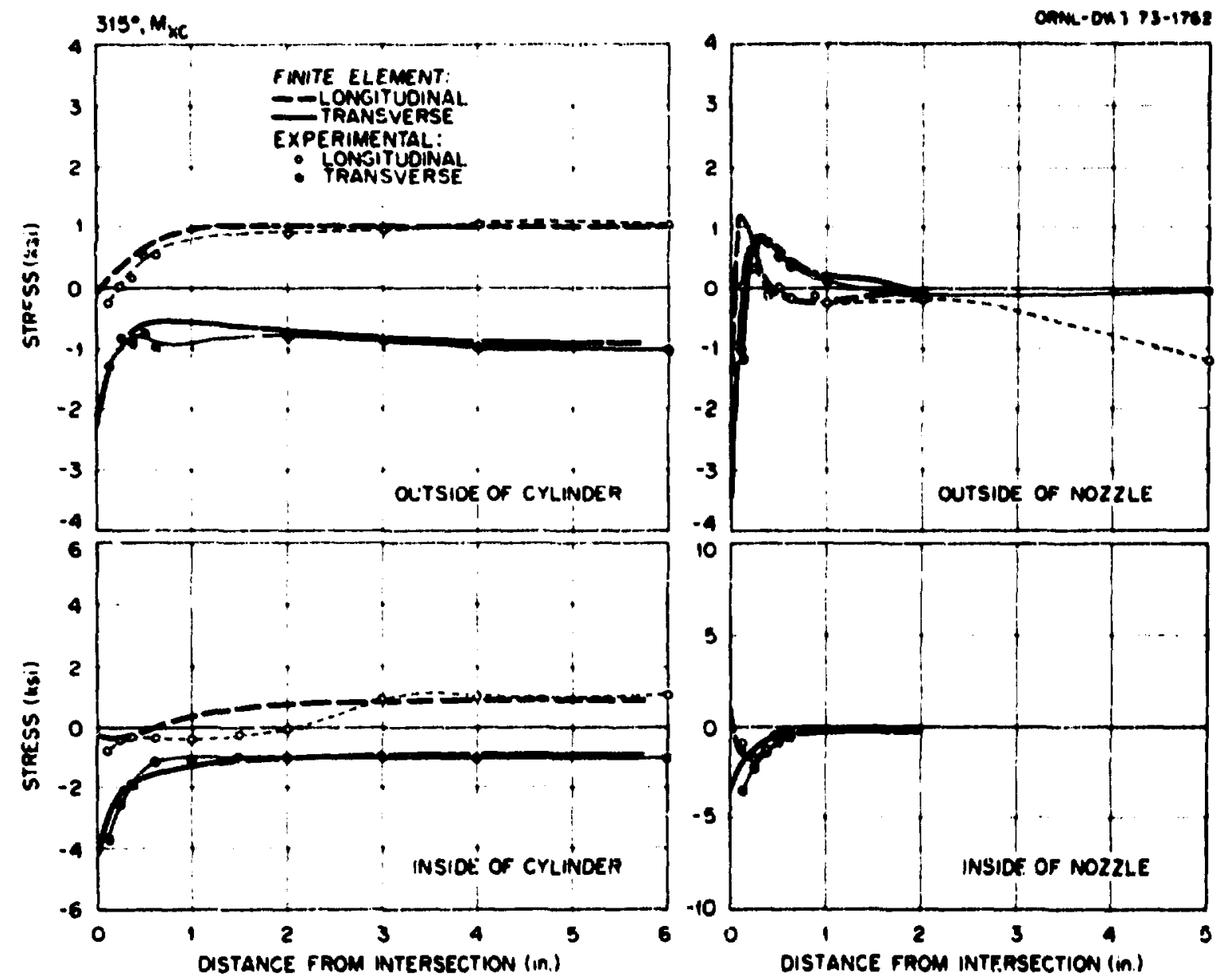

F8. 62. Moasured and predicted atrese distributions at $315^{\circ}$ for torelonal moment, 'MC' on cylinder. 

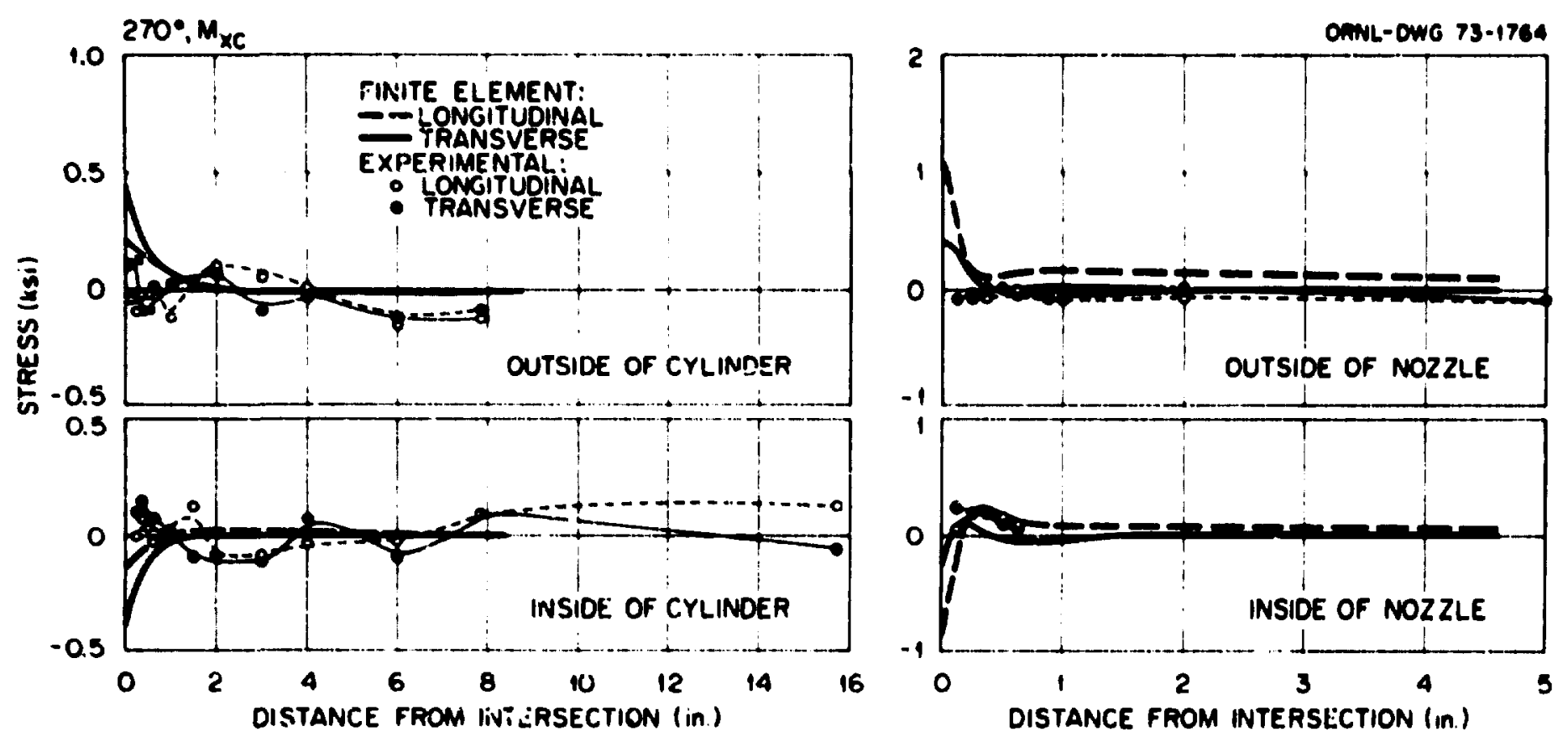

Fig. 63. Masured and predloted stress distributions at $270^{\circ}$ for torsional roment, $M$, on cyllncier. 

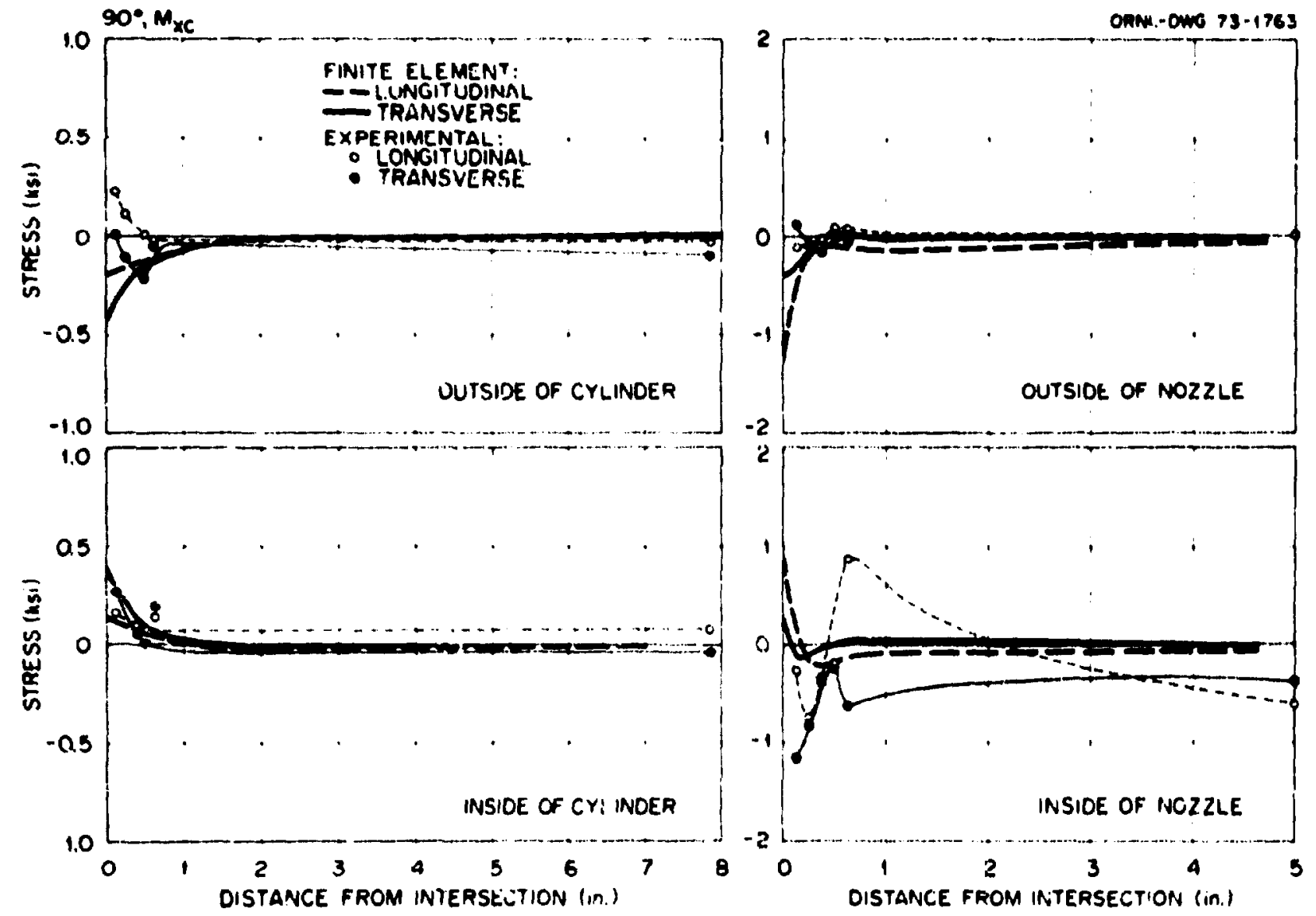

Fig. 64. Measured and predicted stress distributions at $90^{\circ}$ for torsional moment, 'MC' on cylinder. 

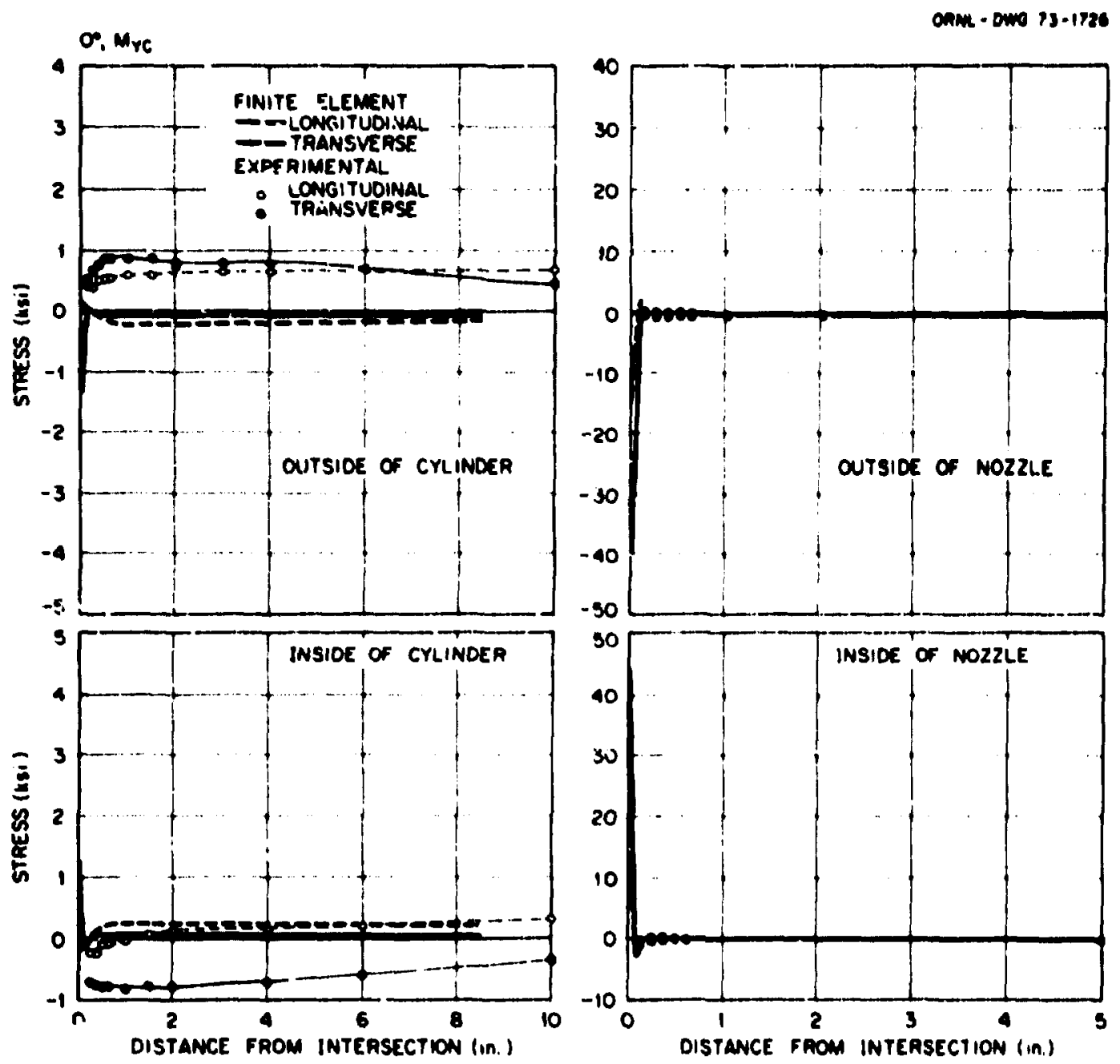

F16. 65. Measured and predicted stress distributions at $0^{\circ}$ for outof-plane moment, MY' on cylinder. 
1600. Mrc
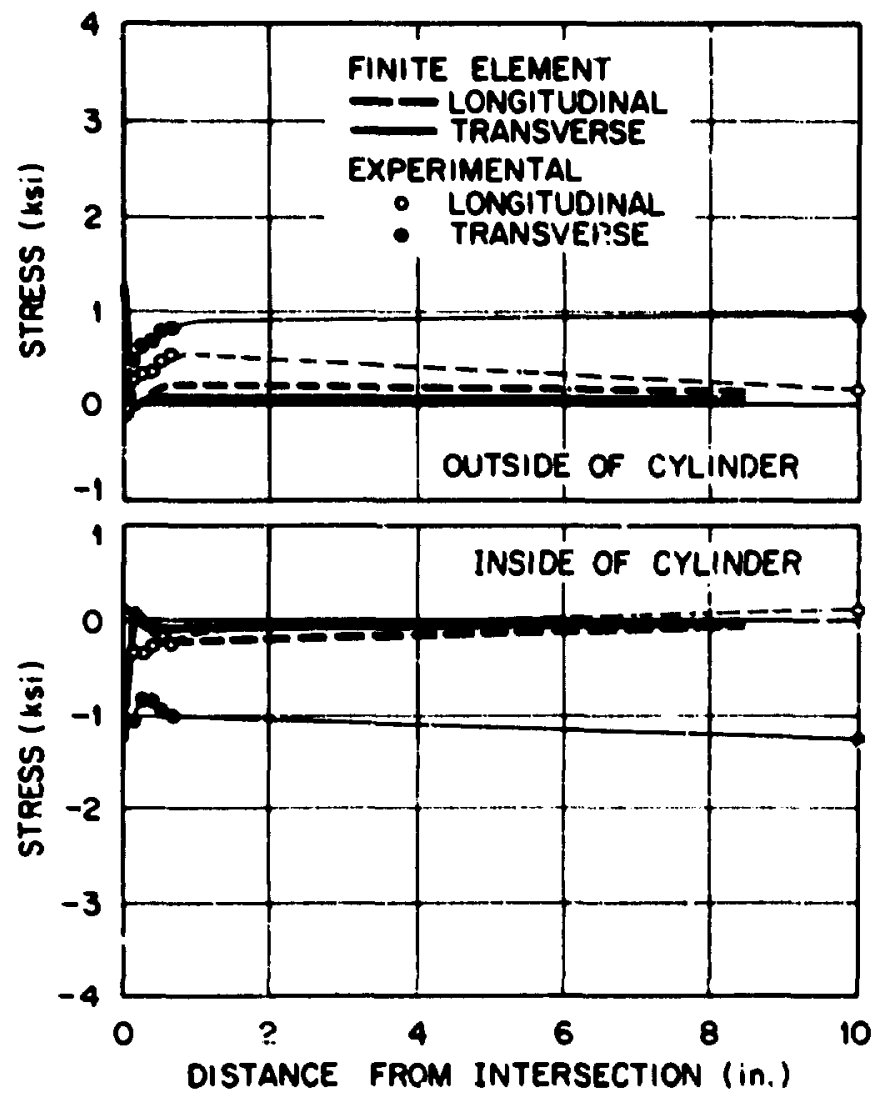
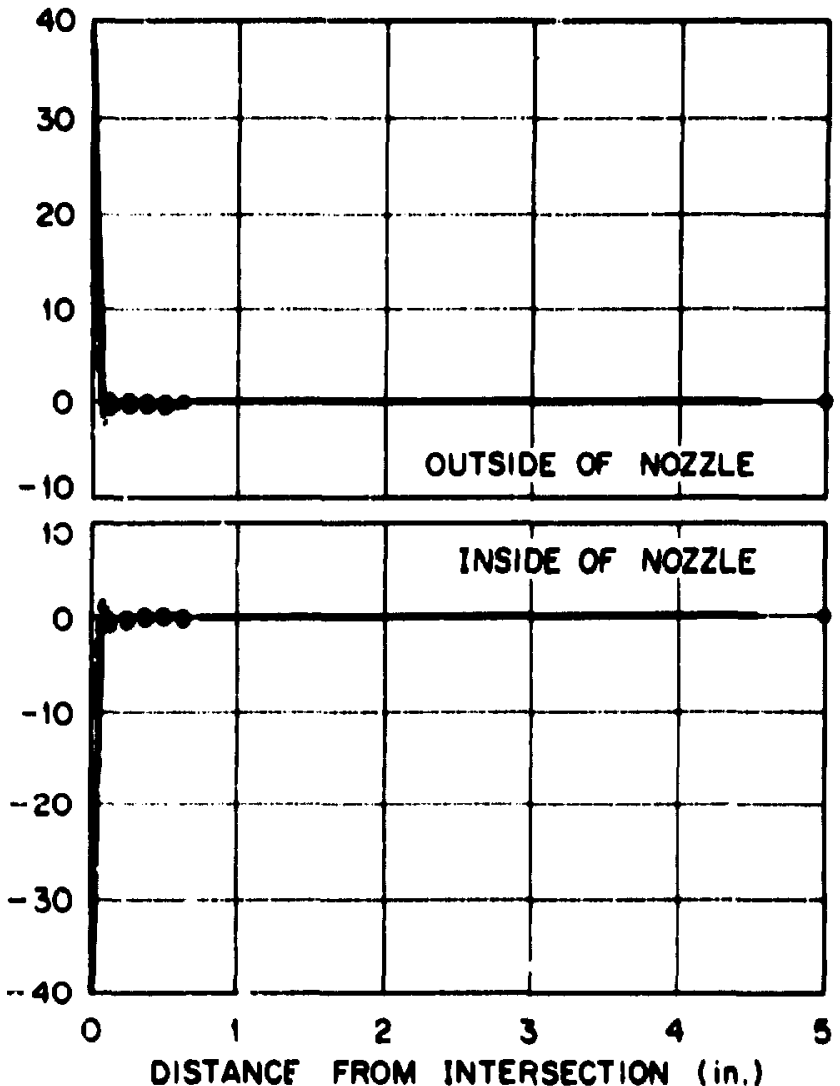

F18. 66. Measured and fredicted stross distributions at $180^{\circ}$ for

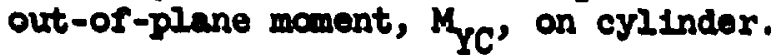



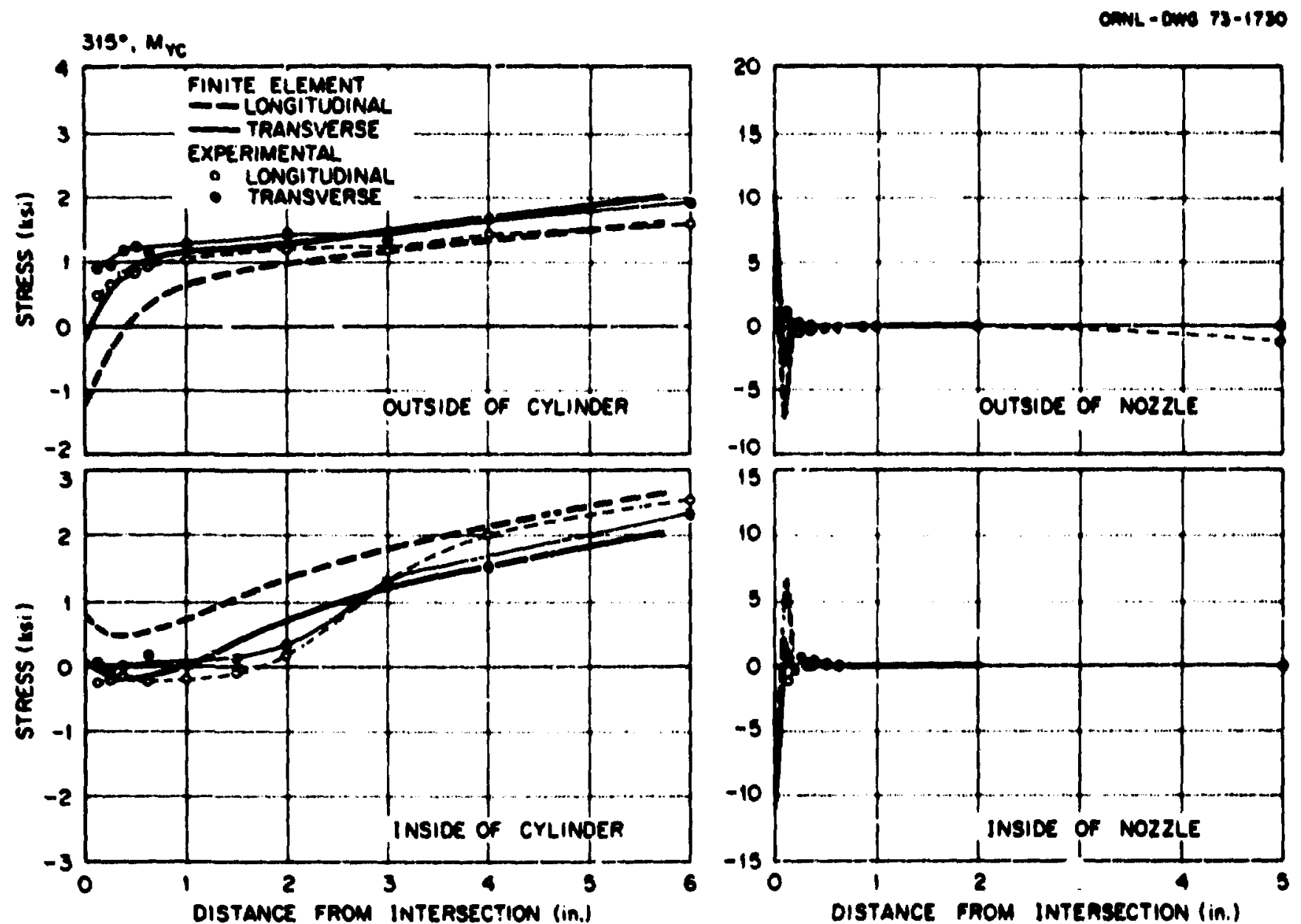

F1k. 67. Meanund and prodsoted otroes diatributione at $325^{\circ}$ for out-or-plane mowent, Mrc' on oylindar. 

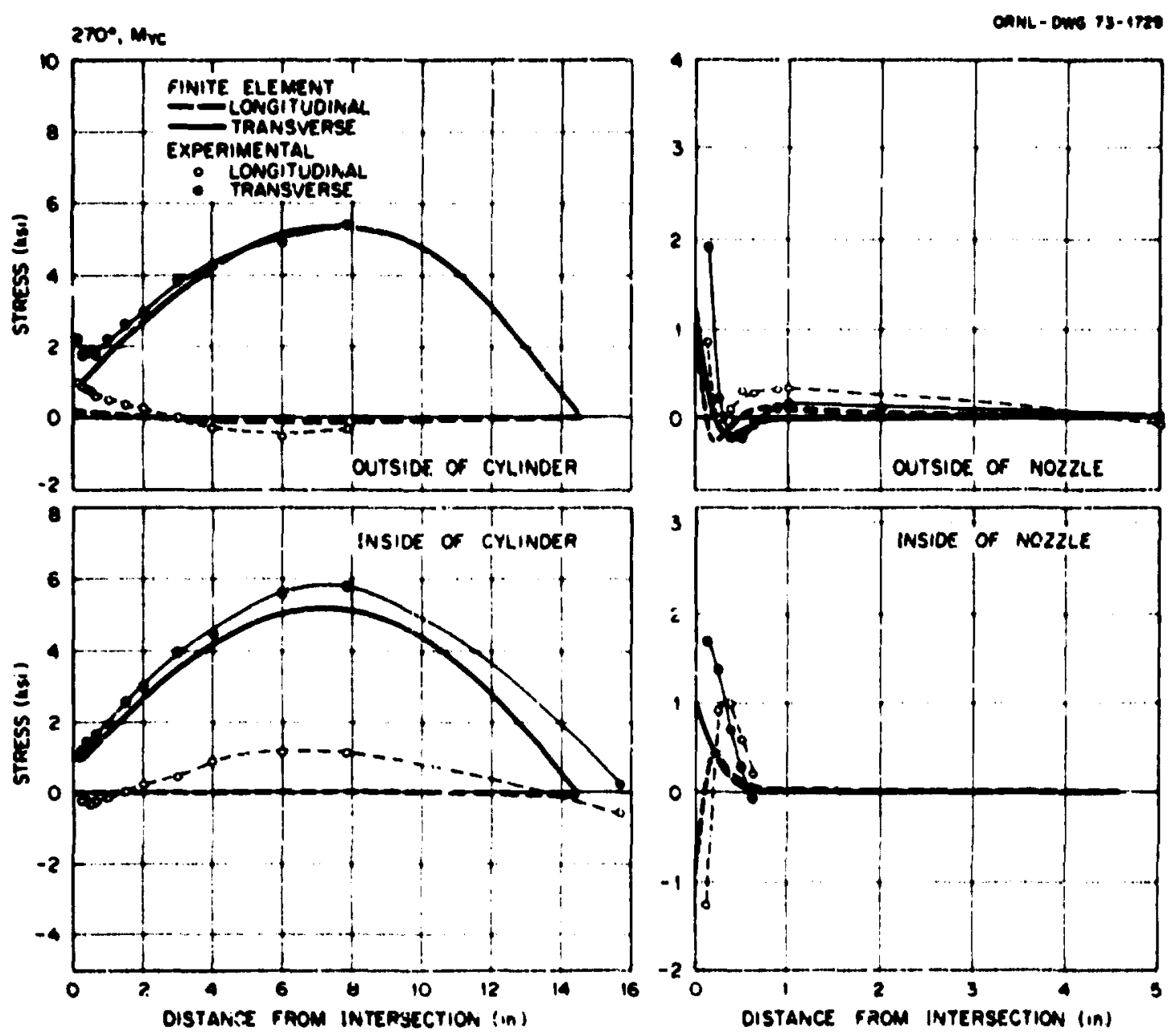

118. 68. Maneured and prodictod strose distributions at $270^{\circ}$ for out-or-plane mowent, Myc, on cylindor. 

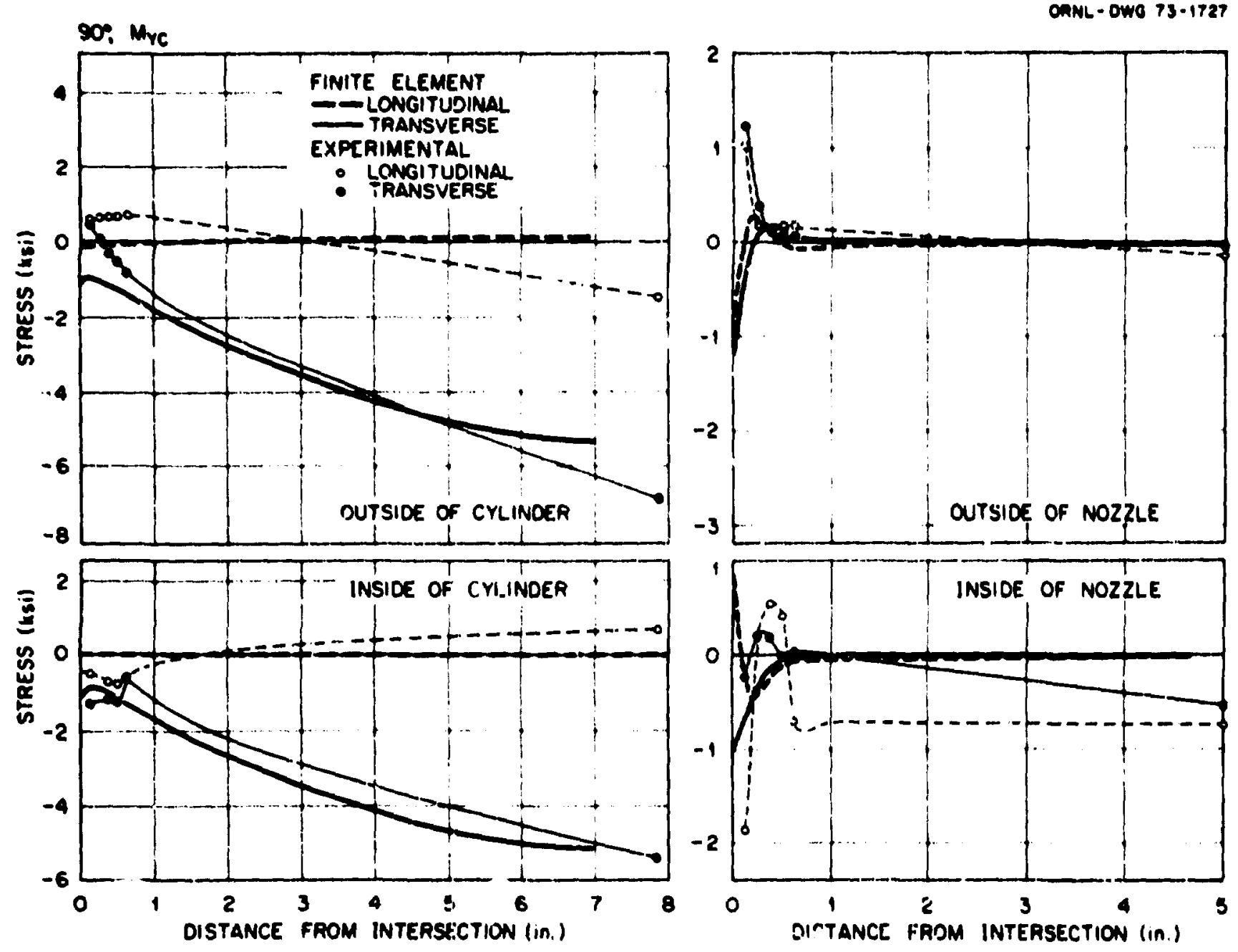

Fif. 69. Measured and predicted strese distributions at $90^{\circ}$ for out-or-plene monent, $\mathrm{YC}_{\mathrm{C}}$ on cyl1nder. 

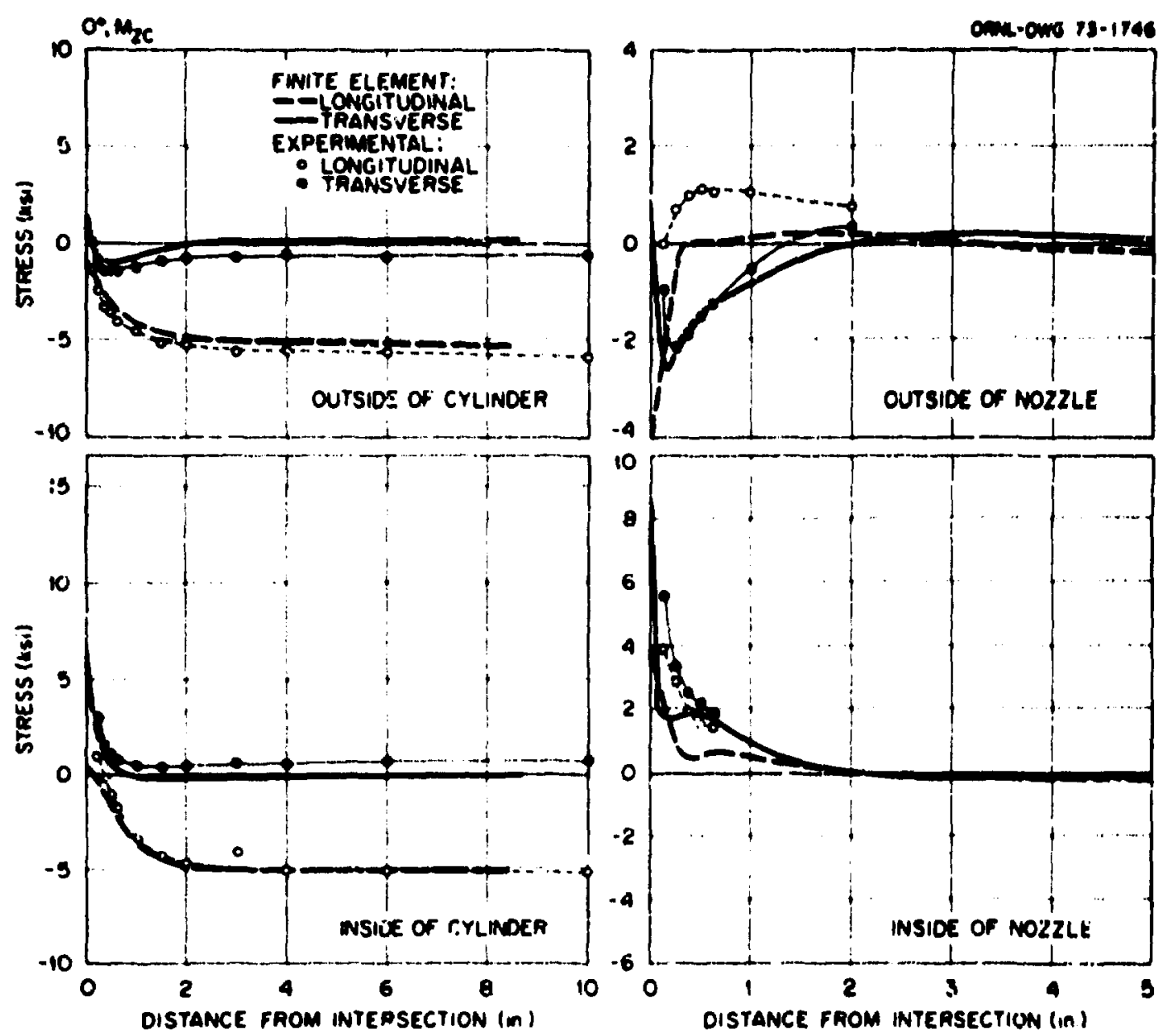

F16. 70. Measured and prodicted stross distributions at $0^{\circ}$ for Inplene monont, $\mathrm{K}_{\mathrm{ZC}}$, on cylinder. 

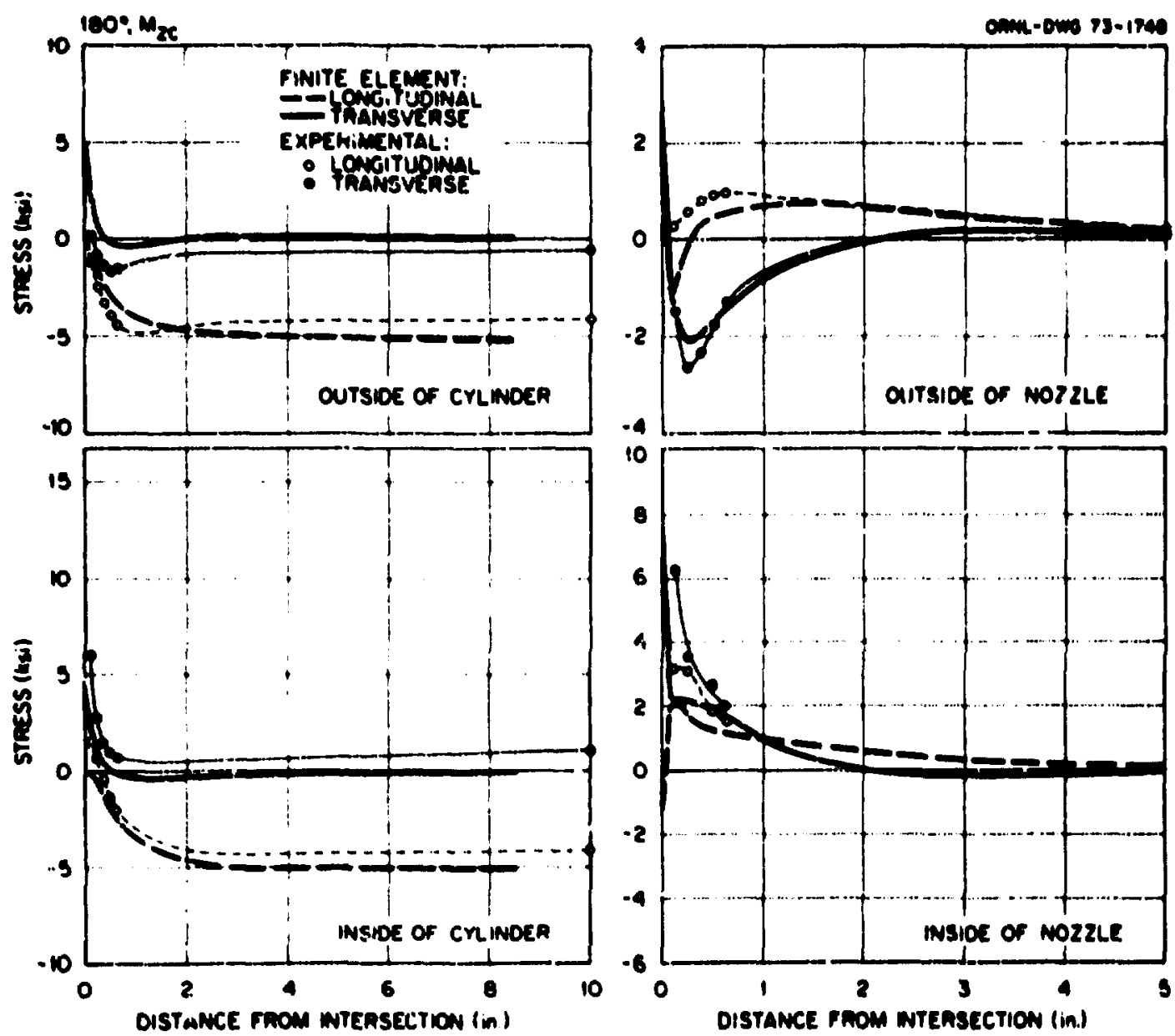

F1g. T.. Measured and predicted strass 11atributions at $180^{\circ}$ for in-plane rowent, MC' on cyilnder. 

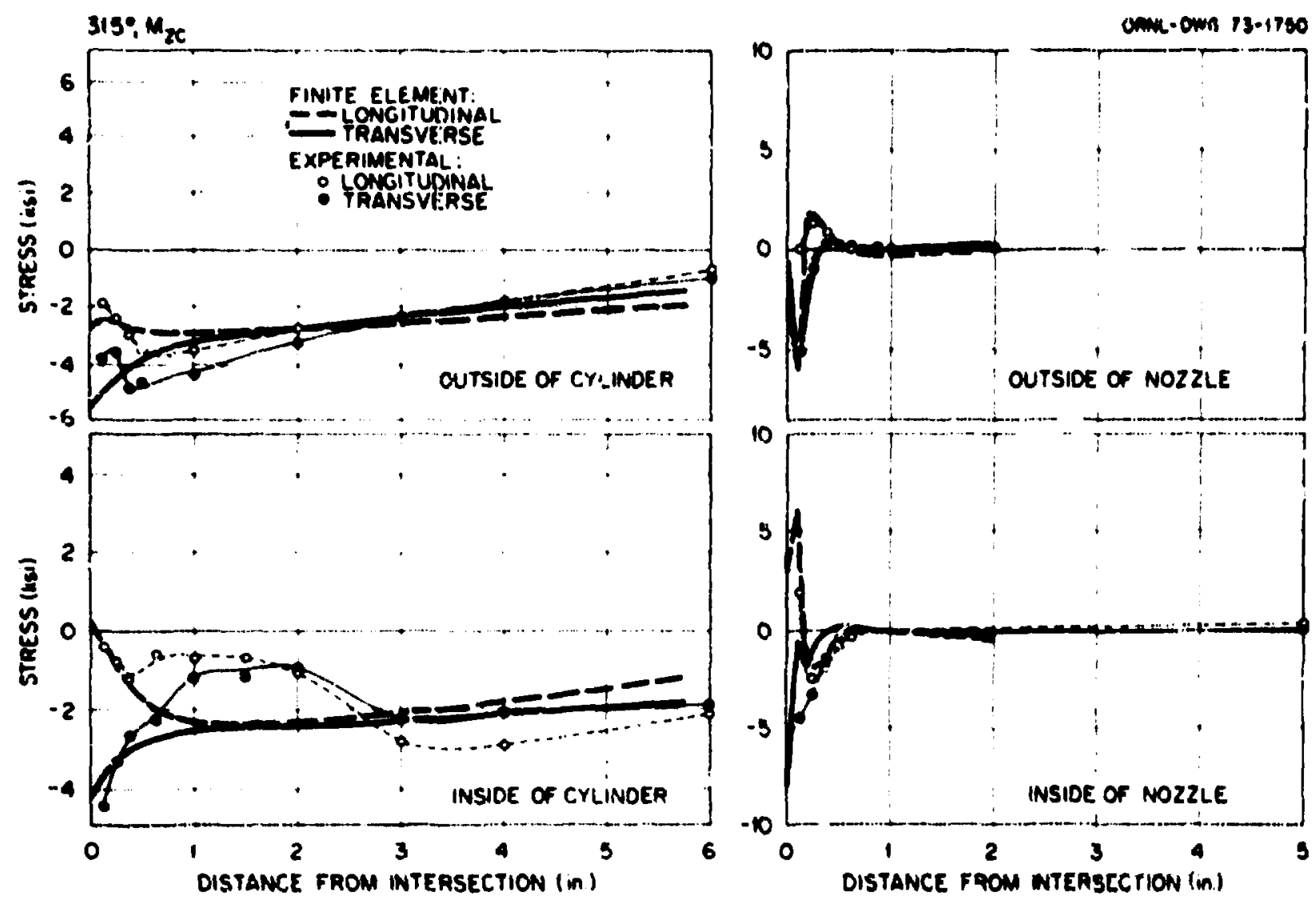

Fig. 72. Moasured and predicted etrose dietributione at $315^{\circ}$ sor In-plane moment, MC, on cylinder. 

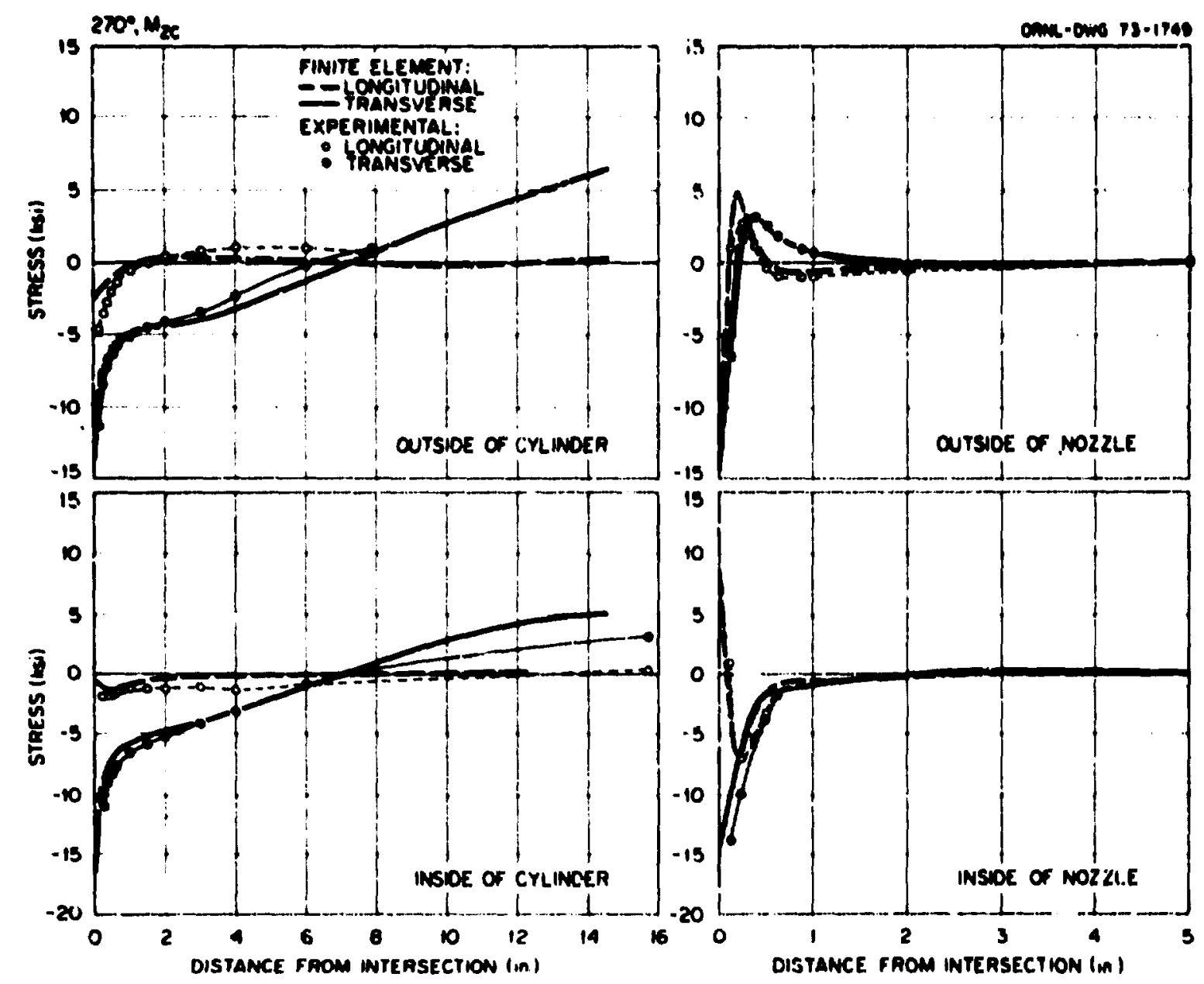

F18. 73. Measured and prodicted strose distributions at $270^{\circ}$ for in-plane manent, $\mathrm{K}_{2 C}$, on cylinder. 

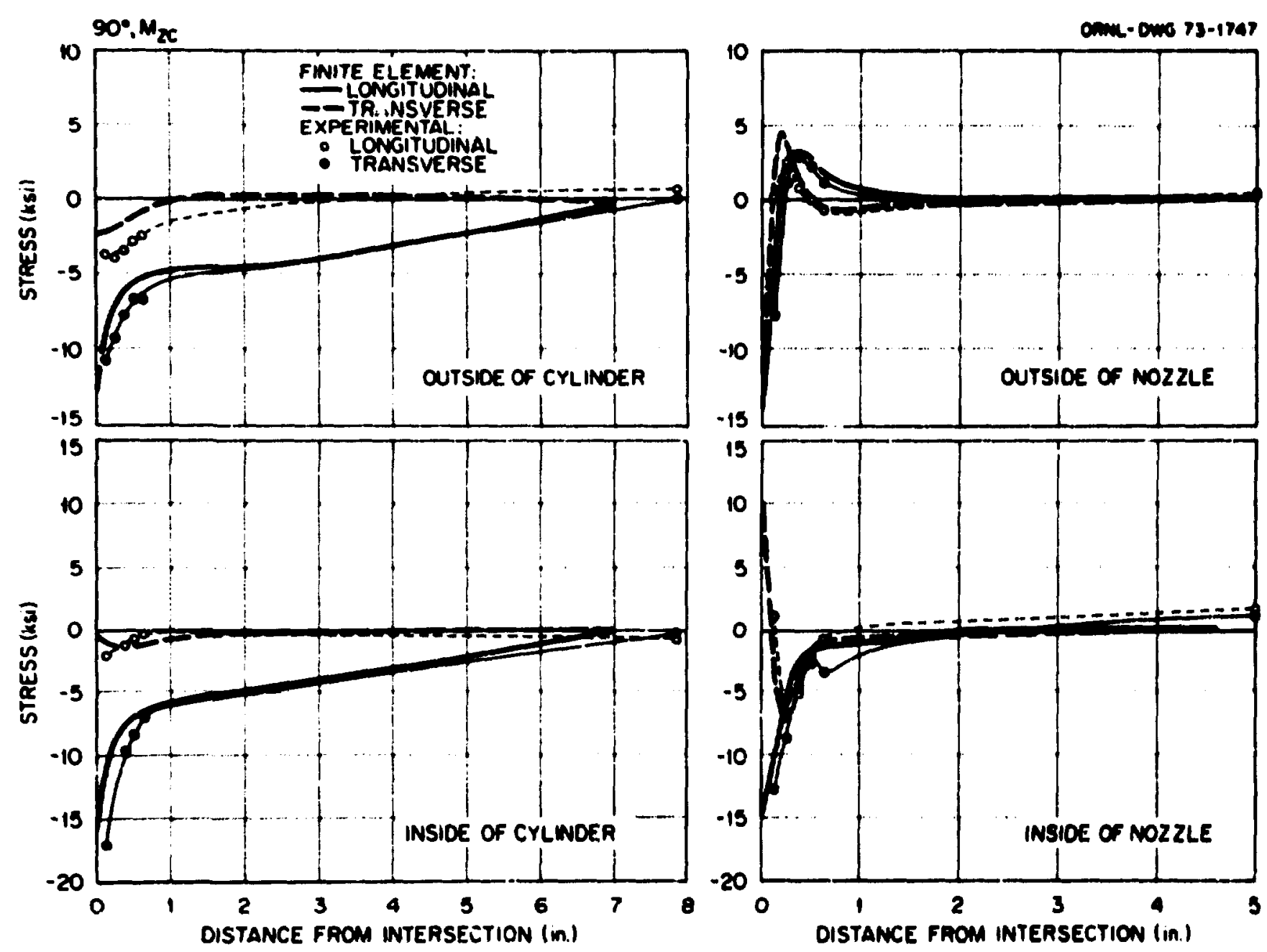

F18. 74. Measured and prodicted stress distribution at $90^{\circ}$ for inplane monent, $K_{Z C}$, on cylinder. 

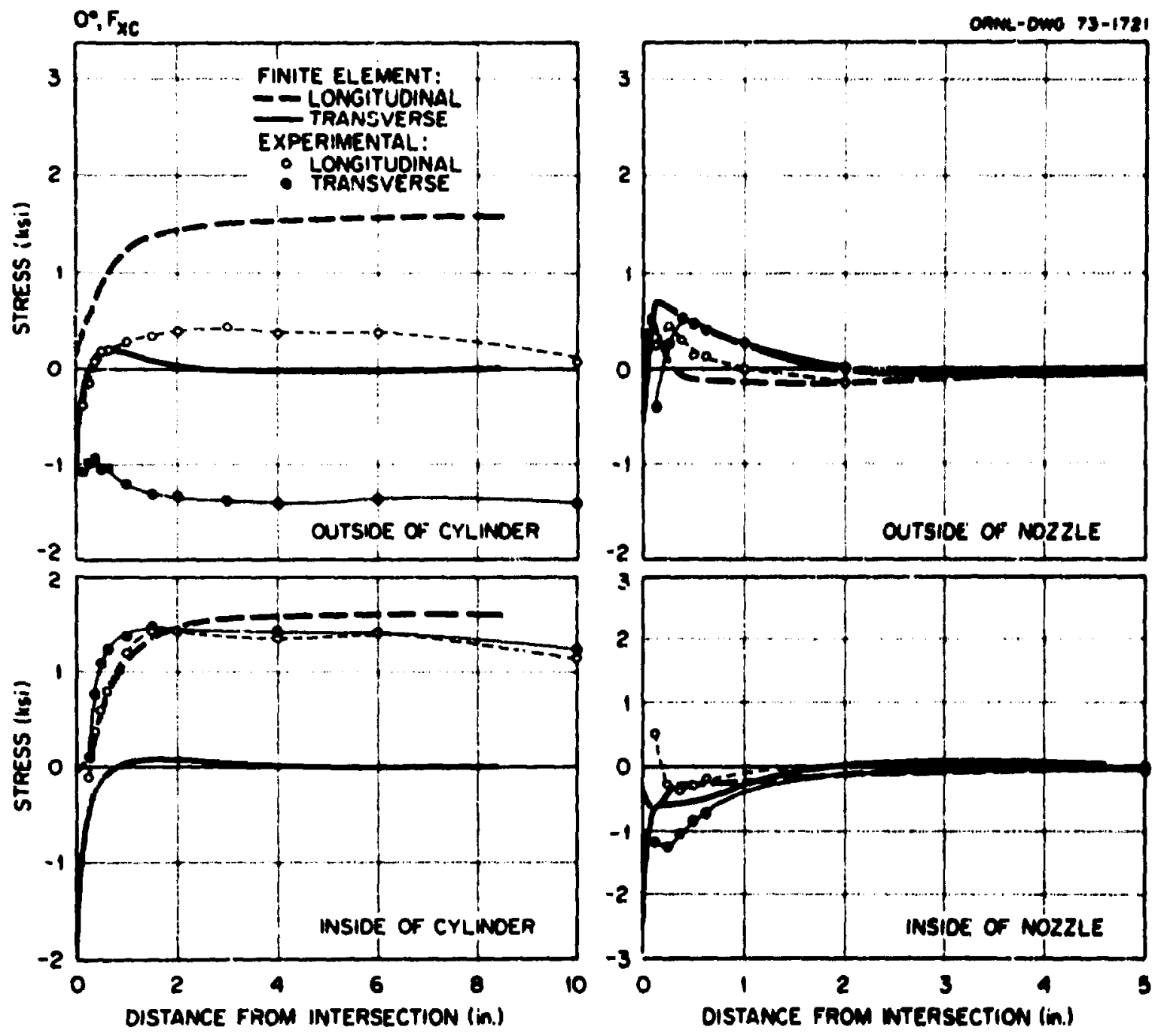

F8. 75. Meanured and prodicted strese distributions at $0^{\circ}$ for axial force, ' $X C$ ' on cylindor. 

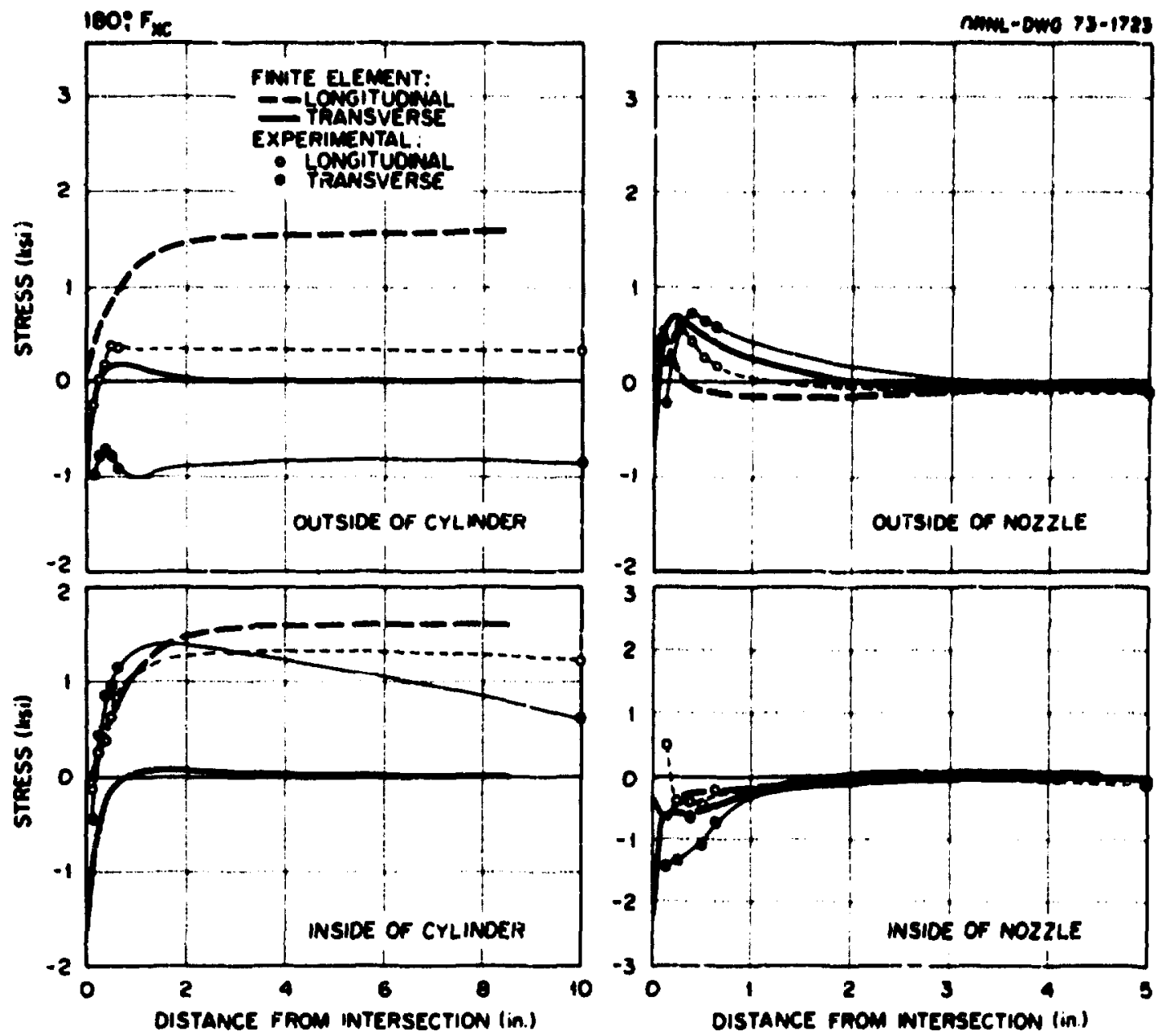

Fig. 76. Measured and prodicted strese dintributione at $180^{\circ}$ for axtal foree, $F_{X C}$, on cylinder. 

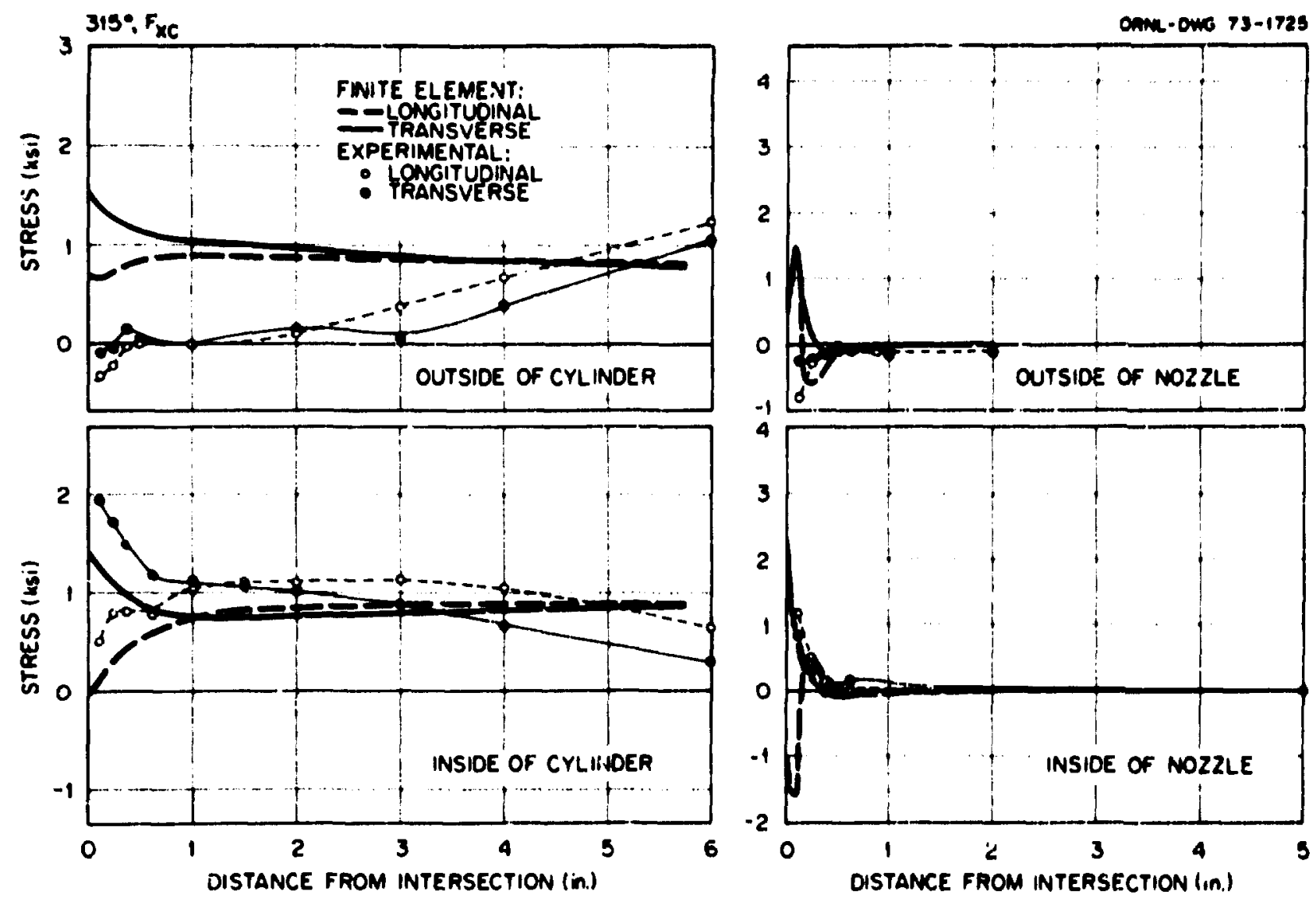

F18. 77. Messured and predicted stress distributions at $325^{\circ}$ for exial force, $F_{X C}$ on cylinder. 

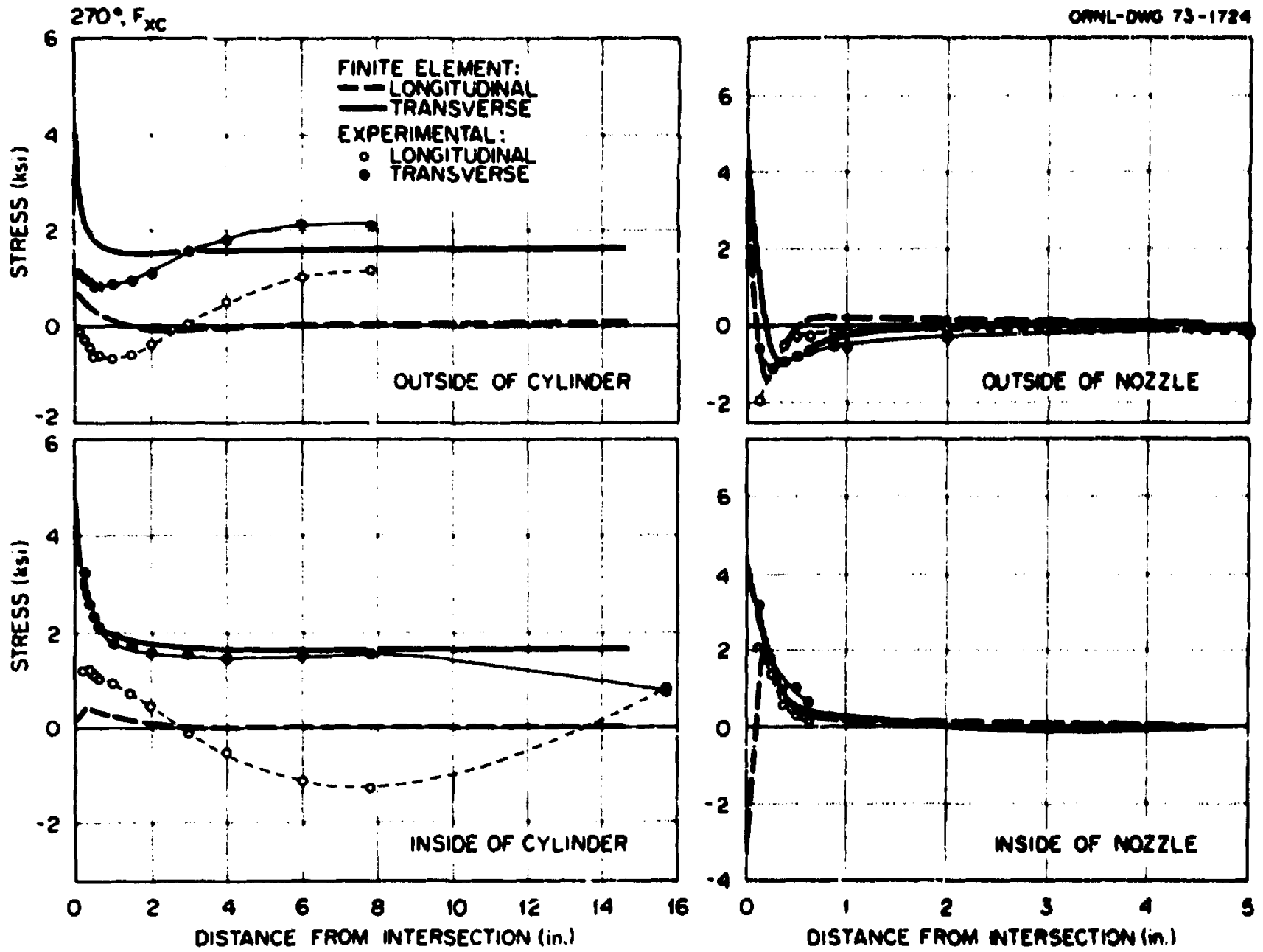

F18. 78. Moasured and prodicted strose distributions at $270^{\circ}$ for axial force, $F_{\mathrm{XC}}$, on cylinder. 

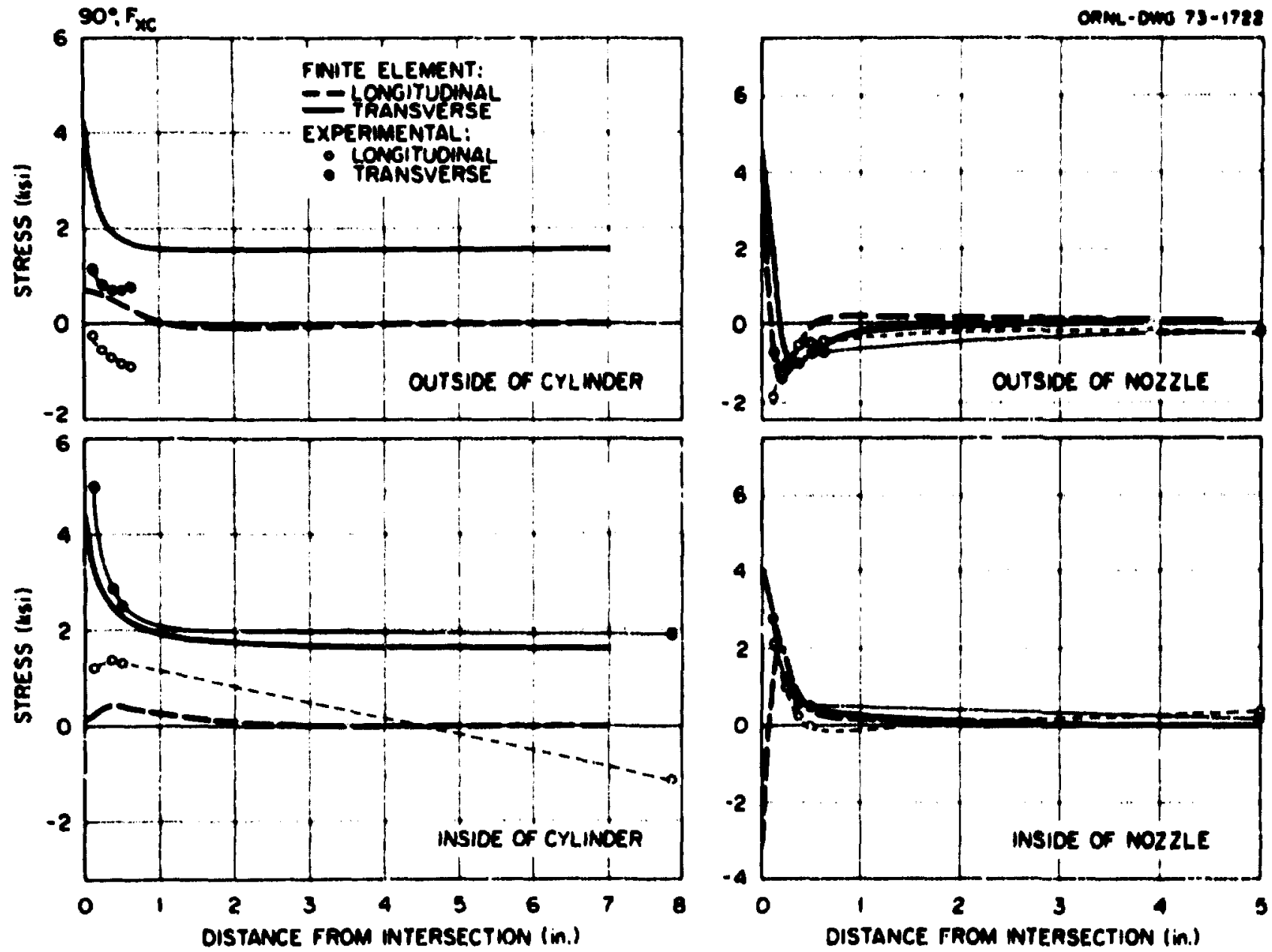

F18. 79. Measured and predicted strese diatributions at $90^{\circ}$ for axlal soree, $F_{X C}$, on cyllnder. 

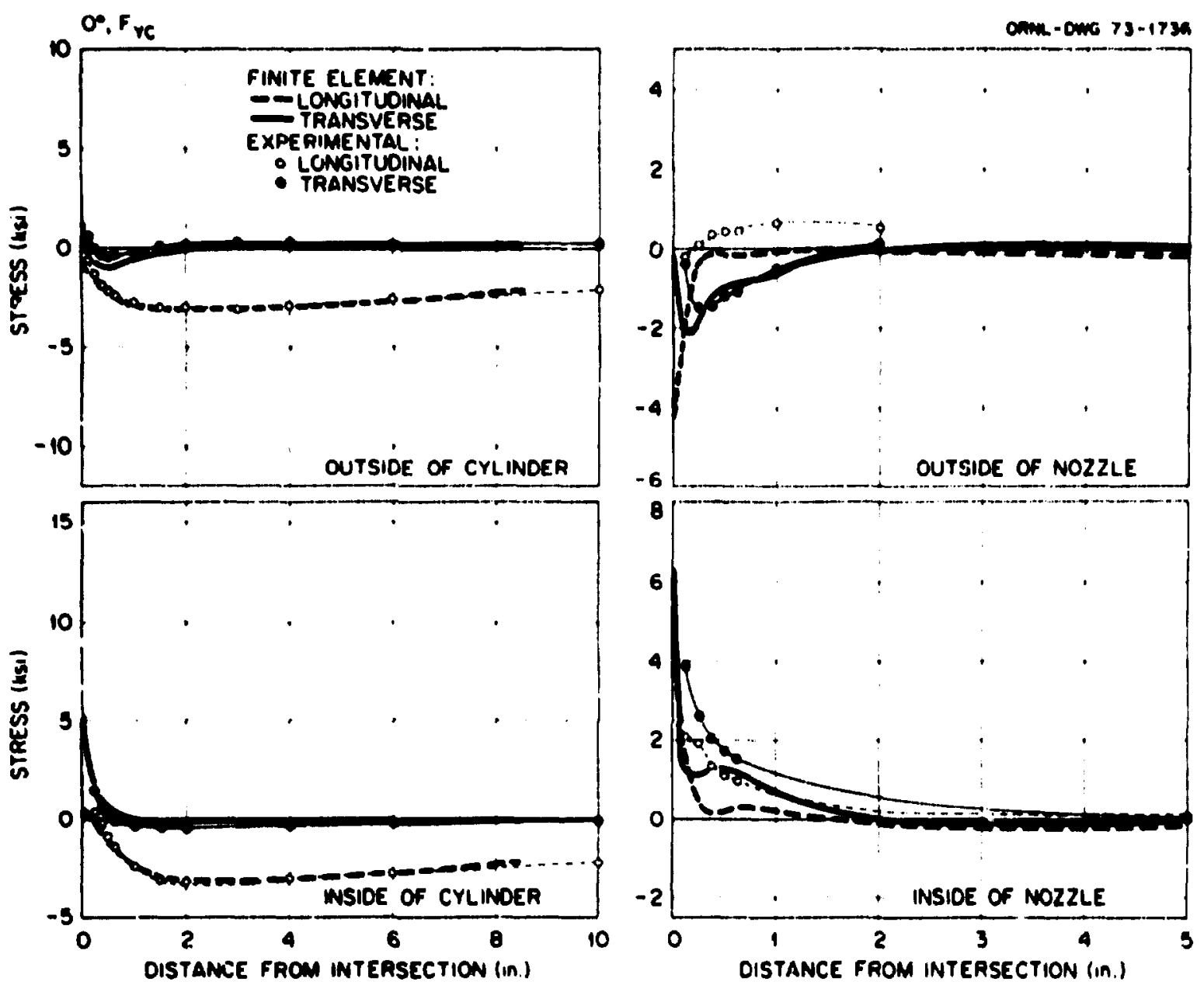

F1. 80. Masured and prodicted stress distritutions at $0^{\circ}$ for inplane force, $F_{Y C}$, on cylinder. 

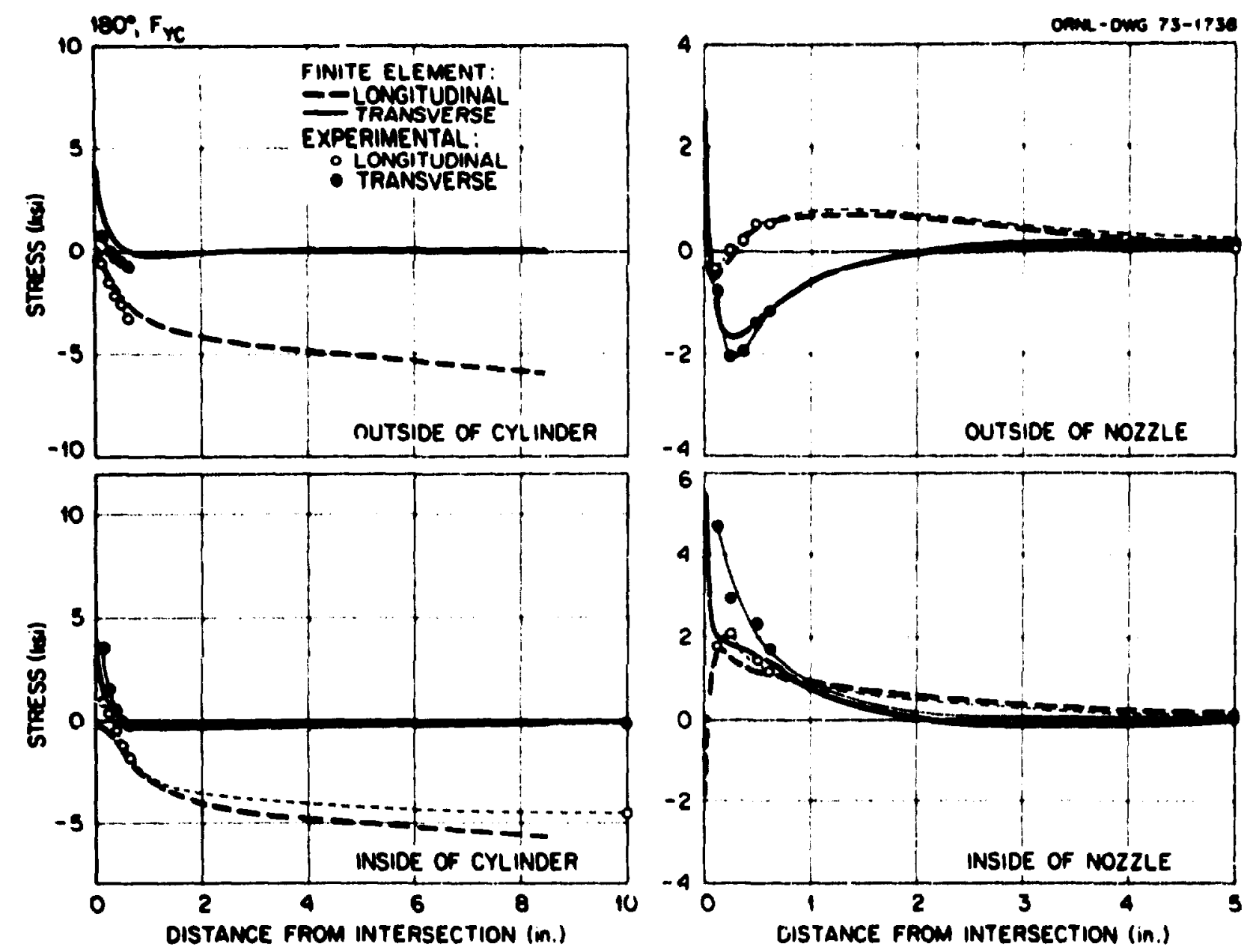

F18. 81. Measured and predicted atress diatributions at $180^{\circ}$ for In-plane seree, $F_{Y C}$ on cyllnder. 

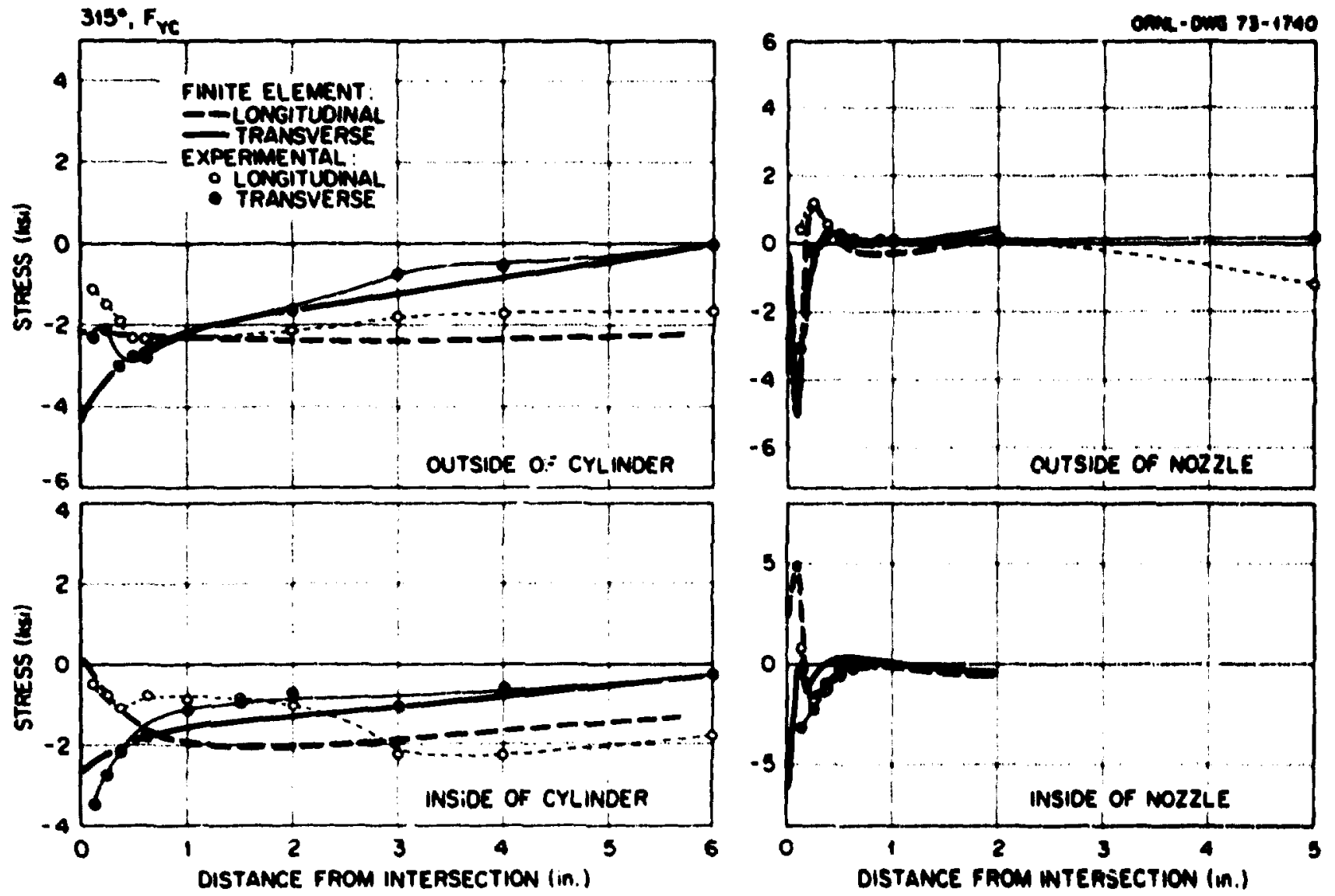

F18. 82. Measured and predicted stress distributions at $325^{\circ}$ for In-plane force, $F_{Y J}$, on cylinder. 

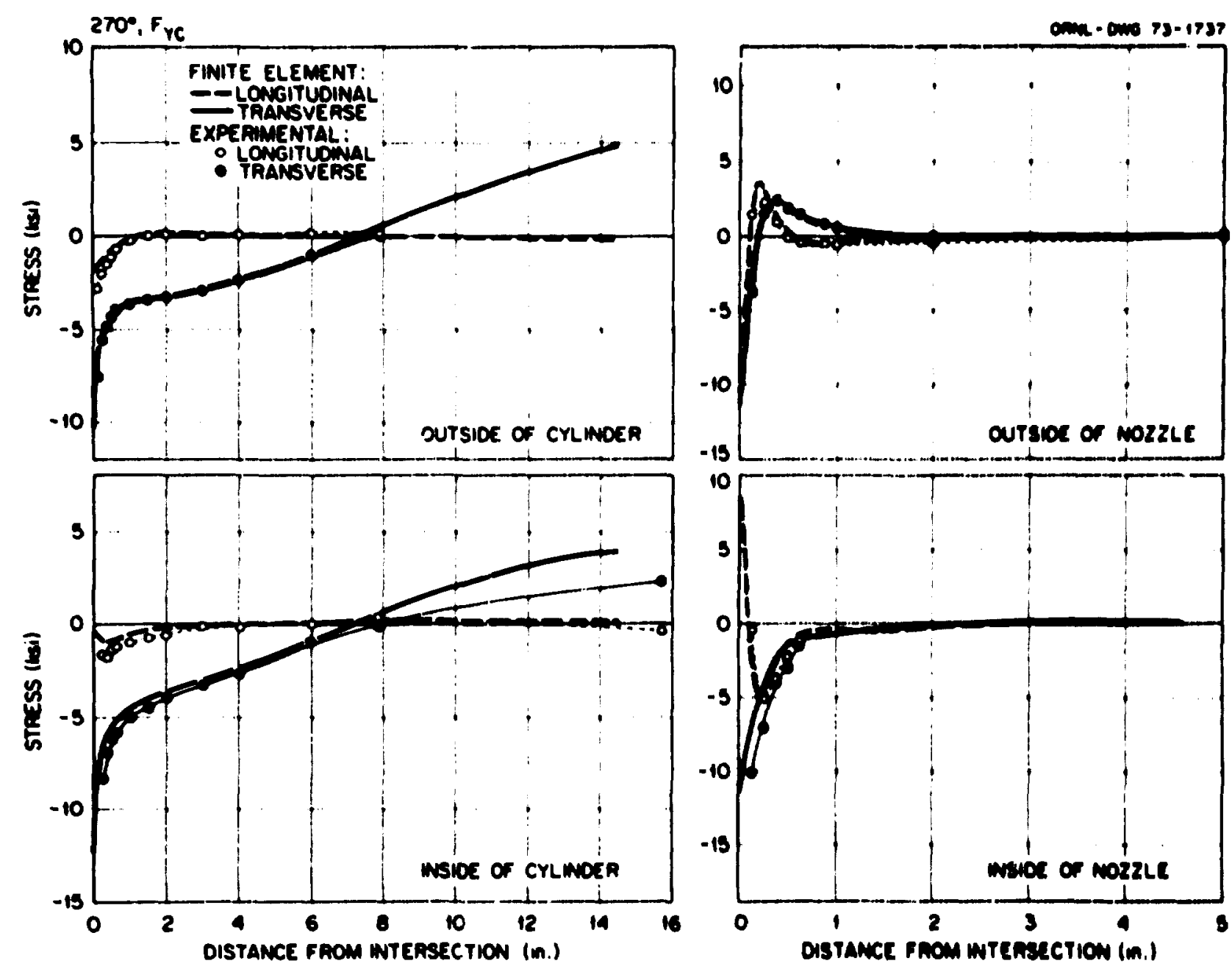

F18. 83. Masured and predioted atress distribution at $270^{\circ}$ sor In-plane fores, FYC on cylinder. 

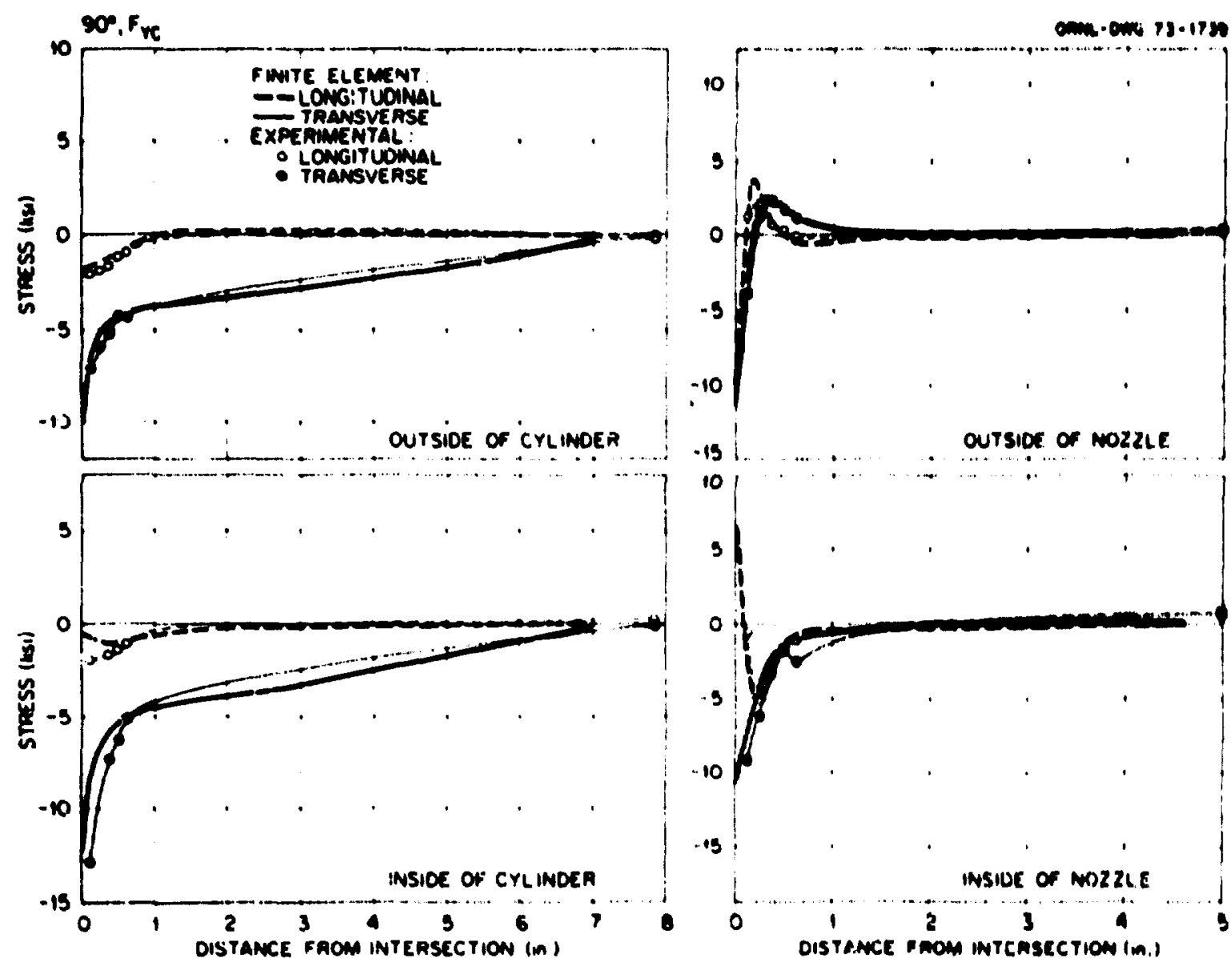

Fig. 84. Maseured and predicted atrane dintributiona at $90^{\circ}$ for inplane force, $\mathrm{T}_{\mathrm{YC}}$ ' on uylinder. 

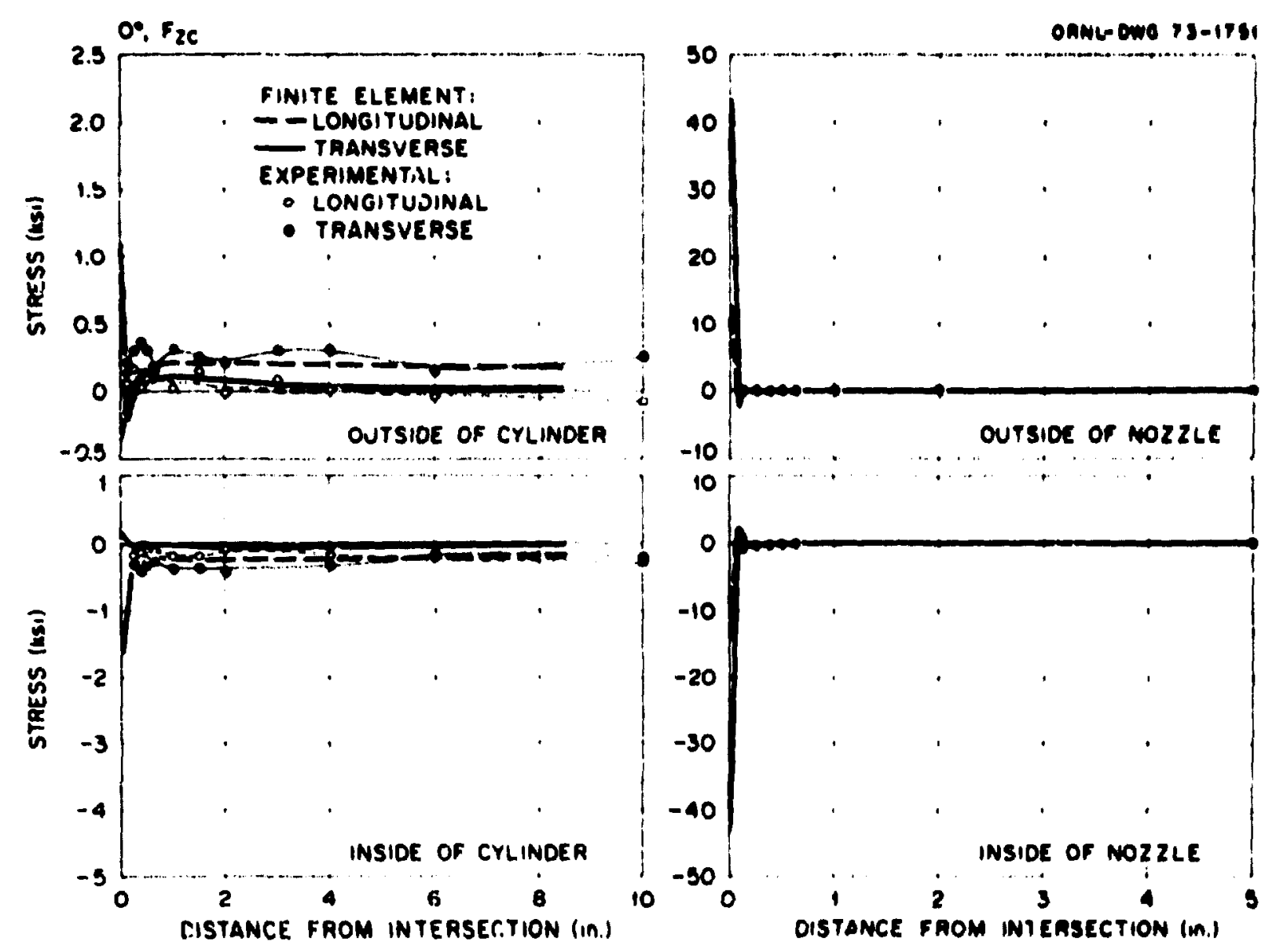

F18. 85. Measured and predicted stress diatributiona at $0^{\circ}$ for outor-plane roxee, $F_{\mathrm{ZC}}$, on cylinder. 


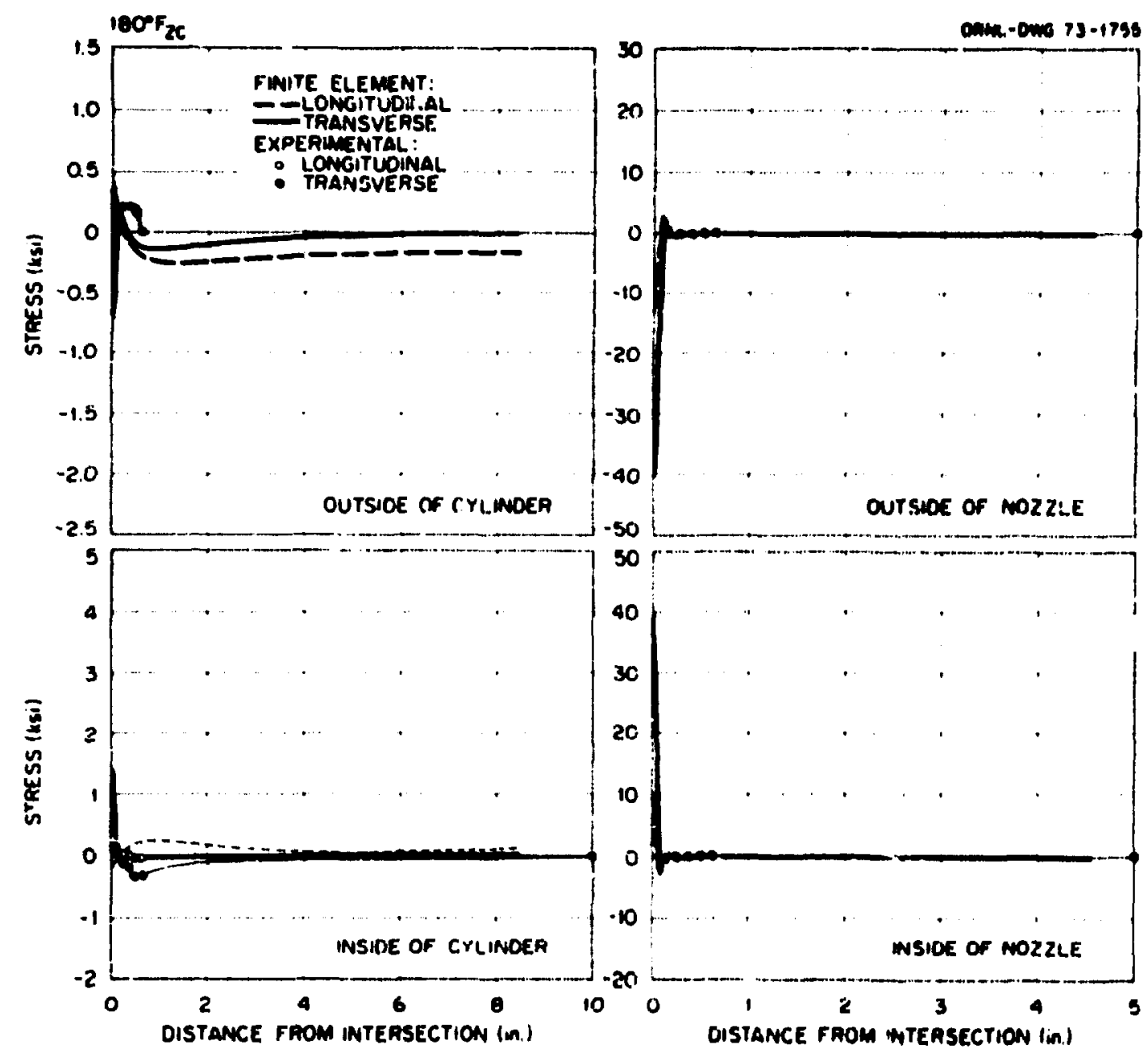

Mig. 86. Hossured and predicted stross dietributions at $180^{\circ}$ for out-or-plane rorce, $F_{\mathrm{ZC}}$, so cylinder. 

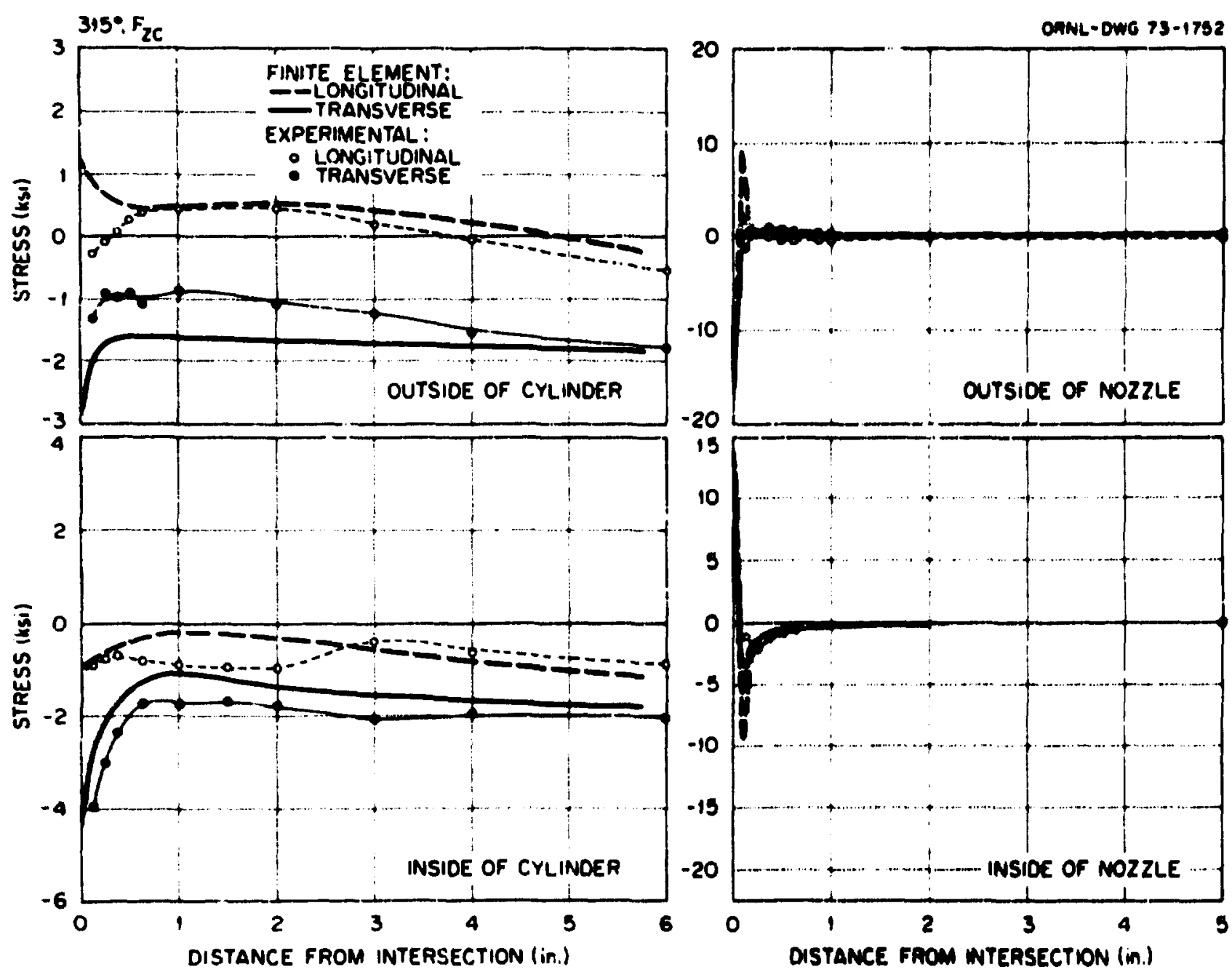

Flg. 87. Measured and predicted atrens distribution at $315^{\circ}$ for out-of-plare force, $F_{\mathrm{ZC}}$, on cylindor. 

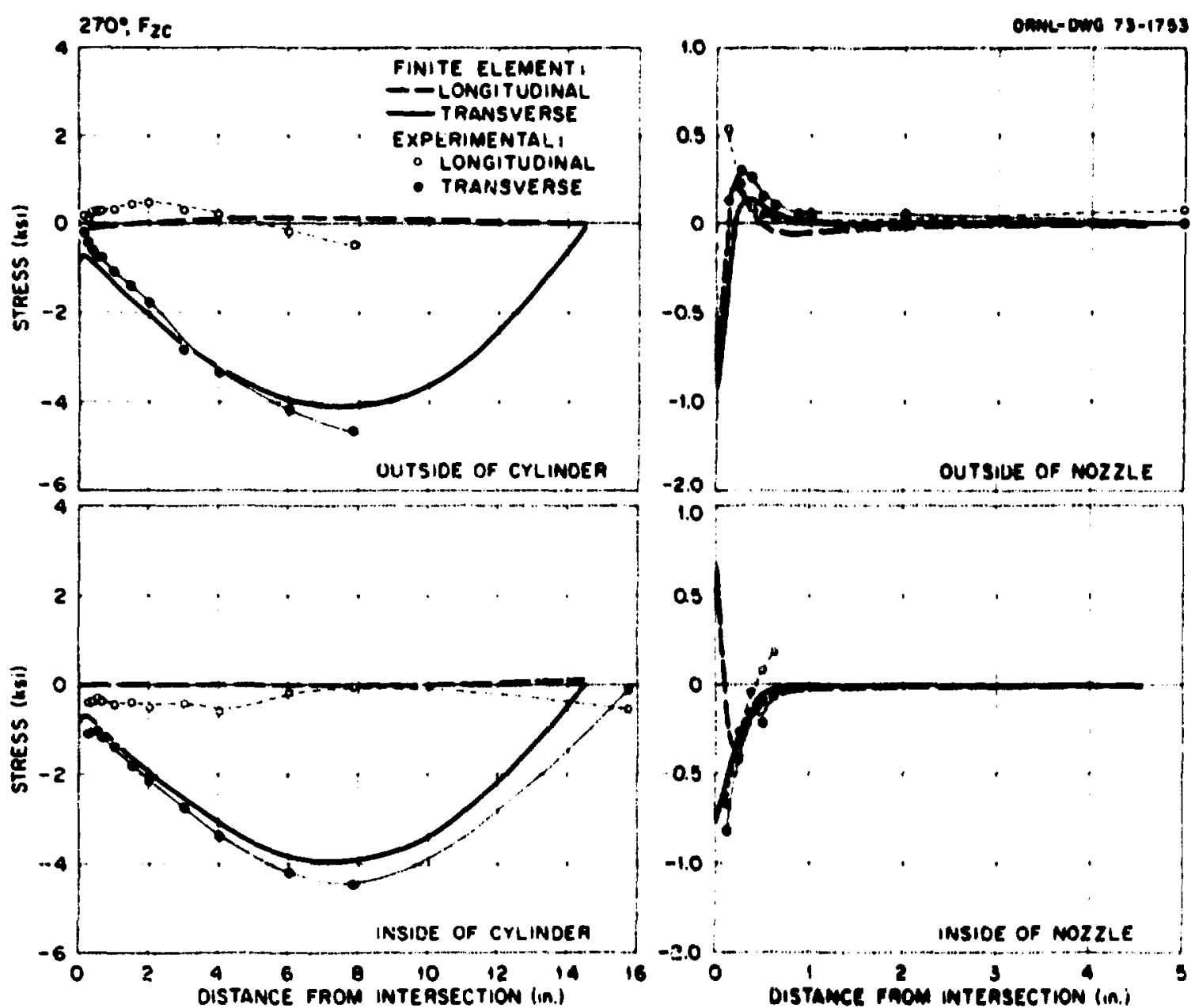

F1g. 88. Measured and predicted atrosn distributions at $270^{\circ}$ for out-or-plane force, $F_{\mathrm{zC}}$, on cylinder. 

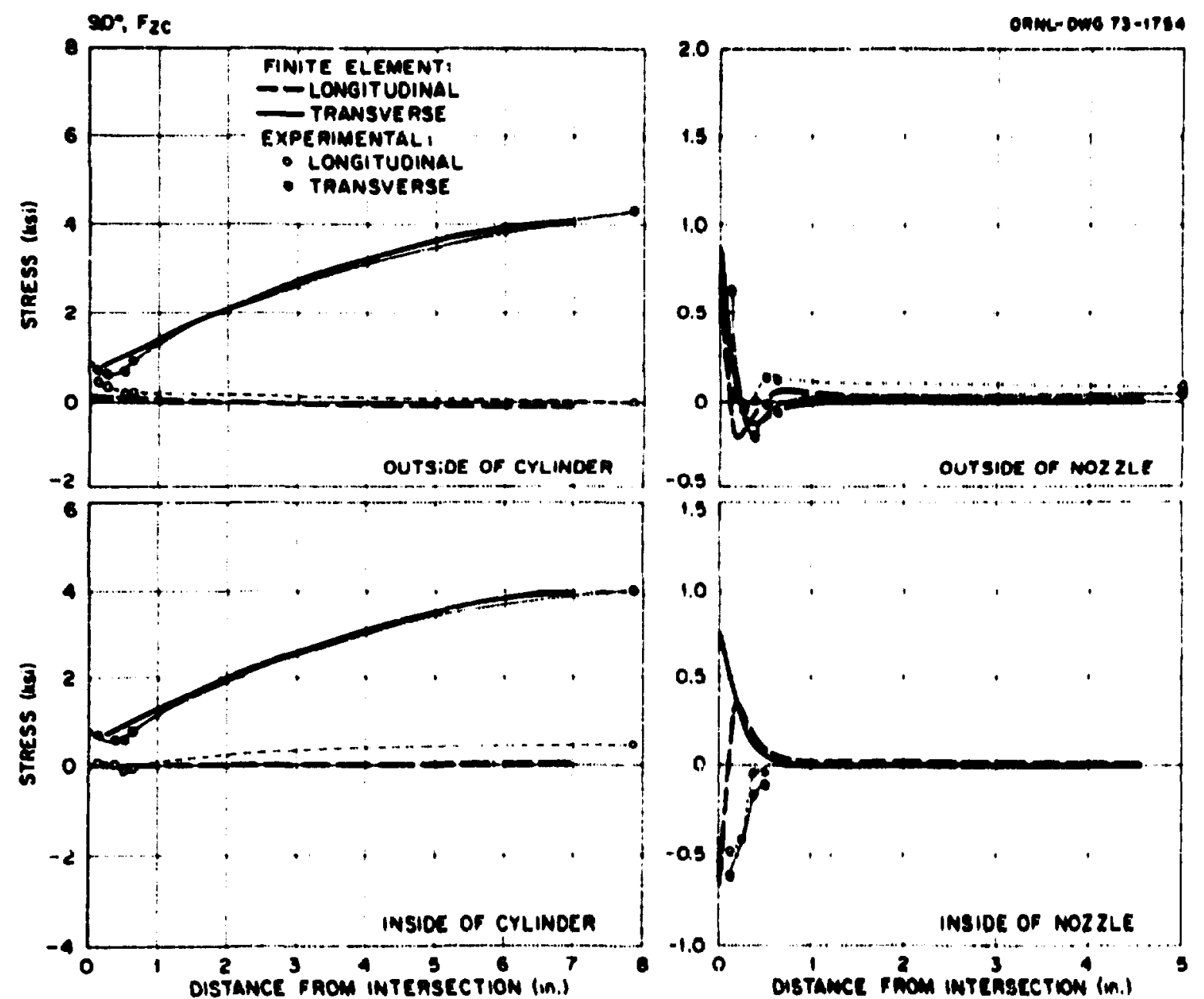

Fig. 89. Measured and predioted atrias diatributions at $90^{\circ}$ for outor-plane force, $F_{Z C}$, on cylinder. 


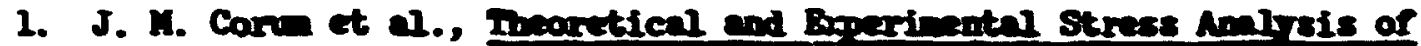

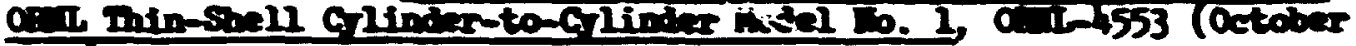
1972).

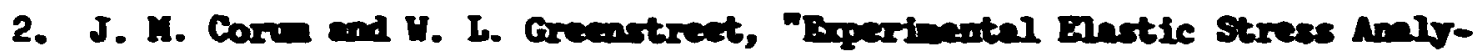

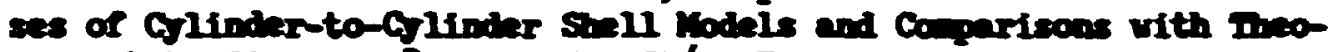

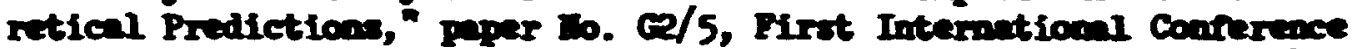
on Structural Nechanics in kenctor Rechnoloy, Berlin, Sept. 20-24, 1971.

3. R. C. Gulton, J. U. Bryson, and S. B. Bolt, mportical and Boper-

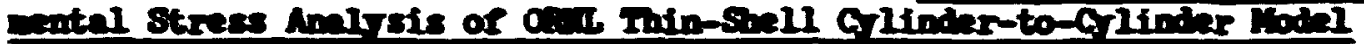
10. 3,0 in 5000 (to be poistished).

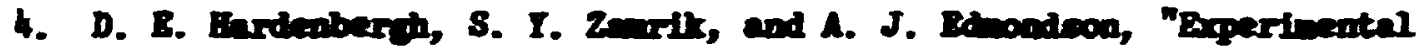
Investiation of Streases in Eossles in Gifindrienl Prescure Vessels," Weldin Beinch Counell Bulletin 89, Jul 1963.

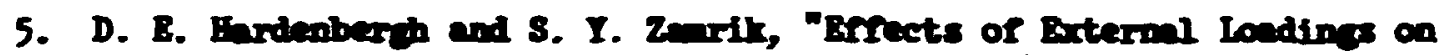

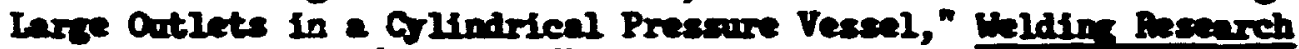
Counciz Bunctin 96, ins 1964.

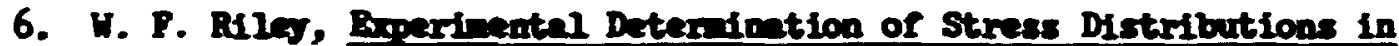

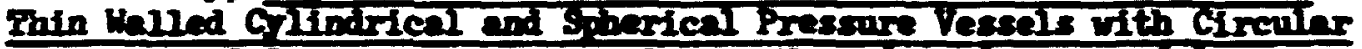

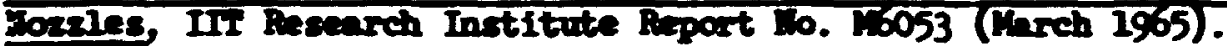

7. C. B. Tylor and I. C. Lind, "Photonlantic Stuty of the Strases near Openings in Pressure Vessels," Meldin Besearch Councll Bulletin 113. April 1966 .

8. H. H. Leven, "Photoelastic Deterndintion of Stresses in Refinforced Openings in Pressure Vessels," Veldin Research Council Bulletin 123 April 1966.

9. Ojars Greste, Pinite Blenent Anelyeis of Tubular $\mathrm{K}$ Jolnts, Report UCSESA 70-11, Univeraity of Callfornia, Berteley (June 1970).

10. H. Reidelbach, "The State of Stress at ths Perpendicular Intersection of Two Right Circular Tubes," Ingenieur-Archiv. 30(5), 293-316 (1961).

11. A. C. Eringen, A. K. Maghdi, and C. C. Thiel, "State of Stress in a Circular Cylindrical shell wth a Circular Hole," Welding Research Council Bulletin 102, Jnnuny 1965.

12. A. K. Nachal and A. C. Eringen, "Stress Distribution in a Circular Cylindrical shell with a Circular Cut-Out," Ingenieur-Archiv. 34(3). 161-72 (1965). 
13. A. C. Bringen and E. S. Srmbi, "Stress Distribution at no Dornaly Intersecting Shells," nucl. Struet. Bas. 2(3), 253-70 (1965).

14. A. c. Bringer et al., "stress Concentretions in no Dacilly Intersecting Gilinirical Shells Sobject to Intermal Presaure," Meldin hesearch Conneil. Bolletin 179, April 1969.

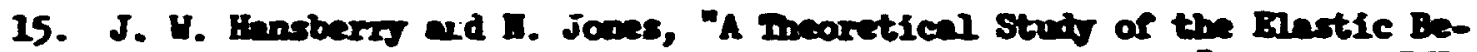
buior of no Hornils Intersectin Glindrical Shells," Inans. ASR, J. Bro. Ind. 221(3), 563-72 (1969).

16. R. F. Nave and A. C. Bringen, "Further Amelfois of no Foreally Intersectin Glindricel Siells sibjected to Intermal Pressure," Duel. Bon. Des. 12(3), 457-74 (1970).

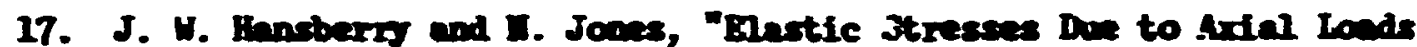

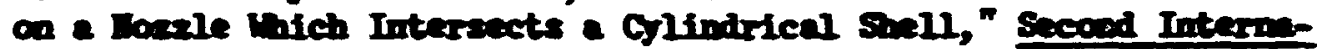
tionel conference on Presune vearel rechoolo th pet I, Desin and Anirsts, 129. 129, 0etobar 1973.

18. P. P. BLjleard, R. J. Dohnmann, and I. C. Uang, "Streseces in Junction of Doezle to Gifinder Pressure Veseal for Bqual Dinuter of Veasel and Forele," Ducl. Bres. Des. 5(3), 34t, 66 (1967).

19. K. C. Pan and R. B. Dechett, "Stress and DIsplacenent Analysis of a Shell Irtersection," Trens. ASiB, J. Bog. Ind. gab(3), 303-8 ( Hat 1970).

20. L. R. Herrman and D. K. Combell, "A Pinite-Blenent Aralysis for Thin Sbe11s," ATM J. 6(10), 1842-47 (1968).

21. 1. Prince and Y. R. Pushid, "Structurel Analrais of Suell Intersections," presented at Pirst International Conferepce on Pressure Vessels and Piping, Sept. 29-0ct. 2, :969, Delft, the letherlands.

22. C. P. Johrson, the Anerysis of Thin Shells by a Finite Bienent Procedure, Report 67-22, Departinent of Civil Engineering, Caiversity of Californte, Berteley (Septenber 1967).

23. C. P. Johnson and P. C. Snith, A Comouter Pro pen for the Analrais of Inin Shells, Report 69-5, Depertinent of Civil Engineering, Untversity of Califormia, Berteley (Augurt 1967).

24. Ojars Greste, A Corputer Prorram for the Analysis of Tubular $\mathrm{X}$ Joints, Report 69-19, Departent of Civil Brgineering, University of Callfornie, Berteley (Novenber 1969).

25. R. W. Clough and J. L. Tocher, "Pinite Blement Stifmess Matrices for the Analysis of Plate Bending," Proceedines of Conference on Vitrix

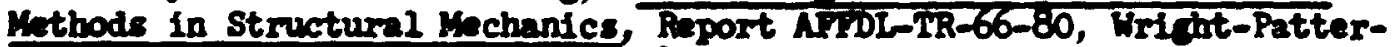
son Air Porce Base (November 1966). 
26. R. Bailey and R. Hicks, "Localised Loads Applied to a Spherical Pressure Vessel Imrough a Cylindrical Insert," J. Nech. Bag. Sci. 2(4), 302 (1964). 
Appendix

TABULATIOA GF EXPERDIEMIAL DATA

For the benefit of the reader who would like to use these experimental data to prepare camarisons with his om analysis techniques, the experimental data on wich the various plots in this report were based are given in Tables A.1 to A.13. For each loeding case, set of data is tabulated for each operable rosette. These data were obtained from the several sets of data taken in each case by the procedures described in Sect. 2.4 .

The rosette listings are gronged according to gage lines. For each rosette, the three strain readings are listed first, followed by the normil stress transverse (perpendiculer) to the gage line, the normal stress parallel to the gage line, the shear stress (referred to the gage line as a coordinate axis), and the maxial and ninial principal stresses. The strains are given in microinches per inch, and the stresses are in pounds per square inch.

The nomenclature used to identify and locate each rosette can be explained by consideriug the following semple designation:

$$
\text { I } 180 \text { E. }
$$

The letter I designates that the rosette is located on the inuer surface of nozzle or cylinder, an 0 in this position denotes an outside rosette. The muber 180 indicates that the rosette is located on the $180^{\circ}$ gage line (see $\mathrm{Yig}$. 3 for the gage line designetiors). The letter I indicates that the rosette is of the nozzle; a $C$ in tinis position designates a rosette on the cylinder; and $\mathrm{E}$ designates the location of the rosette along the gage line according to the following corrention:

\begin{tabular}{cc}
$\begin{array}{c}\text { Rosette } \\
\text { designation }\end{array}$ & $\begin{array}{c}\text { Distance from nozzle-cylinder } \\
\text { intersection (ste Fig. 3) } \\
(\text { In.) }\end{array}$ \\
\cline { 2 - 2 } A & $\approx 0$ \\
B & $1 / 8$ \\
C & $1 / 4$ \\
D & $3 / 8$ \\
E & $1 / 2$
\end{tabular}




\begin{tabular}{cc}
$\begin{array}{c}\text { Rosette } \\
\text { designation }\end{array}$ & $\begin{array}{c}\text { Distance fron nozzle-cylinder } \\
\text { intersection (see Fig. 3) } \\
\text { (in.) }\end{array}$ \\
\cline { 2 - 2 } F & $5 / 8$ \\
G & $7 / 8$ \\
H & 1 \\
J & $11 / 2$ \\
K & 2 \\
L & 3 \\
H & 4 \\
I & 5 \\
P & 6 \\
R & 7.85 \\
S & 10 \\
T & 15.7
\end{tabular}

In every case, the rosettes vere positioned on the gage ines so that the leg of the Y lay along the gage line and pointed awa from the nozzlecylinder junction. The convention used can be understood by referring to P18. 7. The leg of the $Y$ is designated as gage $I$ in the tabul: : ions, with gages 2 and 3 being numbered fra 1 in the counterclockrise direction.

Finally, in those cases where nonlinearity or drift was excessive or were an individual gage or circuit was otherwise obviously malfuncticaing, the rosette of which the gage was a part was not used in the final results plotted in this report for the specific loading under consideration. Nonetheless, these date are listed in the tabulations, but they are marked by an asterisk beside the rosette number. 
Table A.1. Intermal pressure

IMTERMAL PRESSORE (300 PSI)

\begin{tabular}{|c|c|c|c|c|c|c|c|c|}
\hline \multirow[b]{2}{*}{ OSTETE } & \multicolumn{3}{|c|}{ MICRC-STERTE } & \multicolumn{3}{|c|}{ STRESSES } & \multicolumn{2}{|c|}{ PRTE STRESSES } \\
\hline & GAGE1 & Gigez & GE 3 & and & 70 & SHETR & SIG. & TE \\
\hline r & $\begin{array}{r}-33 \\
45 \\
76 \\
105 \\
107 \\
88 \\
62 \\
-100 \\
50 \\
62 \\
57\end{array}$ & $\begin{array}{l}251 \\
286 \\
26 C \\
26 C \\
268 \\
186 \\
172 \\
165 \\
174 \\
179 \\
185\end{array}$ & $\begin{array}{l}360 \\
305 \\
260 \\
243 \\
210 \\
184 \\
184 \\
189 \\
177 \\
179 \\
165\end{array}$ & $\begin{array}{r}15658 \\
12950 \\
11344 \\
10945 \\
9056 \\
8028 \\
7743 \\
7767 \\
7655 \\
7799 \\
7704\end{array}$ & $\begin{array}{l}3696 \\
5245 \\
5693 \\
6433 \\
5937 \\
5056 \\
4184 \\
-672 \\
3800 \\
4202 \\
4030\end{array}$ & $\begin{array}{r}-127 \\
-254 \\
0 \\
222 \\
-32 \\
32 \\
-159 \\
-254 \\
-32 \\
0 \\
315\end{array}$ & $\begin{array}{r}15659 \\
12959 \\
11344 \\
10956 \\
9056 \\
8029 \\
7750 \\
7775 \\
7655 \\
7799 \\
7731\end{array}$ & $\begin{array}{l}3695 \\
5237 \\
5693 \\
6422 \\
5337 \\
5056 \\
4176 \\
-680 \\
3800 \\
4202 \\
4003\end{array}$ \\
\hline $\begin{array}{l}0 \\
1 \\
0 \\
5 \\
\end{array}$ & $\begin{array}{l}52 \\
45 \\
40 \\
19 \\
21 \\
21 \\
40 \\
57 \\
61 \\
54 \\
58 \\
59\end{array}$ & $\begin{array}{l}403 \\
296 \\
247 \\
228 \\
206 \\
161 \\
161 \\
156 \\
166 \\
168 \\
168 \\
159\end{array}$ & $\begin{array}{l}134 \\
310 \\
261 \\
223 \\
194 \\
175 \\
154 \\
159 \\
168 \\
161 \\
155 \\
168\end{array}$ & $\begin{array}{l}132 \\
111 \\
98 \\
87 \\
73 \\
68 \\
68 \\
72 \\
71 \\
71 \\
71\end{array}$ & $\begin{array}{l}78 \\
53 \\
45 \\
35 \\
38 \\
28 \\
32 \\
37 \\
48 \\
37 \\
37\end{array}$ & $\begin{array}{r}-110 \\
-190 \\
-189 \\
65 \\
158 \\
-189 \\
97 \\
-31 \\
-32 \\
94 \\
127 \\
-126\end{array}$ & $\begin{array}{r}18351 \\
13289 \\
11108 \\
9873 \\
8782 \\
7377 \\
6882 \\
6861 \\
7274 \\
7180 \\
7130 \\
7125\end{array}$ & $\begin{array}{l}7 \\
5 \\
4 \\
3 \\
3 \\
2 \\
3 \\
3 \\
4 \\
3 \\
3\end{array}$ \\
\hline 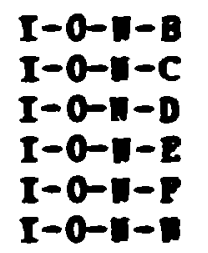 & $\begin{array}{r}-352 \\
158 \\
184 \\
117 \\
69 \\
22\end{array}$ & $\begin{array}{l}398 \\
304 \\
184 \\
105 \\
77 \\
72\end{array}$ & $\begin{array}{l}112 \\
297 \\
201 \\
120 \\
91 \\
77\end{array}$ & $\begin{array}{r}18176 \\
13037 \\
8271 \\
4819 \\
3508 \\
3240\end{array}$ & $\begin{array}{r}-5 \\
8 \\
80 \\
4 \\
3 \\
10\end{array}$ & $\begin{array}{r}-191 \\
96 \\
-223 \\
-191 \\
-191 \\
-64\end{array}$ & $\begin{array}{r}18178 \\
13039 \\
8400 \\
5098 \\
3679 \\
3242\end{array}$ & $\begin{array}{r}-5110 \\
8651 \\
788 \\
468 \\
309 \\
1610\end{array}$ \\
\hline 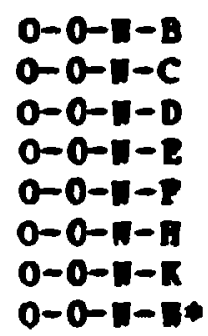 & $\begin{array}{r}-67 \\
-67 \\
19 \\
69 \\
78 \\
64 \\
35\end{array}$ & $\begin{array}{r}316 \\
68 \\
14 \\
19 \\
35 \\
59 \\
71 \\
59\end{array}$ & $\begin{array}{r}287 \\
64 \\
12 \\
24 \\
42 \\
62 \\
71 \\
1616\end{array}$ & $\begin{array}{r}13305 \\
2980 \\
545 \\
857 \\
1626 \\
2582 \\
3083 \\
36795\end{array}$ & $\begin{array}{r}1995 \\
-1105 \\
726 \\
2314 \\
2829 \\
2690 \\
1984 \\
11675\end{array}$ & $\begin{array}{r}379 \\
53 \\
30 \\
-64 \\
-94 \\
-31 \\
-1 \\
-20749\end{array}$ & $\begin{array}{r}13318 \\
2981 \\
731 \\
2317 \\
2836 \\
2699 \\
3083 \\
48489\end{array}$ & $\begin{array}{r}19 \\
-11 \\
5 \\
8 \\
16 \\
25 \\
19\end{array}$ \\
\hline
\end{tabular}


Table A.I (continised)

InTEREAL FRESSORE (300 PSI)

\begin{tabular}{|c|c|c|c|c|c|c|c|c|}
\hline \multirow[b]{2}{*}{ DOSETTE } & \multicolumn{3}{|c|}{ mICRO-STEATE } & \multicolumn{3}{|c|}{ STRESSES } & \multicolumn{2}{|c|}{ PRI STRESSES } \\
\hline & GAGE 1 & $16 E 2$ & E 3 & an us & LOIG & Ge AR & STGn $x$ & IGE \\
\hline $\begin{array}{l}I-90 C-E \\
I-90 C-C \\
I-90 C-D \\
I-90 C-E \\
I-90 C-I \\
I-90 C-Z\end{array}$ & $\begin{array}{r}-31 \\
5 \\
55 \\
91 \\
105 \\
199\end{array}$ & $\begin{array}{l}14 \\
68 \\
57 \\
60 \\
36 \\
77\end{array}$ & $\begin{array}{r}7 \\
0 \\
53 \\
57 \\
57 \\
84\end{array}$ & $\begin{array}{r}508 \\
1047 \\
2359 \\
2478 \\
1948 \\
3306\end{array}$ & $\begin{array}{r}-781 \\
458 \\
2360 \\
3472 \\
3744 \\
6953\end{array}$ & $\begin{array}{r}96 \\
638 \\
64 \\
32 \\
-280 \\
-96\end{array}$ & $\begin{array}{r}515 \\
1455 \\
2423 \\
3473 \\
3787 \\
6955\end{array}$ & $\begin{array}{r}-788 \\
50 \\
2296 \\
2477 \\
1905 \\
3304\end{array}$ \\
\hline $\begin{array}{l}0-90 C-B \\
0-90 C-C \\
0-90 C-D \\
0-90 C-E \\
0-90 C-P \\
0-90 C-B\end{array}$ & $\begin{array}{r}35 \\
78 \\
112 \\
135 \\
157 \\
173\end{array}$ & $\begin{array}{r}187 \\
218 \\
221 \\
190 \\
183 \\
83\end{array}$ & $\begin{array}{r}213 \\
235 \\
214 \\
197 \\
183 \\
93\end{array}$ & $\begin{array}{l}8757 \\
9879 \\
9425 \\
8355 \\
7862 \\
3670\end{array}$ & $\begin{array}{l}3686 \\
5314 \\
6175 \\
6566 \\
7059 \\
6300\end{array}$ & $\begin{array}{r}-349 \\
-221 \\
95 \\
-95 \\
0 \\
-127\end{array}$ & $\begin{array}{l}8781 \\
9889 \\
9427 \\
8360 \\
7862 \\
6306\end{array}$ & $\begin{array}{l}3662 \\
5303 \\
6172 \\
6561 \\
7059 \\
3664\end{array}$ \\
\hline $\begin{array}{l}I-90 \pi-B \\
I-90 \pi-C \\
I-90 \pi-D \\
I-90 \pi-Z \\
I-90 \pi-P \\
I-90 \pi-I\end{array}$ & $\begin{array}{r}-291 \\
-5 \\
33 \\
7 \\
184 \\
148\end{array}$ & $\begin{array}{r}95 \\
114 \\
76 \\
55 \\
172 \\
456\end{array}$ & $\begin{array}{r}38 \\
86 \\
81 \\
57 \\
62 \\
225\end{array}$ & $\begin{array}{r}3257 \\
4409 \\
3421 \\
2454 \\
4936 \\
14798\end{array}$ & $\begin{array}{r}-7760 \\
1180 \\
2023 \\
946 \\
6991 \\
8883\end{array}$ & $\begin{array}{r}763 \\
381 \\
-65 \\
-32 \\
1462 \\
3087\end{array}$ & $\begin{array}{r}3310 \\
4453 \\
3424 \\
2455 \\
7750 \\
16115\end{array}$ & $\begin{array}{r}-7812 \\
1135 \\
2020 \\
945 \\
1176 \\
7565\end{array}$ \\
\hline $\begin{array}{l}0-901-B \\
0-901-C \\
0-901--D \\
0-901-E \\
0-901-P \\
0-904-B\end{array}$ & $\begin{array}{r}-47 \\
-121 \\
-81 \\
-12 \\
-7 \\
38\end{array}$ & $\begin{array}{r}221 \\
123 \\
86 \\
83 \\
52 \\
62\end{array}$ & $\begin{array}{r}228 \\
119 \\
76 \\
71 \\
71 \\
62\end{array}$ & $\begin{array}{l}9912 \\
5454 \\
3636 \\
3403 \\
2720 \\
2670\end{array}$ & $\begin{array}{r}1550 \\
-1996 \\
-1330 \\
665 \\
602 \\
1940\end{array}$ & $\begin{array}{r}-95 \\
63 \\
127 \\
158 \\
-253 \\
0\end{array}$ & $\begin{array}{l}9913 \\
5455 \\
3639 \\
3412 \\
2750 \\
2670\end{array}$ & $\begin{array}{r}1549 \\
-1996 \\
-1334 \\
656 \\
573 \\
1940\end{array}$ \\
\hline
\end{tabular}


Table A.1 (continued)

IUTERWAL PRESSORE (300 RST)

GICRO-STQRTE

PRIn STRESSES

$-\infty-\infty$

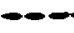

LOSETTE GIGEI GIGE2 GLGE3

TRAIS

LOI6

SaELR

SIGax

SIGni

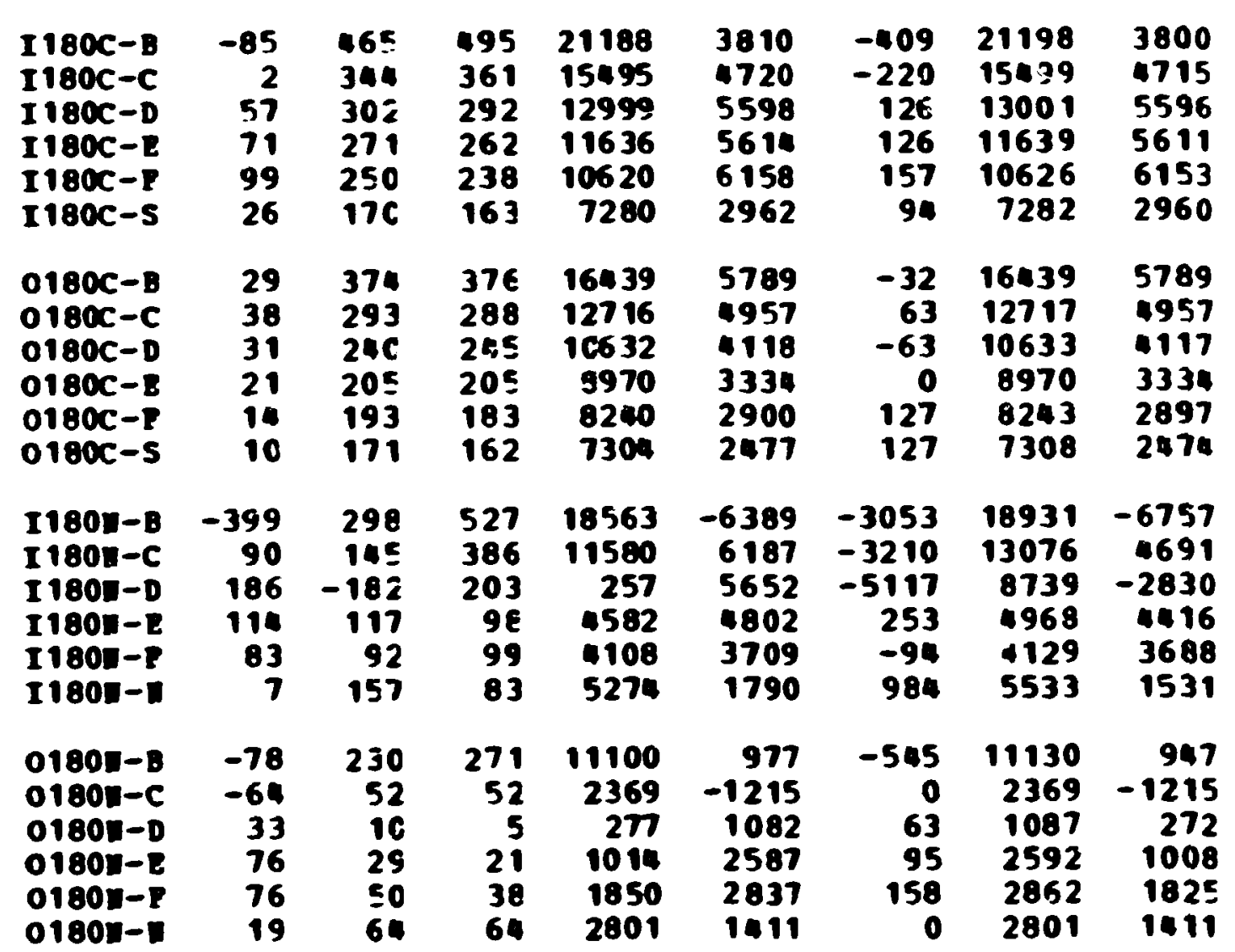


Table A.I (continued)

IETERALL PRESSURE (300 PSI)

GICRO-SI FRIA

ROSETTE GAGEI GAGE2 GAGEJ

I270-

1270-

I270C-E

I270C-P

I270c-n

I $27 \mathrm{CC}-\mathrm{J}$

I270C-R*

I270C-I

I270C-6

$1270 \mathrm{C}-\mathrm{P}$

I270C-I

I270C-T

$0270 \mathrm{C}-\mathrm{B}$

$0270 \mathrm{C}-\mathrm{C}$

0270C-D

0270C-E

$0270 C-P$

$0270 \mathrm{C}-\mathrm{B}$

$0270 \mathrm{C}-\mathrm{J}$

0270C-R

0270c-L

0270c-a

0270C-P

0270c-R

0270C-T*

4

59

97

133

176

207

203

212

217

201

197

153

79

105

133

147

157

169

190

188

202

190

190

195

183

CIGE2 6

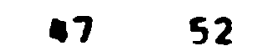

54

52

59

64

71

83

148

107

$10 \mathrm{C}$

95

105

15

64

64

61

93

95

90

93

95

89

55

247

228

238

219

205

216

212

195

190

176

15s

152

121

117

$100 \quad 100$

10C 88

96

81

83

90

86

90

162

I270s-B - 30 s

I270I-C -5

270-0

I2701-E

I270س-P

36

17

$-7$

0270n-

0270n-c

0270n-

02701-

O270N-F

0270N-6

0270س-a

0270D-R

0270n-1
60

103

105

112

4

237

111

71

59

64

62

57

43

EE
36

98

81

$4 \varepsilon$

41

206

114

81

67

67

62

57

48
STRESSES

PRII STRESSES

Tanus

-

2177

2483

2597

2664

2719

3636

5111

4097

3987

3913

4051

1473

10578

9557

9312

8721

7875

6660

5017

4183

3906

3608

3556

3655

2047

2433

4411

4052

3496

1849

9787

5082

3448

2831

2914

2747

2535

1984

2436
LONG

-

784

2521

3700

4794

6097

7304

7609

7530

7694

7192

7115

5042

5529

6036

6789

7039

7071

7063

7212

6890

7235

6793

6777

6950

6110

$-8435$

1180

2290

1550

333

1648

$-2178$

-1789
-792

$-196$

39

47

667

1302
SEEAR

SIGnI

- --

$\begin{array}{lll}-64 & 2180 \quad 781\end{array}$

$-9726012403$

$\begin{array}{lll}-64 & 3704 & 2593\end{array}$

$04794 \quad 2664$

$\begin{array}{lll}128 & 6102 & 2715\end{array}$

$\begin{array}{lll}-128 & 7308 & 3631\end{array}$

$\begin{array}{lll}698 & 7791 & 4929\end{array}$

$2187603 \quad 084$

$947696 \quad 3985$

$\begin{array}{lll}-29 & 7193 & 3912\end{array}$

$\begin{array}{lll}222 & 7131 & 4035\end{array}$

$\begin{array}{lll}-479 & 5105 \quad 1410\end{array}$

12? 10581 5526

$158 \quad 9654 \quad 6029$

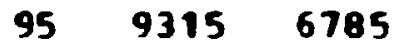

190

190

95

63

158

158

95

$-127$

$-63$

8743

7918

7084

721.

6890

7243

6795

6782

6951

$1363 \quad 6525$

7018

7028

6639

5015

4183

3899

3605

3551

3654

1632

$318 \quad 244$

64 4412

$318 \quad 4107$

859

3820

1850

$\begin{array}{lll}410 \quad 9807 & 1628\end{array}$

$\begin{array}{lll}-31 & 5082-2178\end{array}$

$-127$

$3451-1752$ 
Table A.I (continued)

I TrEREAL PRESSORE (300 PSI)

aICRO-STEAID

-

MOSETTE GAGEI GAGE 2 GAGE 3

$$
-
$$

\begin{tabular}{|c|c|c|c|c|c|c|c|c|}
\hline $\begin{array}{l}315 C-B \\
315 C-C \\
315 C-D \\
315 C-F \\
315 C-A \\
315 C-J \\
315 C-R \\
315 C-L \\
315 C-E\end{array}$ & $\begin{array}{r}-74 \\
-12 \\
55 \\
174 \\
179 \\
184 \\
174 \\
132 \\
108 \\
124\end{array}$ & $\begin{array}{r}167 \\
100 \\
75 \\
135 \\
134 \\
143 \\
143 \\
72 \\
83 \\
65\end{array}$ & $\begin{array}{l}315 \\
325 \\
292 \\
185 \\
210 \\
198 \\
193 \\
191 \\
203 \\
194\end{array}$ & $\begin{array}{r}16685 \\
9357 \\
7790 \\
7000 \\
7362 \\
7304 \\
7210 \\
5640 \\
6167 \\
5541\end{array}$ & $\begin{array}{l}984 \\
2449 \\
3987 \\
7331 \\
7583 \\
7709 \\
7394 \\
5639 \\
5079 \\
5394\end{array}$ & $\begin{array}{r}-1973 \\
-2992 \\
-2751 \\
-668 \\
-1018 \\
-732 \\
-668 \\
-1592 \\
-1607 \\
-1720\end{array}$ & $\begin{array}{r}11071 \\
10472 \\
9233 \\
7854 \\
8497 \\
8266 \\
7977 \\
7231 \\
7320 \\
7190\end{array}$ & $\begin{array}{r}598 \\
1334 \\
2544 \\
6477 \\
6448 \\
6747 \\
6627 \\
4048 \\
3927 \\
3746\end{array}$ \\
\hline $\begin{array}{l}-\mathbf{B} \\
-\mathbf{C} \\
\mathbf{D} \\
\mathbf{E} \\
\mathbf{P} \\
-\mathbf{B} \\
\mathbf{K} \\
-\mathbf{L} \\
-\mathbf{E} \\
-\mathbf{P}\end{array}$ & $\begin{array}{r}64 \\
78 \\
78 \\
59 \\
83 \\
88 \\
109 \\
116 \\
126 \\
126\end{array}$ & $\begin{array}{l}311 \\
297 \\
320 \\
301 \\
278 \\
245 \\
206 \\
197 \\
199 \\
187\end{array}$ & $\begin{array}{r}171 \\
102 \\
123 \\
102 \\
70 \\
57 \\
50 \\
57 \\
62 \\
55\end{array}$ & $\begin{array}{r}10517 \\
9563 \\
9667 \\
8901 \\
7628 \\
6632 \\
5513 \\
5453 \\
5599 \\
5182\end{array}$ & $\begin{array}{l}5078 \\
5219 \\
5250 \\
4421 \\
1780 \\
4624 \\
4929 \\
5125 \\
5453 \\
5328\end{array}$ & $\begin{array}{l}1866 \\
2055 \\
2625 \\
2656 \\
2719 \\
2561 \\
2087 \\
1866 \\
1834 \\
1771\end{array}$ & $\begin{array}{r}11095 \\
10381 \\
10889 \\
10054 \\
9274 \\
8379 \\
7328 \\
7162 \\
7362 \\
7027\end{array}$ & $\begin{array}{l}4499 \\
4400 \\
4028 \\
3168 \\
3135 \\
2877 \\
3114 \\
3416 \\
3691 \\
3483\end{array}$ \\
\hline$\left[\begin{array}{l}3 \\
{[3} \\
{[3}\end{array}\right.$ & $\begin{array}{r}-277 \\
69 \\
103 \\
48 \\
19 \\
24\end{array}$ & $\begin{array}{r}194 \\
201 \\
138 \\
62 \\
41 \\
35\end{array}$ & $\begin{array}{l}213 \\
225 \\
140 \\
72 \\
72 \\
87\end{array}$ & $\begin{array}{l}9240 \\
9280 \\
5932 \\
2891 \\
2449 \\
2569\end{array}$ & $\begin{array}{r}-5551 \\
4865 \\
4865 \\
2303 \\
1309 \\
1508\end{array}$ & $\begin{array}{l}-255 \\
-319 \\
-159 \\
-127 \\
-114 \\
-691\end{array}$ & $\begin{array}{l}9245 \\
9303 \\
5955 \\
2917 \\
2584 \\
2992\end{array}$ & $\begin{array}{r}-5556 \\
4842 \\
4842 \\
2276 \\
1174 \\
1186\end{array}$ \\
\hline 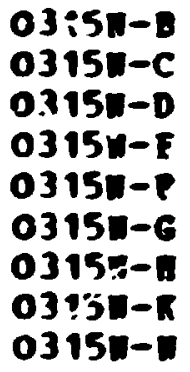 & $\begin{array}{r}-33 \\
-112 \\
-52 \\
-3 \\
18 \\
21 \\
18 \\
16 \\
-43\end{array}$ & $\begin{array}{r}325 \\
108 \\
23 \\
5 \\
19 \\
32 \\
35 \\
49 \\
61\end{array}$ & $\begin{array}{l}211 \\
97 \\
58 \\
63 \\
73 \\
75 \\
73 \\
61 \\
58\end{array}$ & $\begin{array}{r}11823 \\
4556 \\
1854 \\
1599 \\
1982 \\
2338 \\
2345 \\
2395 \\
2556\end{array}$ & $\begin{array}{r}2551 \\
-1979 \\
-1001 \\
404 \\
1148 \\
1326 \\
1259 \\
1204 \\
-478\end{array}$ & $\begin{array}{r}1518 \\
95 \\
-467 \\
-717 \\
-721 \\
-565 \\
-500 \\
-155 \\
31\end{array}$ & $\begin{array}{r}12065 \\
4557 \\
1929 \\
1935 \\
2397 \\
2590 \\
2541 \\
2415 \\
2666\end{array}$ & $\begin{array}{r}2308 \\
-1981 \\
-1075 \\
68 \\
732 \\
1072 \\
1063 \\
1180 \\
-479\end{array}$ \\
\hline
\end{tabular}


Table A.2. 'Jut-of-plane moment, $M_{X N}$, on nozzle

\begin{tabular}{|c|c|c|c|c|c|c|c|c|}
\hline \multirow[b]{2}{*}{ OSETTE } & \multicolumn{3}{|c|}{ MICRO-STRAIN } & \multicolumn{3}{|c|}{ STRESSES } & \multicolumn{2}{|c|}{ PRIN STRESSES } \\
\hline & GAGE1 & GAGE2 & GAGE3 & TEN IS & LONG & GE AR & $\operatorname{sign} x$ & IGI \\
\hline $\begin{array}{l}-0-c-c \\
-0-c-D \\
-0-z-E \\
-0-c-P \\
-0-c-B \\
-0-C-J \\
-0-c-R \\
-0-c-L \\
-0-c-B \\
-0-c-P \\
-0-c-S\end{array}$ & $\begin{array}{r}12 \\
0 \\
7 \\
7 \\
0 \\
0 \\
3 \\
0 \\
2 \\
2 \\
2\end{array}$ & $\begin{array}{r}-190 \\
-169 \\
-140 \\
-114 \\
62 \\
39 \\
-28 \\
-17 \\
-10 \\
-5 \\
-2\end{array}$ & $\begin{array}{r}179 \\
160 \\
129 \\
108 \\
-64 \\
-43 \\
24 \\
14 \\
10 \\
5 \\
5\end{array}$ & $\begin{array}{r}-260 \\
-197 \\
-257 \\
-156 \\
-39 \\
-88 \\
-90 \\
-52 \\
-3 \\
-3 \\
50\end{array}$ & $\begin{array}{r}288 \\
-51 \\
143 \\
176 \\
1 \\
-15 \\
57 \\
-16 \\
71 \\
71 \\
87\end{array}$ & $\begin{array}{r}-4925 \\
-4385 \\
-3591 \\
-2956 \\
1684 \\
1080 \\
-703 \\
-413 \\
-254 \\
-127 \\
-95\end{array}$ & $\begin{array}{r}4947 \\
4262 \\
3540 \\
2971 \\
1665 \\
1029 \\
690 \\
380 \\
291 \\
166\end{array}$ & $\begin{array}{l}-491 \\
-451 \\
-365 \\
-295 \\
-170 \\
-113 \\
-72 \\
-44 \\
-22 \\
-9 \\
-2\end{array}$ \\
\hline 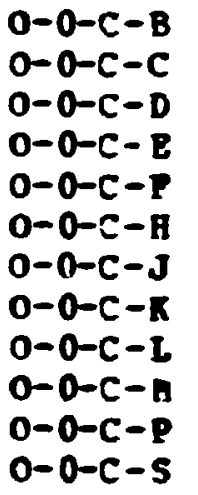 & $\begin{array}{r}5 \\
2 \\
3 \\
3 \\
-2 \\
3 \\
2 \\
0 \\
0 \\
0 \\
0 \\
2\end{array}$ & $\begin{array}{r}-88 \\
-97 \\
-80 \\
-66 \\
-50 \\
-28 \\
-14 \\
-9 \\
-7 \\
-5 \\
-2 \\
0\end{array}$ & $\begin{array}{l}71 \\
88 \\
71 \\
60 \\
52 \\
29 \\
19 \\
14 \\
7 \\
7 \\
2 \\
0\end{array}$ & $\begin{array}{r}-366 \\
-203 \\
-204 \\
-148 \\
62 \\
7 \\
102 \\
104 \\
0 \\
52 \\
0 \\
-3\end{array}$ & $\begin{array}{r}37 \\
14 \\
17 \\
34 \\
-44 \\
80 \\
102 \\
31 \\
0 \\
16 \\
0 \\
70\end{array}$ & $\begin{array}{r}-2118 \\
-2464 \\
-2023 \\
-1677 \\
-1358 \\
-759 \\
-442 \\
-315 \\
-190 \\
-158 \\
-63 \\
0\end{array}$ & $\begin{array}{r}1963 \\
2372 \\
1932 \\
1622 \\
1368 \\
803 \\
544 \\
386 \\
190 \\
193 \\
63 \\
70\end{array}$ & $\begin{array}{r}-229 \\
-256 \\
-212 \\
-173 \\
-135 \\
-71 \\
-34 \\
-25 \\
-19 \\
-12 \\
-6 \\
-\end{array}$ \\
\hline 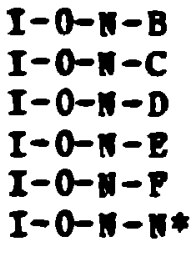 & $\begin{array}{r}79 \\
-10 \\
-26 \\
-24 \\
-22 \\
-153\end{array}$ & $\begin{array}{r}-199 \\
-34 \\
7 \\
12 \\
5 \\
-5\end{array}$ & $\begin{array}{r}172 \\
-2 \\
-34 \\
-17 \\
-2 \\
0\end{array}$ & $\begin{array}{r}-666 \\
-779 \\
-550 \\
-79 \\
76 \\
63\end{array}$ & $\begin{array}{r}2171 \\
-521 \\
-955 \\
-742 \\
-624 \\
-4579\end{array}$ & $\begin{array}{r}-4945 \\
-415 \\
542 \\
383 \\
96 \\
-64\end{array}$ & $\begin{array}{r}5897 \\
-216 \\
-174 \\
96 \\
89 \\
64\end{array}$ & $\begin{array}{l}-43 \\
-10 \\
-13 \\
-9 \\
-6 \\
-45\end{array}$ \\
\hline 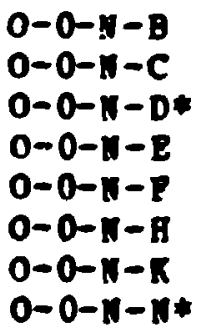 & $\begin{array}{r}-2 \\
2 \\
2 \\
0 \\
5 \\
2 \\
-5 \\
0\end{array}$ & $\begin{array}{r}64 \\
40 \\
749 \\
2 \\
0 \\
0 \\
0 \\
0\end{array}$ & $\begin{array}{r}-88 \\
-45 \\
-9 \\
0 \\
0 \\
-2 \\
-5 \\
0\end{array}$ & $\begin{array}{r}-519 \\
-107 \\
16252 \\
52 \\
-5 \\
-55 \\
-99 \\
0\end{array}$ & $\begin{array}{r}-227 \\
39 \\
4947 \\
16 \\
141 \\
55 \\
-172 \\
0\end{array}$ & $\begin{array}{r}2022 \\
1138 \\
10108 \\
32 \\
0 \\
32 \\
63 \\
0\end{array}$ & $\begin{array}{r}1655 \\
1100 \\
22181 \\
70 \\
141 \\
63 \\
-63 \\
0\end{array}$ & $\begin{array}{r}-240 \\
-117 \\
-98 \\
- \\
-6 \\
-20\end{array}$ \\
\hline
\end{tabular}


Table í.2 (continued)

OOT-OP-PLANE HOAENT LOADING, HTH, ON NOZZLE (400 IM-LB)

HICRO-STRATN

$-\infty-\infty-\infty-\infty$
STRESSES

$\rightarrow-\infty$

TRA IS

GAGE 3

$$
\text { rr }
$$

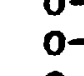

\begin{tabular}{|c|c|c|c|c|c|c|c|c|}
\hline ROSETTE & E1 & GAGE & GAGE3 & TRA WS & IOIG & SREAR & SIGRX & SIGHA \\
\hline $\begin{array}{l}I-90 C-B \\
I-90 C-C \\
I-90 C-D \\
I-90 C-B \\
I-90 C-P \\
I-90 C-R\end{array}$ & $\begin{array}{l}-17 \\
-46 \\
-34 \\
-31 \\
-22 \\
7\end{array}$ & $\begin{array}{r}-247 \\
-192 \\
-137 \\
-98 \\
-100 \\
2\end{array}$ & $\begin{array}{r}-227 \\
0 \\
-132 \\
-91 \\
-67 \\
2\end{array}$ & $\begin{array}{r}-10402 \\
-4163 \\
-5866 \\
-4136 \\
-3652 \\
81\end{array}$ & $\begin{array}{r}-3635 \\
-2624 \\
-2774 \\
-2186 \\
-1754 \\
226\end{array}$ & $\begin{array}{r}-256 \\
-2554 \\
-63 \\
-96 \\
-436 \\
1\end{array}$ & $\begin{array}{r}-3625 \\
-726 \\
-2772 \\
-2181 \\
-1658 \\
226\end{array}$ & $\begin{array}{r}-10411 \\
-6061 \\
-5867 \\
-4141 \\
-3748 \\
81\end{array}$ \\
\hline $\begin{array}{l}0-90 C-B \\
0-90 C-C \\
0-90 C-D \\
0-90 C-B \\
0-90 C-P \\
0-90 C-B\end{array}$ & $\begin{array}{l}76 \\
88 \\
85 \\
80 \\
71 \\
-3\end{array}$ & $\begin{array}{l}223 \\
199 \\
168 \\
123 \\
102 \\
-5\end{array}$ & $\begin{array}{r}258 \\
213 \\
0 \\
130 \\
102 \\
1\end{array}$ & $\begin{array}{r}10493 \\
8971 \\
3604 \\
5484 \\
4400 \\
-78\end{array}$ & $\begin{array}{l}5424 \\
5317 \\
3636 \\
1058 \\
3450 \\
-104\end{array}$ & $\begin{array}{r}-474 \\
-191 \\
2242 \\
-96 \\
-1 \\
-86\end{array}$ & $\begin{array}{r}10537 \\
8981 \\
5862 \\
5491 \\
4400 \\
-4\end{array}$ & $\begin{array}{r}5380 \\
5307 \\
1378 \\
4051 \\
3450 \\
-178\end{array}$ \\
\hline $\begin{array}{l}I-90 N-B \\
I-90 N-C \\
I-90 N-D \\
I-90 N-E \\
I-90 N-P * \\
I-90 N-N\end{array}$ & $\begin{array}{r}-594 \\
127 \\
246 \\
215 \\
24 \\
170\end{array}$ & $\begin{array}{r}72 \\
122 \\
62 \\
-5 \\
-28 \\
84\end{array}$ & $\begin{array}{r}-74 \\
122 \\
100 \\
45 \\
3 \\
48\end{array}$ & $\begin{array}{r}500 \\
5214 \\
3294 \\
655 \\
-588 \\
2700\end{array}$ & $\begin{array}{r}-17645 \\
5364 \\
8358 \\
6635 \\
555 \\
5895\end{array}$ & $\begin{array}{r}1939 \\
0 \\
-508 \\
-667 \\
-415 \\
477\end{array}$ & $\begin{array}{r}804 \\
5364 \\
8409 \\
6709 \\
690 \\
5965\end{array}$ & $\begin{array}{r}-17849 \\
5214 \\
3244 \\
582 \\
-723 \\
2630\end{array}$ \\
\hline $\begin{array}{l}0-90 N-B \\
0-90 N-C \\
0-90 N-D \\
0-90 N-E \\
0-90 N-B \\
0-90 N-A\end{array}$ & $\begin{array}{r}258 \\
59 \\
95 \\
107 \\
130 \\
130\end{array}$ & $\begin{array}{r}401 \\
111 \\
14 \\
-7 \\
38 \\
0\end{array}$ & $\begin{array}{r}403 \\
118 \\
14 \\
-2 \\
5 \\
7\end{array}$ & $\begin{array}{r}17388 \\
4983 \\
510 \\
-326 \\
795 \\
13\end{array}$ & $\begin{array}{r}12968 \\
3268 \\
2991 \\
3105 \\
4153 \\
3918\end{array}$ & $\begin{array}{r}-31 \\
-94 \\
1 \\
-63 \\
443 \\
-95\end{array}$ & $\begin{array}{r}17388 \\
4988 \\
2991 \\
3106 \\
4210 \\
3921\end{array}$ & $\begin{array}{r}12967 \\
3263 \\
510 \\
-327 \\
738 \\
11\end{array}$ \\
\hline
\end{tabular}


Table A.2 (continted)

\begin{tabular}{|c|c|c|c|c|c|c|c|c|}
\hline \multirow[b]{2}{*}{ ROSET TE } & \multicolumn{3}{|c|}{ EICRO-STRA In } & \multicolumn{3}{|c|}{ STRESSES } & \multicolumn{2}{|c|}{ PRIN STRESSES } \\
\hline & $\begin{array}{l}\text { GAGEI } \\
-\end{array}$ & $\begin{array}{l}\text { GAGE2 } \\
-\end{array}$ & GAGE 3 & TRIIS & LOIG & SHEAR & SIGAX & SIGHE \\
\hline $\begin{array}{l}180 C-B \\
180 C-C \\
180 C-D \\
180 C-E \\
180 C-P \\
180 C-S\end{array}$ & $\begin{array}{r}-19 \\
-12 \\
-10 \\
-3 \\
-3 \\
2\end{array}$ & $\begin{array}{r}162 \\
212 \\
167 \\
141 \\
115 \\
4\end{array}$ & $\begin{array}{r}-130 \\
-165 \\
-142 \\
-123 \\
-97 \\
-1\end{array}$ & $\begin{array}{r}730 \\
1031 \\
562 \\
397 \\
401 \\
71\end{array}$ & $\begin{array}{r}-357 \\
-55 \\
-131 \\
38 \\
41 \\
66\end{array}$ & $\begin{array}{r}3893 \\
5024 \\
4115 \\
3519 \\
2827 \\
63\end{array}$ & $\begin{array}{r}1118 \\
5541 \\
4345 \\
3741 \\
3054 \\
131\end{array}$ & $\begin{array}{r}-3744 \\
-4565 \\
-3914 \\
-3306 \\
-2611 \\
6\end{array}$ \\
\hline $\begin{array}{l}0180 C-B \\
0180 C-C \\
0180 C-D \\
0180 C-B \\
0180 C-P \\
0180 C-S\end{array}$ & $\begin{array}{r}9 \\
2 \\
4 \\
4 \\
5 \\
22\end{array}$ & $\begin{array}{r}85 \\
90 \\
73 \\
61 \\
53 \\
5\end{array}$ & $\begin{array}{r}-100 \\
-110 \\
-86 \\
-65 \\
-53 \\
0\end{array}$ & $\begin{array}{r}-340 \\
-441 \\
-278 \\
-72 \\
-5 \\
81\end{array}$ & $\begin{array}{r}167 \\
-81 \\
38 \\
104 \\
142 \\
670\end{array}$ & $\begin{array}{r}2471 \\
2664 \\
2122 \\
1679 \\
1402 \\
64\end{array}$ & $\begin{array}{r}2397 \\
2409 \\
2008 \\
1698 \\
1472 \\
677\end{array}$ & $\begin{array}{r}-2570 \\
-2931 \\
-2248 \\
-1666 \\
-1336 \\
75\end{array}$ \\
\hline $\begin{array}{l}I 180 N-B \\
I 180 N-C \\
I 180 N-D \\
I 180 N-E \\
I 180 N-P \\
I 180 N-I\end{array}$ & $\begin{array}{r}-33 \\
2 \\
5 \\
0 \\
0 \\
10\end{array}$ & $\begin{array}{r}246 \\
60 \\
24 \\
-24 \\
-7 \\
2\end{array}$ & $\begin{array}{r}-172 \\
-14 \\
17 \\
12 \\
4 \\
-2\end{array}$ & $\begin{array}{r}1662 \\
993 \\
886 \\
-262 \\
-65 \\
-10\end{array}$ & $\begin{array}{r}-503 \\
370 \\
409 \\
-79 \\
-30 \\
283\end{array}$ & $\begin{array}{r}5561 \\
985 \\
95 \\
-477 \\
-159 \\
64\end{array}$ & $\begin{array}{r}6245 \\
1715 \\
904 \\
315 \\
112 \\
296\end{array}$ & $\begin{array}{r}-5086 \\
-352 \\
391 \\
-656 \\
-207 \\
-24\end{array}$ \\
\hline $\begin{array}{l}0180 N-B \\
0180 N-C \\
0180 N-D \\
0180 N-E \\
0180 N-P \\
0180 N-A\end{array}$ & $\begin{array}{l}7 \\
7 \\
2 \\
2 \\
0 \\
2\end{array}$ & $\begin{array}{r}-77 \\
-36 \\
-5 \\
5 \\
7 \\
2\end{array}$ & $\begin{array}{r}33 \\
31 \\
12 \\
0 \\
-2 \\
2\end{array}$ & $\begin{array}{r}-975 \\
-113 \\
155 \\
102 \\
105 \\
102\end{array}$ & $\begin{array}{r}-77 \\
181 \\
118 \\
102 \\
32 \\
102\end{array}$ & $\begin{array}{r}-1478 \\
-892 \\
-223 \\
64 \\
127 \\
0\end{array}$ & $\begin{array}{r}1019 \\
938 \\
360 \\
166 \\
201 \\
102\end{array}$ & $\begin{array}{r}-2071 \\
-870 \\
-87 \\
39 \\
-64 \\
102\end{array}$ \\
\hline
\end{tabular}


Table A.2 (continued)

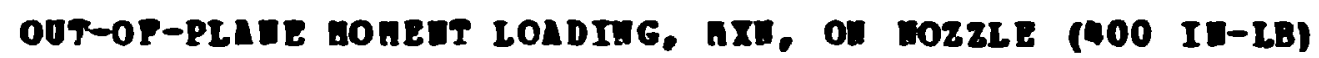

GICRO-STRAIN

-

ROSET TE GIGE1 GRGE2 GIGE3

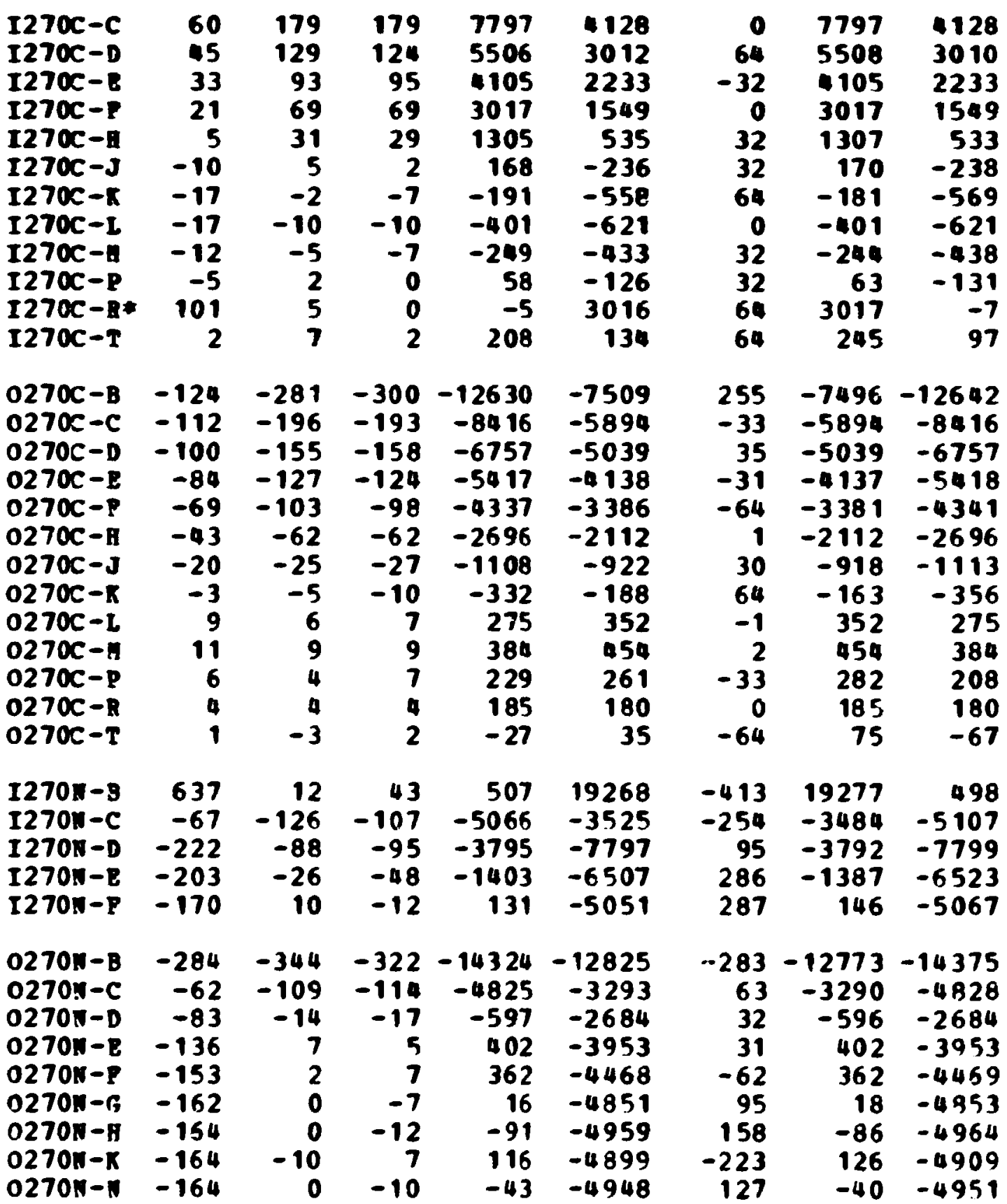

PRI STaEsses

TRA IIS

STRESSES

-- - -

LONG

SAEAP

suena

\begin{tabular}{|c|c|c|c|c|c|c|c|c|}
\hline 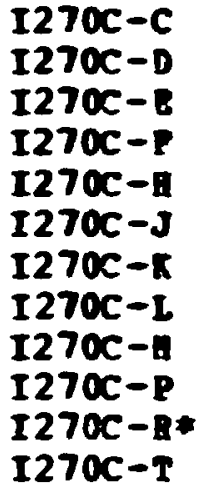 & $\begin{array}{r}60 \\
45 \\
33 \\
21 \\
5 \\
-10 \\
-17 \\
-17 \\
-12 \\
-5 \\
101 \\
2\end{array}$ & $\begin{array}{r}179 \\
129 \\
93 \\
69 \\
31 \\
5 \\
-2 \\
-10 \\
-5 \\
2 \\
5 \\
7\end{array}$ & $\begin{array}{r}179 \\
124 \\
95 \\
69 \\
29 \\
2 \\
-7 \\
-10 \\
-7 \\
0 \\
0 \\
2\end{array}$ & $\begin{array}{r}7797 \\
5506 \\
1105 \\
3017 \\
1305 \\
168 \\
-191 \\
-401 \\
-249 \\
58 \\
-5 \\
208\end{array}$ & $\begin{array}{r}11 \\
30 \\
22 \\
15 \\
5 \\
-2 \\
-5 \\
-6 \\
-4 \\
-1 \\
30 \\
1\end{array}$ & $\begin{array}{r}0 \\
64 \\
-32 \\
0 \\
32 \\
32 \\
64 \\
0 \\
32 \\
32 \\
64 \\
64\end{array}$ & $\begin{array}{r}7797 \\
5508 \\
1105 \\
3017 \\
1307 \\
170 \\
-181 \\
-401 \\
-244 \\
63 \\
3017 \\
245\end{array}$ & $\begin{array}{r}1128 \\
3010 \\
2233 \\
1549 \\
533 \\
-238 \\
-569 \\
-621 \\
-438 \\
-131 \\
-7 \\
97\end{array}$ \\
\hline 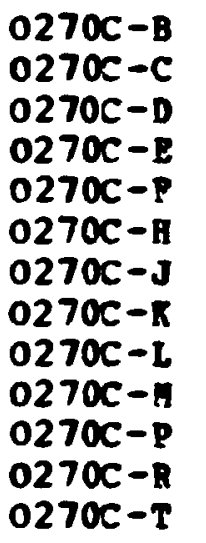 & $\begin{array}{r}-124 \\
-112 \\
-100 \\
-84 \\
-69 \\
-43 \\
-20 \\
-3 \\
9 \\
11 \\
6 \\
4 \\
1\end{array}$ & $\begin{array}{r}-281 \\
-196 \\
-155 \\
-127 \\
-103 \\
-62 \\
-25 \\
-5 \\
6 \\
9 \\
4 \\
4 \\
-3\end{array}$ & $\begin{array}{r}-300 \\
-193 \\
-158 \\
-124 \\
-98 \\
-62 \\
-27 \\
-10 \\
7 \\
9 \\
7 \\
4 \\
2\end{array}$ & $\begin{array}{r}-12630 \\
-8416 \\
-6757 \\
-5417 \\
-4337 \\
-2696 \\
-1108 \\
-332 \\
275 \\
384 \\
229 \\
185 \\
-27\end{array}$ & $\begin{array}{r}-7509 \\
-5894 \\
-5039 \\
-4138 \\
-3386 \\
-2112 \\
-922 \\
-188 \\
352 \\
454 \\
261 \\
180 \\
35\end{array}$ & $\begin{array}{r}255 \\
-33 \\
35 \\
-31 \\
-64 \\
1 \\
30 \\
64 \\
-1 \\
2 \\
-33 \\
0 \\
-64\end{array}$ & $\begin{array}{r}-7496 \\
-5894 \\
-5039 \\
-4137 \\
-3381 \\
-2112 \\
-918 \\
-163 \\
352 \\
454 \\
282 \\
185 \\
75\end{array}$ & $\begin{array}{r}-12642 \\
-8416 \\
-6757 \\
-5418 \\
-4341 \\
-2696 \\
-1113 \\
-356 \\
275 \\
384 \\
208 \\
180 \\
-67\end{array}$ \\
\hline $\begin{array}{l}-3 \\
-C \\
-B \\
-B \\
-B\end{array}$ & $\begin{array}{r}637 \\
-67 \\
-222 \\
-203 \\
-170\end{array}$ & $\begin{array}{r}12 \\
-126 \\
-88 \\
-26 \\
10\end{array}$ & $\begin{array}{r}43 \\
-107 \\
-95 \\
-48 \\
-12\end{array}$ & $\begin{array}{r}507 \\
-5066 \\
-3795 \\
-1403 \\
131\end{array}$ & $\begin{array}{l}19 \\
-3 \\
-7 \\
-6 \\
-5\end{array}$ & $\begin{array}{r}-413 \\
-254 \\
95 \\
286 \\
287\end{array}$ & $\begin{array}{r}19277 \\
-3484 \\
-3792 \\
-1387 \\
146\end{array}$ & $\begin{array}{r}498 \\
-5107 \\
-7799 \\
-6523 \\
-5067\end{array}$ \\
\hline $\begin{array}{l}-B \\
-C \\
-C \\
-D \\
-B \\
-B \\
-C \\
-B \\
-B \\
-K \\
-K\end{array}$ & $\begin{array}{r}-284 \\
-62 \\
-83 \\
-136 \\
-153 \\
-162 \\
-154 \\
-164 \\
-164\end{array}$ & $\begin{array}{r}-344 \\
-109 \\
-14 \\
7 \\
2 \\
0 \\
0 \\
-10\end{array}$ & $\begin{array}{r}-322 \\
-114 \\
-17 \\
5 \\
7 \\
-7 \\
-12 \\
7 \\
-10\end{array}$ & $\begin{array}{r}-14324 \\
-4825 \\
-597 \\
402 \\
362 \\
16 \\
-91 \\
116 \\
-43\end{array}$ & $\begin{array}{l}-128 \\
-32 \\
-26 \\
-39 \\
-44 \\
-48 \\
-49 \\
-48 \\
-49\end{array}$ & $\begin{array}{r}-283 \\
63 \\
32 \\
31 \\
-62 \\
95 \\
158 \\
-223 \\
127\end{array}$ & $\begin{array}{r}-12773 \\
-3290 \\
-596 \\
402 \\
362 \\
18 \\
-86 \\
126 \\
-40\end{array}$ & $\begin{array}{r}-14375 \\
-4828 \\
-2684 \\
-3953 \\
-4459 \\
-4953 \\
-4964 \\
-4909 \\
-4951\end{array}$ \\
\hline
\end{tabular}


Tabie A.2 (continued)

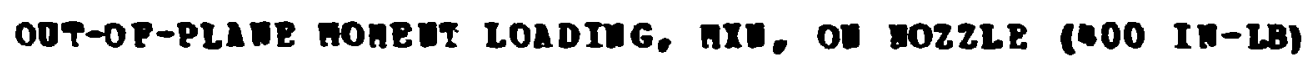

\begin{tabular}{|c|c|c|c|c|c|c|c|c|}
\hline \multirow[b]{2}{*}{ ROSET TE } & \multicolumn{3}{|c|}{ nICRo-sTan In } & \multicolumn{3}{|c|}{ STRESSES } & \multicolumn{2}{|c|}{ PRIN STRESSES } \\
\hline & GAGEI & GLGE2 & GIGE 3 & PRAMS & LOEG & SAE AR & SIGnx & SIG \\
\hline $\begin{array}{l}5 C-B \\
5 C-C \\
5 C-D \\
5 C-B \\
5 C-B \\
5 C-J \\
5 C-R \\
5 C-I \\
5 C-1 \\
5 C-B\end{array}$ & $\begin{array}{r}41 \\
33 \\
31 \\
50 \\
62 \\
60 \\
53 \\
0 \\
-5 \\
-5\end{array}$ & $\begin{array}{r}11 \\
12 \\
5 \\
41 \\
41 \\
45 \\
48 \\
2 \\
8 \\
0\end{array}$ & $\begin{array}{r}284 \\
275 \\
191 \\
86 \\
100 \\
86 \\
76 \\
36 \\
21 \\
2\end{array}$ & $\begin{array}{r}7091 \\
6260 \\
4272 \\
2726 \\
3028 \\
2820 \\
2671 \\
836 \\
657 \\
47\end{array}$ & $\begin{array}{r}3345 \\
2881 \\
2213 \\
2322 \\
2771 \\
2637 \\
2377 \\
251 \\
45 \\
-147\end{array}$ & $\begin{array}{r}-3245 \\
-3499 \\
-2479 \\
-604 \\
-795 \\
-541 \\
-382 \\
-441 \\
-174 \\
-25\end{array}$ & $\begin{array}{l}8965 \\
8456 \\
5927 \\
3161 \\
3705 \\
3277 \\
2933\end{array}$ & $\begin{array}{r}1472 \\
684 \\
558 \\
1887 \\
2093 \\
2180 \\
2115 \\
14 \\
-1 \\
-150\end{array}$ \\
\hline $\begin{array}{l}5 C-B \\
5 C-C \\
5 C-D \\
5 C-B \\
5 C-B \\
5 C-B \\
5 C-R \\
5 C-L \\
5 C-A \\
5 C-P\end{array}$ & $\begin{array}{l}-55 \\
-50 \\
-38 \\
-26 \\
-28 \\
-14 \\
-7 \\
-7 \\
-7 \\
-2\end{array}$ & $\begin{array}{r}-228 \\
-199 \\
-209 \\
-176 \\
-145 \\
-109 \\
-45 \\
-24 \\
-9 \\
2\end{array}$ & $\begin{array}{l}-64 \\
-47 \\
-47 \\
-45 \\
-33 \\
-31 \\
-21 \\
-17 \\
-12 \\
-2\end{array}$ & $\begin{array}{r}-6353 \\
-5367 \\
-5589 \\
-4820 \\
-3879 \\
-3060 \\
-1452 \\
-878 \\
-461 \\
3\end{array}$ & $\begin{array}{r}-3543 \\
-3105 \\
-2816 \\
-2229 \\
-2018 \\
-1345 \\
-649 \\
-477 \\
-352 \\
-70\end{array}$ & $\begin{array}{r}-2181 \\
-2023 \\
-2149 \\
-1738 \\
-1486 \\
-1043 \\
-316 \\
-95 \\
32 \\
63\end{array}$ & $\begin{array}{r}-2353 \\
-1918 \\
-1644 \\
-1356 \\
-1195 \\
-852 \\
-540 \\
-456 \\
-343 \\
39\end{array}$ & $\begin{array}{l}-7542 \\
-6554 \\
-6760 \\
-5693 \\
-4701 \\
-3553 \\
-1561 \\
-900 \\
-470 \\
-107\end{array}$ \\
\hline $\begin{array}{l}-7 \\
1-8 \\
1-C \\
-B \\
-B\end{array}$ & $\begin{array}{r}440 \\
-62 \\
-165 \\
-149 \\
-125 \\
-125\end{array}$ & $\begin{array}{r}-136 \\
-96 \\
-51 \\
-12 \\
0 \\
4\end{array}$ & $\begin{array}{r}79 \\
-108 \\
-94 \\
-43 \\
-17 \\
11\end{array}$ & $\begin{array}{r}-1749 \\
-4408 \\
-2984 \\
-1059 \\
-245 \\
480\end{array}$ & $\begin{array}{l}12664 \\
-3195 \\
-5851 \\
-4774 \\
-3812 \\
-3591\end{array}$ & $\begin{array}{r}-2865 \\
160 \\
573 \\
412 \\
222 \\
-96\end{array}$ & $\begin{array}{r}13213 \\
-3175 \\
-2874 \\
-1014 \\
-231 \\
482\end{array}$ & $\begin{array}{l}-2297 \\
-4428 \\
-5961 \\
-4819 \\
-3826 \\
-3593\end{array}$ \\
\hline $\begin{array}{l}0315 n-B \\
0315 n-C \\
0315 n-D \\
0315 n-E \\
0315 n-P \\
0315 N-G \\
0315 n-R \\
0315 n-R \\
0315 N-R\end{array}$ & $\begin{array}{r}-209 \\
-36 \\
-56 \\
-91 \\
-112 \\
-122 \\
-117 \\
-117 \\
-618\end{array}$ & $\begin{array}{r}-218 \\
-57 \\
5 \\
16 \\
10 \\
3 \\
3 \\
3 \\
10\end{array}$ & $\begin{array}{r}-368 \\
-128 \\
.76 \\
3 \\
5 \\
-4 \\
-7 \\
-11 \\
-11\end{array}$ & $\begin{array}{r}-12648 \\
-4027 \\
-393 \\
516 \\
444 \\
96 \\
34 \\
-65 \\
640\end{array}$ & $\begin{array}{r}-10058 \\
-2276 \\
-1801 \\
-2586 \\
-3237 \\
-3623 \\
-3502 \\
-3533 \\
-18353\end{array}$ & $\begin{array}{r}1991 \\
948 \\
404 \\
185 \\
63 \\
95 \\
125 \\
186 \\
281\end{array}$ & $\begin{array}{r}-8977 \\
-1861 \\
-286 \\
527 \\
445 \\
98 \\
38 \\
-55 \\
644\end{array}$ & $\begin{array}{r}-13728 \\
-4442 \\
-1909 \\
-2597 \\
-3238 \\
-3626 \\
-3506 \\
-3543 \\
-18357\end{array}$ \\
\hline
\end{tabular}


Table A.3. Torsional mont loading, MK. on nozzle

\begin{tabular}{|c|c|c|c|c|c|c|c|c|}
\hline \multirow[b]{2}{*}{ BOSETTE } & \multicolumn{3}{|c|}{ Arcao-stwitn } & \multicolumn{3}{|c|}{ STRESSES } & \multicolumn{2}{|c|}{ PRIN STRESSES } \\
\hline & G & 1GE2 & & & LONG & iaEAR & $\operatorname{sign} x$ & IGE \\
\hline $\begin{array}{l}I-0-C-C \\
I-0-C-D \\
I-0-C-I \\
I-0-C-P \\
I-0-C-B \\
I-0-C-J \\
I-0-C-I \\
I-0-C-I \\
I-0-C-I \\
I-0-C-P \\
I-0-C-S\end{array}$ & $\begin{array}{r}7 \\
2 \\
2 \\
0 \\
-3 \\
0 \\
2 \\
-112 \\
2 \\
2 \\
2\end{array}$ & $\begin{array}{r}-24 \\
-27 \\
-22 \\
-17 \\
19 \\
16 \\
-5 \\
-5 \\
-5 \\
-1 \\
-1\end{array}$ & $\begin{array}{r}47 \\
47 \\
35 \\
29 \\
-10 \\
-10 \\
11 \\
9 \\
9 \\
4 \\
3\end{array}$ & $\begin{array}{l}499 \\
454 \\
297 \\
251 \\
197 \\
137 \\
134 \\
207 \\
138 \\
76 \\
40\end{array}$ & $\begin{array}{r}354 \\
198 \\
154 \\
66 \\
-27 \\
28 \\
98 \\
-3300 \\
99 \\
79 \\
61\end{array}$ & $\begin{array}{r}-954 \\
-986 \\
-763 \\
-603 \\
381 \\
350 \\
-219 \\
-190 \\
-160 \\
-61 \\
-42\end{array}$ & $\begin{array}{r}1383 \\
1320 \\
992 \\
768 \\
483 \\
437 \\
335 \\
217 \\
280 \\
138 \\
94\end{array}$ & $\begin{array}{r}-530 \\
-658 \\
-540 \\
-451 \\
-312 \\
-272 \\
-104 \\
-3311 \\
-8 ? \\
16\end{array}$ \\
\hline $\begin{array}{l}0-0-C-B \\
-0-C-C \\
-0-C-D \\
-0-C-E \\
-0-C-P \\
-0-C-B \\
-0-C-J \\
-0-C-R \\
-0-C-I \\
-0-C-B \\
-0-C-P \\
-0-C-S\end{array}$ & $\begin{array}{l}-9 \\
-2 \\
-2 \\
-2 \\
1 \\
-2 \\
-2 \\
-2 \\
-2 \\
-2 \\
-2 \\
-2\end{array}$ & $\begin{array}{r}192 \\
50 \\
31 \\
17 \\
8 \\
3 \\
0 \\
-2 \\
-2 \\
1 \\
-2 \\
-2\end{array}$ & $\begin{array}{r}-230 \\
-85 \\
-56 \\
-40 \\
-30 \\
-16 \\
-6 \\
-4 \\
-4 \\
-4 \\
-2 \\
-2\end{array}$ & $\begin{array}{l}-813 \\
-759 \\
-554 \\
-494 \\
-504 \\
-288 \\
-129 \\
-129 \\
-132 \\
-80 \\
-82 \\
-80\end{array}$ & $\begin{array}{l}-517 \\
-290 \\
-222 \\
-203 \\
-133 \\
-142 \\
-86 \\
-90 \\
-88 \\
-77 \\
-77 \\
-70\end{array}$ & $\begin{array}{r}5619 \\
1801 \\
1166 \\
753 \\
505 \\
252 \\
90 \\
31 \\
32 \\
64 \\
-2 \\
0\end{array}$ & $\begin{array}{r}4956 \\
1292 \\
790 \\
419 \\
220 \\
47 \\
-15 \\
-73 \\
-71 \\
-14 \\
-76 \\
-70\end{array}$ & $\begin{array}{r}-6286 \\
-2341 \\
-1566 \\
-1116 \\
-857 \\
-478 \\
-200 \\
-146 \\
-150 \\
-143 \\
-82 \\
-90\end{array}$ \\
\hline $\begin{array}{l}-O-N-B \\
{[-C-N-C} \\
-0-N-D \\
-0-N-B \\
-0-N-P \\
{[-C-N-N}\end{array}$ & $\begin{array}{r}57 \\
-22 \\
-31 \\
-39 \\
-34 \\
24\end{array}$ & $\begin{array}{l}-213 \\
-319 \\
-335 \\
-326 \\
-326 \\
-348\end{array}$ & $\begin{array}{l}220 \\
306 \\
309 \\
337 \\
34 C \\
335\end{array}$ & $\begin{array}{r}94 \\
-246 \\
-549 \\
300 \\
344 \\
-304\end{array}$ & $\begin{array}{r}1740 \\
-732 \\
-1108 \\
-1069 \\
-909 \\
619\end{array}$ & $\begin{array}{l}-5775 \\
-8329 \\
-8583 \\
-8836 \\
-8872 \\
-9094\end{array}$ & $\begin{array}{l}6746 \\
7844 \\
7759 \\
8479 \\
8612 \\
9263\end{array}$ & $\begin{array}{l}-4923 \\
-8821 \\
-9416 \\
-9247 \\
-9177 \\
-8948\end{array}$ \\
\hline 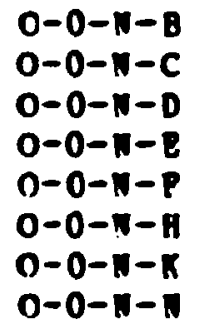 & $\begin{array}{r}5 \\
20 \\
8 \\
10 \\
19 \\
-16 \\
-9 \\
-52\end{array}$ & $\begin{array}{l}40= \\
394 \\
373 \\
375 \\
387 \\
413 \\
403 \\
401\end{array}$ & $\begin{array}{l}-493 \\
-417 \\
-433 \\
-414 \\
-414 \\
-395 \\
-398 \\
-370\end{array}$ & $\begin{array}{r}-1955 \\
-511 \\
-1343 \\
-882 \\
-623 \\
395 \\
124 \\
734\end{array}$ & $\begin{array}{r}-434 \\
432 \\
-173 \\
35 \\
256 \\
-367 \\
-225 \\
-1331\end{array}$ & $\begin{array}{l}11941 \\
10805 \\
10738 \\
10517 \\
10670 \\
10766 \\
10574 \\
10274\end{array}$ & $\begin{array}{r}10765 \\
10776 \\
9976 \\
10103 \\
10496 \\
10787 \\
10624 \\
10028\end{array}$ & $\begin{array}{l}-13165 \\
-10855 \\
-11512 \\
-10950 \\
-10862 \\
-10758 \\
-10726 \\
-10625\end{array}$ \\
\hline
\end{tabular}


Fable A.3 (continued)

\begin{tabular}{|c|c|c|c|c|c|c|c|c|}
\hline \multirow[b]{2}{*}{ DOSETTE } & \multicolumn{3}{|c|}{ Ircho-sqBate } & \multicolumn{3}{|c|}{ STRESSES } & \multicolumn{2}{|c|}{ PRIN STRESSES } \\
\hline & GAGE 1 & GRGE2 & GAGE3 & RAnS & LONG & SAEAR & $\operatorname{sign} x$ & SIGnx \\
\hline $\begin{array}{l}x c-B \\
x-C \\
x-D \\
x-E \\
x-E \\
x-B\end{array}$ & $\begin{array}{r}-7 \\
-10 \\
-7 \\
-2 \\
-2 \\
2\end{array}$ & $\begin{array}{r}-69 \\
-115 \\
-96 \\
-74 \\
-29 \\
c\end{array}$ & $\begin{array}{r}45 \\
0 \\
91 \\
72 \\
55 \\
0\end{array}$ & $\begin{array}{r}-519 \\
-2513 \\
-97 \\
-50 \\
581 \\
-3\end{array}$ & $\begin{array}{r}-371 \\
-1041 \\
-245 \\
-87 \\
103 \\
71\end{array}$ & $\begin{array}{l}-1 \\
-1 \\
-2 \\
-1 \\
-1\end{array}$ & $\begin{array}{r}1088 \\
-79 \\
2317 \\
1876 \\
1483 \\
71\end{array}$ & $\begin{array}{r}-1976 \\
-3475 \\
-2658 \\
-2013 \\
-799 \\
-3\end{array}$ \\
\hline $\begin{array}{l}x-B \\
x-C \\
x-D \\
c-8 \\
x-P \\
x-8\end{array}$ & $\begin{array}{l}-18 \\
-4 \\
-2 \\
-4 \\
-2 \\
-2\end{array}$ & $\begin{array}{r}138 \\
74 \\
57 \\
56 \\
48 \\
-4\end{array}$ & $\begin{array}{l}-82 \\
-52 \\
-40 \\
-38 \\
-38 \\
-4\end{array}$ & $\begin{array}{r}1193 \\
484 \\
383 \\
276 \\
220 \\
-172\end{array}$ & $\begin{array}{r}-189 \\
13 \\
54 \\
-49 \\
2 \\
-112\end{array}$ & $\begin{array}{l}1677 \\
1294 \\
1171 \\
1138 \\
-10\end{array}$ & $\begin{array}{l}53 \\
42 \\
23 \\
96 \\
55 \\
10\end{array}$ & $\begin{array}{r}-2549 \\
-1445 \\
-1086 \\
-1068 \\
-1033 \\
-174\end{array}$ \\
\hline $\begin{array}{l}\text { B } \\
\text { C } \\
-D \\
-\mathbf{E} \\
-\mathbf{P} \\
-\mathbf{n}\end{array}$ & $\begin{array}{r}-92 \\
-68 \\
-62 \\
-66 \\
11 \\
86\end{array}$ & $\begin{array}{r}-270 \\
-310 \\
-326 \\
-338 \\
-5 \\
-176\end{array}$ & $\begin{array}{r}303 \\
408 \\
412 \\
400 \\
2 \\
117\end{array}$ & $\begin{array}{r}843 \\
2194 \\
1957 \\
1439 \\
-83 \\
-1386\end{array}$ & $\begin{array}{r}-2521 \\
-782 \\
-1259 \\
-1559 \\
314 \\
2176\end{array}$ & $\begin{array}{r}-7631 \\
-9566 \\
-9846 \\
-9843 \\
-94 \\
-3913\end{array}$ & $\begin{array}{r}6975 \\
10387 \\
10325 \\
9897 \\
335 \\
4694\end{array}$ & $\begin{array}{r}-8554 \\
-8975 \\
-9627 \\
-10017 \\
-104 \\
-3904\end{array}$ \\
\hline $\begin{array}{l}0- \\
0- \\
0- \\
0- \\
0-\end{array}$ & $\begin{array}{r}5 \\
22 \\
24 \\
89 \\
91\end{array}$ & $\begin{array}{l}437 \\
375 \\
385 \\
394 \\
212\end{array}$ & $\begin{array}{l}-420 \\
-398 \\
-396 \\
-208 \\
-242 \\
-251\end{array}$ & $\begin{array}{r}370 \\
-584 \\
-273 \\
3992 \\
-753\end{array}$ & $\begin{array}{l}265 \\
474 \\
641 \\
3860 \\
2499 \\
3450\end{array}$ & $\begin{array}{r}11413 \\
10274 \\
10400 \\
8029 \\
6039 \\
8218\end{array}$ & $\begin{array}{r}11730 \\
10232 \\
10594 \\
11956 \\
7128 \\
11173\end{array}$ & $\begin{array}{r}-11095 \\
-10342 \\
-10225 \\
-4103 \\
-5381 \\
-5295\end{array}$ \\
\hline
\end{tabular}


Tatie A.3 (continued)

\begin{tabular}{|c|c|c|c|c|c|c|c|c|}
\hline \multirow[b]{2}{*}{ BoserTE } & \multicolumn{3}{|c|}{ GrCRo-sidnin } & \multicolumn{3}{|c|}{ STRESSES } & \multicolumn{2}{|c|}{ PRTU STEESSES } \\
\hline & GE1 & GAGE & & $\ln 5$ & Lo & SAEAR & SIGRX & SIGaI \\
\hline $\begin{array}{l}:-8 \\
:-C \\
:-0 \\
:-2 \\
:-P \\
:-5\end{array}$ & $\begin{array}{l}0 \\
0 \\
5 \\
5 \\
2 \\
0\end{array}$ & $\begin{array}{l}-17 \\
-45 \\
-39 \\
-28 \\
-21 \\
-2\end{array}$ & $\begin{array}{r}-2 \\
7 \\
5 \\
7 \\
5 \\
2\end{array}$ & $\begin{array}{r}-981 \\
-829 \\
-523 \\
-471 \\
-365 \\
0\end{array}$ & $\begin{array}{r}-264 \\
-209 \\
-16 \\
0 \\
-39 \\
0\end{array}$ & $\begin{array}{r}94 \\
-651 \\
-565 \\
-471 \\
-345 \\
-63\end{array}$ & $\begin{array}{r}-250 \\
211 \\
350 \\
291 \\
180 \\
53\end{array}$ & $\begin{array}{r}-895 \\
-1288 \\
-889 \\
-762 \\
-584 \\
-63\end{array}$ \\
\hline $\begin{array}{l}C-B \\
C-C \\
C-D \\
C-E \\
C-P \\
C-5\end{array}$ & $\begin{array}{r}12 \\
2 \\
2 \\
0 \\
2 \\
-8\end{array}$ & $\begin{array}{r}210 \\
93 \\
62 \\
43 \\
32 \\
2\end{array}$ & $\begin{array}{r}-202 \\
-57 \\
-36 \\
-24 \\
-1 C \\
2\end{array}$ & $\begin{array}{r}250 \\
780 \\
570 \\
420 \\
503 \\
97\end{array}$ & $\begin{array}{r}34 \\
308 \\
245 \\
128 \\
210 \\
-197\end{array}$ & $\begin{array}{r}5548 \\
1997 \\
1300 \\
887 \\
571 \\
-2\end{array}$ & $\begin{array}{r}5890 \\
2557 \\
1720 \\
1173 \\
946 \\
97\end{array}$ & $\begin{array}{r}-5206 \\
-1465 \\
-900 \\
-525 \\
-232 \\
-197\end{array}$ \\
\hline 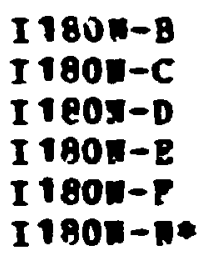 & $\begin{array}{r}-21 \\
91 \\
101 \\
98 \\
109 \\
203\end{array}$ & $\begin{array}{l}-151 \\
-356 \\
-281 \\
-397 \\
-115 \\
-438\end{array}$ & $\begin{array}{l}165 \\
258 \\
245 \\
306 \\
325 \\
218\end{array}$ & $\begin{array}{r}267 \\
-2012 \\
-868 \\
-2123 \\
-2082 \\
-5061\end{array}$ & $\begin{array}{l}-541 \\
2132 \\
2764 \\
2313 \\
2487 \\
4579\end{array}$ & $\begin{array}{l}-8252 \\
-8289 \\
-7019 \\
-9365 \\
-9862 \\
-8733\end{array}$ & $\begin{array}{r}4135 \\
8604 \\
8198 \\
9722 \\
10325 \\
9734\end{array}$ & $\begin{array}{r}-8408 \\
-8484 \\
-6303 \\
-9533 \\
-9921 \\
-10216\end{array}$ \\
\hline $\begin{array}{l}0180 \pi-B \\
0180 \pi-C \\
0180 \pi-D \\
0180 \pi-E \\
0180 \pi-F \\
0180 \pi-1\end{array}$ & $\begin{array}{r}-29 \\
-22 \\
-5 \\
-7 \\
-17 \\
16\end{array}$ & $\begin{array}{l}458 \\
463 \\
435 \\
425 \\
437 \\
409\end{array}$ & $\begin{array}{l}-293 \\
-376 \\
-369 \\
-402 \\
-397 \\
-388\end{array}$ & $\begin{array}{r}3662 \\
1946 \\
1458 \\
1099 \\
903 \\
437\end{array}$ & $\begin{array}{r}234 \\
-65 \\
285 \\
105 \\
-233 \\
619\end{array}$ & $\begin{array}{r}9997 \\
11182 \\
10706 \\
11371 \\
11120 \\
10613\end{array}$ & $\begin{array}{l}12092 \\
12167 \\
11593 \\
11984 \\
11470 \\
11141\end{array}$ & $\begin{array}{r}-8195 \\
-10287 \\
-9851 \\
-10779 \\
-10799 \\
-10085\end{array}$ \\
\hline
\end{tabular}




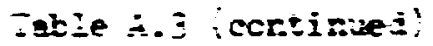

\begin{tabular}{|c|c|c|c|c|c|c|c|c|}
\hline \multirow[b]{2}{*}{ ROSETte } & \multicolumn{3}{|c|}{ nICAO-ST FAIU } & \multicolumn{3}{|c|}{ STRESSES } & \multicolumn{2}{|c|}{ PRIE STEESSES } \\
\hline & & & & & & $\mathbf{E} \mathbf{A R}$ & I GII & $\mathbf{G n}$ \\
\hline $\begin{array}{l}270 C-C \\
270 C-D \\
270 C-E \\
270 C-P \\
270 C-R \\
270 C-J \\
27 \alpha C-R \\
270 C-I \\
270 C-R \\
270 C-P \\
270 C-R * \\
270 C-\mathrm{T}\end{array}$ & $\begin{array}{r}1 \\
1 \\
-1 \\
-1 \\
-1 \\
-1 \\
-2 \\
-2 \\
-1 \\
-3 \\
-62 \\
2\end{array}$ & $\begin{array}{r}-75 \\
-61 \\
-46 \\
-34 \\
-18 \\
-6 \\
1 \\
-2 \\
0 \\
0 \\
5 \\
0\end{array}$ & $\begin{array}{r}82 \\
66 \\
49 \\
37 \\
18 \\
3 \\
-4 \\
-6 \\
-4 \\
1 \\
5 \\
3\end{array}$ & $\begin{array}{r}160 \\
109 \\
62 \\
61 \\
13 \\
-58 \\
-63 \\
-183 \\
7 \\
27 \\
282 \\
58\end{array}$ & $\begin{array}{r}85 \\
69 \\
-17 \\
-16 \\
-26 \\
-52 \\
-59 \\
-101 \\
-27 \\
-72 \\
-1779 \\
90\end{array}$ & $\begin{array}{r}-2096 \\
-1679 \\
-1270 \\
-952 \\
--577 \\
-125 \\
67 \\
55 \\
99 \\
-6 \\
-1 \\
-32\end{array}$ & $\begin{array}{r}2219 \\
1768 \\
1293 \\
975 \\
171 \\
70 \\
1 \\
-72 \\
90 \\
27 \\
282 \\
109\end{array}$ & $\begin{array}{r}-1974 \\
-1591 \\
-1248 \\
-931 \\
-184 \\
-180 \\
-133 \\
-211 \\
-110 \\
-72 \\
-1779 \\
38\end{array}$ \\
\hline 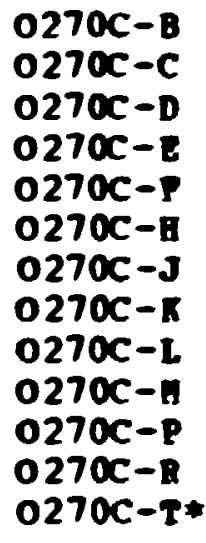 & $\begin{array}{l}-2 \\
1 \\
-7 \\
-2 \\
-4 \\
-4 \\
-2 \\
-2 \\
-2 \\
-2 \\
-2 \\
-2 \\
0\end{array}$ & $\begin{array}{r}155 \\
79 \\
62 \\
53 \\
46 \\
31 \\
20 \\
15 \\
5 \\
0 \\
0 \\
-2 \\
-8\end{array}$ & $\begin{array}{r}-205 \\
-95 \\
-73 \\
-61 \\
-52 \\
-40 \\
-26 \\
-16 \\
-7 \\
-2 \\
C \\
0 \\
C\end{array}$ & $\begin{array}{r}-1188 \\
-345 \\
-232 \\
-182 \\
-129 \\
-178 \\
-123 \\
-29 \\
-23 \\
-48 \\
5 \\
-18 \\
-51\end{array}$ & $\begin{array}{r}-419 \\
-87 \\
-267 \\
-181 \\
-165 \\
-177 \\
-89 \\
-63 \\
-62 \\
-84 \\
-67 \\
-84 \\
-13\end{array}$ & $\begin{array}{r}4848 \\
2314 \\
1803 \\
1520 \\
1299 \\
950 \\
604 \\
412 \\
159 \\
31 \\
0 \\
-32 \\
-31\end{array}$ & $\begin{array}{r}4060 \\
2102 \\
1553 \\
1339 \\
1152 \\
772 \\
499 \\
365 \\
118 \\
-30 \\
5 \\
-29\end{array}$ & $\begin{array}{r}-5666 \\
-2534 \\
-2053 \\
-1702 \\
-1446 \\
-1127 \\
-710 \\
-458 \\
-203 \\
-102 \\
-67 \\
-103 \\
-68\end{array}$ \\
\hline $\begin{array}{l}270 n-8 \\
270 n-C \\
270 n-D \\
270 n-8 \\
270 n-P\end{array}$ & $\begin{array}{r}7 \\
-17 \\
-27 \\
-29 \\
-35\end{array}$ & $\begin{array}{l}-213 \\
-313 \\
-322 \\
-315 \\
-304\end{array}$ & $\begin{array}{l}226 \\
339 \\
346 \\
344 \\
354\end{array}$ & $\begin{array}{r}295 \\
588 \\
548 \\
555 \\
1143\end{array}$ & $\begin{array}{r}291 \\
-334 \\
-633 \\
-673 \\
-717\end{array}$ & $\begin{array}{l}-8 \\
-8 \\
-8 \\
-8\end{array}$ & $\begin{array}{l}6145 \\
8819 \\
8882 \\
8792 \\
9029\end{array}$ & $\begin{array}{l}-5 \\
-85 \\
-8 \\
-88 \\
-86\end{array}$ \\
\hline $\begin{array}{l}0270 N-B \\
0270 N-C \\
0270 N-D \\
0270 N-E \\
0270 N-P \\
0270 N-G \\
0270 n-B \\
0270 n-R= \\
0270 N-R\end{array}$ & $\begin{array}{r}-16 \\
3 \\
-9 \\
-36 \\
-12 \\
5 \\
3 \\
-31 \\
17\end{array}$ & $\begin{array}{l}358 \\
351 \\
362 \\
369 \\
357 \\
359 \\
367 \\
396 \\
355\end{array}$ & $\begin{array}{l}-360 \\
-341 \\
-361 \\
-352 \\
-354 \\
-373 \\
-385 \\
-359 \\
-392\end{array}$ & $\begin{array}{r}-19 \\
219 \\
19 \\
413 \\
79 \\
-314 \\
-411 \\
881 \\
-841\end{array}$ & $\begin{array}{r}-484 \\
146 \\
-272 \\
-941 \\
-323 \\
52 \\
-44 \\
-653 \\
258\end{array}$ & $\begin{array}{r}9573 \\
9221 \\
9635 \\
9604 \\
9476 \\
9762 \\
10016 \\
10081 \\
9952\end{array}$ & $\begin{array}{r}9324 \\
9404 \\
9509 \\
9364 \\
9356 \\
9633 \\
9790 \\
10224 \\
9676\end{array}$ & $\begin{array}{r}-9827 \\
-9039 \\
-9762 \\
-9892 \\
-9600 \\
-9895 \\
-10245 \\
-9996 \\
-10259\end{array}$ \\
\hline
\end{tabular}


Fabie h.j (continised)

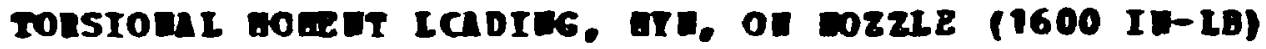

nICRO-STERIE

$-\infty-\infty$
STRESSES

$-\infty-\infty$

PEI STResses

\begin{tabular}{|c|c|c|c|c|c|c|c|c|}
\hline OSE & & & & & & AELR & I6. & $\mathbf{6}$ \\
\hline $\begin{array}{l}315 c-8 \\
315 C-C \\
315 C-D\end{array}$ & $\begin{array}{r}0 \\
5 \\
7 \\
13 \\
27 \\
22 \\
17 \\
-5 \\
-5 \\
-2\end{array}$ & $\begin{array}{r}31 \\
5 \\
2 \\
25 \\
20 \\
20 \\
17 \\
-2 \\
0 \\
0\end{array}$ & $\begin{array}{r}101 \\
113 \\
78 \\
41 \\
39 \\
31 \\
24 \\
12 \\
5 \\
0\end{array}$ & $\begin{array}{r}2901 \\
2582 \\
1679 \\
1491 \\
1253 \\
1090 \\
890 \\
215 \\
110 \\
3\end{array}$ & $\begin{array}{r}876 \\
925 \\
718 \\
1748 \\
1177 \\
987 \\
783 \\
-79 \\
-110 \\
-71\end{array}$ & $\begin{array}{r}-925 \\
-1431 \\
-959 \\
-159 \\
-256 \\
-159 \\
-95 \\
-191 \\
-64 \\
0\end{array}$ & $\begin{array}{r}3260 \\
3408 \\
2270 \\
1824 \\
1473 \\
1211 \\
946 \\
309 \\
127\end{array}$ & $\begin{array}{r}517 \\
101 \\
127 \\
1114 \\
956 \\
874 \\
727 \\
-173 \\
-127 \\
-71\end{array}$ \\
\hline $\begin{array}{l}\mathbf{P} \\
\mathbf{1} \\
\mathbf{2} \\
\mathbf{2} \\
\mathbf{P}\end{array}$ & $\begin{array}{r}53 \\
48 \\
55 \\
-21 \\
-21 \\
-18 \\
-11 \\
-11 \\
-7 \\
-2\end{array}$ & $\begin{array}{r}155 \\
98 \\
17 \\
3 \\
3 \\
-11 \\
-11 \\
-6 \\
-4 \\
-2\end{array}$ & $\begin{array}{l}-47 \\
-4 \\
-78 \\
-66 \\
-61 \\
-47 \\
-23 \\
-14 \\
-9 \\
-7\end{array}$ & $\begin{array}{r}2312 \\
2000 \\
-1399 \\
-1366 \\
-1251 \\
-1261 \\
-800 \\
-428 \\
-287 \\
-181\end{array}$ & $\begin{array}{r}2279 \\
2041 \\
1232 \\
-1042 \\
-1002 \\
-927 \\
-650 \\
-464 \\
-286 \\
-110\end{array}$ & $\begin{array}{r}2687 \\
1356 \\
1265 \\
917 \\
863 \\
474 \\
124 \\
94 \\
65 \\
66\end{array}$ & $\begin{array}{l}1983 \\
3379 \\
1742 \\
-273 \\
-255 \\
-591 \\
-580 \\
-350 \\
-221 \\
-70\end{array}$ & $\begin{array}{r}-392 \\
666 \\
-1908 \\
-2135 \\
-1998 \\
-1597 \\
-870 \\
-542 \\
-352 \\
-221\end{array}$ \\
\hline $\begin{array}{l}1315 \\
1319 \\
1319 \\
1315 \\
1319 \\
1319\end{array}$ & $\begin{array}{r}84 \\
0 \\
-17 \\
-12 \\
-24 \\
59\end{array}$ & $\begin{array}{l}-220 \\
-316 \\
-335 \\
-332 \\
-339 \\
-264\end{array}$ & $\begin{array}{l}280 \\
311 \\
316 \\
316 \\
330 \\
299\end{array}$ & $\begin{array}{r}-105 \\
-402 \\
-355 \\
-184 \\
712\end{array}$ & $\begin{array}{r}2877 \\
-32 \\
-623 \\
-665 \\
-772 \\
1982\end{array}$ & $\begin{array}{l}-6657 \\
-8345 \\
-8664 \\
-8632 \\
-8919 \\
-7506\end{array}$ & $\begin{array}{l}8758 \\
8277 \\
8152 \\
8223 \\
8446 \\
8880\end{array}$ & $\begin{array}{l}-4659 \\
-8414 \\
-9177 \\
-9042 \\
-9402 \\
-6186\end{array}$ \\
\hline $\begin{array}{l}0315 \\
0315 \\
0315 \\
0315 \\
0315 \\
0315 \\
0315 \\
0315 \\
0315\end{array}$ & $\begin{array}{r}52 \\
60 \\
87 \\
59 \\
35 \\
26 \\
24 \\
21 \\
-51\end{array}$ & $\begin{array}{l}340 \\
352 \\
357 \\
380 \\
376 \\
372 \\
387 \\
371 \\
362\end{array}$ & $\begin{array}{l}-479 \\
-389 \\
-394 \\
-371 \\
-380 \\
-366 \\
-366 \\
-375 \\
-387\end{array}$ & $\begin{array}{r}-3117 \\
-995 \\
-918 \\
140 \\
-138 \\
130 \\
142 \\
-122 \\
-507\end{array}$ & $\begin{array}{r}629 \\
1528 \\
2333 \\
1806 \\
1018 \\
817 \\
840 \\
600 \\
-1681\end{array}$ & $\begin{array}{r}10909 \\
9864 \\
10008 \\
10008 \\
10071 \\
9852 \\
10040 \\
9946 \\
9977\end{array}$ & $\begin{array}{r}9824 \\
10259 \\
10846 \\
11017 \\
10528 \\
10332 \\
10682 \\
10191 \\
8901\end{array}$ & $\begin{array}{l}-12 \\
-9 \\
-9 \\
-9 \\
-9 \\
-9 \\
-9 \\
-9 \\
-11\end{array}$ \\
\hline
\end{tabular}




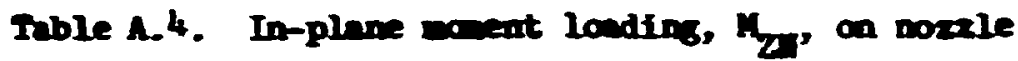

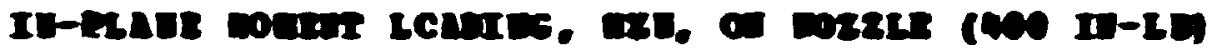

arcoo-srantw

DOSTTE GAGI GASE2 GNEZ3

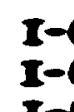$$
\text { 举 }
$$$$
\mathrm{I}-\mathrm{C}-\mathrm{C}-\mathrm{I}
$$$$
\mathrm{I}-\mathrm{C}-\mathrm{C}-\mathrm{I}
$$$$
\text { I- }-c-c-3
$$$$
I-a-c-1
$$$$
\text { I-a-c-i* - } 16
$$$$
I-0-c-1
$$$$
I-a-c-P
$$$$
I-C-C-S
$$$$
0-0-c-8
$$$$
0-0-c-c
$$$$
0-0-c-0
$$$$
0-0-c-5
$$$$
0-0-c-p
$$$$
0-0-c-1
$$$$
0-0-c-j
$$$$
0-0-c-x
$$$$
0-0-c-2
$$$$
0-0-c-1
$$$$
0-0-c-2
$$$$
0-0-c-5
$$$$
-30
$$$$
-110
$$$$
-101-129
$$$$
-62-79
$$$$
-50 \quad-64
$$$$
-36
$$$$
-25
$$$$
-17
$$$$
-31
$$$$
-19
$$$$
-12
$$$$
\begin{aligned}
& -21 \\
& -17
\end{aligned}
$$$$
-7 \quad-10
$$$$
-7
$$$$
-5
$$$$
-3
$$$$
-4
$$$$
256
$$

\section{1}

176

133

78

$-10 \quad 45$

$-10 \quad 21$

$-512$

12
5
5

$$
45
$$$$
17 \text { ast }
$$$$
5212
$$$$
5212
$$$$
\text { smissis }
$$$$
\text { mass }
$$

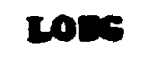

sazen

SIen sIat

$-5194$

$-4023$

$$
-2700
$$

$-1419$

$-641$

$-114$

$$
557
$$

-1 ass

$-1018$

aes

251

$-452-5002$

$-375$

$-276$

$-120$

$-91$

$-127$

11209

7560

$5 x 65$

acas

3659

2000

8sa

17

2126

5381

3481

2302

1325

800

176

$-166$

6

67

$-66$

$-65$

I-0-1)-8 -498

$1-0-1-c \quad 70$

I $-0-1-0$

201

192

$\begin{array}{ll}1-0-1-P \\ 1-0-1-1.7 * & -19\end{array}$

$0-0-1-3 \quad 197$

$0-0-a-c$

$0-0-1-0$

$0-0-1-8$

$0-0-1-P$

$0-0-10-\pi$

$0-0-1-\pi$

$0-0-10-7 *$ *
197

100

190

154

164

161

168

\section{$50 \quad 89$}

$110 \quad 117$

818

2031

- 10

$-5$

207

83

5

$-17$

$-1 ?$

s

$-2$

285

21

5

$-7$

$-5$

(-)

$3602-13857$

9925

3411

1002

$+0$

$-79$

12349

3532

102

$-672$

$-635$

$-73$

$-123$

$14-1761-38572$

3565
7061

6050

475

$-595$

9613

2980

3021

3997

4435

4880

4803

$-6521$
MI SW SSS

\section{$-\infty-0$}

$25 \mathrm{-2}-279-5219$

$205-1300-405$

$222-521-3118$

$190-93-2551$

- $559-1501$

- $4592-1024$

$52 \quad 25 n-\cos 3$

(4) -nov -503

$31-116-379$

$-31-85-21$

$18-115-857$

- $11290 \quad 5330$

-63 750 3400

$\begin{array}{lll}-32 & 5767 \quad 2302\end{array}$

94 asn 1323

$126 \quad 3664$

2000176

$058-170$

$\begin{array}{ll}481 & 3 \\ 212 & \end{array}$

21267

$-66$

$\begin{array}{rrr}-511 & 3617 & -13872 \\ -96 & 9932 & 3558 \\ -32 & 7061 & 3411 \\ -96 & 6052 & 1090 \\ -127 & 4759 & 37 \\ -68 & -71 & -603\end{array}$

$$
\begin{array}{rrr}
32 & 12349 & 9613 \\
32 & 3533 & 2502 \\
1 & 3021 & 102 \\
-126 & 1001 & -676 \\
-158 & 0440 & -670 \\
63 & 4888 & -71 \\
95 & 6005 & -125 \\
23655 & 6026 & -51119
\end{array}
$$


Sable A.t (continued)

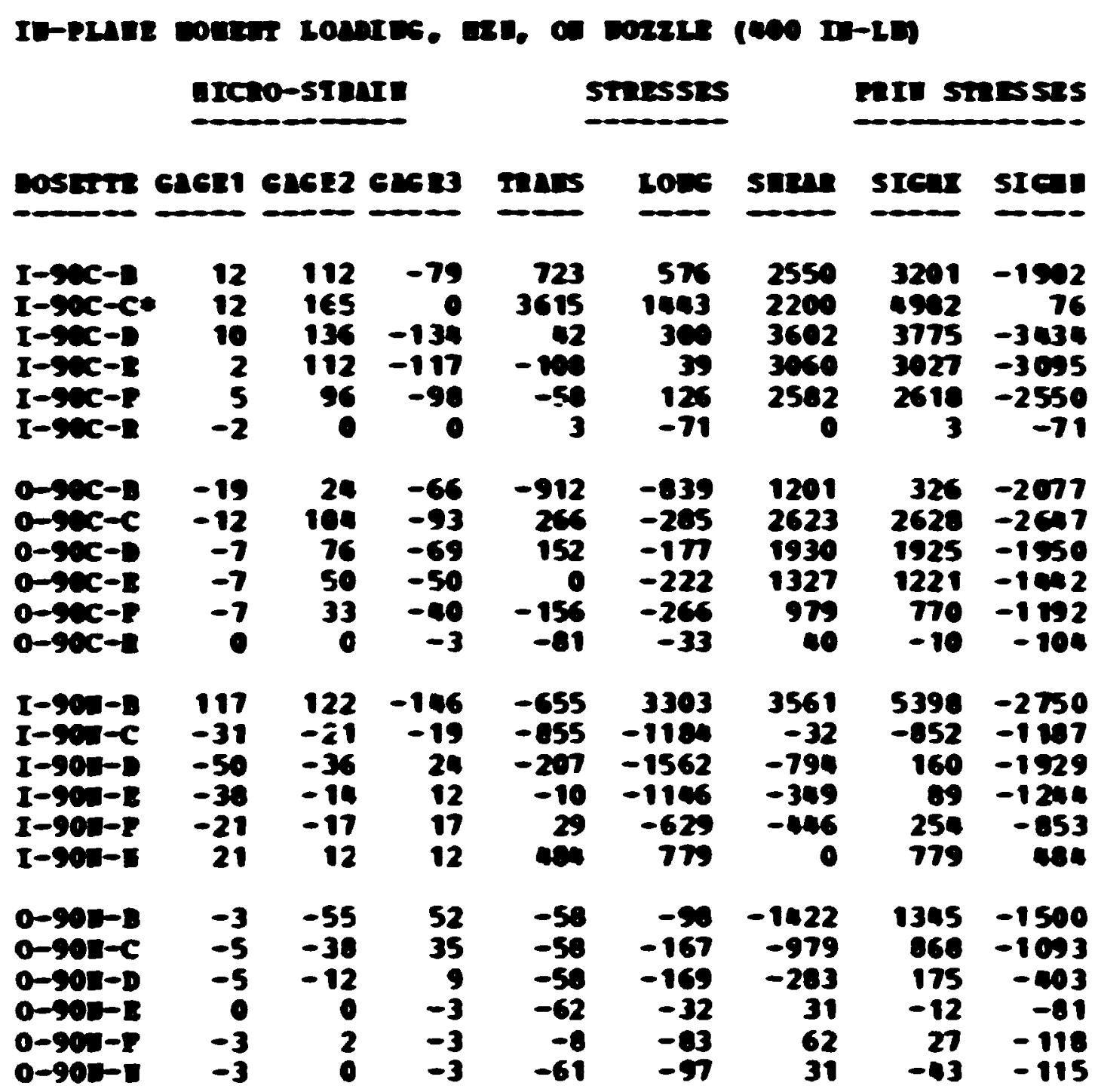




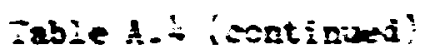

\begin{tabular}{|c|c|c|c|c|c|c|c|c|}
\hline & $a r$ & 0 & & & 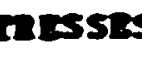 & & ID & \\
\hline & & 54 & & II & & set & & \\
\hline II & $\begin{array}{r}33 \\
21 \\
-2 \\
-21 \\
-28 \\
0\end{array}$ & $\begin{array}{r}108 \\
50 \\
68 \\
58 \\
38 \\
2\end{array}$ & $\begin{array}{r}144 \\
130 \\
94 \\
73 \\
57 \\
2\end{array}$ & $\begin{array}{r}5507 \\
4050 \\
3577 \\
2759 \\
2103 \\
104\end{array}$ & $\begin{array}{r}2642 \\
2145 \\
1002 \\
154 \\
-218 \\
31\end{array}$ & $\begin{array}{r}-471 \\
-471 \\
-345 \\
-283 \\
-251 \\
0\end{array}$ & $\begin{array}{r}5582 \\
1975 \\
3622 \\
2799 \\
2130 \\
104\end{array}$ & $\begin{array}{r}2557 \\
2029 \\
557 \\
154 \\
-244 \\
31\end{array}$ \\
\hline-5 & $\begin{array}{r}-48 \\
-34 \\
-15 \\
0 \\
7 \\
-17\end{array}$ & $\begin{array}{r}-238 \\
-176 \\
-136 \\
-105 \\
-80 \\
-5\end{array}$ & $\begin{array}{r}-248 \\
-165 \\
-126 \\
-95 \\
-78 \\
-5\end{array}$ & $\begin{array}{r}-10624 \\
-7355 \\
-5745 \\
-4103 \\
-3050 \\
-105\end{array}$ & $\begin{array}{r}-1620 \\
-3247 \\
-2164 \\
-1330 \\
-800 \\
-571\end{array}$ & $\begin{array}{r}126 \\
-158 \\
-128 \\
-127 \\
-127 \\
1\end{array}$ & $\begin{array}{r}-1624 \\
-3241 \\
-2159 \\
-1325 \\
-874 \\
-105\end{array}$ & $\begin{array}{l}-10 \\
-7 \\
-5 \\
-4 \\
-3 \\
-\end{array}$ \\
\hline 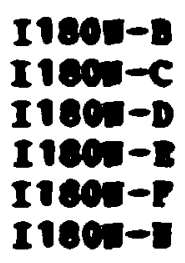 & $\begin{array}{r}149 \\
-26 \\
-191 \\
-203 \\
-172 \\
-129\end{array}$ & $\begin{array}{r}-62 \\
-57 \\
60 \\
-55 \\
-31 \\
-17\end{array}$ & $\begin{array}{r}-131 \\
-150 \\
-60 \\
-2 \\
5 \\
26\end{array}$ & $\begin{array}{r}-4732 \\
-8527 \\
214 \\
-i 030 \\
-301 \\
357\end{array}$ & $\begin{array}{l}12037 \\
-2142 \\
-5657 \\
-6300 \\
-5277 \\
-3757\end{array}$ & $\begin{array}{r}922 \\
1260 \\
1589 \\
-699 \\
-471 \\
-571\end{array}$ & $\begin{array}{r}12080 \\
-1614 \\
617 \\
-941 \\
-335 \\
435\end{array}$ & $\begin{array}{l}-4 \\
-5 \\
-6 \\
-6 \\
-5 \\
-3\end{array}$ \\
\hline & $\begin{array}{r}-143 \\
-62 \\
-119 \\
-162 \\
-164 \\
-178\end{array}$ & $\begin{array}{r}-209 \\
-71 \\
0 \\
7 \\
-5 \\
-9\end{array}$ & $\begin{array}{r}-207 \\
-62 \\
10 \\
10 \\
7 \\
-7\end{array}$ & $\begin{array}{r}-9931 \\
-2857 \\
373 \\
545 \\
233 \\
-165\end{array}$ & $\begin{array}{l}-6371 \\
-2700 \\
-3460 \\
-4683 \\
-4850 \\
-5355\end{array}$ & $\begin{array}{r}-28 \\
-126 \\
-126 \\
-31 \\
-159 \\
-32\end{array}$ & $\begin{array}{r}-6971 \\
-2635 \\
347 \\
545 \\
238 \\
-165\end{array}$ & $\begin{array}{l}-8 \\
-2 \\
-3 \\
-4 \\
-1 \\
-5\end{array}$ \\
\hline
\end{tabular}




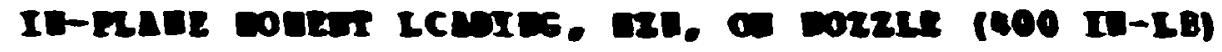

DICo-sIIIT

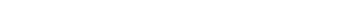

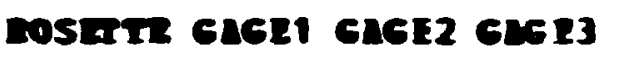

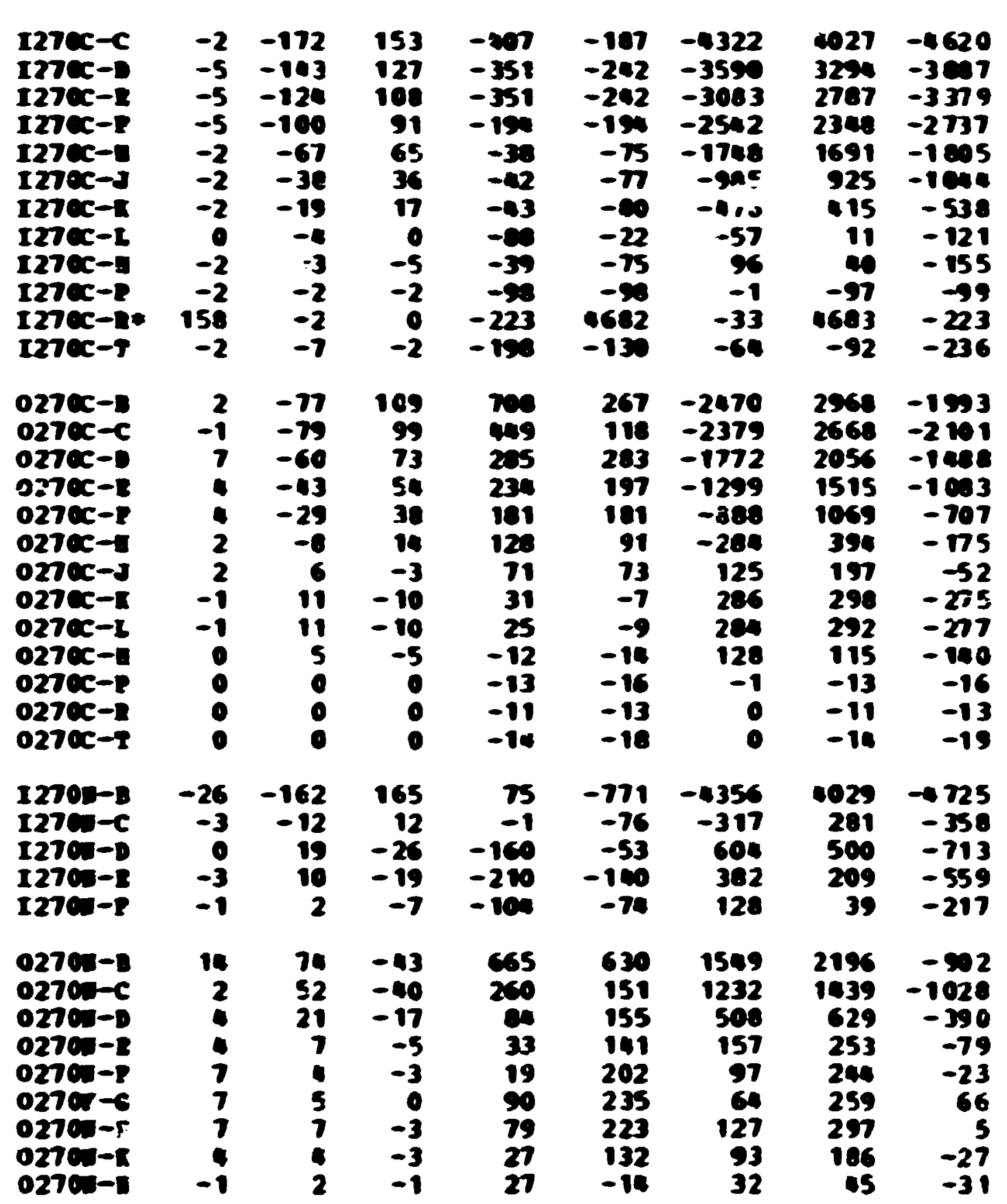

FaI STESTS

\section{-}

mass

rens 
"able A.4 (continuej)

\begin{tabular}{|c|c|c|c|c|c|c|c|c|}
\hline \multirow[b]{2}{*}{ BOSETTE } & \multicolumn{3}{|c|}{ UICBO-STgAIM } & \multicolumn{3}{|c|}{ STRESSES } & \multicolumn{2}{|c|}{ PRIA STRES SES } \\
\hline & GAGEI & GLGE2 & GAGE3 & TR AIS & LOE6 & SBEAR & SIGaX & I Ga \\
\hline 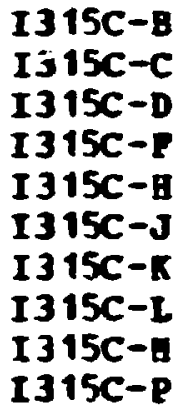 & $\begin{array}{r}-41 \\
-19 \\
0 \\
21 \\
26 \\
28 \\
26 \\
7 \\
0 \\
0\end{array}$ & $\begin{array}{r}-184 \\
-160 \\
-115 \\
-22 \\
0 \\
9 \\
12 \\
0 \\
0 \\
-2\end{array}$ & $\begin{array}{r}-3 \\
31 \\
38 \\
2 \\
21 \\
21 \\
19 \\
7 \\
10 \\
5\end{array}$ & $\begin{array}{r}-4060 \\
-2825 \\
-1695 \\
-457 \\
424 \\
634 \\
639 \\
150 \\
210 \\
53\end{array}$ & $\begin{array}{r}-2440 \\
-1427 \\
-504 \\
498 \\
904 \\
1039 \\
967 \\
260 \\
63 \\
16\end{array}$ & $\begin{array}{r}-2415 \\
-2545 \\
-2038 \\
-318 \\
-285 \\
-159 \\
-96 \\
-96 \\
-127 \\
-96\end{array}$ & $\begin{array}{r}-702 \\
512 \\
1024 \\
594 \\
1037 \\
1094 \\
993 \\
3: 5 \\
284 \\
131\end{array}$ & $\begin{array}{r}-5797 \\
-4765 \\
-3222 \\
-553 \\
291 \\
579 \\
614 \\
95 \\
-11 \\
-63\end{array}$ \\
\hline $\begin{array}{l}:-B \\
:-C \\
:-D \\
: \cdots \\
:-7 \\
:-1 \\
:-K \\
--1 \\
--1 \\
:-P\end{array}$ & $\begin{array}{r}40 \\
40 \\
28 \\
14 \\
9 \\
-3 \\
-7 \\
0 \\
-3 \\
-3\end{array}$ & $\begin{array}{r}85 \\
64 \\
59 \\
47 \\
38 \\
16 \\
-10 \\
-15 \\
-10 \\
-5\end{array}$ & $\begin{array}{l}140 \\
116 \\
117 \\
83 \\
62 \\
23 \\
-7 \\
-7 \\
-7 \\
-5\end{array}$ & $\begin{array}{r}4897 \\
3907 \\
3715 \\
2043 \\
2771 \\
879 \\
-366 \\
-487 \\
-370 \\
-217\end{array}$ & $\begin{array}{r}2 E 70 \\
2375 \\
1962 \\
1277 \\
930 \\
183 \\
-331 \\
-154 \\
-188 \\
-143\end{array}$ & $\begin{array}{r}-727 \\
-694 \\
-696 \\
-474 \\
-317 \\
-95 \\
-31 \\
-94 \\
-33 \\
-1\end{array}$ & $\begin{array}{r}5113 \\
4174 \\
3957 \\
2976 \\
2248 \\
892 \\
-313 \\
-128 \\
-182 \\
-143\end{array}$ & $\begin{array}{r}2454 \\
2107 \\
1719 \\
1144 \\
853 \\
171 \\
-383 \\
-507 \\
-376 \\
-217\end{array}$ \\
\hline 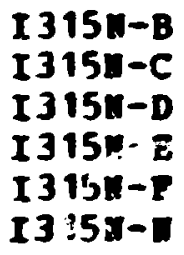 & $\begin{array}{r}-308 \\
60 \\
139 \\
124 \\
105 \\
97\end{array}$ & $\begin{array}{r}-100 \\
55 \\
60 \\
19 \\
0 \\
-9\end{array}$ & $\begin{array}{r}122 \\
86 \\
43 \\
14 \\
7 \\
-5\end{array}$ & $\begin{array}{r}811 \\
3034 \\
2107 \\
599 \\
42 \\
-417\end{array}$ & $\begin{array}{r}-9008 \\
2703 \\
4792 \\
3909 \\
3168 \\
2774\end{array}$ & $\begin{array}{r}-2962 \\
-414 \\
223 \\
64 \\
-96 \\
-63\end{array}$ & $\begin{array}{l}1636 \\
3315 \\
4810 \\
3910 \\
3171 \\
2776\end{array}$ & $\begin{array}{r}-9833 \\
2423 \\
2088 \\
598 \\
39 \\
-418\end{array}$ \\
\hline $\begin{array}{l}0315 \\
0315 \\
0315 \\
0315 \\
0315 \\
0315 \\
0315 \\
0315 \\
0315\end{array}$ & $\begin{array}{r}201 \\
52 \\
64 \\
92 \\
111 \\
123 \\
118 \\
123 \\
-30\end{array}$ & $\begin{array}{r}268 \\
1: 8 \\
26 \\
-2 \\
-4 \\
3 \\
3 \\
3 \\
3\end{array}$ & $\begin{array}{r}197 \\
40 \\
-4 \\
-9 \\
-6 \\
1 \\
3 \\
6 \\
6\end{array}$ & $\begin{array}{r}9990 \\
3429 \\
421 \\
-349 \\
-347 \\
-43 \\
-2 \\
58 \\
226\end{array}$ & $\begin{array}{l}9014 \\
2588 \\
2049 \\
2659 \\
3237 \\
3678 \\
3547 \\
3703 \\
-821\end{array}$ & $\begin{array}{r}946 \\
1042 \\
398 \\
86 \\
34 \\
36 \\
-1 \\
-35 \\
-32\end{array}$ & $\begin{array}{r}10567 \\
4132 \\
2141 \\
2661 \\
3237 \\
3678 \\
3547 \\
3703 \\
227\end{array}$ & $\begin{array}{r}8437 \\
1885 \\
329 \\
-351 \\
-348 \\
-44 \\
-2 \\
58 \\
-822\end{array}$ \\
\hline
\end{tabular}




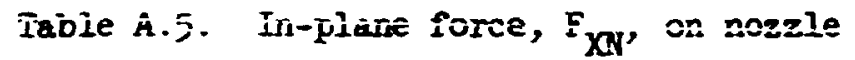

IN-PLANE PORCE loATIMg, PXM, ON MOZZLE (80 LB)

HICRO-STERTH

- -$$
\text { sosent }
$$

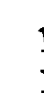

$\mathbf{I}$

$\mathbf{I}$

$$
\mathbf{I}-0
$$

$$
\mathbf{I}
$$

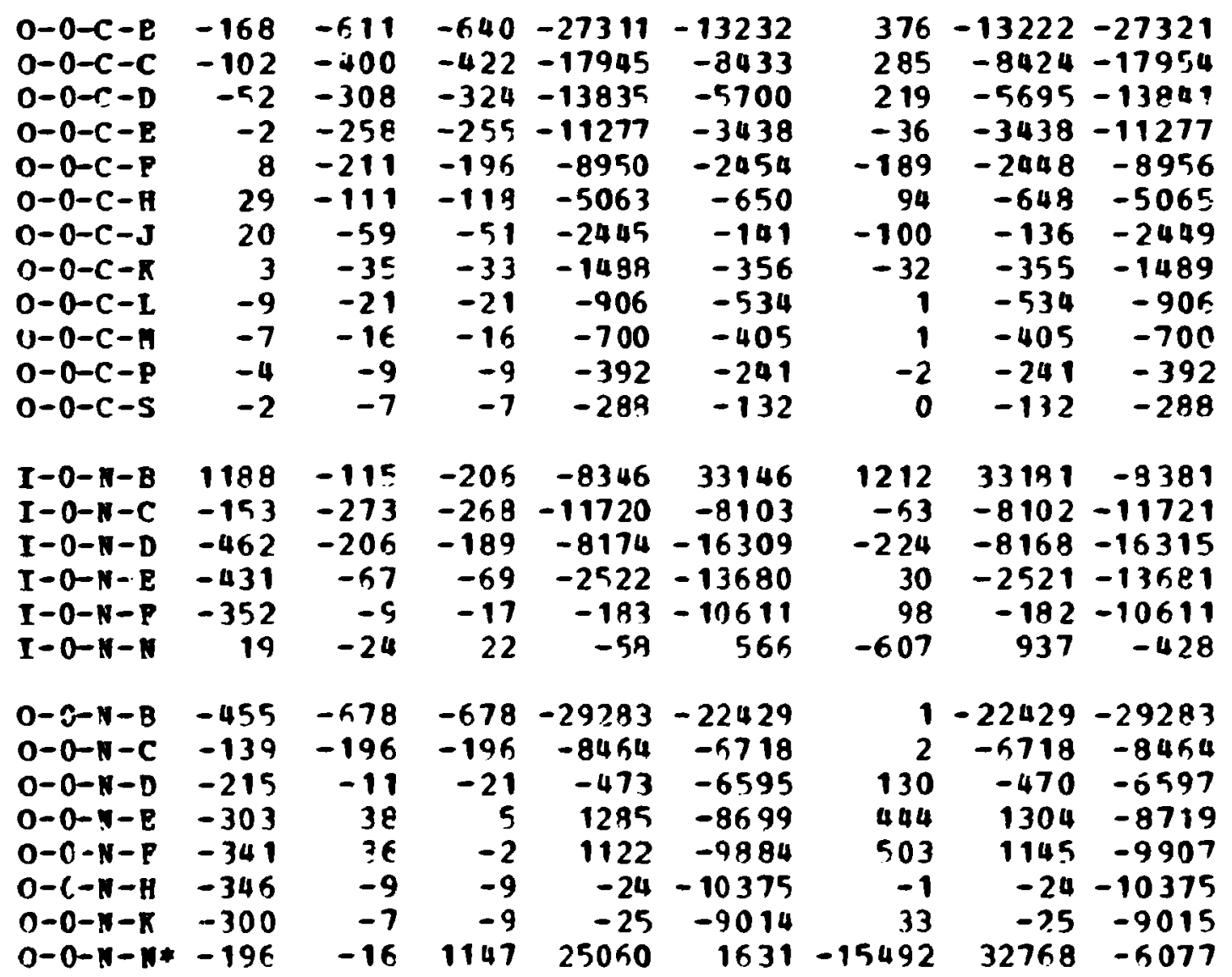

\section{STRESSES}

\section{PRIM STRESSES}

AGF1 GAGE 2 GAGE 3

TRANS

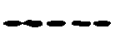

$1-0-c-c$

$1-0-c-0$

$-0-c-E$

$-0-C-P$

$-71$

$1-0-c+c$

$-0-c-p$

$-0-c-5$ 
Table A.5 (continuej)

In-PLAne PORCE LOACTMg, FTA, OA YOZZLE (80 LB)

MTCRO-STRATE

-

ROSETTE GAGF 1 GAGF 2 GAGE3$$
-
$$$$
\begin{array}{lrr}
I-90 C-B & -26 & -242 \\
I-90 C-C * & -24 & -364 \\
I-90 C-D & -17 & -304 \\
I-9 n C-E & -5 & -256 \\
I-90 C-F & -12 & -180 \\
I-90 C-R * & 0 & 0
\end{array}
$$$$
201
$$$$
201
$$$$
323
$$$$
275
$$$$
230
$$$$
\text { C }
$$

$\begin{array}{lll}0-90 C-B \quad 34 & -87\end{array}$

$0-90 C-C \quad 22-258$

$0-90 C-D \quad 15-192$

$0-90 C-E$

$\begin{array}{rr}10 & -132 \\ 5 & -85\end{array}$

$0-90 C-F$

$0-90 C-R$

11

124

207

$15 \mathrm{C}$

107

83

6

$\begin{array}{rrr}I-90 N-B & -224 & -267 \\ I-90 N-C & 64 & 57 \\ I-90 N-D & 96 & 91 \\ I-90 N-E & 70 & 48 \\ I-90 N-P & 48 & 41 \\ I-90 N-I & -54 & -21\end{array}$

332

10

$-50$

$-60$

$-45$

$-33$

$-86$

\section{STRESSES \\ -......}

PRIN STRESSES

TRANS

LONG

SHEAR

SIGHX SIGAN

---

-.--

- - -

-.o- -.--

$-7970$

$-1048 \quad-5901$

$4946-6898$

$-115-10962$

$8404-8331$

$7293-6877$

428

$\begin{array}{ll}-369 & -8397\end{array}$

$-12-7081$

$\begin{array}{rrr}1110 & -24 & -5461 \\ 3 & 3 & 0\end{array}$

$6033-4947$

771
-1156
-928
-569
-43
156

$1248-2806$

$309-6195$

$165-4558$

$129-3192$

$140-2244$

$63-78$

1658

1399

$-6211$

$-7981$

2354

635

$580 \quad 3049$

2004

1431

1144

$-154$

$-1116$

1389

159

$0-90 n-B \quad-16$

$0-90 N-C$

$0-90 n-n$

$0-90 n-8$

$0-90 \mathrm{~N}-\mathrm{i}$

$0-90 N-n$

3

$79-137$

62

137

$-1270$

$-1963$

2877

-862
-5

$-2$

$-295$

72

$\begin{array}{ll}\cdots & -21\end{array}$

$-66-13$

$-2$

$-18$

15

$-122$

142

13

$-122$

$-212$

$-144$

1832

93

$-474$

$-439$

$-410$

$\begin{array}{rr}3826 & -1907 \\ 5815 & -6662 \\ 4210 & -4972 \\ 2991 & -3431 \\ 2294 & -2197 \\ 200 & 18\end{array}$

$5627-11174$

$2671 \quad 1082$

$4168-539$

$2668-1017$

$1997-762$

$\begin{array}{ll}-1097-1992 & -1997\end{array}$

$\begin{array}{rr}1818 & -3950 \\ 1688 & -1988 \\ 150 & -39 \\ 309 & -642 \\ 461 & -463 \\ 306 & -515\end{array}$ 
In-PLANE PORCE LOATING, FXA, OH NOZZLE (BO LB)

\begin{tabular}{|c|c|c|c|c|c|c|c|c|}
\hline & \multicolumn{3}{|c|}{ HTCPO-ST FAIH } & \multicolumn{3}{|c|}{ STRPSSES } & \multicolumn{2}{|c|}{ PRIA STRESSES } \\
\hline SET TE & GAGE1 & GAGE 2 & GAGE3 & CRAIS & LONG & GEAR & STGAX & SIGA \\
\hline & & & & & & & -- & \\
\hline $\begin{array}{l}-B \\
-C \\
-D \\
-B \\
-P \\
-C\end{array}$ & $\begin{array}{r}-75 \\
-52 \\
9 \\
50 \\
66 \\
2\end{array}$ & $\begin{array}{r}-252 \\
-231 \\
-170 \\
-127 \\
-94 \\
-5\end{array}$ & $\begin{array}{r}-316 \\
-285 \\
-209 \\
-163 \\
-127 \\
-5\end{array}$ & $\begin{array}{r}-12 \\
-11 \\
-8 \\
-6 \\
-4 \\
-\end{array}$ & $\begin{array}{r}-5987 \\
-4929 \\
-2207 \\
-442 \\
498 \\
11\end{array}$ & $\begin{array}{l}89 \\
92 \\
03 \\
71 \\
40 \\
0\end{array}$ & $\begin{array}{r}-5,877 \\
-4857 \\
-2165 \\
-405 \\
533 \\
11\end{array}$ & $\begin{array}{r}-12 \\
-11 \\
-8 \\
-6 \\
-4 \\
-\end{array}$ \\
\hline $\begin{array}{l}\text { B } \\
\text { C } \\
\text { D } \\
\text { E } \\
\text { P } \\
\text { S }\end{array}$ & $\begin{array}{r}115 \\
84 \\
44 \\
8 \\
-17 \\
-32\end{array}$ & $\begin{array}{r}540 \\
405 \\
305 \\
241 \\
195 \\
0\end{array}$ & $\begin{array}{r}526 \\
386 \\
300 \\
224 \\
176 \\
0\end{array}$ & $\begin{array}{r}23297 \\
17275 \\
13339 \\
10196 \\
8173 \\
38\end{array}$ & $\begin{array}{r}10433 \\
7702 \\
5311 \\
3293 \\
1955 \\
-951\end{array}$ & $\begin{array}{r}192 \\
251 \\
129 \\
222 \\
253 \\
1\end{array}$ & $\begin{array}{r}23300 \\
17282 \\
13340 \\
10203 \\
8134 \\
38\end{array}$ & $\begin{array}{r}10 \\
7 \\
5 \\
3 \\
1 \\
-\end{array}$ \\
\hline $\begin{array}{l}-B \\
-C \\
-D \\
-E \\
-P\end{array}$ & $\begin{array}{r}-1039 \\
51 \\
432 \\
451 \\
380 \\
144\end{array}$ & $\begin{array}{r}120 \\
12 C \\
-152 \\
113 \\
57 \\
20\end{array}$ & $\begin{array}{r}311 \\
344 \\
129 \\
-4 \\
-9\end{array}$ & $\begin{array}{r}10507 \\
10137 \\
-970 \\
1890 \\
620 \\
-438\end{array}$ & $\begin{array}{r}27982 \\
4561 \\
12676 \\
14105 \\
11578 \\
4179\end{array}$ & $\begin{array}{r}-29 \\
-37 \\
15 \\
8 \\
7\end{array}$ & $\begin{array}{l}10773 \\
11434 \\
13637 \\
14301 \\
11649 \\
4283\end{array}$ & $\begin{array}{r}32 \\
-15 \\
15 \\
5 \\
-5\end{array}$ \\
\hline $\begin{array}{l}0180 N-B \\
0180 N-C \\
0180 N-D \\
0180 N-B \\
0180 \pi-P \\
0180 N-N\end{array}$ & $\begin{array}{l}328 \\
128 \\
250 \\
345 \\
347\end{array}$ & $\begin{array}{r}171 \\
-12 \\
14 \\
5\end{array}$ & $\begin{array}{r}468 \\
138 \\
-31 \\
-31 \\
-26 \\
0\end{array}$ & $\begin{array}{r}20925 \\
6555 \\
-847 \\
-1318 \\
-642 \\
-115\end{array}$ & $\begin{array}{r}58 \\
72 \\
99 \\
102 \\
60\end{array}$ & $\begin{array}{r}422 \\
444 \\
475 \\
254 \\
539 \\
63\end{array}$ & $\begin{array}{r}72 \\
99 \\
102 \\
60\end{array}$ & $\begin{array}{c}5 \\
-1 \\
-1 \\
- \\
-\end{array}$ \\
\hline
\end{tabular}


Table A. 5 (continued)

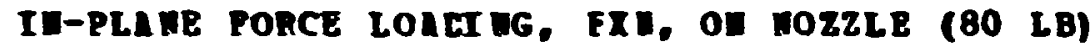

nICEO-STEATa

$-0-0$
ST RESSES
PRI STRESES

-

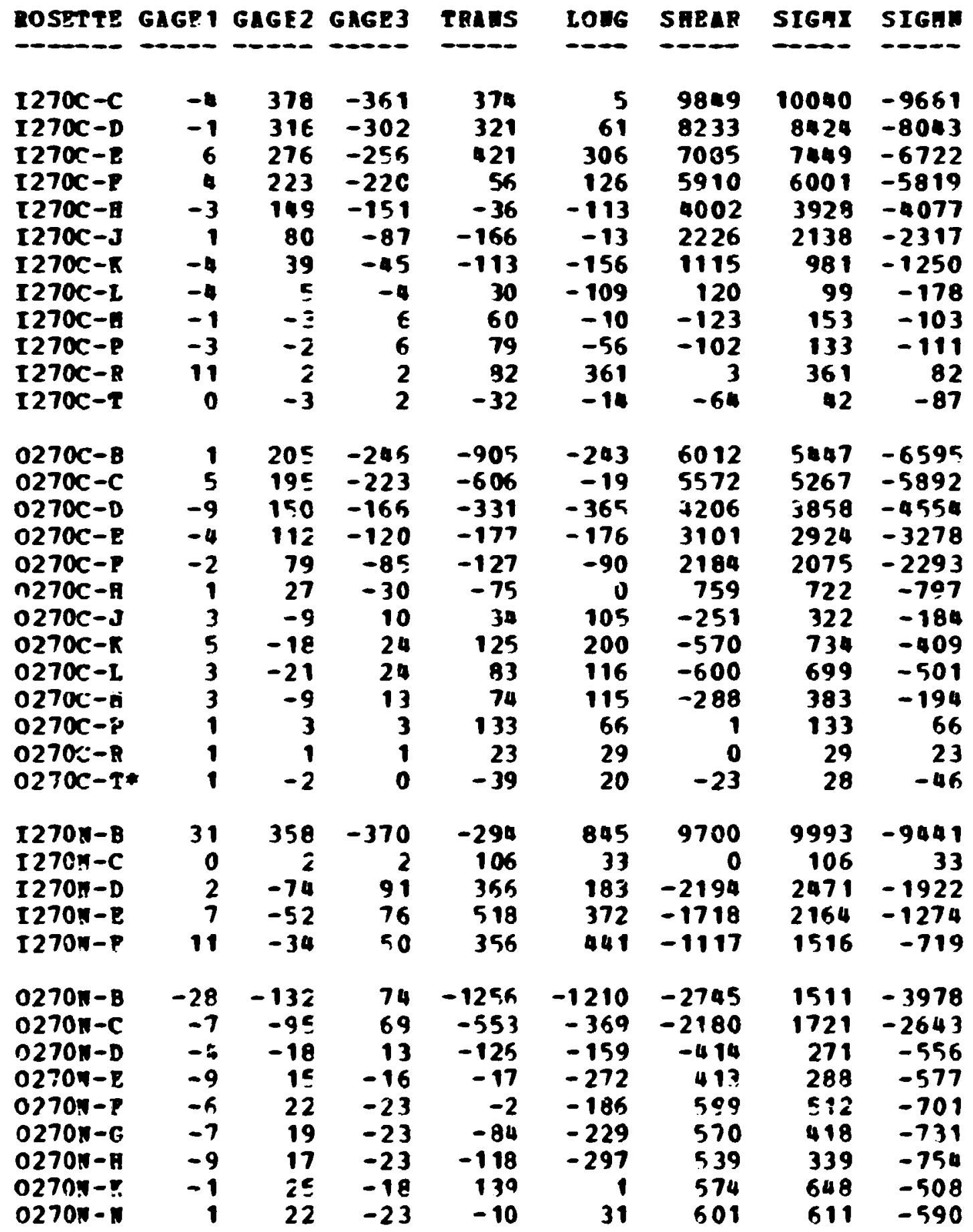


Teble A.S (continied)

In-PLANE FORCE LOACTEG, FIB, ON FOZZLE (80 LB)

aICRO-STRLIn

$-\infty-\infty-\infty$

rOSETTE GLGEI GLGE2 GIGE3

$-$

$1315 \mathrm{C}-$

$1315 C-C$

I315C-D

$1315 C-P$

$1315 C-8$

I315C-j

$1315 C-\pi$

I $315 C-$ I

$1315 \mathrm{C}-\mathrm{n}$

I315C-P

$0315 C-B$

$0315 C-C$

$0315 C-D$

$0315 C-E$

$0315 \mathrm{C}-\mathrm{F}$

$0315 \mathrm{C}-\mathrm{H}$

$0315 c-k$

$0315 \mathrm{C}-\mathrm{2}$

$0315 C-n$

$0315 C-P$

\begin{tabular}{|c|c|}
\hline $\begin{array}{l}\text { I3 15n-B } \\
\text { I } 315 \pi-C \\
\text { I3 } 15 \pi-D \\
\text { I3 15n-E } \\
\text { I3 15N-P } \\
\text { I3 15n-N }\end{array}$ & $\begin{array}{r}715 \\
-134 \\
-313 \\
-273 \\
-225 \\
-106\end{array}$ \\
\hline $\begin{array}{l}0315 n-B \\
0315 n-C \\
0315 n-D \\
0315 n-E \\
0315 n-F \\
0315 n-G \\
0315 n-A \\
0315 n-R \\
0315 n-R\end{array}$ & $\begin{array}{l}-456 \\
-106 \\
-130 \\
-188 \\
-231 \\
-250 \\
-240 \\
-219 \\
-53\end{array}$ \\
\hline
\end{tabular}

$-94$

$-89$

$-63$

$-18$

12

15

3

5

$$
\begin{array}{r}
-196 \\
-142 \\
-125 \\
-97 \\
-77 \\
-38 \\
26 \\
19 \\
19 \\
8
\end{array}
$$

$-142$

$-38$

26

19

$$
\begin{array}{r}
-612 \\
-258 \\
-42 \\
28 \\
28 \\
13 \\
14
\end{array}
$$

18

\section{STRESSES}

TRIIS

LODG

9154

6326

3717

925

$-1155$

$-1726$

$-164$

$-453$

$-788$

$-262$

5588

3200

1036

$-1353$

$-2261$

$-2718$

$-2260$

$-711$

$-289$

$-75$

$$
\begin{array}{rr}
227 & -273 \\
-155 & -175 \\
-167 & -69 \\
-72 & -7 \\
-24 & 10 \\
-7 & 28
\end{array}
$$

$$
\begin{array}{rrr}
-334 & -11594 & -6286 \\
-274 & -9047 & -5399 \\
-258 & -8355 & -4409 \\
-189 & -6249 & -2861 \\
-140 & -4743 & -1975 \\
-54 & -2029 & -236 \\
17 & 938 & 722 \\
17 & 801 & 329 \\
12 & 693 & 218 \\
5 & 275 & 238
\end{array}
$$

$-178$

$-7106$

$-4858$

$-1433$

-67
584

20923

$-6150$

$-10858$

$-8609$

$-6765$

$-3003$

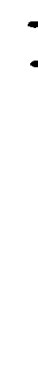$$
\begin{array}{r}
-48 \\
-116 \\
- \\
-10 \\
-22 \\
-2 \\
-29 \\
-26
\end{array}
$$

$-486-2$

$-23623-20766$

$-8108-5628$
-960

$-\mathrm{e}$

$-960$

870

$-562$

$-10$

643

$-5385$

$-22$

91
-11

$-11$

$11-7205$

$-29$

$-17$
SAEAR

5722

6076

4847

763

762

414

223

348

274

157

$$
1834
$$

1766

177

1233

831

221

125

31

97

34

6561
255

$-1307$

$-860$

$-446$

$-471$

$-1672$

$-189$

$-463$

349

499

466

533

628

563
PRIA STRESSES

- -
SIGRX SIGA

$13350 \quad 1352$

$11037-1511$

$7405-2652$

$1157-1585$

$-757-2649$

$-1576-2868$

$\begin{array}{ll}-1559 & -2332\end{array}$

$-211-953$

$-98-580$

$14-351$

$-5709-12121$

$-4684-9762$

$\begin{array}{lll}-3731 & -9033\end{array}$

$-2460-6650$

$-1744-4974$

$-209-2055$

$995 \quad 665$

$803 \quad 327$

$712 \quad 199$

$296 \quad 218$

$22733-3594$

$-5086-7170$

$-4595-11130$

$\begin{array}{ll}-1332 & -8711\end{array}$

$-37-6795$

$645-3060$

$-19996-24393$

$-4601-9131$

$-894-4241$

$890-5404$

$677-5764$

$120-7587$

$28-7244$

$67-6523$

$17-1826$ 
Table A.6. Axial force, $F_{Y N}$, on nozzle

AIIAL PCRCE LOADIUG, PYW, CG WOZZLE (400 LB)

\begin{tabular}{|c|c|c|c|c|c|c|c|c|}
\hline \multirow[b]{2}{*}{ OSETTE } & \multicolumn{3}{|c|}{ AICRO-STRAII } & \multicolumn{3}{|c|}{ STRESSES } & \multicolumn{2}{|c|}{ PR IN STRES SES } \\
\hline & & & & pare & LOIG & $\mathbf{E} \mathbf{A R}$ & GKX & $516 n$ \\
\hline 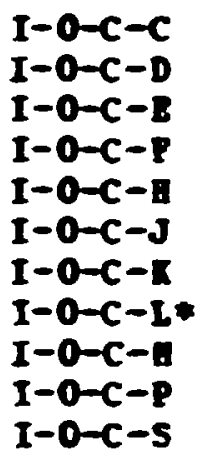 & $\begin{array}{r}-15 \\
24 \\
43 \\
50 \\
54 \\
40 \\
28 \\
69 \\
9 \\
2 \\
2\end{array}$ & $\begin{array}{l}-50 \\
-58 \\
-60 \\
-67 \\
-93 \\
-81 \\
-53 \\
-61 \\
-36 \\
-27 \\
-15\end{array}$ & $\begin{array}{r}-115 \\
-117 \\
-110 \\
-110 \\
-72 \\
-62 \\
-76 \\
-58 \\
-46 \\
-29 \\
-14\end{array}$ & $\begin{array}{r}-3616 \\
-3865 \\
-3782 \\
-3943 \\
-3690 \\
-3206 \\
-2827 \\
-2245 \\
-1808 \\
-1232 \\
-632\end{array}$ & $\begin{array}{r}-1523 \\
-452 \\
148 \\
311 \\
526 \\
243 \\
-2 \\
1409 \\
-268 \\
-311 \\
-138\end{array}$ & $\begin{array}{r}858 \\
794 \\
667 \\
573 \\
-286 \\
-253 \\
289 \\
223 \\
126 \\
34 \\
-14\end{array}$ & $\begin{array}{r}-1216 \\
-276 \\
258 \\
387 \\
546 \\
261 \\
28 \\
1423 \\
-258 \\
-310 \\
-137\end{array}$ & $\begin{array}{r}-3923 \\
-4041 \\
-3892 \\
-4019 \\
-3710 \\
-3225 \\
-2857 \\
-2258 \\
-1818 \\
-1233 \\
-633\end{array}$ \\
\hline $\begin{array}{l}-B \\
-C \\
-D \\
-2 \\
-P \\
-B \\
-J \\
-1 \\
-2 \\
-1 \\
-P \\
-5\end{array}$ & $\begin{array}{r}52 \\
26 \\
14 \\
-3 \\
-1 \\
-3 \\
2 \\
7 \\
7 \\
4 \\
0 \\
-5\end{array}$ & $\begin{array}{l}269 \\
163 \\
137 \\
125 \\
113 \\
78 \\
66 \\
52 \\
12 \\
35 \\
26 \\
14\end{array}$ & $\begin{array}{l}194 \\
142 \\
123 \\
106 \\
92 \\
75 \\
54 \\
47 \\
38 \\
31 \\
23 \\
14\end{array}$ & $\begin{array}{r}8792 \\
6676 \\
5702 \\
5086 \\
4518 \\
3370 \\
2644 \\
2170 \\
1755 \\
1444 \\
1086 \\
621\end{array}$ & $\begin{array}{r}4193 \\
2778 \\
2124 \\
1441 \\
1339 \\
926 \\
854 \\
856 \\
730 \\
567 \\
317 \\
33\end{array}$ & $\begin{array}{r}192 \\
284 \\
191 \\
257 \\
284 \\
32 \\
160 \\
63 \\
63 \\
63 \\
32 \\
0\end{array}$ & $\begin{array}{r}8800 \\
6696 \\
5712 \\
5104 \\
4543 \\
3371 \\
2659 \\
2173 \\
1759 \\
1449 \\
1087 \\
621\end{array}$ & $\begin{array}{l}4185 \\
2757 \\
2114 \\
1423 \\
1314 \\
926 \\
840 \\
853 \\
726 \\
563 \\
316 \\
32\end{array}$ \\
\hline $\begin{array}{l}-B \\
-C \\
-D \\
-E \\
-P \\
-D\end{array}$ & $\begin{array}{r}-386 \\
7 \\
98 \\
81 \\
57 \\
62\end{array}$ & $\begin{array}{r}103 \\
117 \\
77 \\
33 \\
17 \\
7\end{array}$ & $\begin{array}{r}31 \\
105 \\
81 \\
36 \\
17 \\
-3\end{array}$ & $\begin{array}{r}3360 \\
4879 \\
3362 \\
1432 \\
666 \\
24\end{array}$ & $\begin{array}{r}-10564 \\
1670 \\
3945 \\
2864 \\
1918 \\
1867\end{array}$ & $\begin{array}{r}957 \\
159 \\
-63 \\
-30 \\
-2 \\
128\end{array}$ & $\begin{array}{l}3425 \\
4887 \\
3951 \\
2864 \\
1918 \\
1876\end{array}$ & $\begin{array}{r}-1062 \\
166 \\
335 \\
143 \\
66\end{array}$ \\
\hline $\begin{array}{l}-\mathbf{Z} \\
-\mathbf{X} \\
-\mathbf{I}\end{array}$ & $\begin{array}{r}21 \\
-60 \\
-24 \\
14 \\
31 \\
42 \\
54 \\
57\end{array}$ & $\begin{array}{r}168 \\
26 \\
-26 \\
-29 \\
-24 \\
-17 \\
-14 \\
0\end{array}$ & $\begin{array}{r}187 \\
45 \\
-14 \\
-21 \\
-14 \\
-10 \\
-7 \\
77\end{array}$ & $\begin{array}{r}7785 \\
1615 \\
-868 \\
-1116 \\
-875 \\
-625 \\
-532 \\
1632\end{array}$ & $\begin{array}{r}2971 \\
-1302 \\
-979 \\
85 \\
654 \\
1087 \\
1466 \\
2191\end{array}$ & $\begin{array}{r}-253 \\
-254 \\
-159 \\
-96 \\
-125 \\
-94 \\
-95 \\
-1033\end{array}$ & $\begin{array}{r}7799 \\
1637 \\
-755 \\
93 \\
665 \\
1092 \\
1471 \\
2982\end{array}$ & $\begin{array}{r}29 \\
-13 \\
-10 \\
-11 \\
-8 \\
-6 \\
-5\end{array}$ \\
\hline
\end{tabular}




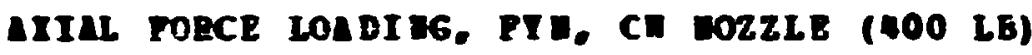

QTCRO-STRATU

$-00-0-0$

POSITTE GAGEI GAGE2 GAGE3 TRAHS

$I-90 \mathrm{C}-\mathrm{B}$

$2-20-3-1,-17$

$\mathrm{I}-90 \mathrm{C}-\mathrm{D}$

$I-900-$

$I-90 C-P$

I-900-2

$0-906-8$

$0-90 \mathrm{C}-\mathrm{C}$

$0-90 C-D$

$0-900-2$

$0-900-5$

$0-90 C-8$

$I-901-$

$I-901-C$

I-90I-D

I-901-

I-90I-P*

I-901-

0-907-B

0-90I-C

0-901-D

0-901-E

0-901-?

$0-901-1$

$-2190$

$-2$

$-10$

$-10$

$-710$

$-276$

121

119

142

5731

5129

4041

1979

$-604$

$-14$

$-14$

$-10$

1791

451608

$-250$

$-36$

$-1432$

$206 \quad 8570$

6 i

2364

12

126
580

$\begin{array}{rrrr}45 & 17 & 12 & 580 \\ 29 & -5 & 7 & 25\end{array}$
STRESSES

PRII STERSES

Long

SaER

?

$-1159$

$-552$

$-95$

505

1025

276

2595

2777

2539

2070

1209

738

$-462$

0
-542
127
96
319
96

$-1159-2190$

$-151-1284$

$-81-1286$

$\begin{array}{ll}512 & -717\end{array}$

$1122-28$

$292-292$

32

126

64

63

$-3$

5759

5129

4049

2597

1982

$-462$

2749

2538

2062

1206

735

$-604$

$-8343$

2735

3767

1145

128

$-150$

$-223$

2423

$-2372$

$-1725$

$-1079$

64

1919

3212

3779

2442

28

$-1419$

4995

356

$-253$

858

2403

702

631

$-285$

$-190$

$-158$

64

1530

$-158$

997

$-8470$

2701

1596

$-268$

893

-2857
-1738

4977

316

121

98

576

865

$-3$ 
Table A.6 (continued)

AIIAL FORCE LONDING. PYH. CA DOZ2LE (400 LB)

\begin{tabular}{|c|c|c|c|c|c|c|c|c|}
\hline \multirow[b]{2}{*}{ ROSETTE } & \multicolumn{3}{|c|}{ AICRO-STELIE } & \multicolumn{3}{|c|}{ STERSSES } & \multicolumn{2}{|c|}{ PRIE STRES SES } \\
\hline & & 1652 & & RAIS & 10.6 & SAELR & SIGnX & STE \\
\hline $\begin{array}{l}I 180 C-B \\
I 180 C-C \\
\text { I } 180 C-D \\
\text { I } 180 C-E \\
\text { I } 180 C-F \\
\text { I } 180 C-S\end{array}$ & $\begin{array}{r}-7 \\
7 \\
33 \\
52 \\
52 \\
-1\end{array}$ & $\begin{array}{r}-76 \\
-104 \\
-102 \\
-102 \\
-90 \\
-22\end{array}$ & $\begin{array}{l}-31 \\
-50 \\
-62 \\
-69 \\
-73 \\
-24\end{array}$ & $\begin{array}{l}-2335 \\
-3388 \\
-3624 \\
-3801 \\
-3643 \\
-1008\end{array}$ & $\begin{array}{r}-920 \\
-812 \\
-110 \\
407 \\
456 \\
-322\end{array}$ & $\begin{array}{r}-598 \\
-724 \\
-534 \\
-439 \\
-220 \\
31\end{array}$ & $\begin{array}{r}-701 \\
-622 \\
-30 \\
452 \\
468 \\
-320\end{array}$ & $\begin{array}{l}-2554 \\
-3577 \\
-3703 \\
-3846 \\
-3654 \\
-1009\end{array}$ \\
\hline $\begin{array}{l}0180 C-B \\
0180 C-C \\
0180 C-D \\
0180 C-E \\
0180 C-F \\
0180 C-S\end{array}$ & $\begin{array}{r}35 \\
21 \\
9 \\
-1 \\
-7 \\
33\end{array}$ & $\begin{array}{r}142 \\
119 \\
107 \\
92 \\
86 \\
17\end{array}$ & $\begin{array}{r}190 \\
154 \\
133 \\
112 \\
95 \\
19\end{array}$ & $\begin{array}{r}7268 \\
5973 \\
5262 \\
4485 \\
3979 \\
747\end{array}$ & $\begin{array}{r}3237 \\
2417 \\
1846 \\
1330 \\
980 \\
1223\end{array}$ & $\begin{array}{r}-636 \\
-473 \\
-350 \\
-254 \\
-127 \\
-32\end{array}$ & $\begin{array}{l}7366 \\
6035 \\
5298 \\
4505 \\
3984 \\
1225\end{array}$ & $\begin{array}{l}3139 \\
2355 \\
1810 \\
1310 \\
974 \\
745\end{array}$ \\
\hline 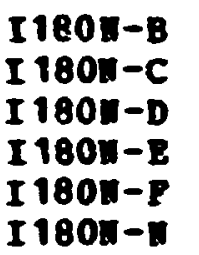 & $\begin{array}{r}-287 \\
-31 \\
64 \\
62 \\
37 \\
36\end{array}$ & $\begin{array}{r}0 \\
38 \\
-41 \\
43 \\
28 \\
12\end{array}$ & $\begin{array}{r}117 \\
126 \\
62 \\
26 \\
9 \\
-12\end{array}$ & $\begin{array}{r}2867 \\
3638 \\
389 \\
1439 \\
778 \\
-55\end{array}$ & $\begin{array}{r}-7735 \\
154 \\
2039 \\
2284 \\
1357 \\
1049\end{array}$ & $\begin{array}{r}-1559 \\
-1176 \\
-1367 \\
221 \\
250 \\
316\end{array}$ & $\begin{array}{l}3091 \\
3998 \\
2811 \\
2338 \\
1450 \\
1133\end{array}$ & $\begin{array}{r}-7960 \\
-206 \\
-383 \\
1385 \\
685 \\
-139\end{array}$ \\
\hline $\begin{array}{l}0180 \pi-E \\
01801-C \\
0180 \pi-D \\
0180 \pi-E \\
01804-P \\
01808-Z\end{array}$ & $\begin{array}{r}-26 \\
-71 \\
-26 \\
7 \\
19 \\
50\end{array}$ & $\begin{array}{r}115 \\
21 \\
-31 \\
-31 \\
-24 \\
-5\end{array}$ & $\begin{array}{r}124 \\
21 \\
-17 \\
-17 \\
-14 \\
2\end{array}$ & $\begin{array}{r}5273 \\
1019 \\
-1016 \\
-1053 \\
-857 \\
-107\end{array}$ & $\begin{array}{r}798 \\
-1834 \\
-1089 \\
-102 \\
314 \\
1466\end{array}$ & $\begin{array}{r}-113 \\
0 \\
-190 \\
-190 \\
-127 \\
-95\end{array}$ & $\begin{array}{r}5276 \\
1019 \\
-859 \\
-65 \\
327 \\
1471\end{array}$ & $\begin{array}{r}795 \\
-1834 \\
-1246 \\
-1089 \\
-870 \\
-113\end{array}$ \\
\hline
\end{tabular}


Eabie s.6 lackinize:

AXIAL FOACE LOA DIUG, PYH, CE WOzRLE (400 LB)

\begin{tabular}{|c|c|c|c|c|c|c|c|c|}
\hline \multirow[b]{2}{*}{ ROSETTE } & \multicolumn{3}{|c|}{ arcro-stearn } & \multicolumn{3}{|c|}{ STEESSES } & \multicolumn{2}{|c|}{ PRI STESSE } \\
\hline & GIGEI & 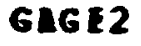 & 223 & 1 & LOEG & SEEAR & $\operatorname{cgax}$ & 510 \\
\hline 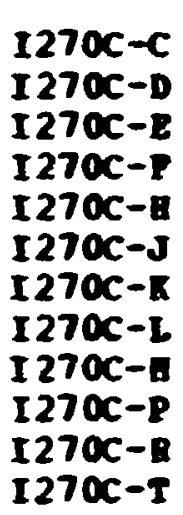 & $\begin{array}{r}-34 \\
-10 \\
7 \\
21 \\
42 \\
57 \\
52 \\
43 \\
28 \\
15 \\
8 \\
-12\end{array}$ & $\begin{array}{r}-110 \\
-77 \\
-53 \\
-36 \\
-10 \\
9 \\
7 \\
16 \\
-1 \\
-7 \\
-7 \\
-2\end{array}$ & $\begin{array}{r}-89 \\
-58 \\
-39 \\
-22 \\
2 \\
16 \\
19 \\
9 \\
-1 \\
-7 \\
-7 \\
3\end{array}$ & $\begin{array}{r}-4338 \\
-2950 \\
-2027 \\
-1256 \\
-233 \\
494 \\
501 \\
451 \\
-58 \\
-341 \\
-316 \\
37\end{array}$ & $\begin{array}{r}-2320 \\
-1188 \\
-410 \\
250 \\
1199 \\
1849 \\
1715 \\
1412 \\
822 \\
334 \\
145 \\
-345\end{array}$ & $\begin{array}{r}-286 \\
-256 \\
-191 \\
-159 \\
-159 \\
-97 \\
-161 \\
58 \\
-1 \\
3 \\
-3 \\
-64\end{array}$ & $\begin{array}{r}-2290 \\
-1151 \\
-388 \\
267 \\
1216 \\
1855 \\
1736 \\
1415 \\
822 \\
334 \\
145 \\
48\end{array}$ & $\begin{array}{r}-437 \\
-290 \\
-20 \\
-127 \\
-29 \\
48 \\
48 \\
49 \\
-5 \\
-34 \\
-31 \\
-35\end{array}$ \\
\hline $\begin{array}{l}0270 C-B \\
0270 C-C \\
0270 C-D \\
0270 C-E \\
0270 C-P \\
0270 C-B \\
0270 C-J \\
0270 C-R \\
0270 C-I \\
0270 C-B \\
0270 C-P \\
0270 C-B \\
0270 C-T\end{array}$ & $\begin{array}{r}104 \\
85 \\
71 \\
52 \\
38 \\
9 \\
-12 \\
-26 \\
-29 \\
-27 \\
-13 \\
-10 \\
4\end{array}$ & $\begin{array}{r}245 \\
166 \\
1 \equiv 1 \\
104 \\
81 \\
38 \\
2 \\
-14 \\
-26 \\
-24 \\
-17 \\
-12 \\
11\end{array}$ & $\begin{array}{r}276 \\
173 \\
140 \\
104 \\
83 \\
40 \\
0 \\
-19 \\
-29 \\
-27 \\
-22 \\
-17 \\
9\end{array}$ & $\begin{array}{r}11323 \\
7372 \\
5872 \\
4533 \\
3555 \\
1703 \\
51 \\
-712 \\
-116.4 \\
-1085 \\
-845 \\
-6.34 \\
0.43\end{array}$ & $\begin{array}{r}6533 \\
4774 \\
3895 \\
2923 \\
2201 \\
788 \\
-350 \\
-1006 \\
-1219 \\
-1128 \\
-630 \\
-492 \\
251\end{array}$ & $\begin{array}{r}-411 \\
-96 \\
-125 \\
0 \\
-32 \\
-31 \\
31 \\
64 \\
31 \\
34 \\
62 \\
64 \\
32\end{array}$ & $\begin{array}{r}11363 \\
7376 \\
5880 \\
4533 \\
3556 \\
1704 \\
53 \\
-699 \\
-1165 \\
-1069 \\
-613 \\
-468 \\
448\end{array}$ & $\begin{array}{l}-3 \\
-1 \\
-1 \\
-1 \\
-8 \\
-8\end{array}$ \\
\hline $\begin{array}{l}I 270 n-B \\
I 270 n-C \\
I 270 n-D \\
I 270 n-B \\
I 270 n-P\end{array}$ & $\begin{array}{r}-528 \\
57 \\
174 \\
148 \\
106\end{array}$ & $\begin{array}{r}24 \\
126 \\
79 \\
12 \\
-17\end{array}$ & $\begin{array}{r}7 \\
105 \\
74 \\
21 \\
-12\end{array}$ & $\begin{array}{r}1250 \\
5018 \\
3160 \\
567 \\
-748\end{array}$ & $\begin{array}{r}-15456 \\
3216 \\
6167 \\
4600 \\
2967\end{array}$ & $\begin{array}{r}222 \\
288 \\
63 \\
-126 \\
-64\end{array}$ & $\begin{array}{l}1253 \\
5063 \\
6168 \\
4604 \\
2968\end{array}$ & $\begin{array}{r}3 \\
3 \\
-\end{array}$ \\
\hline $\begin{array}{l}0270 n-B \\
0270 \pi-C \\
0270 \pi-D \\
0270 n-E \\
0270 \pi-P \\
0270 \pi-G \\
0270 \pi-A \\
02701-R \\
0270 \pi-\pi\end{array}$ & $\begin{array}{r}184 \\
7 \\
33 \\
81 \\
93 \\
95 \\
88 \\
71 \\
57\end{array}$ & $\begin{array}{r}251 \\
\text { es } \\
9 \\
-5\end{array}$ & $\begin{array}{r}270 \\
90 \\
14 \\
2 \\
7 \\
21 \\
24 \\
12 \\
4\end{array}$ & $\begin{array}{r}12132 \\
38.37 \\
479 \\
-147 \\
96 \\
573 \\
628 \\
383 \\
-126\end{array}$ & $\begin{array}{l}9170 \\
1356 \\
1138 \\
2378 \\
2805 \\
3025 \\
2823 \\
2248 \\
1666\end{array}$ & $\begin{array}{r}281 \\
-63 \\
-63 \\
-96 \\
-63 \\
-158 \\
-190 \\
-33 \\
-158\end{array}$ & $\begin{array}{l}12158 \\
3839 \\
1144 \\
2382 \\
2807 \\
3035 \\
2840 \\
2249 \\
1680\end{array}$ & $\begin{array}{l}9 \\
1\end{array}$ \\
\hline
\end{tabular}


Tabie A.6 (continised)

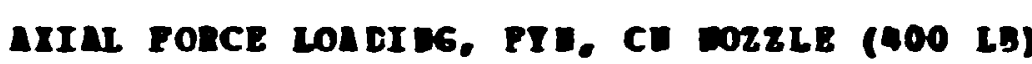

\begin{tabular}{|c|c|c|c|c|c|c|c|c|}
\hline \multirow[b]{2}{*}{ DOSETTE } & \multicolumn{3}{|c|}{ EICRO-STENTE } & \multicolumn{2}{|c|}{ STRESSES } & \multicolumn{3}{|c|}{ PRI STERSES } \\
\hline & GLGE1 & GACE2 & & TR & LOI & IEAR & $\operatorname{cen} x$ & a. \\
\hline 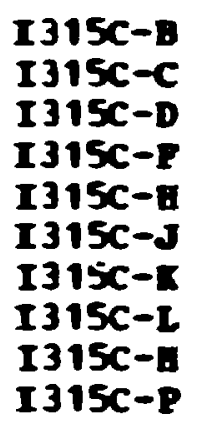 & $\begin{array}{r}-43 \\
-12 \\
7 \\
-10 \\
-17 \\
-19 \\
-19 \\
29 \\
21 \\
16\end{array}$ & $\begin{array}{l}-43 \\
-36 \\
-31 \\
-31 \\
-27 \\
-31 \\
-34 \\
-4 \\
-1 \\
-5\end{array}$ & $\begin{array}{r}-174 \\
-179 \\
-131 \\
-65 \\
-79 \\
-67 \\
-55 \\
-15 \\
7 \\
19\end{array}$ & $\begin{array}{r}-4734 \\
-4716 \\
-3569 \\
-2096 \\
-2301 \\
-2140 \\
-1928 \\
-450 \\
102 \\
291\end{array}$ & $\begin{array}{r}-2712 \\
-1777 \\
-849 \\
-921 \\
-1198 \\
-1221 \\
-1159 \\
726 \\
668 \\
574\end{array}$ & $\begin{array}{r}1751 \\
1908 \\
1344 \\
445 \\
700 \\
477 \\
286 \\
136 \\
-112 \\
-311\end{array}$ & $\begin{array}{r}-1701 \\
-838 \\
-293 \\
-771 \\
-858 \\
-1019 \\
-1064 \\
741 \\
689 \\
774\end{array}$ & $\begin{array}{r}-5745 \\
-5655 \\
-4121 \\
-2246 \\
-2641 \\
-2343 \\
-2023 \\
-465 \\
80\end{array}$ \\
\hline $\begin{array}{l}03150 \\
03150 \\
03150 \\
03150 \\
03150 \\
03150 \\
03150 \\
03130 \\
03150\end{array}$ & $\begin{array}{r}57 \\
52 \\
36 \\
24 \\
24 \\
5 \\
2 \\
12 \\
2 \\
-10\end{array}$ & $\begin{array}{r}214 \\
183 \\
187 \\
161 \\
138 \\
85 \\
12 \\
5 \\
-12 \\
-22\end{array}$ & $\begin{array}{r}107 \\
90 \\
90 \\
78 \\
62 \\
38 \\
19 \\
9 \\
5 \\
-7\end{array}$ & $\begin{array}{r}6979 \\
5942 \\
6063 \\
5242 \\
4356 \\
2699 \\
670 \\
293 \\
-164 \\
-622\end{array}$ & $\begin{array}{r}3805 \\
3351 \\
2889 \\
2286 \\
2021 \\
947 \\
268 \\
438 \\
19 \\
-475\end{array}$ & $\begin{array}{r}1422 \\
1232 \\
1296 \\
1106 \\
1012 \\
632 \\
-94 \\
-63 \\
-222 \\
-191\end{array}$ & $\begin{array}{r}7523 \\
6434 \\
6525 \\
5610 \\
4733 \\
2903 \\
691 \\
462 \\
167 \\
-344\end{array}$ & $\begin{array}{r}3261 \\
2859 \\
2427 \\
1918 \\
1644 \\
743 \\
247 \\
269 \\
-312 \\
-753\end{array}$ \\
\hline $\begin{array}{lll}I & 3 & 15 \\
I & 3 & 15 ! \\
I & 3 & 15 ! \\
I & 3 & 15 ! \\
I & 3 & 15 ! \\
I & 3 & 15 !\end{array}$ & $\begin{array}{r}-440 \\
57 \\
148 \\
119 \\
91 \\
48\end{array}$ & $\begin{array}{r}93 \\
115 \\
69 \\
16 \\
-5 \\
0\end{array}$ & $\begin{array}{r}7 \\
126 \\
81 \\
26 \\
5 \\
-10\end{array}$ & $\begin{array}{r}2686 \\
5182 \\
3136 \\
803 \\
-111 \\
-274\end{array}$ & $\begin{array}{r}-12396 \\
3269 \\
5381 \\
3819 \\
2685 \\
1357\end{array}$ & $\begin{array}{r}1148 \\
-126 \\
-159 \\
-129 \\
-128 \\
125\end{array}$ & $\begin{array}{l}2773 \\
5190 \\
5393 \\
3824 \\
2691 \\
1367\end{array}$ & $\begin{array}{r}-12483 \\
3261 \\
3125 \\
798 \\
-117 \\
-283\end{array}$ \\
\hline $\begin{array}{llll}0 & 315 \\
0 & 3 & 15 \\
0 & 3 & 15 ! \\
0 & 3 & 15 \\
0 & 315 \\
0 & 3 & 15 \\
0 & 3151 \\
0 & 3 & 15 ! \\
0 & 3 & 15 !\end{array}$ & $\begin{array}{r}154 \\
-24 \\
0 \\
42 \\
68 \\
73 \\
71 \\
66 \\
503\end{array}$ & $\begin{array}{r}275 \\
55 \\
9 \\
-9 \\
-5 \\
2 \\
2 \\
-5 \\
-7\end{array}$ & $\begin{array}{r}287 \\
81 \\
-12 \\
-23 \\
-19 \\
-5 \\
0 \\
5 \\
7\end{array}$ & $\begin{array}{r}12181 \\
3880 \\
-48 \\
-767 \\
-586 \\
-126 \\
-23 \\
-67 \\
-547\end{array}$ & $\begin{array}{r}8260 \\
449 \\
-12 \\
1040 \\
1679 \\
2149 \\
2109 \\
1955 \\
14918\end{array}$ & $\begin{array}{r}-159 \\
189 \\
280 \\
187 \\
188 \\
94 \\
31 \\
-126 \\
-188\end{array}$ & $\begin{array}{r}12188 \\
3890 \\
251 \\
1059 \\
1885 \\
2153 \\
2110 \\
1962 \\
14921\end{array}$ & $\begin{array}{r}8254 \\
439 \\
-318 \\
-786 \\
-601 \\
-130 \\
-23 \\
-75 \\
-549\end{array}$ \\
\hline
\end{tabular}


Fable i. :. Tut-of-olane force, $F_{\text {Li }}$ os sozzle

\begin{tabular}{|c|c|c|c|c|c|c|c|c|}
\hline \multirow[b]{2}{*}{ OSETTE } & \multicolumn{3}{|c|}{ AICEC-SI LAIJ } & \multicolumn{3}{|c|}{ STRESSES } & \multicolumn{2}{|c|}{ PEIU STESSES } \\
\hline & GLGET & GE2 & & & LOEG & SUEAR & SIGaX & II \\
\hline 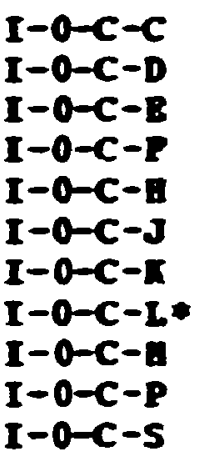 & $\begin{array}{r}12 \\
2 \\
7 \\
9 \\
0 \\
0 \\
0 \\
-136 \\
0 \\
0 \\
-1\end{array}$ & $\begin{array}{r}-322 \\
-289 \\
-234 \\
-189 \\
102 \\
64 \\
-43 \\
-27 \\
-87 \\
-8 \\
-8\end{array}$ & $\begin{array}{r}293 \\
265 \\
214 \\
179 \\
-108 \\
-69 \\
40 \\
21 \\
16 \\
9 \\
5\end{array}$ & $\begin{array}{r}-651 \\
-531 \\
-137 \\
-228 \\
-115 \\
-118 \\
-72 \\
30 \\
-11 \\
35 \\
-1\end{array}$ & $\begin{array}{r}155 \\
-94 \\
79 \\
212 \\
-44 \\
-14 \\
112 \\
-4065 \\
-12 \\
0 \\
-15\end{array}$ & $\begin{array}{r}-8199 \\
-7377 \\
-5975 \\
-4893 \\
2797 \\
1780 \\
-1110 \\
-636 \\
-446 \\
-221 \\
-137\end{array}$ & $\begin{array}{l}7960 \\
7068 \\
5802 \\
4890 \\
2718 \\
1700 \\
1134 \\
127 \\
134 \\
239 \\
130\end{array}$ & $\begin{array}{r}-8459 \\
-7693 \\
-6159 \\
-7906 \\
-2877 \\
-1862 \\
-1093 \\
-4161 \\
-457 \\
-204 \\
-146\end{array}$ \\
\hline 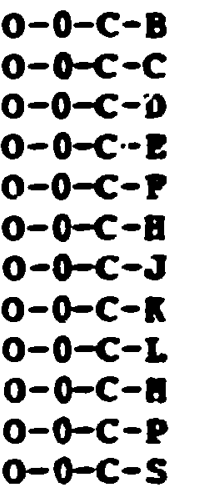 & $\begin{array}{r}5 \\
-2 \\
5 \\
5 \\
-5 \\
2 \\
-2 \\
0 \\
0 \\
0 \\
0 \\
0\end{array}$ & $\begin{array}{r}-164 \\
-171 \\
-142 \\
-114 \\
-90 \\
-55 \\
-26 \\
-19 \\
-9 \\
-9 \\
-5 \\
-8\end{array}$ & $\begin{array}{r}119 \\
142 \\
116 \\
97 \\
83 \\
47 \\
28 \\
19 \\
12 \\
7 \\
5 \\
2\end{array}$ & $\begin{array}{r}-995 \\
-622 \\
-578 \\
-370 \\
-151 \\
-159 \\
55 \\
0 \\
52 \\
-52 \\
0 \\
0\end{array}$ & $\begin{array}{r}-156 \\
-258 \\
-31 \\
31 \\
-188 \\
23 \\
-55 \\
0 \\
16 \\
-16 \\
0 \\
0\end{array}$ & $\begin{array}{r}-3758 \\
-4168 \\
-3442 \\
-2810 \\
-2305 \\
-1358 \\
-726 \\
-505 \\
-284 \\
-221 \\
-126 \\
-63\end{array}$ & $\begin{array}{r}3206 \\
3732 \\
3148 \\
2648 \\
2136 \\
1293 \\
728 \\
505 \\
319 \\
188 \\
126 \\
63\end{array}$ & $\begin{array}{r}-4357 \\
-4612 \\
-3757 \\
-2987 \\
-2475 \\
-1429 \\
-728 \\
-505 \\
-251 \\
-256 \\
-126 \\
-63\end{array}$ \\
\hline $\begin{array}{l}I-0-I-B \\
I-0-I-C \\
I-0-I-D \\
I-0-I-B \\
I-0-N-I \\
I-0-I-I\end{array}$ & $\begin{array}{r}143 \\
-12 \\
-48 \\
-43 \\
-36 \\
-134\end{array}$ & $\begin{array}{r}-319 \\
-41 \\
33 \\
36 \\
24 \\
-5\end{array}$ & $\begin{array}{r}275 \\
-24 \\
-77 \\
-50 \\
-26 \\
2\end{array}$ & $\begin{array}{r}-1112 \\
-1412 \\
-897 \\
-272 \\
-19 \\
85\end{array}$ & $\begin{array}{r}3971 \\
-790 \\
-1712 \\
-1381 \\
-1087 \\
-4003\end{array}$ & $\begin{array}{r}-7913 \\
-224 \\
1468 \\
1150 \\
669 \\
-96\end{array}$ & $\begin{array}{r}9740 \\
-718 \\
219 \\
451 \\
303 \\
87\end{array}$ & $\begin{array}{l}-6882 \\
-1484 \\
-2828 \\
-2103 \\
-1409 \\
-4005\end{array}$ \\
\hline 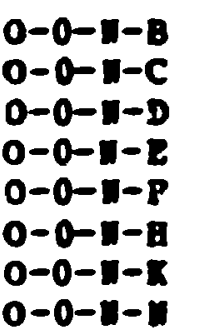 & $\begin{array}{r}-9 \\
-2 \\
-4 \\
-5 \\
-2 \\
0 \\
0 \\
0\end{array}$ & $\begin{array}{r}78 \\
45 \\
0 \\
-16 \\
-19 \\
-21 \\
-21 \\
-19\end{array}$ & $\begin{array}{r}-135 \\
-62 \\
-5 \\
17 \\
19 \\
17 \\
17 \\
46\end{array}$ & $\begin{array}{r}-1240 \\
-362 \\
-91 \\
11 \\
10 \\
-99 \\
-100 \\
596\end{array}$ & $\begin{array}{l}-656 \\
-180 \\
-162 \\
-132 \\
-61 \\
-24 \\
-20 \\
184\end{array}$ & $\begin{array}{r}2843 \\
1421 \\
65 \\
-441 \\
-506 \\
-506 \\
-504 \\
-861\end{array}$ & $\begin{array}{r}1909 \\
1153 \\
-52 \\
386 \\
482 \\
446 \\
446 \\
1276\end{array}$ & $\begin{array}{r}-3806 \\
-1595 \\
-200 \\
-507 \\
-532 \\
-568 \\
-566 \\
-495\end{array}$ \\
\hline
\end{tabular}


Sat Ie A.T (costinces)

\begin{tabular}{|c|c|c|c|c|c|c|c|c|}
\hline \multirow[b]{2}{*}{ DOSETR } & \multicolumn{3}{|c|}{ EICRO-SIEnID } & \multicolumn{3}{|c|}{ STIESSES } & \multicolumn{2}{|c|}{ PRIE STESSES } \\
\hline & GLGL. & & & 81 & LO & SaRAR & SIGax & ST \\
\hline 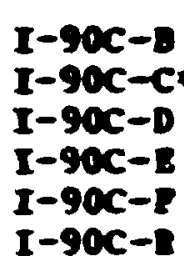 & $\begin{array}{r}-36 \\
-79 \\
-60 \\
-48 \\
-36 \\
5\end{array}$ & $\begin{array}{r}-416 \\
-328 \\
-2 \equiv 2 \\
-167 \\
-100 \\
0\end{array}$ & $\begin{array}{r}-380 \\
0 \\
-218 \\
-158 \\
-117 \\
-2\end{array}$ & $\begin{array}{r}-17469 \\
-7117 \\
-9819 \\
-7098 \\
-4745 \\
-58\end{array}$ & $\begin{array}{r}-6318 \\
-4504 \\
-4740 \\
-3565 \\
-2500 \\
126\end{array}$ & $\begin{array}{r}-478 \\
-4367 \\
-191 \\
-128 \\
223 \\
32\end{array}$ & $\begin{array}{r}-6298 \\
-1252 \\
-1733 \\
-3561 \\
-2478 \\
132\end{array}$ & $\begin{array}{r}-17490 \\
-10369 \\
-9826 \\
-7103 \\
-4767 \\
-63\end{array}$ \\
\hline ? & $\begin{array}{l}126 \\
147 \\
142 \\
128 \\
116 \\
-7\end{array}$ & $\begin{array}{r}358 \\
330 \\
280 \\
199 \\
166 \\
-7\end{array}$ & $\begin{array}{r}122 \\
361 \\
270 \\
214 \\
171 \\
-5\end{array}$ & $\begin{array}{r}17006 \\
15012 \\
11918 \\
8932 \\
7277 \\
-253\end{array}$ & $\begin{array}{l}8880 \\
6918 \\
7859 \\
6524 \\
5671 \\
-289\end{array}$ & $\begin{array}{r}-851 \\
-411 \\
126 \\
-190 \\
-63 \\
-32\end{array}$ & $\begin{array}{r}17094 \\
15040 \\
11945 \\
8947 \\
7279 \\
-235\end{array}$ & $\begin{array}{l}8792 \\
8890 \\
7850 \\
6509 \\
5669 \\
-308\end{array}$ \\
\hline $\begin{array}{l}I-9 \\
I-9\end{array}$ & $\begin{array}{r}-1002 \\
203 \\
113 \\
348 \\
40 \\
217\end{array}$ & $\begin{array}{r}117 \\
193 \\
167 \\
-7 \\
-43 \\
117\end{array}$ & $\begin{array}{r}-119 \\
203 \\
167 \\
74 \\
4 \\
79\end{array}$ & $\begin{array}{l}1048 \\
8474 \\
5573 \\
1086 \\
-895 \\
4064\end{array}$ & $\begin{array}{r}-29749 \\
8619 \\
14051 \\
10770 \\
936 \\
7737\end{array}$ & $\begin{array}{r}3147 \\
-127 \\
-793 \\
-1079 \\
-634 \\
509\end{array}$ & $\begin{array}{r}1366 \\
8692 \\
14125 \\
10889 \\
1134 \\
7806\end{array}$ & $\begin{array}{r}-30067 \\
8401 \\
5500 \\
967 \\
-1093 \\
3994\end{array}$ \\
\hline $\begin{array}{l}-9 \\
-9 \\
-9 \\
-9 \\
-9\end{array}$ & $\begin{array}{r}432 \\
97 \\
152 \\
171 \\
204 \\
114\end{array}$ & $\begin{array}{r}669 \\
1 \in 5 \\
15 \\
-14 \\
57 \\
-2\end{array}$ & $\begin{array}{r}672 \\
202 \\
24 \\
0 \\
5 \\
7\end{array}$ & $\begin{array}{r}28587 \\
8393 \\
772 \\
-500 \\
1131 \\
-21\end{array}$ & $\begin{array}{r}21652 \\
5437 \\
4787 \\
4974 \\
6459 \\
3410\end{array}$ & $\begin{array}{r}-32 \\
-221 \\
-63 \\
-190 \\
695 \\
-126\end{array}$ & $\begin{array}{r}28987 \\
8409 \\
4788 \\
4980 \\
6549 \\
3414\end{array}$ & $\begin{array}{r}21652 \\
5420 \\
771 \\
-507 \\
1042 \\
-25\end{array}$ \\
\hline
\end{tabular}




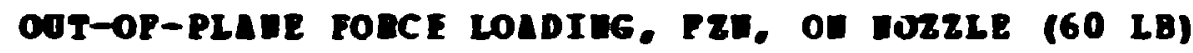

AICRC-STEAI

- -

ROSETTE GAGE1 GAGE2 GAGE3

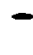

\begin{tabular}{|c|c|c|c|c|c|c|c|c|}
\hline $\begin{array}{l}180 C-B \\
180 C-C \\
180 C-D \\
180 C-E \\
180 C-F \\
189 C-5\end{array}$ & $\begin{array}{r}-33 \\
-23 \\
-18 \\
-12 \\
-9 \\
1\end{array}$ & $\begin{array}{r}271 \\
3 \leq 2 \\
271 \\
238 \\
189 \\
1\end{array}$ & $\begin{array}{r}-212 \\
-278 \\
-238 \\
-202 \\
-162 \\
-2\end{array}$ & $\begin{array}{r}1343 \\
1645 \\
760 \\
804 \\
592 \\
-28\end{array}$ & $\begin{array}{r}-580 \\
-206 \\
-325 \\
-104 \\
-99 \\
11\end{array}$ & $\begin{array}{l}6440 \\
8388 \\
6785 \\
5873 \\
4680\end{array}$ & $\begin{array}{r}6893 \\
9158 \\
7023 \\
6241 \\
4939 \\
28\end{array}$ & $\begin{array}{r}-6130 \\
-7719 \\
-6589 \\
-5540 \\
-4446 \\
-46\end{array}$ \\
\hline $\begin{array}{l}C-B \\
C-C \\
C-D \\
C-E \\
C-F \\
C-S\end{array}$ & $\begin{array}{r}17 \\
8 \\
10 \\
5 \\
2 \\
-20\end{array}$ & $\begin{array}{r}1 \leq 0 \\
1 \leq 7 \\
129 \\
103 \\
83 \\
0\end{array}$ & $\begin{array}{r}-173 \\
-183 \\
-145 \\
-114 \\
-91 \\
-7\end{array}$ & $\begin{array}{l}-5 \\
-5 \\
-3 \\
-2 \\
-1 \\
-1\end{array}$ & $\begin{array}{r}354 \\
58 \\
191 \\
78 \\
12 \\
-643\end{array}$ & & $\begin{array}{l}4 \\
3 \\
2 \\
2 \\
-\end{array}$ & $\begin{array}{l}-4 \\
-4 \\
-3 \\
-2 \\
-2 \\
-\end{array}$ \\
\hline $\begin{array}{l}180 n-B \\
180 \pi-C \\
180 \pi-D \\
180 \pi-E \\
180 \pi-P \\
180 \pi-1\end{array}$ & $\begin{array}{r}-54 \\
10 \\
12 \\
3 \\
-2 \\
22\end{array}$ & $\begin{array}{r}403 \\
86 \\
29 \\
-54 \\
-35 \\
-16\end{array}$ & $\begin{array}{r}-279 \\
-14 \\
41 \\
38 \\
21 \\
5\end{array}$ & $\begin{array}{l}2800 \\
1573 \\
1519 \\
-357 \\
-299 \\
-270\end{array}$ & $\begin{array}{r}-795 \\
766 \\
822 \\
-28 \\
-153 \\
571\end{array}$ & $\begin{array}{r}90 \\
13 \\
-1 \\
-12 \\
-7 \\
-2\end{array}$ & $\begin{array}{r}10265 \\
2564 \\
1553 \\
1056 \\
531 \\
658\end{array}$ & $\begin{array}{r}-8250 \\
-225 \\
788 \\
-1441 \\
-982 \\
-357\end{array}$ \\
\hline $\begin{array}{l}180 \\
180\end{array}$ & $\begin{array}{l}5 \\
7 \\
0 \\
c \\
0\end{array}$ & $\begin{array}{r}-113 \\
-48 \\
5 \\
24 \\
24 \\
19\end{array}$ & $\begin{array}{r}40 \\
36 \\
7 \\
-14 \\
-19 \\
-17\end{array}$ & $\begin{array}{r}-1595 \\
-276 \\
255 \\
205 \\
102 \\
37\end{array}$ & $\begin{array}{r}-342 \\
126 \\
70 \\
55 \\
28 \\
186\end{array}$ & $\begin{array}{r}-2039 \\
-1109 \\
-33 \\
505 \\
571 \\
475\end{array}$ & $\begin{array}{r}1165 \\
1052 \\
260 \\
641 \\
637 \\
570\end{array}$ & $\begin{array}{r}-3102 \\
-1202 \\
64 \\
-381 \\
-507 \\
-387\end{array}$ \\
\hline
\end{tabular}


atle A. $\bar{f}$ (conti:auej)

OOT-OP-PLAHE FOBCE LOADIMG, PZH, OU MOZZLE (60 LB)

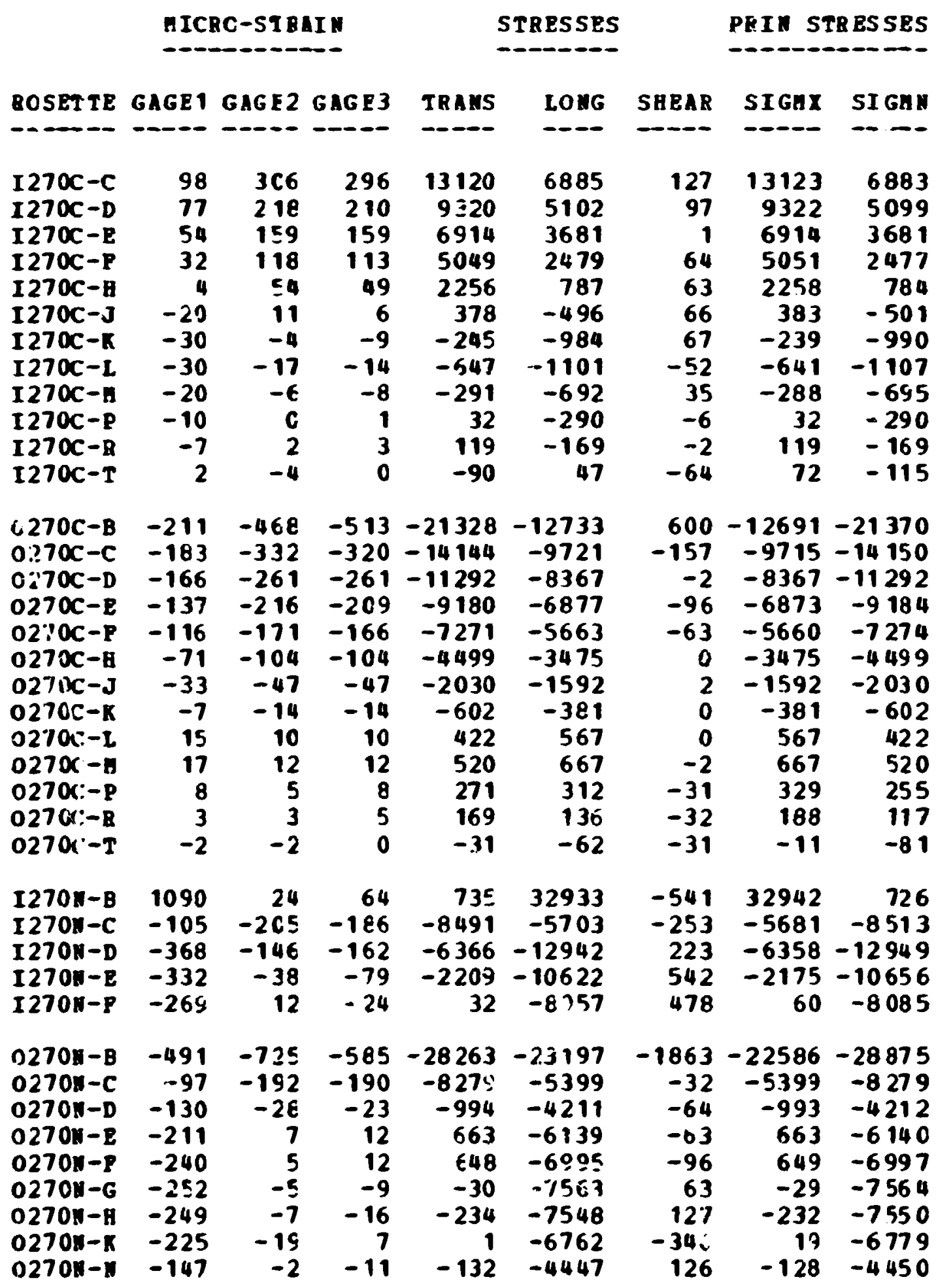


Tó̀ie \&. $T$ (continued)

OUT-OP-PLAME FOBCE LOADIEG, PZH, OH MOZZLE (60 LB)

HICRO-SIBNT:

$-\infty-\infty-\infty-0-0$

ROSETTE GAGE! GAGE2 GAGE3

\begin{tabular}{|c|c|c|c|c|c|c|c|c|}
\hline \multirow[b]{2}{*}{ ROSETTE } & & & \\
\hline & GLGE? & GLGE2 & GAGE3 & TRAUS & LOWG & SERAR & SIGRX & SI GE \\
\hline 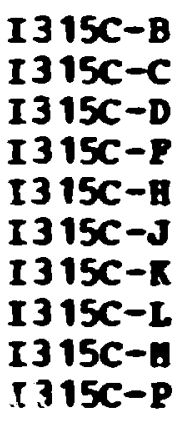 & $\begin{array}{r}67 \\
55 \\
50 \\
81 \\
100 \\
93 \\
81 \\
-7 \\
-12 \\
-19\end{array}$ & $\begin{array}{l}69 \\
26 \\
10 \\
67 \\
67 \\
74 \\
76 \\
4 \\
6 \\
0\end{array}$ & $\begin{array}{r}470 \\
456 \\
315 \\
141 \\
167 \\
141 \\
122 \\
58 \\
29 \\
5\end{array}$ & $\begin{array}{l}11784 \\
10538 \\
7083 \\
4475 \\
5032 \\
4620 \\
4266 \\
1373 \\
781 \\
127\end{array}$ & $\begin{array}{r}5541 \\
4809 \\
3629 \\
3778 \\
4518 \\
4179 \\
3715 \\
196 \\
-117 \\
-376\end{array}$ & $\begin{array}{r}-5344 \\
-5726 \\
-4070 \\
-986 \\
-1336 \\
-891 \\
-604 \\
-709 \\
-302 \\
-71\end{array}$ & $\begin{array}{r}14851 \\
14076 \\
9777 \\
5173 \\
6135 \\
5317 \\
4654 \\
1706 \\
874 \\
137\end{array}$ & $\begin{array}{r}2474 \\
1271 \\
935 \\
3081 \\
3414 \\
3482 \\
3326 \\
-137 \\
-209 \\
-386\end{array}$ \\
\hline 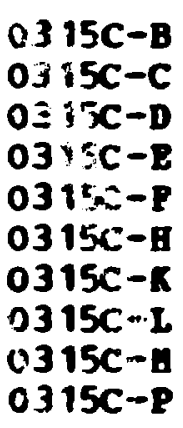 & $\begin{array}{l}-95 \\
-85 \\
-59 \\
-40 \\
-43 \\
-19 \\
-9 \\
-12 \\
-9 \\
-5\end{array}$ & $\begin{array}{r}-384 \\
-3 \equiv 2 \\
-346 \\
-292 \\
-244 \\
-176 \\
-76 \\
-43 \\
-19 \\
0\end{array}$ & $\begin{array}{l}-107 \\
-81 \\
-78 \\
-71 \\
-55 \\
-47 \\
-36 \\
-31 \\
-24 \\
-12\end{array}$ & $\begin{array}{r}-10686 \\
-8977 \\
-9266 \\
-7931 \\
-6521 \\
-4879 \\
-2440 \\
-1603 \\
-928 \\
-255\end{array}$ & $\begin{array}{r}-6053 \\
-5255 \\
-4559 \\
-3589 \\
-3237 \\
-2033 \\
-1017 \\
-837 \\
-563 \\
-219\end{array}$ & $\begin{array}{r}-3698 \\
-3350 \\
-3571 \\
-2939 \\
-2528 \\
-1707 \\
-537 \\
-158 \\
63 \\
158\end{array}$ & $\begin{array}{r}-4006 \\
-3284 \\
-2635 \\
-2106 \\
-1865 \\
-1234 \\
-837 \\
-805 \\
-552 \\
-78\end{array}$ & $\begin{array}{r}-12733 \\
-10948 \\
-11189 \\
-9414 \\
-7894 \\
-5678 \\
-2620 \\
-1634 \\
-939 \\
-396\end{array}$ \\
\hline 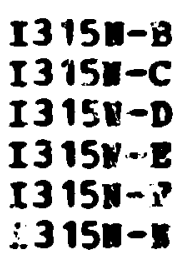 & $\begin{array}{r}749 \\
-103 \\
-275 \\
-244 \\
-201 \\
-105\end{array}$ & $\begin{array}{r}-220 \\
-1 \leq 0 \\
-76 \\
-12 \\
10 \\
12\end{array}$ & $\begin{array}{r}120 \\
-201 \\
-174 \\
-88 \\
-45 \\
0\end{array}$ & $\begin{array}{r}-3025 \\
-7602 \\
-5204 \\
-1928 \\
-557 \\
388\end{array}$ & $\begin{array}{l}21548 \\
-5359 \\
-9804 \\
-7886 \\
-6185 \\
-3021\end{array}$ & $\begin{array}{r}-4524 \\
668 \\
1306 \\
1021 \\
733 \\
158\end{array}$ & $\begin{array}{r}22355 \\
-5175 \\
-4859 \\
-1758 \\
-463 \\
395\end{array}$ & $\begin{array}{r}-3831 \\
-7786 \\
-10149 \\
-8056 \\
-6279 \\
-3028\end{array}$ \\
\hline $\begin{array}{l}0315 n-8 \\
0315 n-C \\
0315 n-D \\
0315 n-E \\
0315 n-E \\
0315 n-G \\
0315 n-E \\
0315 n-R \\
0315 n-n\end{array}$ & $\begin{array}{r}-346 \\
-64 \\
-91 \\
-145 \\
-180 \\
-187 \\
-178 \\
-159 \\
-33\end{array}$ & $\begin{array}{r}-415 \\
-116 \\
-7 \\
14 \\
3 \\
-9 \\
-9 \\
-7 \\
-9\end{array}$ & $\begin{array}{r}-572 \\
-202 \\
-30 \\
19 \\
19 \\
5\end{array}$ & $\begin{array}{r}-21305 \\
-6915 \\
-716 \\
885 \\
673 \\
116 \\
101 \\
85 \\
-55\end{array}$ & $\begin{array}{r}-16782 \\
-3996 \\
-2955 \\
-4095 \\
-5211 \\
-5590 \\
-5314 \\
-4756 \\
-992\end{array}$ & $\begin{array}{r}2086 \\
1138 \\
310 \\
-65 \\
-218 \\
-186 \\
-188 \\
-126 \\
-188\end{array}$ & $\begin{array}{r}-15967 \\
-3605 \\
-674 \\
886 \\
681 \\
122 \\
107 \\
88 \\
-18\end{array}$ & $\begin{array}{r}-22120 \\
-7306 \\
-2997 \\
-4096 \\
-5219 \\
-5596 \\
-5320 \\
-4760 \\
-1029\end{array}$ \\
\hline
\end{tabular}

PRIM STRESSES

3TRESSES

---0--0- 
Table A.8. Torsional monent loading, 'MC' on cylinder

TORSIOHAL GOABWT LOADIMG, GXC, ON CXLIMDER (30000 TH-LB)

GICRO-STRAIN

BOSETTE GAGE1 GAGE2 GAGE3

$I-0-C-C$

$I-0-C-D$

$\mathrm{I}-\mathbf{0}-\mathrm{C}-\mathrm{B}$

$I-0-C-P$

$\mathbf{I}-\mathbf{0}-\mathbf{C}-\mathbf{B}$

$I-0-C-J$

$I-0-C-R$

$\mathrm{I}-\mathbf{0}-\mathrm{C}-\mathrm{I}$

$I-0-C-0$

$\mathrm{I}-\mathrm{O}-\mathrm{C}-\mathrm{P}$

$I-i-C-5$

$0-0-C-B$

$0-0-c-c$

$0-0-C-D$

$0-0-C-B$

$0-0-c-p$

$0-0-c-\mathrm{B}$

$0-0-C-J$

$0-0-c-\pi$

$0-0-c-1$

$0-0-c-B$

$0-0-c-p$

$0-0-c-s$

$I-0-1 B-B$

$I-0-n-C$

$I-0-n-D$

$I-0-\pi-B$

$I-0-B-P$

$I-0-n-1$

$0-0-\pi-B$

$0-0-n-C$

0-0-B-D

$0-0-1-B$

$0-0-n-P$

O-0-B-B

$0-0-n-K$

$0-0-1]-1$
STRES SES

PRII STRES SBS

\begin{tabular}{|c|c|c|c|c|c|c|c|}
\hline E1 & E & & Ans & LOIG & SAEAR & SIGaX & SIGA \\
\hline $\begin{array}{r}-3 \\
2 \\
5 \\
7 \\
2 \\
4 \\
7 \\
0 \\
4 \\
-1 \\
-3\end{array}$ & $\begin{array}{l}-51 \\
-60 \\
-53 \\
-46 \\
43 \\
35 \\
-34 \\
-39 \\
-36 \\
-32 \\
-32\end{array}$ & $\begin{array}{r}40 \\
57 \\
52 \\
52 \\
-39 \\
-39 \\
35 \\
33 \\
35 \\
37 \\
36\end{array}$ & $\begin{array}{r}-225 \\
-71 \\
-21 \\
138 \\
87 \\
-78 \\
23 \\
-127 \\
-21 \\
131 \\
102\end{array}$ & $\begin{array}{r}-149 \\
41 \\
130 \\
247 \\
83 \\
106 \\
207 \\
-29 \\
123 \\
23 \\
-64\end{array}$ & $\begin{array}{r}-1208 \\
-1557 \\
-1398 \\
-1302 \\
108 \\
986 \\
-918 \\
-954 \\
-955 \\
-920 \\
-904\end{array}$ & $\begin{array}{r}1022 \\
1543 \\
1455 \\
1496 \\
1166 \\
1005 \\
1037 \\
877 \\
1009 \\
999 \\
926\end{array}$ & $\begin{array}{r}-1396 \\
-1573 \\
-1346 \\
-1111 \\
-996 \\
-976 \\
-807 \\
-1033 \\
-907 \\
-845 \\
-888\end{array}$ \\
\hline $\begin{array}{r}-5 \\
0 \\
-2 \\
-2 \\
3 \\
-2 \\
0 \\
0 \\
0 \\
0 \\
3 \\
-2\end{array}$ & $\begin{array}{l}55 \\
52 \\
57 \\
55 \\
50 \\
45 \\
40 \\
38 \\
36 \\
38 \\
33 \\
38\end{array}$ & $\begin{array}{l}-64 \\
-57 \\
-54 \\
-57 \\
-57 \\
-47 \\
-47 \\
-45 \\
-38 \\
-35 \\
-40 \\
-35\end{array}$ & $\begin{array}{r}-199 \\
-97 \\
61 \\
-40 \\
-152 \\
-41 \\
-147 \\
-147 \\
-44 \\
61 \\
-151 \\
63\end{array}$ & $\begin{array}{r}-197 \\
-25 \\
-47 \\
-77 \\
32 \\
-78 \\
-35 \\
-37 \\
-5 \\
25 \\
33 \\
-42\end{array}$ & $\begin{array}{l}1578 \\
1453 \\
1484 \\
1483 \\
1422 \\
1231 \\
1167 \\
1105 \\
980 \\
980 \\
979 \\
979\end{array}$ & $\begin{array}{l}1380 \\
1392 \\
1491 \\
1424 \\
1365 \\
1172 \\
1078 \\
1015 \\
955 \\
1023 \\
924 \\
991\end{array}$ & $\begin{array}{r}-1776 \\
-1515 \\
-1478 \\
-1541 \\
-1435 \\
-1291 \\
-1259 \\
-1198 \\
-1004 \\
-937 \\
-1042 \\
-470\end{array}$ \\
\hline $\begin{array}{r}7 \\
-10 \\
-7 \\
-5 \\
0 \\
2\end{array}$ & $\begin{array}{r}-17 \\
-7 \\
-5 \\
-7 \\
-7 \\
0\end{array}$ & $\begin{array}{r}-24 \\
-22 \\
-12 \\
-2 \\
0 \\
2\end{array}$ & $\begin{array}{r}-904 \\
-622 \\
-362 \\
-206 \\
-159 \\
48\end{array}$ & $\begin{array}{r}-57 \\
-476 \\
-325 \\
-207 \\
-49 \\
85\end{array}$ & $\begin{array}{r}96 \\
191 \\
96 \\
-63 \\
-96 \\
-32\end{array}$ & $\begin{array}{r}-46 \\
-344 \\
-246 \\
-143 \\
7 \\
104\end{array}$ & $\begin{array}{r}-915 \\
-754 \\
-441 \\
-270 \\
-215 \\
30\end{array}$ \\
\hline $\begin{array}{r}0 \\
-2 \\
-4 \\
-2 \\
-2 \\
-2 \\
-2 \\
-2\end{array}$ & $\begin{array}{l}17 \\
-2 \\
-7 \\
-9 \\
-7 \\
-7 \\
-5 \\
0\end{array}$ & $\begin{array}{r}-24 \\
0 \\
12 \\
10 \\
10 \\
7 \\
3 \\
-1\end{array}$ & $\begin{array}{r}-149 \\
-38 \\
125 \\
14 \\
70 \\
14 \\
-42 \\
-1\end{array}$ & $\begin{array}{l}-40 \\
-76 \\
-91 \\
-54 \\
-36 \\
-57 \\
-6,6 \\
-61\end{array}$ & $\begin{array}{r}537 \\
-31 \\
-250 \\
-251 \\
-223 \\
-190 \\
-93 \\
13\end{array}$ & $\begin{array}{r}446 \\
-20 \\
290 \\
23 ? \\
246 \\
171 \\
40 \\
1\end{array}$ & $\begin{array}{r}-634 \\
-93 \\
-255 \\
-273 \\
-212 \\
-215 \\
-168 \\
-64\end{array}$ \\
\hline
\end{tabular}


TORSIOHAL MOAENT IOADIMG, aXC, OS CILINDER (30000 In-LB)

\begin{tabular}{|c|c|c|c|c|c|c|c|c|}
\hline \multirow[b]{2}{*}{ ROSETTE } & \multicolumn{3}{|c|}{ AICRO-SIRII } & \multicolumn{3}{|c|}{ STRESSES } & \multicolumn{2}{|c|}{ PRIII STRESSES } \\
\hline & 81 & $\triangle G E 2$ & 623 & TRnes & $10 \pm 6$ & SEBAR & SIGAX & SIEA \\
\hline $\begin{array}{l}I-90 C-B \\
I-90 C-C \\
I-90 C-D \\
I-90 C-B \\
I-90 C-8 \\
I-90 C-B\end{array}$ & $\begin{array}{l}3 \\
3 \\
3 \\
3 \\
3 \\
3\end{array}$ & $\begin{array}{l}36 \\
55 \\
55 \\
53 \\
57 \\
29\end{array}$ & $\begin{array}{r}-24 \\
0 \\
-52 \\
-52 \\
-48 \\
-31\end{array}$ & $\begin{array}{r}268 \\
1212 \\
62 \\
11 \\
199 \\
-41\end{array}$ & $\begin{array}{r}161 \\
445 \\
98 \\
86 \\
142 \\
71\end{array}$ & $\begin{array}{r}798 \\
737 \\
1434 \\
1403 \\
1391 \\
796\end{array}$ & $\begin{array}{r}1015 \\
1659 \\
1514 \\
1452 \\
1562 \\
813\end{array}$ & $\begin{array}{r}-585 \\
-2 \\
-1355 \\
-1355 \\
-1221 \\
-783\end{array}$ \\
\hline $\begin{array}{l}0-90 C-B \\
0-90 C-C \\
0-90 C-D \\
0-90 C-Z \\
0-90 C-Z \\
0-90 C-B\end{array}$ & $\begin{array}{l}8 \\
5 \\
2 \\
2 \\
0 \\
0\end{array}$ & $\begin{array}{l}-35 \\
-55 \\
-57 \\
-57 \\
-55 \\
-38\end{array}$ & $\begin{array}{r}36 \\
50 \\
9 \\
97 \\
52 \\
33\end{array}$ & $\begin{array}{r}14 \\
-109 \\
-1045 \\
-211 \\
-52 \\
-104\end{array}$ & $\begin{array}{r}236 \\
110 \\
-242 \\
8 \\
-16 \\
-31\end{array}$ & $\begin{array}{r}-944 \\
-1391 \\
-885 \\
-1391 \\
-1422 \\
-948\end{array}$ & $\begin{array}{r}1075 \\
1395 \\
328 \\
1293 \\
1389 \\
881\end{array}$ & $\begin{array}{r}-826 \\
-1395 \\
-1616 \\
-3497 \\
-1456 \\
-1017\end{array}$ \\
\hline $\begin{array}{l}I-90 I-B \\
I-90 I-C \\
I-90 I-D \\
I-90 I-E \\
I-90 I-F \\
I-90 I-I\end{array}$ & $\begin{array}{r}3 \\
-17 \\
-9 \\
-4 \\
35 \\
-16\end{array}$ & $\begin{array}{l}-29 \\
-26 \\
-12 \\
-5 \\
-34 \\
-12\end{array}$ & $\begin{array}{r}-24 \\
-12 \\
-5 \\
-7 \\
7 \\
-7\end{array}$ & $\begin{array}{r}-1153 \\
-828 \\
-354 \\
-254 \\
-633 \\
-384\end{array}$ & $\begin{array}{r}-266 \\
-758 \\
-380 \\
-210 \\
864 \\
-606\end{array}$ & $\begin{array}{r}-64 \\
-190 \\
-94 \\
33 \\
-539 \\
-64\end{array}$ & $\begin{array}{l}-262 \\
-599 \\
-272 \\
-192 \\
1037 \\
-367\end{array}$ & $\begin{array}{r}-1158 \\
-986 \\
-462 \\
-272 \\
-807 \\
-623\end{array}$ \\
\hline 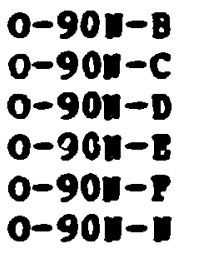 & $\begin{array}{r}-5 \\
-2 \\
0 \\
2 \\
2 \\
0\end{array}$ & $\begin{array}{r}-20 \\
-5 \\
2 \\
7 \\
5 \\
0\end{array}$ & $\begin{array}{r}28 \\
0 \\
-9 \\
-7 \\
-7 \\
0\end{array}$ & $\begin{array}{r}109 \\
-102 \\
-156 \\
-3 \\
-55 \\
0\end{array}$ & $\begin{array}{r}-110 \\
-102 \\
-47 \\
70 \\
55 \\
0\end{array}$ & $\begin{array}{r}-695 \\
-63 \\
158 \\
190 \\
158 \\
0\end{array}$ & $\begin{array}{r}704 \\
-38 \\
66 \\
227 \\
167 \\
0\end{array}$ & $\begin{array}{r}-704 \\
-165 \\
-269 \\
-159 \\
-167 \\
0\end{array}$ \\
\hline
\end{tabular}


Toóie Á.ô (continuedi)

TORSIOULL GOEET IOLDING, BXC, ON CIL IIDER (30000 II-LB)

ATCBO-STRATE

$-\infty-\infty-$

POSETTE GAGEI GIGE2 GLGE3

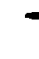

\begin{tabular}{|c|c|c|c|c|c|c|c|c|}
\hline $\begin{array}{l}I 180 C-B \\
\text { I } 180 C-C \\
I 180 C-D \\
I 180 C-B \\
\text { I } 180 C-F \\
I 180 C-S\end{array}$ & $\begin{array}{l}5 \\
5 \\
5 \\
3 \\
3 \\
3\end{array}$ & $\begin{array}{l}-21 \\
-44 \\
-49 \\
-52 \\
-67 \\
-28\end{array}$ & $\begin{array}{l}27 \\
50 \\
55 \\
52 \\
47 \\
34\end{array}$ & $\begin{array}{r}126 \\
111 \\
112 \\
12 \\
9 \\
125\end{array}$ & $\begin{array}{r}187 \\
182 \\
180 \\
83 \\
80 \\
128\end{array}$ & $\begin{array}{r}-636 \\
-1255 \\
-1382 \\
-1382 \\
-1256 \\
-816\end{array}$ & $\begin{array}{r}793 \\
1402 \\
1532 \\
1430 \\
1301 \\
943\end{array}$ & $\begin{array}{r}-881 \\
-1108 \\
-1232 \\
-1336 \\
-1213 \\
-690\end{array}$ \\
\hline $\begin{array}{l}0180 C-B \\
0180 C-C \\
0180 C-D \\
0180 C-E \\
0180 C-F \\
0180 C-S\end{array}$ & $\begin{array}{l}3 \\
1 \\
5 \\
5 \\
0 \\
0\end{array}$ & $\begin{array}{l}50 \\
53 \\
55 \\
55 \\
50 \\
28\end{array}$ & $\begin{array}{l}-57 \\
-57 \\
-59 \\
-57 \\
-57 \\
-41\end{array}$ & $\begin{array}{r}-145 \\
-87 \\
-101 \\
-45 \\
-174 \\
-277\end{array}$ & $\begin{array}{r}42 \\
-8 \\
131 \\
145 \\
-64 \\
-83\end{array}$ & $\begin{array}{r}1429 \\
1457 \\
1528 \\
1491 \\
1426 \\
917\end{array}$ & $\begin{array}{l}1381 \\
1410 \\
1544 \\
1544 \\
1308 \\
741\end{array}$ & $\begin{array}{l}-1483 \\
-1505 \\
-1513 \\
-1445 \\
-1546 \\
-1102\end{array}$ \\
\hline 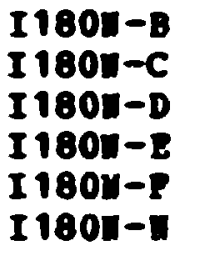 & $\begin{array}{r}3 \\
-2 \\
-2 \\
0 \\
0 \\
-2\end{array}$ & $\begin{array}{r}-2 \\
1 \\
-2 \\
-2 \\
-2 \\
1\end{array}$ & $\begin{array}{r}-19 \\
-16 \\
-11 \\
-4 \\
5 \\
-2\end{array}$ & $\begin{array}{r}-446 \\
-342 \\
-289 \\
-134 \\
64 \\
-21\end{array}$ & $\begin{array}{r}-44 \\
-900 \\
-142 \\
-25 \\
26 \\
-63\end{array}$ & $\begin{array}{r}226 \\
224 \\
128 \\
34 \\
-93 \\
34\end{array}$ & $\begin{array}{r}58 \\
-10 \\
-67 \\
-16 \\
138 \\
-2\end{array}$ & $\begin{array}{r}-547 \\
-493 \\
-363 \\
-144 \\
-51 \\
-82\end{array}$ \\
\hline $\begin{array}{l}01801-B \\
0180 \pi-C \\
01801-D \\
0180 \pi-B \\
0180 \pi-F \\
0180 \pi-Z\end{array}$ & $\begin{array}{r}-10 \\
2 \\
2 \\
2 \\
2 \\
0\end{array}$ & $\begin{array}{r}14 \\
0 \\
-10 \\
-10 \\
-7 \\
0\end{array}$ & $\begin{array}{r}-7 \\
0 \\
5 \\
9 \\
7 \\
0\end{array}$ & $\begin{array}{r}161 \\
-14 \\
-117 \\
-8 \\
-6 \\
-15\end{array}$ & $\begin{array}{r}-245 \\
60 \\
25 \\
58 \\
65 \\
-16\end{array}$ & $\begin{array}{r}284 \\
-1 \\
-192 \\
-256 \\
-190 \\
0\end{array}$ & $\begin{array}{r}307 \\
60 \\
159 \\
283 \\
222 \\
-15\end{array}$ & $\begin{array}{r}-391 \\
-14 \\
-251 \\
-233 \\
-163 \\
-16\end{array}$ \\
\hline
\end{tabular}


Table A.8 (continued)

TORSIOULL GOAEMT ICADIMG, MXC, OI CILIEDER (30000 IM-LB)

AICRO-STERT

GIGI GAGE2 GAGE3

coserte

$12700-C$

$1270 C-D$

$1270 C-8$

I270C-P

$1270 \mathrm{C}-\mathrm{B}$

I $270 \mathrm{C}-\mathrm{J}$

I $270 \mathrm{C}-\mathrm{K}$

I $270 \mathrm{C}-\mathrm{L}$

I270C-B

$1270 C-P$

I270C-R

I270C-T

$0270 C-B$

$0270 \mathrm{C}-\mathrm{C}$

0270C-D

0270C-E

$0270 \mathrm{C}-\mathrm{P}$

$0270 \mathrm{C}-\mathrm{B}$

$0270 \mathrm{C}-\mathrm{J}$

$0270 \mathrm{C}-\mathrm{K}$

$0270 \mathrm{C}-\mathrm{I}$

$0270 C-B$

$0270 C-P$

$0270 \mathrm{C}-\mathrm{R}$

O270C-T*

I270E-B

I 270I-C

I 270I-D

I270I-E

I 270 $-\mathrm{F}$

O270N-B

$0270 \mathrm{O}-\mathrm{C}$

0270I-D

O270N-E

O270N-P

0270N-G

O 270N-B

0270R-K

$0270 \mathrm{~K}-\mathrm{N}$

STRESSES

PRIN STRES SES

$-1$

1

0
-2

$-2$

5

$-2$

$-2$

$-2$

0

2

5

$-2 \quad-55$

$-5$

0

$\begin{array}{ll}0 & -57\end{array}$

$0-52$

$-4 \quad-50$

$0 \quad-47$

$3-40$

$3-43$

$1 \quad-38$

$-4 \quad-40$

$-2-40$

$-42$

$\begin{array}{rr}7 & 4 \\ -2 & 12 \\ 0 & 9 \\ 2 & 2 \\ 5 & -2\end{array}$

$-2$

$-2$

$-2$

$0 \quad 10$

0
-2
-2

$-2$

$-2$

$-2$

$-2$

-28
-5
7
10
7
7
2
-2
TRANS

Loye

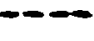

$-12$

75

35

$-35$

22

129

$-90$

$-94$

$-34$

$-30$

96

123

$-19$

$-66$

$-39$

107

2

$-7$

$-10$

$-10$

$-10$

$-10$

$-2$

$-2$
119

$-95$

$-95$

10

17

14

59

$-95$

$-33$

$-130$

$-137$

$-931$

250

198

199

93

51

-39
-2100

$-21$

$$
10
$$

$-129$

13$$
96
$$$$
50
$$$$
6
$$

$-162$

$-96$

$-255$

63

193

194

161

105

$$
\begin{array}{r}
-95 \\
-44 \\
3 \\
0 \\
-52 \\
-50 \\
-50 \\
3 \\
-102
\end{array}
$$$$
-9
$$

-92
-80

$-71$

0

$-16$

$-86$

$-86$

$-71$
SBEAE

1493
1528
1493
1366
1207
1017
29
815
859
95
102
479

S IGaX

SIGI

$$
-1522
$$

$-1458$

$-1460$

$-1458$

$-1395$

$-1332$

$-1267$

$-1110$

$-1077$

$-985$

$-982$

$-984$

$-564$

$$
\begin{array}{r}
32 \\
-189 \\
-127 \\
1 \\
95
\end{array}
$$

-694
-95

-95
190

254

222

$2 ? 2$

222

63

$$
\begin{array}{rr}
1538 & -1450 \\
1642 & -1416 \\
1548 & -1439 \\
1388 & -1347 \\
1229 & -1184 \\
1041 & -1006 \\
802 & -980 \\
115 & -915 \\
882 & -840 \\
889 & -1014 \\
1120 & -924 \\
516 & -459 \\
& \\
1558 & -1490 \\
1471 & -1452 \\
1402 & -1518 \\
1401 & -1517 \\
1405 & -1385 \\
1278 & -1390 \\
1281 & -1253 \\
1188 & -1032 \\
1058 & -1102 \\
972 & -999 \\
836 & -1128 \\
867 & -1101 \\
65 & -1250
\end{array}
$$

$255 \quad 57$

385

324

161

177

93

$-21$

$600 \quad-787$

$34-159$

$160-228$

$254-254$

$189-257$

$\begin{array}{ll}155 & -291\end{array}$

$\begin{array}{ll}155 & -291\end{array}$

$39-107$

$-102-102$ 
Table A.8 (continuec)

TORSIOHAL MOAENT LCADIMG, BXC, OK CTLIMDER (30000 IM-LB)

MICRO-STEAIM

- - - - - - -

ROSETTE GAGE1 GAGE2 GAGE3

\begin{tabular}{|c|c|c|c|c|c|c|c|c|}
\hline 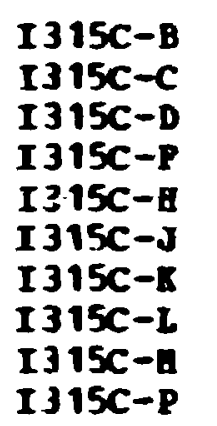 & $\begin{array}{r}12 \\
12 \\
9 \\
0 \\
-2 \\
3 \\
8 \\
41 \\
43 \\
44\end{array}$ & $\begin{array}{l}-91 \\
-62 \\
-49 \\
-26 \\
-21 \\
-19 \\
-21 \\
-19 \\
-28 \\
-22\end{array}$ & $\begin{array}{l}-78 \\
-52 \\
-36 \\
-26 \\
-28 \\
-26 \\
-24 \\
-24 \\
-17 \\
-21\end{array}$ & $\begin{array}{r}-3725 \\
-2517 \\
-1871 \\
-1140 \\
-1080 \\
-983 \\
-991 \\
-988 \\
-1035 \\
-985\end{array}$ & $\begin{array}{r}-755 \\
-390 \\
-278 \\
-333 \\
-384 \\
-212 \\
-70 \\
923 \\
988 \\
1011\end{array}$ & $\begin{array}{r}-161 \\
-127 \\
-181 \\
0 \\
94 \\
96 \\
32 \\
58 \\
-157 \\
-7\end{array}$ & $\begin{array}{r}-747 \\
-383 \\
-257 \\
-333 \\
-372 \\
-200 \\
-69 \\
924 \\
1000 \\
1011\end{array}$ & $\begin{array}{r}-3734 \\
-2525 \\
-1891 \\
-1140 \\
-1092 \\
-994 \\
-992 \\
-990 \\
-1047 \\
-985\end{array}$ \\
\hline $\begin{array}{l}0315 C-B \\
0315 C-C \\
0315 C-D \\
0315 C-E \\
0315 C-E \\
0315 C-B * \\
0315 C-R \\
0315 C-L \\
0315 C-A \\
0315 C-P\end{array}$ & $\begin{array}{r}5 \\
9 \\
14 \\
26 \\
28 \\
0 \\
38 \\
41 \\
45 \\
45\end{array}$ & $\begin{array}{l}-33 \\
-21 \\
-21 \\
-19 \\
-28 \\
-14 \\
-16 \\
-16 \\
-19 \\
-26\end{array}$ & $\begin{array}{l}-26 \\
-17 \\
-19 \\
-14 \\
-14 \\
-16 \\
-19 \\
-21 \\
-24 \\
-19\end{array}$ & $\begin{array}{r}-1308 \\
-844 \\
-902 \\
-758 \\
-969 \\
-667 \\
-815 \\
-865 \\
-979 \\
-1028\end{array}$ & $\begin{array}{r}-250 \\
31 \\
156 \\
555 \\
563 \\
-200 \\
902 \\
959 \\
1064 \\
1050\end{array}$ & $\begin{array}{r}-95 \\
-63 \\
-32 \\
-63 \\
-190 \\
32 \\
30 \\
63 \\
64 \\
-93\end{array}$ & $\begin{array}{r}-242 \\
36 \\
157 \\
558 \\
586 \\
-198 \\
902 \\
962 \\
1066 \\
1054\end{array}$ & $\begin{array}{r}-1317 \\
-849 \\
-903 \\
-761 \\
-993 \\
-669 \\
-815 \\
-868 \\
-981 \\
-1033\end{array}$ \\
\hline $\begin{array}{l}\text { I315n-B } \\
\text { I315n-C } \\
\text { I315n-D } \\
\text { I315n-B } \\
\text { I315n-F } \\
\text { I315n-M* }\end{array}$ & $\begin{array}{r}5 \\
-36 \\
-28 \\
-19 \\
-12 \\
-3\end{array}$ & $\begin{array}{r}-79 \\
-52 \\
-33 \\
-19 \\
-12 \\
0\end{array}$ & $\begin{array}{l}-81 \\
-52 \\
-31 \\
-19 \\
-14 \\
-282\end{array}$ & $\begin{array}{r}-3521 \\
-2263 \\
-1376 \\
-808 \\
-554 \\
-6190\end{array}$ & $\begin{array}{r}-907 \\
-1748 \\
-1267 \\
-808 \\
-517 \\
-1953\end{array}$ & $\begin{array}{r}31 \\
-1 \\
-32 \\
1 \\
33 \\
3765\end{array}$ & $\begin{array}{r}-906 \\
-1748 \\
-1259 \\
-807 \\
-498 \\
248\end{array}$ & $\begin{array}{r}-3522 \\
-2263 \\
-1385 \\
-809 \\
-573 \\
-8392\end{array}$ \\
\hline $\begin{array}{l}0315 n-B \\
0315 \pi-C \\
0315 \pi-D \\
0315 n-E \\
0315 n-E \\
0315 n-G \\
0315 \pi-B \\
0315 \pi-K \\
03151-R\end{array}$ & $\begin{array}{r}13 \\
5 \\
-11 \\
-4 \\
-9 \\
-6 \\
-9 \\
-4 \\
-39\end{array}$ & $\begin{array}{r}-31 \\
14 \\
14 \\
12 \\
8 \\
5 \\
3 \\
-2 \\
-2\end{array}$ & $\begin{array}{r}-21 \\
19 \\
19 \\
12 \\
10 \\
5 \\
3 \\
-4 \\
-2\end{array}$ & $\begin{array}{r}-1154 \\
731 \\
752 \\
531 \\
392 \\
238 \\
131 \\
-124 \\
-34\end{array}$ & $\begin{array}{r}42 \\
368 \\
-112 \\
31 \\
-147 \\
-123 \\
-226 \\
-164 \\
-1187\end{array}$ & $\begin{array}{r}-124 \\
-62 \\
-66 \\
-2 \\
-30 \\
2 \\
0 \\
29 \\
0\end{array}$ & $\begin{array}{r}55 \\
741 \\
757 \\
531 \\
394 \\
238 \\
131 \\
-109 \\
-34\end{array}$ & $\begin{array}{r}-1167 \\
358 \\
-117 \\
31 \\
-149 \\
-123 \\
-226 \\
-179 \\
-1187\end{array}$ \\
\hline
\end{tabular}

STRESSES PRIN STRESSBS

TRAMS$$
\text { - }
$$ 
Fable A.9. Out-of-plene ganent Iosdirg, Y, on sylinder

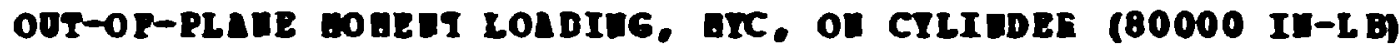

aICRC-STEATU

-

DOSETTE GAGEI GAGẼ GLEE3

\begin{tabular}{|c|c|c|c|c|c|c|c|c|}
\hline \multirow[b]{2}{*}{ MOSETTE } & \multicolumn{3}{|c|}{ GICRC-STENTE } & \multicolumn{3}{|c|}{ STRESSES } & \multicolumn{2}{|c|}{ PRIE STRESSES } \\
\hline & & DG F & & $2 \mathbf{2}$ & LOIS & SEERE & SIGaX & SIGn \\
\hline $\begin{array}{l}I-0-C-E \\
I-0-C-I \\
I-0-C-I \\
I-0-C-J \\
I-0-C-I \\
I-0-C-I \\
I-0-C-I \\
I-0-C-D \\
I-0-C-S\end{array}$ & $\begin{array}{r}0 \\
0 \\
5 \\
5 \\
7 \\
10 \\
12 \\
-122 \\
12 \\
12 \\
15\end{array}$ & $\begin{array}{l}-19 \\
-17 \\
-17 \\
-14 \\
-21 \\
-24 \\
-12 \\
-5 \\
-9 \\
-9 \\
-2\end{array}$ & $\begin{array}{l}-14 \\
-19 \\
-19 \\
-21 \\
-17 \\
-12 \\
-24 \\
-21 \\
-24 \\
-18 \\
-12\end{array}$ & $\begin{array}{l}-734 \\
-786 \\
-792 \\
-792 \\
-847 \\
-797 \\
-799 \\
-529 \\
-733 \\
-820 \\
-330\end{array}$ & $\begin{array}{r}-220 \\
-236 \\
-94 \\
-94 \\
-39 \\
47 \\
118 \\
-3821 \\
150 \\
185 \\
350\end{array}$ & $\begin{array}{r}-64 \\
32 \\
32 \\
95 \\
-64 \\
-159 \\
159 \\
158 \\
192 \\
125 \\
141\end{array}$ & $\begin{array}{r}-212 \\
-234 \\
-93 \\
-.82 \\
-34 \\
76 \\
145 \\
-522 \\
190 \\
204 \\
378\end{array}$ & $\begin{array}{l}-742 \\
-788 \\
-793 \\
-804 \\
-852 \\
-826 \\
-826 \\
-3828 \\
-773 \\
-639 \\
-358\end{array}$ \\
\hline $\begin{array}{l}0-0-C-B \\
0-0-C-C \\
0-0-C-D \\
0-0-C-E \\
0-0-C-P \\
0-0-C-E \\
0-0-C-J \\
0-0-C-C \\
0-0-C-I \\
0-0-C-B \\
0-0-C-B \\
0-0-C-S\end{array}$ & $\begin{array}{r}9 \\
7 \\
9 \\
9 \\
9 \\
12 \\
11 \\
16 \\
14 \\
14 \\
16 \\
19\end{array}$ & $\begin{array}{l}12 \\
14 \\
16 \\
19 \\
19 \\
16 \\
16 \\
16 \\
16 \\
16 \\
14 \\
7\end{array}$ & $\begin{array}{l}12 \\
16 \\
19 \\
21 \\
21 \\
23 \\
23 \\
21 \\
21 \\
21 \\
19 \\
16\end{array}$ & $\begin{array}{l}505 \\
659 \\
762 \\
862 \\
866 \\
861 \\
860 \\
802 \\
807 \\
806 \\
700 \\
488\end{array}$ & $\begin{array}{l}130 \\
106 \\
505 \\
534 \\
536 \\
605 \\
600 \\
728 \\
657 \\
659 \\
698 \\
702\end{array}$ & $\begin{array}{r}1 \\
-32 \\
-30 \\
-29 \\
-32 \\
-94 \\
-92 \\
-63 \\
-64 \\
-64 \\
-62 \\
-127\end{array}$ & $\begin{array}{l}505 \\
663 \\
765 \\
865 \\
869 \\
892 \\
889 \\
838 \\
830 \\
830 \\
761 \\
761\end{array}$ & $\begin{array}{l}430 \\
402 \\
501 \\
532 \\
531 \\
574 \\
571 \\
691 \\
633 \\
635 \\
637 \\
430\end{array}$ \\
\hline $\begin{array}{l}I-0-I-B \\
I-0-I-C \\
I-0-I-D \\
I-0-I-E \\
I-0-I-I \\
I-0-I-I\end{array}$ & $\begin{array}{r}-29 \\
-12 \\
-5 \\
-5 \\
-5 \\
0\end{array}$ & $\begin{array}{r}-7 \\
2 \\
2 \\
2 \\
2 \\
0\end{array}$ & $\begin{array}{r}-10 \\
5 \\
5 \\
2 \\
2 \\
0\end{array}$ & $\begin{array}{r}-337 \\
171 \\
163 \\
111 \\
111 \\
0\end{array}$ & $\begin{array}{r}-963 \\
-308 \\
-95 \\
-111 \\
-111 \\
0\end{array}$ & $\begin{array}{r}32 \\
-32 \\
-32 \\
0 \\
0 \\
0\end{array}$ & $\begin{array}{r}-335 \\
173 \\
167 \\
111 \\
111 \\
0\end{array}$ & $\begin{array}{r}-965 \\
-310 \\
-99 \\
-111 \\
-111 \\
0\end{array}$ \\
\hline 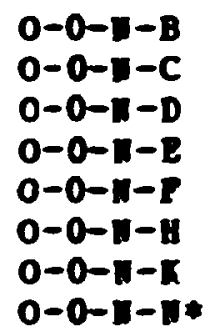 & $\begin{array}{r}-10 \\
-15 \\
-12 \\
-10 \\
-7 \\
-5 \\
2 \\
2\end{array}$ & $\begin{array}{l}9 \\
4 \\
2 \\
2 \\
0 \\
C \\
0 \\
2\end{array}$ & $\begin{array}{r}9 \\
0 \\
0 \\
0 \\
0 \\
0 \\
0 \\
-41\end{array}$ & $\begin{array}{r}417 \\
207 \\
54 \\
54 \\
-3 \\
-2 \\
-8 \\
-868\end{array}$ & $\begin{array}{l}-167 \\
-375 \\
-349 \\
-277 \\
-224 \\
-150 \\
56 \\
-197\end{array}$ & $\begin{array}{r}-1 \\
-1 \\
30 \\
31 \\
1 \\
1 \\
-1 \\
580\end{array}$ & $\begin{array}{r}417 \\
207 \\
56 \\
57 \\
-3 \\
-2 \\
56 \\
138\end{array}$ & $\begin{array}{r}-167 \\
-375 \\
-351 \\
-280 \\
-224 \\
-150 \\
-8 \\
-1203\end{array}$ \\
\hline
\end{tabular}

PRII STRESSES

STRESSES

\section{- -}

Trans 


\begin{tabular}{|c|c|c|c|c|c|c|c|c|}
\hline \multirow[b]{2}{*}{ OSET TE } & \multicolumn{3}{|c|}{ aICaO-STEArn } & \multicolumn{3}{|c|}{ STRESSES } & \multicolumn{2}{|c|}{ PRI: STRESSES } \\
\hline & $\mathbf{A G E}$ & GAG & & & LOIG & FEEAR & GHX & I GA I \\
\hline $\begin{array}{l}D C-B \\
D C-C= \\
D C-D \\
D C-E \\
D C-F \\
D C-B\end{array}$ & $\begin{array}{r}-5 \\
-12 \\
-12 \\
-14 \\
-14 \\
77\end{array}$ & $\begin{array}{r}-34 \\
-34 \\
-34 \\
-36 \\
-5 \\
-122\end{array}$ & $\begin{array}{r}-26 \\
0 \\
-22 \\
-22 \\
-24 \\
-120\end{array}$ & $\begin{array}{r}-1310 \\
-723 \\
-1197 \\
-1247 \\
-616 \\
-5397\end{array}$ & $\begin{array}{r}-537 \\
-576 \\
-718 \\
-805 \\
-616 \\
679\end{array}$ & $\begin{array}{r}-96 \\
-447 \\
-159 \\
-191 \\
255 \\
-32\end{array}$ & $\begin{array}{r}-525 \\
-197 \\
-670 \\
-734 \\
-360 \\
679\end{array}$ & $\begin{array}{r}-1322 \\
-1102 \\
-1245 \\
-1318 \\
-871 \\
-5397\end{array}$ \\
\hline $\begin{array}{l}D C-B \\
D C-C \\
D C-D \\
D C-B \\
D C-B \\
D C-B\end{array}$ & $\begin{array}{l}16 \\
22 \\
26 \\
29 \\
33 \\
19\end{array}$ & $\begin{array}{r}9 \\
5 \\
-4 \\
-9 \\
-12 \\
-1 \leq 1\end{array}$ & $\begin{array}{r}14 \\
0 \\
-9 \\
-14 \\
-24 \\
-158\end{array}$ & $\begin{array}{r}488 \\
91 \\
-324 \\
-543 \\
-809 \\
-6817\end{array}$ & $\begin{array}{r}632 \\
678 \\
697 \\
702 \\
761 \\
-1465\end{array}$ & $\begin{array}{r}-66 \\
64 \\
59 \\
64 \\
159 \\
85\end{array}$ & $\begin{array}{r}658 \\
685 \\
700 \\
705 \\
777 \\
-1464\end{array}$ & $\begin{array}{r}463 \\
84 \\
-327 \\
-546 \\
-825 \\
-6819\end{array}$ \\
\hline 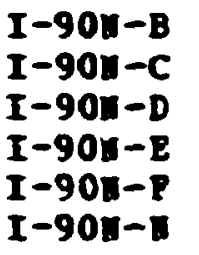 & $\begin{array}{r}-60 \\
5 \\
16 \\
14 \\
-24 \\
-19\end{array}$ & $\begin{array}{r}0 \\
5 \\
2 \\
-2 \\
-12 \\
-14\end{array}$ & $\begin{array}{r}-14 \\
5 \\
7 \\
2 \\
12 \\
-11\end{array}$ & $\begin{array}{r}-248 \\
204 \\
109 \\
-18 \\
26 \\
-536\end{array}$ & $\begin{array}{r}-1862 \\
204 \\
550 \\
417 \\
-708 \\
-721\end{array}$ & $\begin{array}{r}191 \\
0 \\
-65 \\
-65 \\
-318 \\
-32\end{array}$ & $\begin{array}{r}-226 \\
204 \\
561 \\
426 \\
145 \\
-531\end{array}$ & $\begin{array}{r}-1884 \\
204 \\
178 \\
-27 \\
-826 \\
-726\end{array}$ \\
\hline $\begin{array}{l}0-90 n-B \\
0-90 N-C \\
0-90 N-D \\
0-90 n-Z \\
0-90 x-P \\
0-00 x-P\end{array}$ & $\begin{array}{r}22 \\
3 \\
3 \\
5 \\
5 \\
-4\end{array}$ & $\begin{array}{r}29 \\
7 \\
3 \\
0 \\
0 \\
-2\end{array}$ & $\begin{array}{r}29 \\
10 \\
3 \\
3 \\
3 \\
0\end{array}$ & $\begin{array}{r}1239 \\
376 \\
116 \\
59 \\
60 \\
-33\end{array}$ & $\begin{array}{r}1024 \\
193 \\
117 \\
176 \\
172 \\
-143\end{array}$ & $\begin{array}{r}0 \\
-33 \\
-2 \\
-31 \\
-30 \\
-31\end{array}$ & $\begin{array}{r}1239 \\
381 \\
118 \\
184 \\
179 \\
-25\end{array}$ & $\begin{array}{r}1024 \\
187 \\
115 \\
52 \\
52 \\
-151\end{array}$ \\
\hline
\end{tabular}


Table i.9 (continied)

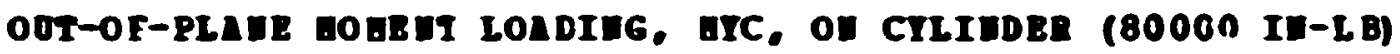

EICBO-STENI"
STRESSES

$-\infty-0-0$

PRII STRESSES

TR:US

LON6

ROSETTE GAGEI

I $180 \mathrm{C}-\mathrm{B}$

$1180 C-C$

I $180 C-D$

I180C-S

I180C-?

I180C-S

$0180 \mathrm{C}-\mathrm{B}$

$018 x-c$

$0180 C-D$

$0180 C-E$

$0180 C-1$

$0180 c-5$

I180:-B

I 180:-C

I 180:-D

I 1804-

I 1804-:

I190"-1

01801-B -14

$01804-C \quad-17$

$01801-D \quad-14$

$01801-\mathrm{E} \quad-12$

$0180 \mathrm{y}-\mathrm{E} \quad-7$

01801-1

$\begin{array}{rrr}0 & -17 & -31 \\ -2 & -9 & -28 \\ 0 & -12 & -26 \\ 5 & -14 & -28 \\ 2 & -17 & -28 \\ 17 & -\equiv 1 & -26\end{array}$

$-1037$

$-827$

$-829$

$-938$

$-987$

$-1262$

i1

$$
\begin{array}{r}
-24 \\
-12 \\
-3 \\
-3 \\
-9 \\
2
\end{array}
$$

$$
\begin{array}{r}
-5 \\
2 \\
4 \\
2 \\
2
\end{array}
$$$$
\begin{array}{r}
-5 \\
2 \\
2 \\
2
\end{array}
$$

$-149$

$\begin{array}{ll}2 & 12 \\ 5 & \\ 0 & \\ 2 & -2 \\ 0 & -2 \\ 2 & \end{array}$

472
630

679

782

826

945

260

302

302

114

83

-

$$
-311
$$

$-319$

$-249$

$-140$

$-225$

i 17

291

339

350

455

533

141

-773
-290

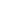

$-249$

86

$\begin{array}{rr}323 & -329 \\ 227 & -431 \\ 68 & -408 \\ 13 & -353 \\ -44 & -227 \\ 102 & 102\end{array}$
SHEAR SIGar SIGa

$\begin{array}{lll}189 & -265 & -1083\end{array}$

$\begin{array}{lll}251 & -215 & -930\end{array}$

$\begin{array}{lll}189 & -193-885\end{array}$

$\begin{array}{lll}189 & -98 & -980\end{array}$

$157-194-1018$

$\begin{array}{lll}-63 & 119-1265\end{array}$

$$
\begin{aligned}
& -221 \\
& -191 \\
& -158 \\
& -159 \\
& -127
\end{aligned}
$$

0

620

724

743

847

873

946

-34
-96

$-148$

277

315

316

$114-249$

$-65$

$-2$

37

82

$352-353$

227

$-431$

$-410$

$-363$

24

$-233$ 
Table A.9 (cortinued)

\begin{tabular}{|c|c|c|c|c|c|c|c|c|}
\hline \multirow[b]{2}{*}{ BOSET TE } & \multicolumn{3}{|c|}{ GICBO-SIEAIU } & \multicolumn{3}{|c|}{ STRESSES } & \multicolumn{2}{|c|}{ PRIY STRESSES } \\
\hline & :AGEI & AGE2 & GAGE3 & RAUS & LONG & ;A E $\triangle R$ & $5 \operatorname{Igax}$ & SI Ga \\
\hline 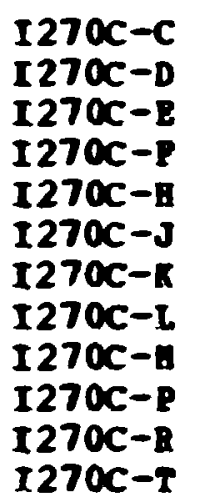 & $\begin{array}{l}-20 \\
-22 \\
-25 \\
-25 \\
-25 \\
-25 \\
-22 \\
-24 \\
-15 \\
-19 \\
-22 \\
-22\end{array}$ & $\begin{array}{r}23 \\
28 \\
28 \\
33 \\
45 \\
61 \\
69 \\
51 \\
67 \\
133 \\
152 \\
7\end{array}$ & $\begin{array}{r}30 \\
35 \\
35 \\
40 \\
42 \\
57 \\
66 \\
88 \\
107 \\
121 \\
132 \\
2\end{array}$ & $\begin{array}{l}1197 \\
1409 \\
1409 \\
1620 \\
1932 \\
2571 \\
2991 \\
3959 \\
4492 \\
5617 \\
5813 \\
234\end{array}$ & $\begin{array}{r}-234 \\
-241 \\
-312 \\
-250 \\
-159 \\
35 \\
242 \\
458 \\
895 \\
1115 \\
1097 \\
-576\end{array}$ & $\begin{array}{r}-96 \\
-98 \\
-96 \\
-96 \\
32 \\
94 \\
30 \\
45 \\
-129 \\
162 \\
0 \\
64\end{array}$ & $\begin{array}{l}1203 \\
1414 \\
1415 \\
1625 \\
1932 \\
2575 \\
2991 \\
3960 \\
4497 \\
5623 \\
5813 \\
239\end{array}$ & $\begin{array}{r}-240 \\
-247 \\
-318 \\
-255 \\
-160 \\
32 \\
241 \\
458 \\
890 \\
1109 \\
1097 \\
-581\end{array}$ \\
\hline $\begin{array}{l}270 C-B \\
270 C-C \\
270 C-D \\
270 C-E \\
270 C-F \\
270 C-B \\
270 C-J \\
270 C-K \\
270 C-L \\
270 C-A \\
270 C-\mathrm{P} \\
272 C-R \\
270 C-T\end{array}$ & $\begin{array}{r}12 \\
12 \\
10 \\
7 \\
3 \\
-5 \\
-14 \\
-21 \\
-38 \\
-52 \\
-66 \\
-64 \\
15\end{array}$ & $\begin{array}{l}55 \\
45 \\
48 \\
48 \\
45 \\
58 \\
64 \\
69 \\
83 \\
58 \\
114 \\
122 \\
14\end{array}$ & $\begin{array}{r}48 \\
36 \\
36 \\
38 \\
36 \\
145 \\
55 \\
64 \\
91 \\
95 \\
107 \\
122 \\
0\end{array}$ & $\begin{array}{l}2233 \\
1772 \\
1826 \\
1882 \\
1782 \\
2209 \\
2635 \\
2958 \\
3867 \\
4301 \\
4945 \\
5412 \\
303\end{array}$ & $\begin{array}{r}1026 \\
894 \\
839 \\
785 \\
612 \\
527 \\
371 \\
252 \\
25 \\
-273 \\
-507 \\
-297 \\
529\end{array}$ & $\begin{array}{r}95 \\
127 \\
157 \\
126 \\
127 \\
126 \\
128 \\
63 \\
-94 \\
31 \\
95 \\
0 \\
193\end{array}$ & $\begin{array}{r}2241 \\
1790 \\
1851 \\
1896 \\
1796 \\
2218 \\
2647 \\
2960 \\
3869 \\
4301 \\
4946 \\
5412 \\
639\end{array}$ & $\begin{array}{r}1018 \\
876 \\
815 \\
770 \\
598 \\
517 \\
364 \\
250 \\
22 \\
-273 \\
-508 \\
-297 \\
192\end{array}$ \\
\hline $\begin{array}{l}I 270 \pi-B \\
I 270 \pi-C \\
I 270 \pi-D \\
I 270 \pi-B \\
I 270 \pi-P\end{array}$ & $\begin{array}{r}-59 \\
17 \\
27 \\
17 \\
8\end{array}$ & $\begin{array}{r}41 \\
33 \\
17 \\
7 \\
-\frac{2}{2}\end{array}$ & $\begin{array}{l}34 \\
31 \\
17 \\
7 \\
0\end{array}$ & $\begin{array}{r}1702 \\
1404 \\
710 \\
301 \\
-61\end{array}$ & $\begin{array}{r}-1269 \\
930 \\
1008 \\
600 \\
215\end{array}$ & $\begin{array}{r}96 \\
30 \\
0 \\
-1 \\
-32\end{array}$ & $\begin{array}{r}1705 \\
1406 \\
1008 \\
600 \\
219\end{array}$ & $\begin{array}{r}-1272 \\
928 \\
710 \\
301 \\
-65\end{array}$ \\
\hline 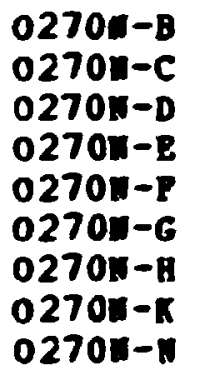 & $\begin{array}{r}9 \\
-3 \\
5 \\
12 \\
9 \\
10 \\
9 \\
2 \\
-2\end{array}$ & $\begin{array}{r}50 \\
5 \\
-5 \\
-5 \\
-2\end{array}$ & $\begin{array}{r}38 \\
5 \\
-5 \\
-5 \\
0 \\
2 \\
5 \\
2 \\
0\end{array}$ & $\begin{array}{r}1909 \\
204 \\
-215 \\
-222 \\
-65 \\
95 \\
146 \\
100 \\
1\end{array}$ & $\begin{array}{r}847 \\
-16 \\
77 \\
290 \\
265 \\
314 \\
328 \\
100 \\
-73\end{array}$ & $\begin{array}{r}156 \\
0 \\
0 \\
0 \\
-31 \\
0 \\
-32 \\
0 \\
0\end{array}$ & $\begin{array}{r}1932 \\
204 \\
77 \\
290 \\
263 \\
314 \\
334 \\
100 \\
1\end{array}$ & $\begin{array}{r}824 \\
-16 \\
-215 \\
-222 \\
68 \\
95 \\
140 \\
100 \\
-73\end{array}$ \\
\hline
\end{tabular}


OOT-OF-PLANE NOAEST LONDIMG, MTC, OI CTLIMDER (80000 IV-LB)

GICRO-STEAI"
BOSETTE GAGEI GAGE2 GAGE3

\begin{tabular}{|c|c|c|c|c|c|c|c|c|}
\hline $\begin{array}{l}\text { I } 315 C-B \\
1315 C-C \\
1315 C-D \\
1315 C-P \\
1315 C-8 \\
1315 C-A \\
1315 C-R \\
1315 C-L \\
1315 C-1 \\
1315 C-P\end{array}$ & $\begin{array}{l}-9 \\
-7 \\
-5 \\
-9 \\
-7 \\
-4 \\
3 \\
31 \\
52 \\
62\end{array}$ & $\begin{array}{r}26 \\
31 \\
34 \\
12 \\
15 \\
20 \\
29 \\
82 \\
94 \\
125\end{array}$ & $\begin{array}{l}-23 \\
-33 \\
-33 \\
-4 \\
-14 \\
-14 \\
-14 \\
-19 \\
-22 \\
-15\end{array}$ & $\begin{array}{r}78 \\
-28 \\
16 \\
185 \\
30 \\
129 \\
329 \\
1334 \\
1539 \\
2343\end{array}$ & $\begin{array}{r}-258 \\
-215 \\
-139 \\
-220 \\
-193 \\
-91 \\
186 \\
1333 \\
2033 \\
2553\end{array}$ & $\begin{array}{r}665 \\
859 \\
888 \\
223 \\
380 \\
445 \\
572 \\
1346 \\
1545 \\
1856\end{array}$ & $\begin{array}{r}j 96 \\
742 \\
830 \\
283 \\
315 \\
478 \\
834 \\
2680 \\
3351 \\
4307\end{array}$ & $\begin{array}{r}-776 \\
-986 \\
-953 \\
-319 \\
-478 \\
-440 \\
-319 \\
-13 \\
221 \\
589\end{array}$ \\
\hline $\begin{array}{l}315 C-B \\
315 C-C \\
315 C-D \\
315 C-E \\
315 C-P \\
315 C-A \\
15 C-R \\
15 C-L \\
315 C-A \\
315 C-P\end{array}$ & $\begin{array}{l}7 \\
12 \\
15 \\
14 \\
19 \\
21 \\
26 \\
26 \\
31 \\
33\end{array}$ & $\begin{array}{r}15 \\
14 \\
12 \\
12 \\
3 \\
7 \\
-2 \\
-26 \\
-26 \\
-35\end{array}$ & $\begin{array}{r}26 \\
29 \\
43 \\
45 \\
50 \\
52 \\
69 \\
88 \\
102 \\
123\end{array}$ & $\begin{array}{r}891 \\
938 \\
1192 \\
1245 \\
1139 \\
1282 \\
1433 \\
1330 \\
1636 \\
1895\end{array}$ & $\begin{array}{r}492 \\
646 \\
793 \\
805 \\
919 \\
1027 \\
1214 \\
1184 \\
1418 \\
1566\end{array}$ & $\begin{array}{r}-158 \\
-191 \\
-411 \\
-443 \\
-629 \\
-601 \\
-949 \\
-1597 \\
-1707 \\
-2117\end{array}$ & $\begin{array}{r}946 \\
1032 \\
1449 \\
1520 \\
1667 \\
1768 \\
2279 \\
2776 \\
3237 \\
3854\end{array}$ & $\begin{array}{r}437 \\
552 \\
536 \\
531 \\
391 \\
540 \\
369 \\
-262 \\
-183 \\
-393\end{array}$ \\
\hline $\begin{array}{l}315 n-B \\
315 n-C \\
315 x-D \\
315 n-B \\
315 x-B \\
315 \pi-1\end{array}$ & $\begin{array}{r}-43 \\
7 \\
12 \\
7 \\
2 \\
0\end{array}$ & $\begin{array}{r}21 \\
12 \\
5 \\
0 \\
0 \\
-2\end{array}$ & $\begin{array}{r}5 \\
14 \\
7 \\
0 \\
0 \\
0\end{array}$ & $\begin{array}{l}622 \\
562 \\
239 \\
-19 \\
-14 \\
-52\end{array}$ & $\begin{array}{r}-1111 \\
378 \\
425 \\
208 \\
61 \\
-16\end{array}$ & $\begin{array}{r}224 \\
-31 \\
-32 \\
-1 \\
-1 \\
-31\end{array}$ & $\begin{array}{r}650 \\
567 \\
430 \\
202 \\
61 \\
3\end{array}$ & $\begin{array}{r}-1140 \\
373 \\
234 \\
-19 \\
-14 \\
-70\end{array}$ \\
\hline 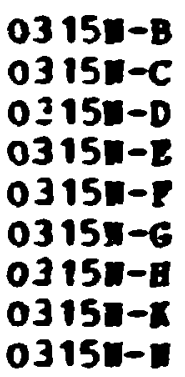 & $\begin{array}{r}-5 \\
-17 \\
-9 \\
-4 \\
1 \\
-2 \\
-2 \\
-2 \\
-41\end{array}$ & $\begin{array}{r}19 \\
5 \\
3 \\
2 \\
1 \\
3 \\
3 \\
1 \\
-2\end{array}$ & $\begin{array}{r}33 \\
2 \\
-9 \\
-9 \\
-9 \\
-9 \\
-7 \\
-2 \\
-4\end{array}$ & $\begin{array}{r}1154 \\
177 \\
-124 \\
-142 \\
-182 \\
-122 \\
-81 \\
-20 \\
-80\end{array}$ & $\begin{array}{r}209 \\
-444 \\
-302 \\
-170 \\
-31 \\
-85 \\
-75 \\
-59 \\
-1252\end{array}$ & $\begin{array}{r}-189 \\
32 \\
150 \\
151 \\
127 \\
160 \\
124 \\
29 \\
31\end{array}$ & $\begin{array}{r}1191 \\
178 \\
-39 \\
-4 \\
41 \\
57 \\
46 \\
-4 \\
-79\end{array}$ & $\begin{array}{r}173 \\
-445 \\
-388 \\
-308 \\
-254 \\
-264 \\
-202 \\
-74 \\
-1253\end{array}$ \\
\hline
\end{tabular}

STRESSES

PRII STRESSES

TRAUS

Lome

SBEAR

SIGHX SIGLI

-

-

--

776

986

319

478

319

$-13$

221

37

31

391

369

$-262$

183

140

13

$-19$

$-14$

173

445

$-388$

$-254$

264

202
-74

1253 
Table A.10. In-plane moment loading, $\mathrm{K}_{\mathrm{ZC}}$, on cylinder

\begin{tabular}{|c|c|c|c|c|c|c|c|c|}
\hline \multirow[b]{2}{*}{ ROSETTE } & \multicolumn{3}{|c|}{ MICRO-STEAIM } & \multicolumn{3}{|c|}{ STRE SSES } & \multicolumn{2}{|c|}{ PRIA STRESSES } \\
\hline & GAGE 1 & GMGE2 & GXGE3 & PRAnS & LONG & SHELR & SIG:X & SIGRN \\
\hline $\begin{array}{l}-0-C-C \\
-0-C-D \\
-0-C-E \\
-0-C-F \\
-0-C-F \\
-0-C-J \\
-0-C-R \\
-0-C-I \\
-0-C-A \\
-0-C-P \\
-0-C-S\end{array}$ & $\begin{array}{r}1 \\
-21 \\
-47 \\
-69 \\
-118 \\
-149 \\
-161 \\
-144 \\
-173 \\
-178 \\
-180\end{array}$ & $\begin{array}{r}80 \\
44 \\
32 \\
22 \\
1 \\
3 \\
3 \\
1 \\
3 \\
18 \\
1 E\end{array}$ & $\begin{array}{r}58 \\
25 \\
15 \\
10 \\
15 \\
5 \\
8 \\
18 \\
13 \\
4 \\
4\end{array}$ & $\begin{array}{l}3025 \\
1523 \\
1079 \\
780 \\
477 \\
363 \\
431 \\
569 \\
539 \\
571 \\
677\end{array}$ & $\begin{array}{r}928 \\
-169 \\
-1093 \\
-1821 \\
-3405 \\
-4372 \\
-4708 \\
-4146 \\
-5036 \\
-5137 \\
-5191\end{array}$ & $\begin{array}{r}287 \\
255 \\
222 \\
157 \\
-191 \\
-34 \\
-71 \\
-224 \\
-125 \\
186 \\
189\end{array}$ & $\begin{array}{l}3053 \\
1560 \\
1102 \\
790 \\
487 \\
363 \\
432 \\
580 \\
542 \\
677 \\
683\end{array}$ & $\begin{array}{r}889 \\
-236 \\
-1115 \\
-1831 \\
-3415 \\
-4372 \\
-4709 \\
-4157 \\
-5039 \\
-5143 \\
-5197\end{array}$ \\
\hline $\begin{array}{l}-0-C-B \\
-0-C-C \\
-0-C-D \\
-0-C-E \\
-0-C-P \\
-0-C-A \\
-0-C-J \\
-0-C-R \\
-0-C-I \\
-0-C-A \\
-0-C-P \\
-0-C-S\end{array}$ & $\begin{array}{r}-45 \\
-71 \\
-97 \\
-104 \\
-121 \\
-140 \\
-164 \\
-168 \\
-183 \\
-180 \\
-193 \\
-192\end{array}$ & $\begin{array}{l}5 \\
-17 \\
-33 \\
-36 \\
-31 \\
-33 \\
-19 \\
-24 \\
-17 \\
-19 \\
-19 \\
-24\end{array}$ & $\begin{array}{l}-2 \\
-26 \\
-36 \\
-33 \\
-38 \\
-28 \\
-31 \\
-19 \\
-24 \\
-17 \\
-24 \\
-14\end{array}$ & $\begin{array}{r}101 \\
-859 \\
-1404 \\
-1395 \\
-1378 \\
-1200 \\
-913 \\
-752 \\
-684 \\
-582 \\
-737 \\
-522\end{array}$ & $\begin{array}{l}-1324 \\
-2392 \\
-3337 \\
-3548 \\
-4040 \\
-4557 \\
-5182 \\
-5276 \\
-5692 \\
-5581 \\
-5699 \\
-5948\end{array}$ & $\begin{array}{r}94 \\
126 \\
32 \\
-32 \\
95 \\
-63 \\
157 \\
-63 \\
95 \\
-31 \\
53 \\
-126\end{array}$ & $\begin{array}{r}107 \\
-849 \\
-1403 \\
-1394 \\
-1375 \\
-1199 \\
-907 \\
-751 \\
-683 \\
-582 \\
-736 \\
-619\end{array}$ & $\begin{array}{l}-1327 \\
-2402 \\
-3338 \\
-5348 \\
-4044 \\
-4558 \\
-5188 \\
-5277 \\
-5684 \\
-5581 \\
-5699 \\
-5951\end{array}$ \\
\hline $\begin{array}{l}I-0-I-B \\
I-0-N-C \\
I-0-N-D \\
I-0-M-B \\
I-0-n-P \\
I-C-N-W *\end{array}$ & $\begin{array}{r}74 \\
62 \\
38 \\
29 \\
29 \\
0\end{array}$ & $\begin{array}{r}134 \\
84 \\
60 \\
50 \\
38 \\
3\end{array}$ & $\begin{array}{r}122 \\
74 \\
55 \\
50 \\
46 \\
3\end{array}$ & $\begin{array}{r}5554 \\
3407 \\
2485 \\
2181 \\
1813 \\
110\end{array}$ & $\begin{array}{r}3897 \\
2894 \\
1899 \\
1520 \\
1408 \\
36\end{array}$ & $\begin{array}{r}159 \\
128 \\
54 \\
-1 \\
-95 \\
0\end{array}$ & $\begin{array}{l}5569 \\
3433 \\
2492 \\
2191 \\
1835 \\
110\end{array}$ & $\begin{array}{r}3882 \\
2864 \\
1892 \\
1520 \\
1387 \\
36\end{array}$ \\
\hline 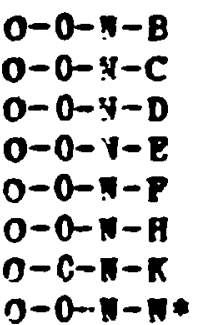 & $\begin{array}{r}7 \\
45 \\
52 \\
52 \\
47 \\
40 \\
21 \\
2\end{array}$ & $\begin{array}{r}-21 \\
-52 \\
-43 \\
-36 \\
-28 \\
-3 \\
7 \\
2\end{array}$ & $\begin{array}{l}-21 \\
-45 \\
-40 \\
-31 \\
-26 \\
-12 \\
9 \\
244\end{array}$ & $\begin{array}{r}-945 \\
-2184 \\
-1889 \\
-1516 \\
-1250 \\
-512 \\
341 \\
5422\end{array}$ & $\begin{array}{r}-69 \\
698 \\
1002 \\
1111 \\
1049 \\
1056 \\
744 \\
1698\end{array}$ & $\begin{array}{r}0 \\
-94 \\
-32 \\
-63 \\
-32 \\
32 \\
-32 \\
-3225\end{array}$ & $\begin{array}{r}-69 \\
701 \\
1002 \\
1113 \\
1049 \\
1057 \\
747 \\
7294\end{array}$ & $\begin{array}{r}-945 \\
-2198 \\
-1880 \\
-1517 \\
-1250 \\
-513 \\
339 \\
-164\end{array}$ \\
\hline
\end{tabular}




\begin{tabular}{|c|c|c|c|c|c|c|c|c|}
\hline \multirow[b]{2}{*}{ IOSETTE } & \multicolumn{3}{|c|}{ MICRO-STEATY } & \multicolumn{3}{|c|}{ STRESSES } & \multicolumn{2}{|c|}{ PRIA STRESSES } \\
\hline & GAGE1 & GAGE 2 & GAGE3 & Ra ns & L.ONG & SGERR & SIGAX & SIGSI \\
\hline & & & & & & & & \\
\hline $\begin{array}{l}-90 C-B \\
-90 C-C \\
-90 C-D \\
-90 C-E \\
-90 C-P\end{array}$ & $\begin{array}{r}98 \\
58 \\
50 \\
53 \\
55 \\
-21\end{array}$ & $\begin{array}{r}-387 \\
-278 \\
-238 \\
-198 \\
-159 \\
0\end{array}$ & $\begin{array}{r}-385 \\
0 \\
-203 \\
-174 \\
-155 \\
-19\end{array}$ & $\begin{array}{r}-17 \\
-6 \\
-9 \\
-8 \\
-6 \\
-\end{array}$ & $\begin{array}{r}-? \\
-1 \\
-1 \\
- \\
-\end{array}$ & $\begin{array}{r}-31 \\
-3653 \\
-383 \\
-319 \\
-54 \\
255\end{array}$ & $\begin{array}{r}-2175 \\
1532 \\
-1354 \\
-873 \\
-434 \\
-256\end{array}$ & $\begin{array}{l}-1 \\
2 \\
- \\
- \\
- \\
-\end{array}$ \\
\hline D & $\begin{array}{r}-17 \\
-38 \\
-35 \\
-26 \\
-16 \\
22\end{array}$ & $\begin{array}{r}-244 \\
-213 \\
-182 \\
-147 \\
-149 \\
-4\end{array}$ & $\begin{array}{r}-242 \\
-206 \\
-168 \\
-156 \\
-152 \\
8\end{array}$ & $\begin{array}{r}-10661 \\
-9178 \\
-7560 \\
-6635 \\
-6595 \\
63\end{array}$ & $\begin{array}{r}-35 \\
-38 \\
-33 \\
-27 \\
-24 \\
6\end{array}$ & $\begin{array}{r}-31 \\
-94 \\
-193 \\
128 \\
32 \\
-168\end{array}$ & $\begin{array}{r}-3695 \\
-3881 \\
-3347 \\
-2759 \\
-2470 \\
718\end{array}$ & $\begin{array}{r}-10661 \\
-9179 \\
-7659 \\
-6639 \\
-6595 \\
20\end{array}$ \\
\hline $\begin{array}{l}-90 n-B \\
-90 n-C \\
-90 n-D \\
-90 n-E \\
-90 n-P \\
-90 n-n\end{array}$ & $\begin{array}{r}168 \\
-147 \\
-126 \\
-69 \\
8 \\
41\end{array}$ & $\begin{array}{r}-334 \\
-191 \\
-100 \\
-50 \\
\vdots \\
27\end{array}$ & $\begin{array}{r}-236 \\
-212 \\
-112 \\
-57 \\
-161 \\
24\end{array}$ & $\begin{array}{r}-12709 \\
-8682 \\
-4527 \\
-2283 \\
-3485 \\
1077\end{array}$ & $\begin{array}{r}1 \\
-7 \\
-5 \\
-27 \\
-7 \\
1\end{array}$ & $\begin{array}{r}-1304 \\
285 \\
159 \\
96 \\
2189 \\
31\end{array}$ & $\begin{array}{r}1336 \\
-6977 \\
-4499 \\
-2254 \\
432 \\
1556\end{array}$ & $\begin{array}{r}-12929 \\
-8730 \\
-5188 \\
-2777 \\
-4708 \\
1075\end{array}$ \\
\hline $\begin{array}{l}-90 N-B \\
-90 N-C \\
-90 N-D \\
-90 N-E \\
-90 N-P\end{array}$ & $\begin{array}{r}83 \\
74 \\
-4 \\
-21 \\
-33 \\
10\end{array}$ & $\begin{array}{r}-178 \\
24 \\
69 \\
50 \\
17 \\
5\end{array}$ & $\begin{array}{r}-153 \\
31 \\
62 \\
45 \\
33 \\
5\end{array}$ & $\begin{array}{r}-7589 \\
1132 \\
2885 \\
2121 \\
1144 \\
212\end{array}$ & $\begin{array}{r}226 \\
2555 \\
735 \\
12 \\
-541 \\
357\end{array}$ & $\begin{array}{r}-190 \\
-96 \\
94 \\
64 \\
-220 \\
0\end{array}$ & $\begin{array}{r}231 \\
2561 \\
2890 \\
2123 \\
1171 \\
357\end{array}$ & $\begin{array}{r}-71 ; 94 \\
1125 \\
731 \\
10 \\
-568 \\
212\end{array}$ \\
\hline
\end{tabular}


Table A.l' (continued)

IR-PLARE MONENT LOADIMG, GEC, ON CYLIMDER (80000 IR-LB)

\begin{tabular}{|c|c|c|c|c|c|c|c|c|}
\hline \multirow[b]{2}{*}{ ROSETTE } & \multicolumn{3}{|c|}{$\begin{array}{l}\text { HICRO-STRAII } \\
\text { IITO- }\end{array}$} & \multicolumn{2}{|c|}{ STRESSES } & \multicolumn{3}{|c|}{ PRIR STRESSES } \\
\hline & GAGEI & A GE 2 & :1GE3 & HANS & LOWG & SHEAR & STGKX & IGER \\
\hline 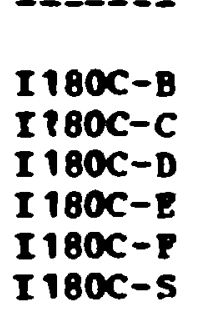 & $\begin{array}{r}-7 \\
-4 \\
-28 \\
-54 \\
-73 \\
-150\end{array}$ & $\begin{array}{r}144 \\
80 \\
52 \\
38 \\
26 \\
36\end{array}$ & $\begin{array}{r}130 \\
45 \\
14 \\
5 \\
3 \\
5\end{array}$ & $\begin{array}{r}6028 \\
2763 \\
1+94 \\
1006 \\
713 \\
1068\end{array}$ & $\begin{array}{r}1603 \\
694 \\
-389 \\
-1317 \\
-1972 \\
-4188\end{array}$ & $\begin{array}{l}190 \\
473 \\
503 \\
439 \\
314 \\
408\end{array}$ & $\begin{array}{r}6036 \\
2865 \\
1619 \\
1086 \\
750 \\
1099\end{array}$ & $\begin{array}{r}592 \\
-515 \\
-1397 \\
-2008 \\
-4219\end{array}$ \\
\hline $\begin{array}{l}C-B \\
C-C \\
C-D \\
C-E \\
=-P \\
=-5\end{array}$ & $\begin{array}{r}-43 \\
-71 \\
-95 \\
-114 \\
-130 \\
-132\end{array}$ & $\begin{array}{r}0 \\
-31 \\
-43 \\
-45 \\
-47 \\
-16\end{array}$ & $\begin{array}{r}10 \\
-12 \\
-28 \\
-36 \\
-32 \\
-16\end{array}$ & $\begin{array}{r}262 \\
-855 \\
-1450 \\
-1647 \\
-1599 \\
-554\end{array}$ & $\begin{array}{l}-1200 \\
-2391 \\
-3285 \\
-3914 \\
-4379 \\
-4116\end{array}$ & $\begin{array}{r}-126 \\
-254 \\
-190 \\
-127 \\
-191 \\
5\end{array}$ & $\begin{array}{r}273 \\
-814 \\
-1441 \\
-1639 \\
-1586 \\
-554\end{array}$ & $\begin{array}{l}-1210 \\
-2432 \\
-3305 \\
-3921 \\
-4392 \\
-4116\end{array}$ \\
\hline $\begin{array}{l}n-B \\
n-C \\
n-D= \\
n-E \\
n-E \\
n-n\end{array}$ & $\begin{array}{r}43 \\
67 \\
43 \\
36 \\
31 \\
2\end{array}$ & $\begin{array}{r}131 \\
69 \\
7 \\
50 \\
43 \\
0\end{array}$ & $\begin{array}{r}155 \\
95 \\
65 \\
72 \\
50 \\
0\end{array}$ & $\begin{array}{r}6247 \\
3546 \\
1633 \\
2637 \\
1996 \\
0\end{array}$ & $\begin{array}{r}3164 \\
3069 \\
1780 \\
1866 \\
1525 \\
73\end{array}$ & $\begin{array}{r}-317 \\
-349 \\
-326 \\
-286 \\
-93 \\
0\end{array}$ & $\begin{array}{r}6279 \\
3730 \\
2536 \\
2731 \\
2013 \\
73\end{array}$ & $\begin{array}{r}3132 \\
2884 \\
977 \\
1772 \\
1508 \\
0\end{array}$ \\
\hline $\begin{array}{l}0180 N-B \\
0180 N-C \\
0180 n-0 \\
0180 N-E \\
0180 N-P \\
0180 N-n\end{array}$ & $\begin{array}{l}24 \\
46 \\
51 \\
48 \\
45 \\
1\end{array}$ & $\begin{array}{r}-33 \\
-59 \\
-40 \\
-32 \\
-21 \\
3\end{array}$ & $\begin{array}{r}-33 \\
-59 \\
-64 \\
-45 \\
-35 \\
3\end{array}$ & $\begin{array}{r}-1475 \\
-2639 \\
-2333 \\
-1766 \\
-1297 \\
135\end{array}$ & $\begin{array}{r}288 \\
579 \\
820 \\
920 \\
975 \\
65\end{array}$ & $\begin{array}{r}2 \\
320 \\
164 \\
189 \\
0\end{array}$ & $\begin{array}{l}288 \\
579 \\
852 \\
930 \\
991 \\
135\end{array}$ & $\begin{array}{r}-1475 \\
-2639 \\
-2365 \\
-1776 \\
-1313 \\
65\end{array}$ \\
\hline
\end{tabular}


Table A.10 (continued)

IN-PLAME HOAENT LOADIMG, GZC, ON CTLIMDER (80000 IM-LB)

\begin{tabular}{|c|c|c|c|c|c|c|c|c|}
\hline \multirow[b]{2}{*}{ OSETTE } & \multicolumn{3}{|c|}{ AICRO-ST FAIM } & \multicolumn{3}{|c|}{ TRESSES } & \multicolumn{2}{|c|}{ PRIM STRESSES } \\
\hline & A GE 1 & GAGE 2 & E3 & ans & ONG & $\mathbf{R}$ & Gax & 34 \\
\hline 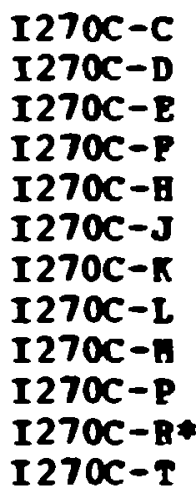 & $\begin{array}{r}48 \\
26 \\
26 \\
26 \\
24 \\
17 \\
12 \\
5 \\
-14 \\
-19 \\
168 \\
-22\end{array}$ & $\begin{array}{r}-265 \\
-217 \\
-193 \\
-181 \\
-164 \\
-118 \\
-122 \\
-96 \\
-67 \\
-17 \\
14 \\
77\end{array}$ & $\begin{array}{r}-236 \\
-193 \\
-191 \\
-164 \\
-131 \\
-119 \\
-112 \\
-91 \\
-74 \\
-26 \\
5 \\
60\end{array}$ & $\begin{array}{r}-11055 \\
-9039 \\
-8254 \\
-7624 \\
-6521 \\
-5886 \\
-5147 \\
-4116 \\
-3072 \\
-921 \\
237 \\
3024\end{array}$ & $\begin{array}{r}-1882 \\
-1921 \\
-1686 \\
-1496 \\
-1236 \\
-1261 \\
-1184 \\
-1089 \\
-1346 \\
-854 \\
5100 \\
261\end{array}$ & $\begin{array}{r}-381 \\
-317 \\
-159 \\
-222 \\
-445 \\
-381 \\
-127 \\
-79 \\
96 \\
126 \\
128 \\
223\end{array}$ & $\begin{array}{r}-1866 \\
-1907 \\
-1682 \\
-1488 \\
-1199 \\
-1230 \\
-1180 \\
-1087 \\
-1341 \\
-757 \\
5104 \\
3041\end{array}$ & $\begin{array}{r}-11071 \\
-9053 \\
-8258 \\
-7633 \\
-6558 \\
-5917 \\
-5151 \\
-4118 \\
-3077 \\
-1018 \\
234 \\
243\end{array}$ \\
\hline $\begin{array}{l}C-B \\
C-C \\
C-D \\
C-E \\
C-F \\
C-B \\
C-J \\
C-R \\
C-I \\
C-R \\
C-P \\
C-R \\
C-T\end{array}$ & $\begin{array}{r}-43 \\
-33 \\
-21 \\
-5 \\
10 \\
31 \\
45 \\
55 \\
60 \\
57 \\
34 \\
12 \\
-62\end{array}$ & $\begin{array}{r}-252 \\
-186 \\
-154 \\
-135 \\
-126 \\
-109 \\
-97 \\
-88 \\
-69 \\
-50 \\
-7 \\
19 \\
122\end{array}$ & $\begin{array}{r}-264 \\
-192 \\
-169 \\
-147 \\
-133 \\
-121 \\
-107 \\
-97 \\
-85 \\
-52 \\
0 \\
24 \\
0\end{array}$ & $\begin{array}{r}-11288 \\
-8264 \\
-7075 \\
-6205 \\
-5697 \\
-5093 \\
-4532 \\
-4128 \\
-3452 \\
-2303 \\
-185 \\
935 \\
2739\end{array}$ & $\begin{array}{r}-4665 \\
-3472 \\
-2758 \\
-1998 \\
-1418 \\
-593 \\
3 \\
408 \\
753 \\
1029 \\
952 \\
644 \\
-1025\end{array}$ & $\begin{array}{r}15 \\
9 \\
18 \\
15 \\
9 \\
15 \\
12 \\
12 \\
22 \\
3 \\
-9 \\
-6\end{array}$ & $\begin{array}{r}-4661 \\
-3470 \\
-2750 \\
-1992 \\
-1416 \\
-588 \\
6 \\
412 \\
765 \\
1029 \\
960 \\
948 \\
3340\end{array}$ & $\begin{array}{r}-11292 \\
-8266 \\
-7084 \\
-6211 \\
-5700 \\
-5099 \\
-4536 \\
-4131 \\
-3464 \\
-2303 \\
-193 \\
631 \\
-1626\end{array}$ \\
\hline $\begin{array}{l}\mathrm{I} 2 \\
\mathrm{I} 2 \\
\mathrm{I} 2 \\
\mathrm{I} 2 \\
\mathrm{I} 2\end{array}$ & $\begin{array}{r}168 \\
-140 \\
-131 \\
-71 \\
-40\end{array}$ & $\begin{array}{r}-338 \\
-231 \\
-131 \\
-107 \\
-41\end{array}$ & $\begin{array}{l}-283 \\
-224 \\
-131 \\
-71 \\
-45\end{array}$ & $\begin{array}{l}-138 \\
-98 \\
-56 \\
-38 \\
-19\end{array}$ & $\begin{array}{r}882 \\
-7161 \\
-5504 \\
-3281 \\
-1755\end{array}$ & $\begin{array}{r}-731 \\
-99 \\
0 \\
-479 \\
64\end{array}$ & $\begin{array}{r}918 \\
-1157 \\
-5604 \\
-3006 \\
-1723\end{array}$ & $\begin{array}{l}-13 \\
-9 \\
-5 \\
-4 \\
-1\end{array}$ \\
\hline $\begin{array}{l}02 \\
02 \\
02 \\
02 \\
02 \\
02 \\
02 \\
02\end{array}$ & $\begin{array}{r}97 \\
76 \\
5 \\
-40 \\
-50 \\
-43 \\
-38 \\
-16 \\
3\end{array}$ & $\begin{array}{r}-152 \\
38 \\
64 \\
50 \\
38 \\
17 \\
14 \\
-7 \\
C\end{array}$ & $\begin{array}{r}-138 \\
38 \\
76 \\
60 \\
43 \\
21 \\
14 \\
-5 \\
-2\end{array}$ & $\begin{array}{r}-6464 \\
1585 \\
3085 \\
2454 \\
1941 \\
987 \\
575 \\
-236 \\
-45\end{array}$ & $\begin{array}{r}979 \\
2752 \\
1073 \\
-472 \\
-940 \\
-1016 \\
-934 \\
-964 \\
65\end{array}$ & $\begin{array}{r}-189 \\
0 \\
-159 \\
-126 \\
-64 \\
-63 \\
0 \\
-31 \\
31\end{array}$ & $\begin{array}{r}9.34 \\
2752 \\
3097 \\
2460 \\
1843 \\
889 \\
6.15 \\
-233 \\
74\end{array}$ & $\begin{array}{r}-6469 \\
1585 \\
1061 \\
-478 \\
-941 \\
-1018 \\
-934 \\
-565 \\
-53\end{array}$ \\
\hline
\end{tabular}


Table A.1C (continuej)

IH-PLAME MOAENT LOADING, HZC, ON CTLIMDER (80000 In-LB)

HCRO-STERT

$--\infty-0-0$
STRESSES

sT

PRIn STRESSES

\begin{tabular}{|c|c|c|c|c|c|c|c|c|}
\hline St & & & & & & IE ant & $16 \pi x$ & 61. \\
\hline & & & & & -- & & . & --- \\
\hline $\begin{array}{l}:-B \\
:-C \\
:-D \\
:-P \\
:-H \\
:-J \\
:-R \\
:-I \\
-A \\
-P\end{array}$ & $\begin{array}{r}31 \\
7 \\
-14 \\
3 \\
-12 \\
-12 \\
-26 \\
-72 \\
-76 \\
-52\end{array}$ & $\begin{array}{r}-203 \\
-219 \\
-203 \\
-83 \\
-81 \\
-76 \\
-66 \\
-129 \\
-110 \\
-79\end{array}$ & $\begin{array}{r}3 \\
70 \\
84 \\
-19 \\
27 \\
24 \\
22 \\
24 \\
14 \\
-9\end{array}$ & $\begin{array}{r}-0426 \\
-3296 \\
-2601 \\
-2242 \\
-1171 \\
-1122 \\
-951 \\
-2236 \\
-2100 \\
-1882\end{array}$ & $\begin{array}{r}-391 \\
-766 \\
-1213 \\
-590 \\
-696 \\
-682 \\
-1058 \\
-2822 \\
-2919 \\
-2131\end{array}$ & $\begin{array}{r}-2738 \\
-3848 \\
-3822 \\
-859 \\
-1433 \\
-1336 \\
-1177 \\
-2046 \\
-1709 \\
-930\end{array}$ & $\begin{array}{r}992 \\
2020 \\
1977 \\
-224 \\
518 \\
452 \\
173 \\
-462 \\
-751 \\
-1068\end{array}$ & $\begin{array}{l}-5810 \\
-6082 \\
-5792 \\
-2607 \\
-2386 \\
-2255 \\
-2182 \\
-4596 \\
-4267 \\
-2944\end{array}$ \\
\hline $\begin{array}{l}-B \\
-C \\
-D \\
-8 \\
-8 \\
--1 \\
-R \\
-1 \\
-1 \\
-1 \\
-8\end{array}$ & $\begin{array}{l}-26 \\
-45 \\
-52 \\
-71 \\
-73 \\
-73 \\
-59 \\
-56 \\
-42 \\
-14\end{array}$ & $\begin{array}{r}24 \\
29 \\
38 \\
33 \\
-151 \\
24 \\
29 \\
39 \\
43 \\
39\end{array}$ & $\begin{array}{l}-199 \\
-194 \\
-261 \\
-249 \\
-247 \\
-227 \\
-180 \\
-149 \\
-130 \\
-85\end{array}$ & $\begin{array}{l}-3816 \\
-3586 \\
-4834 \\
-4555 \\
-8562 \\
-4379 \\
-3251 \\
-2359 \\
-1863 \\
-1002\end{array}$ & $\begin{array}{r}-1917 \\
-2419 \\
-3007 \\
-3527 \\
-4796 \\
-3500 \\
-2738 \\
-2395 \\
-1826 \\
-712\end{array}$ & $\begin{array}{l}37 \\
12 \\
33 \\
27 \\
24 \\
23 \\
16\end{array}$ & $\begin{array}{r}253 \\
23 \\
165 \\
-288 \\
-4417 \\
-561 \\
-204 \\
119 \\
465 \\
796\end{array}$ & $\begin{array}{l}-5986 \\
-6028 \\
-8006 \\
-7894 \\
-9041 \\
-7318 \\
-5785 \\
-4973 \\
-4154 \\
-2510\end{array}$ \\
\hline $\begin{array}{l}-B \\
-C \\
-D \\
-E \\
-P \\
-P\end{array}$ & $\begin{array}{r}108 \\
-50 \\
-50 \\
-21 \\
-9 \\
8\end{array}$ & $\begin{array}{r}-100 \\
-55 \\
-28 \\
-19 \\
-19 \\
3\end{array}$ & $\begin{array}{r}-103 \\
-100 \\
-43 \\
-5 \\
10 \\
-2\end{array}$ & $\begin{array}{r}-4580 \\
-3353 \\
-1512 \\
-492 \\
-190 \\
3\end{array}$ & $\begin{array}{r}18 \\
-25 \\
-19 \\
-7 \\
-3 \\
2\end{array}$ & $\begin{array}{r}31 \\
604 \\
191 \\
-190 \\
-382 \\
64\end{array}$ & $\begin{array}{r}1859 \\
-2192 \\
-1441 \\
-399 \\
125 \\
268\end{array}$ & $\begin{array}{r}-4580 \\
-3667 \\
-2026 \\
-880 \\
-653 \\
-12\end{array}$ \\
\hline $\begin{array}{l}-B \\
-C \\
-D \\
-B \\
-P \\
-G \\
-H \\
-R \\
-T\end{array}$ & $\begin{array}{r}50 \\
57 \\
26 \\
5 \\
0\end{array}$ & $\begin{array}{l}-33 \\
-14 \\
-12 \\
-19 \\
-21 \\
-21 \\
-19 \\
-7 \\
0\end{array}$ & $\begin{array}{r}-197 \\
-28 \\
26 \\
31 \\
28 \\
19 \\
17 \\
9 \\
.5\end{array}$ & $\begin{array}{r}-5095 \\
-986 \\
284 \\
254 \\
158 \\
-50 \\
-48 \\
56 \\
-43\end{array}$ & $\begin{array}{r}-35 \\
1425 \\
862 \\
219 \\
51 \\
58 \\
-12 \\
19 \\
-1541\end{array}$ & $\begin{array}{r}2185 \\
193 \\
-501 \\
-657 \\
-657 \\
-532 \\
-469 \\
-219 \\
63\end{array}$ & $\begin{array}{r}778 \\
1441 \\
1151 \\
894 \\
763 \\
539 \\
440 \\
257 \\
-40\end{array}$ & $\begin{array}{r}-5908 \\
-1001 \\
-5 \\
-421 \\
-554 \\
-530 \\
-590 \\
-182 \\
-1544\end{array}$ \\
\hline
\end{tabular}




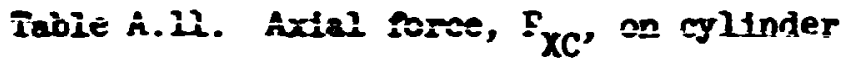

IIIL FonCE LONDIEG, SXC, OU CRINDER (10000 LB)

\begin{tabular}{|c|c|c|c|c|c|c|c|c|}
\hline \multirow[b]{2}{*}{ LOSETTE } & \multicolumn{3}{|c|}{ archo-sTEnIJ } & \multicolumn{2}{|c|}{ STAESSES } & \multicolumn{3}{|c|}{ PRIA STLESSES } \\
\hline & & & & Ans & Lows & SABAR & SIGax & STEI \\
\hline 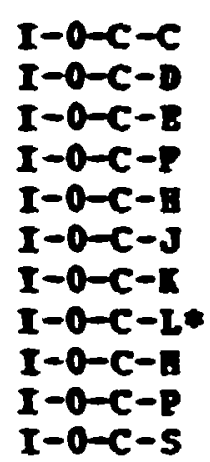 & $\begin{array}{r}-5 \\
5 \\
9 \\
14 \\
26 \\
33 \\
33 \\
-79 \\
31 \\
33 \\
26\end{array}$ & $\begin{array}{l}2 \\
14 \\
26 \\
31 \\
31 \\
33 \\
33 \\
31 \\
33 \\
33 \\
28\end{array}$ & $\begin{array}{l}2 \\
21 \\
24 \\
26 \\
33 \\
36 \\
33 \\
33 \\
33 \\
33 \\
29\end{array}$ & $\begin{array}{l}104 \\
776 \\
1085 \\
1239 \\
1381 \\
1477 \\
1424 \\
1495 \\
1429 \\
1423 \\
1225\end{array}$ & $\begin{array}{r}-115 \\
373 \\
609 \\
798 \\
1197 \\
1440 \\
1424 \\
-1914 \\
1355 \\
1424 \\
1147\end{array}$ & $\begin{array}{r}0 \\
-95 \\
32 \\
64 \\
-32 \\
-31 \\
1 \\
-32 \\
0 \\
1 \\
-3\end{array}$ & $\begin{array}{r}104 \\
797 \\
1087 \\
1248 \\
1387 \\
1495 \\
1425 \\
1496 \\
1429 \\
1424 \\
1226\end{array}$ & $\begin{array}{r}-115 \\
351 \\
607 \\
789 \\
1191 \\
1422 \\
1423 \\
-1914 \\
1355 \\
1422 \\
1147\end{array}$ \\
\hline 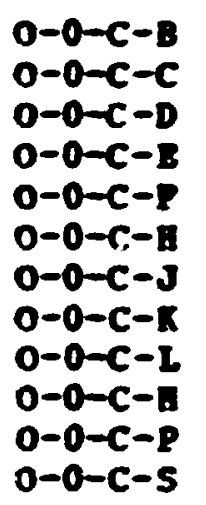 & $\begin{array}{r}-2 \\
5 \\
12 \\
17 \\
17 \\
21 \\
24 \\
26 \\
29 \\
26 \\
26 \\
17\end{array}$ & $\begin{array}{l}-26 \\
-28 \\
-21 \\
-24 \\
-26 \\
-26 \\
-31 \\
-28 \\
-31 \\
-31 \\
-31 \\
-28\end{array}$ & $\begin{array}{l}-24 \\
-21 \\
-21 \\
-24 \\
-21 \\
-28 \\
-28 \\
-31 \\
-31 \\
-33 \\
-31 \\
-35\end{array}$ & $\begin{array}{r}-1090 \\
-991 \\
-948 \\
-1056 \\
-1057 \\
-1218 \\
-1325 \\
-1327 \\
-1382 \\
-1432 \\
-1380 \\
-1422\end{array}$ & $\begin{array}{r}-396 \\
-153 \\
74 \\
184 \\
184 \\
276 \\
319 \\
389 \\
443 \\
356 \\
372 \\
77\end{array}$ & $\begin{array}{r}-32 \\
-31 \\
-1 \\
-1 \\
-63 \\
32 \\
-32 \\
32 \\
0 \\
32 \\
0 \\
95\end{array}$ & $\begin{array}{r}-394 \\
-152 \\
74 \\
184 \\
188 \\
279 \\
319 \\
389 \\
443 \\
357 \\
372 \\
82\end{array}$ & $\begin{array}{r}-1091 \\
-992 \\
-948 \\
-1056 \\
-1060 \\
-1219 \\
-1325 \\
-1327 \\
-1382 \\
-1433 \\
-1380 \\
-1428\end{array}$ \\
\hline $\begin{array}{l}-8 \\
-C \\
-1 \\
-E \\
-E \\
-1\end{array}$ & $\begin{array}{r}29 \\
3 \\
-2 \\
-2 \\
0 \\
0\end{array}$ & $\begin{array}{r}-31 \\
-31 \\
-24 \\
-19 \\
-14 \\
0\end{array}$ & $\begin{array}{l}-21 \\
-26 \\
-24 \\
-19 \\
-19 \\
-2\end{array}$ & $\begin{array}{r}-1184 \\
-1262 \\
-1048 \\
-837 \\
-732 \\
-45\end{array}$ & $\begin{array}{r}512 \\
-301 \\
-391 \\
-318 \\
-216 \\
-9\end{array}$ & $\begin{array}{r}-128 \\
-64 \\
0 \\
-1 \\
65 \\
31\end{array}$ & $\begin{array}{r}522 \\
-297 \\
-381 \\
-318 \\
-208 \\
9\end{array}$ & $\begin{array}{r}-1193 \\
-1266 \\
-1048 \\
-837 \\
-740 \\
-63\end{array}$ \\
\hline $\begin{array}{l}0-0-W-B \\
0-0-7-C \\
0-0-1-D \\
0-0-1-E \\
0-0-1-Z \\
0-0-Z-B \\
0-0-1-R\end{array}$ & $\begin{array}{r}12 \\
12 \\
5 \\
0 \\
0 \\
-2 \\
-5\end{array}$ & $\begin{array}{r}-12 \\
5 \\
12 \\
12 \\
9 \\
7\end{array}$ & $\begin{array}{r}-7 \\
7 \\
12 \\
9 \\
9 \\
5 \\
0 \\
-88\end{array}$ & $\begin{array}{r}-426 \\
254 \\
511 \\
466 \\
413 \\
261 \\
4 \\
-2043\end{array}$ & $\begin{array}{r}230 \\
436 \\
291 \\
136 \\
120 \\
-147 \\
-758\end{array}$ & $\begin{array}{r}-63 \\
-31 \\
-1 \\
31 \\
1 \\
32 \\
0 \\
1113\end{array}$ & $\begin{array}{r}236 \\
441 \\
511 \\
469 \\
413 \\
265 \\
4 \\
-116\end{array}$ & $\begin{array}{r}-43 \\
24 \\
29 \\
13 \\
12\end{array}$ \\
\hline
\end{tabular}


Sable A.II (continued)

AIIAL FORCE LOLDING, FXC, OU CILIMDER (10000 LB)

aICRO-STERI

--

MOSETTE GLGE1 GLGE2 GAGE3$$
\begin{array}{llll}
I-90 C-B & -10 \quad 112 & 115
\end{array}
$$$$
\begin{array}{lr}
I-90 C-B & -10 \\
I-90 C-C & 12 \\
I-90 C-D & 16 \\
I-90 C-B & 19 \\
I-90 C-I & 21 \\
I-90 C-B & -56
\end{array}
$$$$
\begin{array}{rr}
12 & 15 \\
81 & 0
\end{array}
$$

$\begin{array}{rr}61 & 0 \\ 64 & 67\end{array}$

$55 \quad 59$

$116 \quad 52$

43

$0-90 \mathrm{C}-\mathrm{B}-19$

$0-90 c-c \quad-2$

0-90c-D - -3

$0-90 c-2 \quad-36$

$0-90 C-P \quad-38$

$0-90 C-B * 14$

$I-90 I-B$
$I-90 I-C$
$I-90 I-D$
$I-90 I-B$
$I-90 I-P *$
$I-90 I-I$

$45 \quad 62$

26

31

31
19

17

14

17

40

TRES

STRESSES

PAIA STRESSES
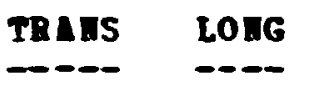

SRER R

SIGEX

SIGHI

4998

1769

1201

878

2860

2487

1352

1309

3674

1737

1886

$-1100$

$$
-33
$$

4999

2492

2861

2490

3992

1896

$\begin{array}{rr}19 & 1108 \\ 17 & 808 \\ 14 & 706 \\ 17 & 714 \\ 17 & 769 \\ 66 & 2841\end{array}$

$-242$

-242
-544
-717

$-857$

$-911$

1276

$-32$

$-64$

846

33

157

$1126-260$

$31 \quad 808-545$

$\begin{array}{lll}33 & 707 & -718\end{array}$

$-32$

715

769

$-28$

2841

$-858$

$-911$

\section{7}

31

2778

1232

2182

1011

247

14

10

529

1425

193

13

1423

340

$\begin{array}{rr}-63 & 2784 \\ -63 & 1249 \\ 96 & 601 \\ 63 & 537 \\ 1 & 1425 \\ 0 & 340\end{array}$

1275

$\begin{array}{ll}0-90 N-B & -5 \\ 0-901-C & -2 \\ 0-90 N-D & -7 \\ 0-90 \pi-B & -7 \\ 0-901-B & -7 \\ 0-90 \pi-B & -\end{array}$

$\begin{array}{rr}-55 & -14 \\ -2 ! & -24 \\ -7 & -24 \\ -7 & -17 \\ -7 & -14 \\ -5 & -5\end{array}$

$-19$

$-673-1843$

$63-670-1846$

$\begin{array}{lll}-29 & -1128 & -982\end{array}$

$\begin{array}{ll}-21 & -987\end{array}$

$-17-726$

$-514$

$-437$

$-17 \quad-674$

$-419$

$-208$

$64 \quad-958-1152$

$\begin{array}{lll}-31 & -512 & -989\end{array}$

$\begin{array}{lll}0 & -437 & -726\end{array}$

$\begin{array}{rrr}31 & -416 & -678 \\ 0 & -208 & -208\end{array}$ 
Table A.11 (continued)

AIIAL FORCB LOADIMg, FXC, ON CLIMDER (10000 LB)

\begin{tabular}{|c|c|c|c|c|c|c|c|c|}
\hline \multirow[b]{2}{*}{ ROSETTE } & \multicolumn{3}{|c|}{ nICRo-sTanI } & \multicolumn{3}{|c|}{ STRESSES } & \multicolumn{2}{|c|}{ PRII STRESSES } \\
\hline & GAGBI & GLGL2 & GAGB3 & TR A.TS & LOW6 & SEEAR & SIGHI & SIEA \\
\hline $\begin{array}{l}I 180 C-B \\
I 180 C-C \\
I 180 C-D \\
I 180 C-E \\
I 180 C-F \\
I 18 C C-S\end{array}$ & $\begin{array}{r}0 \\
4 \\
4 \\
11 \\
16 \\
35\end{array}$ & $\begin{array}{r}-10 \\
9 \\
18 \\
21 \\
26 \\
16\end{array}$ & $\begin{array}{r}-10 \\
11 \\
21 \\
23 \\
28 \\
13\end{array}$ & $\begin{array}{r}-431 \\
444 \\
858 \\
953 \\
1158 \\
604\end{array}$ & $\begin{array}{r}-139 \\
265 \\
383 \\
629 \\
834 \\
1217\end{array}$ & $\begin{array}{r}-2 \\
-33 \\
-32 \\
-31 \\
-31 \\
32\end{array}$ & $\begin{array}{r}-139 \\
250 \\
860 \\
956 \\
1161 \\
1219\end{array}$ & $\begin{array}{r}-431 \\
258 \\
381 \\
626 \\
831 \\
602\end{array}$ \\
\hline $\begin{array}{l}0180 C-B \\
0180 C-C \\
0180 C-D \\
0180 C-E \\
018 J C-F \\
0180 C-S\end{array}$ & $\begin{array}{r}2 \\
9 \\
13 \\
21 \\
21 \\
20\end{array}$ & $\begin{array}{l}-20 \\
-17 \\
-15 \\
-17 \\
-22 \\
-22\end{array}$ & $\begin{array}{l}-24 \\
-17 \\
-17 \\
-17 \\
-19 \\
-17\end{array}$ & $\begin{array}{l}-968 \\
-772 \\
-712 \\
-777 \\
-917 \\
-863\end{array}$ & $\begin{array}{r}-243 \\
26 \\
185 \\
385 \\
363 \\
328\end{array}$ & $\begin{array}{r}61 \\
3 \\
29 \\
-1 \\
-32 \\
-64\end{array}$ & $\begin{array}{r}-238 \\
26 \\
186 \\
385 \\
363 \\
332\end{array}$ & $\begin{array}{l}-973 \\
-772 \\
-713 \\
-777 \\
-918 \\
-866\end{array}$ \\
\hline $\begin{array}{l}\text { I 180N-B } \\
\text { I 180N-C } \\
\text { I 180N-D } \\
\text { I 180N-E } \\
\text { I 180N-F } \\
\text { I 180N-I }\end{array}$ & $\begin{array}{r}29 \\
0 \\
-7 \\
-5 \\
0 \\
-5\end{array}$ & $\begin{array}{r}-26 \\
-21 \\
0 \\
-19 \\
-15 \\
-2\end{array}$ & $\begin{array}{l}-38 \\
-40 \\
-31 \\
-31 \\
-19 \\
-2\end{array}$ & $\begin{array}{r}-1441 \\
-1358 \\
-668 \\
-1090 \\
-730 \\
-93\end{array}$ & $\begin{array}{r}431 \\
-404 \\
-412 \\
-456 \\
-232 \\
-167\end{array}$ & $\begin{array}{r}160 \\
254 \\
414 \\
160 \\
61 \\
1\end{array}$ & $\begin{array}{r}444 \\
-340 \\
-107 \\
-428 \\
-225 \\
-93\end{array}$ & $\begin{array}{r}-1454 \\
-1421 \\
-973 \\
-1129 \\
-746 \\
-167\end{array}$ \\
\hline $\begin{array}{l}0180 \pi-B \\
0180 \pi-C \\
01801-D \\
0 ; 80 \pi-E \\
C 180 \pi-F \\
0180 \pi-B\end{array}$ & $\begin{array}{r}9 \\
14 \\
7 \\
2 \\
0 \\
-3\end{array}$ & $\begin{array}{r}0 \\
17 \\
17 \\
14 \\
12 \\
-2\end{array}$ & $\begin{array}{r}-10 \\
9 \\
17 \\
14 \\
14 \\
-2\end{array}$ & $\begin{array}{r}-220 \\
555 \\
720 \\
623 \\
574 \\
-107\end{array}$ & $\begin{array}{r}216 \\
592 \\
426 \\
254 \\
17: \\
-107\end{array}$ & $\begin{array}{r}127 \\
95 \\
-1 \\
-1 \\
-32 \\
0\end{array}$ & $\begin{array}{r}251 \\
670 \\
720 \\
623 \\
576 \\
-107\end{array}$ & $\begin{array}{r}-254 \\
477 \\
426 \\
254 \\
168 \\
-107\end{array}$ \\
\hline
\end{tabular}


Tabie A.II (continued)

AIIKL FORCE LOADIMG, FIC, ON CIIIMDER (10000 LB)

\begin{tabular}{|c|c|c|c|c|c|c|c|c|}
\hline \multirow[b]{2}{*}{ OSETTE } & \multicolumn{3}{|c|}{ GICRO-ST BII } & \multicolumn{3}{|c|}{ STRESSES } & \multicolumn{2}{|c|}{ PRIA STEES SES } \\
\hline & GAGE1 & AGE2 & $\triangle G E 3$ & TRAMS & LONG & SHEAR & SIGRX & STGa: \\
\hline $\begin{array}{l}270 C-C \\
{[270 C-D} \\
{[270 C-E} \\
{[270 C-F} \\
{[270 C-B} \\
{[270 C-J} \\
{[270 C-K} \\
{[270 C-I} \\
{[270 C-E} \\
{[270 C-\bar{P}} \\
{[270 C-R} \\
{[270 C-T}\end{array}$ & $\begin{array}{r}7 \\
15 \\
14 \\
18 \\
14 \\
7 \\
0 \\
-19 \\
-31 \\
-52 \\
-58 \\
19\end{array}$ & $\begin{array}{l}77 \\
60 \\
54 \\
50 \\
45 \\
45 \\
40 \\
41 \\
33 \\
40 \\
33 \\
14\end{array}$ & $\begin{array}{l}72 \\
57 \\
52 \\
47 \\
35 \\
33 \\
31 \\
28 \\
31 \\
24 \\
33 \\
21\end{array}$ & $\begin{array}{l}3252 \\
2563 \\
2326 \\
2117 \\
1749 \\
1710 \\
1562 \\
1546 \\
1434 \\
1467 \\
1528 \\
744\end{array}$ & $\begin{array}{r}1197 \\
1204 \\
1117 \\
1054 \\
943 \\
718 \\
463 \\
-115 \\
-512 \\
-1132 \\
-1283 \\
794\end{array}$ & $\begin{array}{r}64 \\
33 \\
31 \\
32 \\
127 \\
158 \\
126 \\
168 \\
31 \\
224 \\
2 \\
-96\end{array}$ & $\begin{array}{l}3254 \\
2563 \\
2327 \\
2118 \\
1769 \\
1734 \\
1576 \\
1563 \\
1434 \\
1487 \\
1528 \\
868\end{array}$ & $\begin{array}{r}1195 \\
1204 \\
1116 \\
1054 \\
923 \\
693 \\
449 \\
-132 \\
-513 \\
-1151 \\
-1283 \\
670\end{array}$ \\
\hline 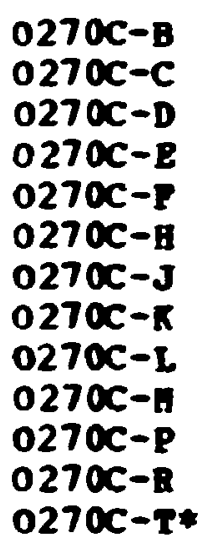 & $\begin{array}{l}-15 \\
-19 \\
-24 \\
-29 \\
-29 \\
-31 \\
-29 \\
-24 \\
-15 \\
-1 \\
13 \\
18 \\
-49\end{array}$ & $\begin{array}{l}24 \\
21 \\
19 \\
16 \\
19 \\
19 \\
21 \\
24 \\
31 \\
40 \\
49 \\
49 \\
21\end{array}$ & $\begin{array}{l}26 \\
24 \\
23 \\
21 \\
19 \\
21 \\
21 \\
26 \\
40 \\
42 \\
49 \\
47 \\
0\end{array}$ & $\begin{array}{r}1102 \\
1002 \\
956 \\
856 \\
856 \\
908 \\
955 \\
1112 \\
1569 \\
1800 \\
2147 \\
2096 \\
506\end{array}$ & $\begin{array}{r}-108 \\
-279 \\
-436 \\
-609 \\
-609 \\
-666 \\
-581 \\
-389 \\
33 \\
514 \\
1041 \\
1174 \\
-1316\end{array}$ & $\begin{array}{r}-30 \\
-32 \\
-61 \\
-63 \\
0 \\
-31 \\
-1 \\
-31 \\
-128 \\
-29 \\
-2 \\
32 \\
274\end{array}$ & $\begin{array}{r}1103 \\
1003 \\
958 \\
858 \\
856 \\
909 \\
955 \\
1113 \\
1579 \\
1801 \\
2147 \\
2097 \\
546\end{array}$ & $\begin{array}{r}-108 \\
-280 \\
-439 \\
-611 \\
-609 \\
-666 \\
-581 \\
-390 \\
23 \\
513 \\
1041 \\
1173 \\
-1356\end{array}$ \\
\hline $\begin{array}{l}\text { I } 270 \mathrm{~N}-\mathrm{B} \\
\text { I } 270 \mathrm{~N}-\mathrm{C} \\
\text { I } 270 \mathrm{~N}-\mathrm{D} \\
\text { I } 270 \mathrm{~N}-\mathrm{B} \\
\text { I } 270 \mathrm{~N}-\mathrm{P}\end{array}$ & $\begin{array}{r}38 \\
29 \\
9 \\
0 \\
-2\end{array}$ & $\begin{array}{l}76 \\
41 \\
24 \\
31 \\
17\end{array}$ & $\begin{array}{l}69 \\
40 \\
24 \\
17 \\
14\end{array}$ & $\begin{array}{l}3153 \\
1750 \\
1037 \\
1047 \\
683\end{array}$ & $\begin{array}{r}2088 \\
1381 \\
594 \\
311 \\
130\end{array}$ & $\begin{array}{r}95 \\
1 \\
0 \\
191 \\
32\end{array}$ & $\begin{array}{r}3162 \\
1750 \\
1037 \\
1094 \\
685\end{array}$ & $\begin{array}{r}2079 \\
1381 \\
594 \\
264 \\
129\end{array}$ \\
\hline $\begin{array}{l}0270 N-B \\
0270 N-C \\
0270 N-B \\
0270 n-E \\
0270 N-F \\
0270 N-G \\
0270 N-H \\
0270 N-K \\
0270 N-B\end{array}$ & $\begin{array}{r}-59 \\
-26 \\
-7 \\
0 \\
-3 \\
0 \\
0 \\
0 \\
-5\end{array}$ & $\begin{array}{l}-17 \\
-26 \\
-22 \\
-17 \\
-15 \\
-12 \\
-12 \\
-5 \\
-3\end{array}$ & $\begin{array}{l}-12 \\
-26 \\
-22 \\
-19 \\
-15 \\
-12 \\
-12 \\
-7 \\
-3\end{array}$ & $\begin{array}{r}-557 \\
-1115 \\
-942 \\
-793 \\
-639 \\
-527 \\
-533 \\
-273 \\
-114\end{array}$ & $\begin{array}{r}-1942 \\
-1115 \\
-504 \\
-244 \\
-273 \\
-162 \\
-168 \\
-92 \\
-188\end{array}$ & $\begin{array}{r}-63 \\
0 \\
1 \\
31 \\
1 \\
0 \\
0 \\
31 \\
0\end{array}$ & $\begin{array}{r}-554 \\
-1115 \\
-504 \\
-243 \\
-273 \\
-162 \\
-168 \\
-87 \\
-114\end{array}$ & $\begin{array}{l}-19 \\
-11 \\
-9 \\
-7 \\
-6 \\
-5 \\
-5 \\
-2 \\
-1\end{array}$ \\
\hline
\end{tabular}


AXIAL FoRCE LOAdEg. PIC, OA CTLIUDER (10000 LB)

\begin{tabular}{|c|c|c|c|c|c|c|c|c|}
\hline \multirow[b]{2}{*}{ ROSETTE } & \multicolumn{3}{|c|}{ nICRO-STRAT } & \multicolumn{3}{|c|}{ STRESSES } & \multicolumn{2}{|c|}{ PRIA STRESSES } \\
\hline & GAGE1 & GIGE2 & 23 & TRAus & 2016 & SARAR & SIGax & SIGA \\
\hline $\begin{array}{l}1315 c-8 \\
1315 c-c \\
1315 c-D \\
1315 c-8 \\
1315 c-1 \\
1315 c-d \\
1315 c-1 \\
1315 c-1 \\
1315 c-8 \\
1315 c-8\end{array}$ & $\begin{array}{r}-2 \\
9 \\
12 \\
14 \\
24 \\
26 \\
26 \\
29 \\
28 \\
19\end{array}$ & $\begin{array}{l}45 \\
48 \\
47 \\
25 \\
31 \\
31 \\
31 \\
38 \\
41 \\
46\end{array}$ & $\begin{array}{r}43 \\
31 \\
21 \\
26 \\
21 \\
19 \\
17 \\
2 \\
-10 \\
-32\end{array}$ & $\begin{array}{l}1939 \\
1715 \\
1492 \\
1186 \\
1120 \\
1066 \\
1015 \\
860 \\
650 \\
285\end{array}$ & $\begin{array}{r}508 \\
798 \\
806 \\
782 \\
1048 \\
1103 \\
1087 \\
1119 \\
1046 \\
641\end{array}$ & $\begin{array}{r}33 \\
223 \\
343 \\
32 \\
128 \\
159 \\
191 \\
485 \\
672 \\
1028\end{array}$ & $\begin{array}{l}1940 \\
1767 \\
1634 \\
1188 \\
1217 \\
1245 \\
1245 \\
1492 \\
1549 \\
1506\end{array}$ & $\begin{array}{r}508 \\
747 \\
664 \\
779 \\
951 \\
925 \\
857 \\
487 \\
147 \\
-580\end{array}$ \\
\hline $\begin{array}{l}0315 c-8 \\
0315 c-c \\
0315 c-d \\
0315 c-2 \\
0315 c-p \\
0315 c-8 \\
0315 c-x \\
0315 c-1 \\
0315 c-d \\
0315 c-p\end{array}$ & $\begin{array}{r}-10 \\
-7 \\
-2 \\
0 \\
-2 \\
0 \\
2 \\
11 \\
19 \\
31\end{array}$ & $\begin{array}{r}-43 \\
-40 \\
-45 \\
-45 \\
-119 \\
-41 \\
-31 \\
-31 \\
-19 \\
0\end{array}$ & $\begin{array}{l}38 \\
38 \\
52 \\
47 \\
47 \\
40 \\
38 \\
35 \\
38 \\
50\end{array}$ & $\begin{array}{r}-98 \\
-48 \\
156 \\
49 \\
-15 \in 5 \\
-14 \\
142 \\
74 \\
385 \\
1045\end{array}$ & $\begin{array}{r}-318 \\
-231 \\
-27 \\
13 \\
-543 \\
-17 \\
103 \\
365 \\
676 \\
1229\end{array}$ & $\begin{array}{r}-1075 \\
-1042 \\
-1256 \\
-1233 \\
-2213 \\
-1075 \\
-915 \\
-885 \\
-760 \\
-666\end{array}$ & $\begin{array}{r}872 \\
907 \\
1364 \\
1264 \\
1217 \\
1059 \\
1038 \\
1116 \\
1304 \\
1809\end{array}$ & $\begin{array}{r}-1288 \\
-1186 \\
-1235 \\
-1202 \\
-3326 \\
-1090 \\
-793 \\
-677 \\
-243 \\
165\end{array}$ \\
\hline 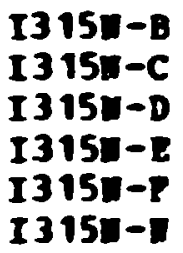 & $\begin{array}{r}31 \\
14 \\
5 \\
0 \\
0 \\
0\end{array}$ & $\begin{array}{l}5 \\
0 \\
0 \\
4 \\
9 \\
0\end{array}$ & $\begin{array}{r}36 \\
14 \\
0 \\
-3 \\
-3 \\
0\end{array}$ & $\begin{array}{r}854 \\
289 \\
-18 \\
39 \\
144 \\
-20\end{array}$ & $\begin{array}{r}1181 \\
510 \\
131 \\
2 \\
34 \\
7\end{array}$ & $\begin{array}{r}-413 \\
-190 \\
0 \\
94 \\
.58 \\
-1\end{array}$ & $\begin{array}{r}1462 \\
619 \\
131 \\
116 \\
257 \\
7\end{array}$ & $\begin{array}{l}574 \\
180 \\
-18 \\
-75 \\
-79 \\
-20\end{array}$ \\
\hline $\begin{array}{l}0315 \pi-B \\
0315 \pi-C \\
0315 \pi-D \\
0315 \pi-8 \\
0315 \pi-B \\
0315 \pi-6 \\
0315 \pi-\pi \\
0315 \pi-\pi \\
0315 \pi-\pi\end{array}$ & $\begin{array}{r}-25 \\
-7 \\
0 \\
0 \\
-2 \\
-2 \\
-2 \\
-2 \\
-36\end{array}$ & $\begin{array}{r}-31 \\
-15 \\
-7 \\
-2 \\
-2 \\
0 \\
-2 \\
0 \\
0\end{array}$ & $\begin{array}{r}19 \\
2 \\
0 \\
-2 \\
-2 \\
-2 \\
-5 \\
-5 \\
0\end{array}$ & $\begin{array}{r}-242 \\
-262 \\
-158 \\
-105 \\
-105 \\
-54 \\
-155 \\
-106 \\
35\end{array}$ & $\begin{array}{r}-830 \\
-300 \\
-50 \\
-34 \\
-106 \\
-91 \\
-121 \\
-105 \\
-1078\end{array}$ & $\begin{array}{r}-667 \\
-223 \\
-93 \\
1 \\
0 \\
31 \\
31 \\
63 \\
0\end{array}$ & $\begin{array}{r}192 \\
-57 \\
3 \\
-34 \\
-105 \\
-37 \\
-102 \\
-42 \\
35\end{array}$ & $\begin{array}{r}-1264 \\
-505 \\
-212 \\
-105 \\
-106 \\
-108 \\
-174 \\
-168 \\
-1078\end{array}$ \\
\hline
\end{tabular}


Table A.12. In-plane force, $F_{Y C}$, on cylinder

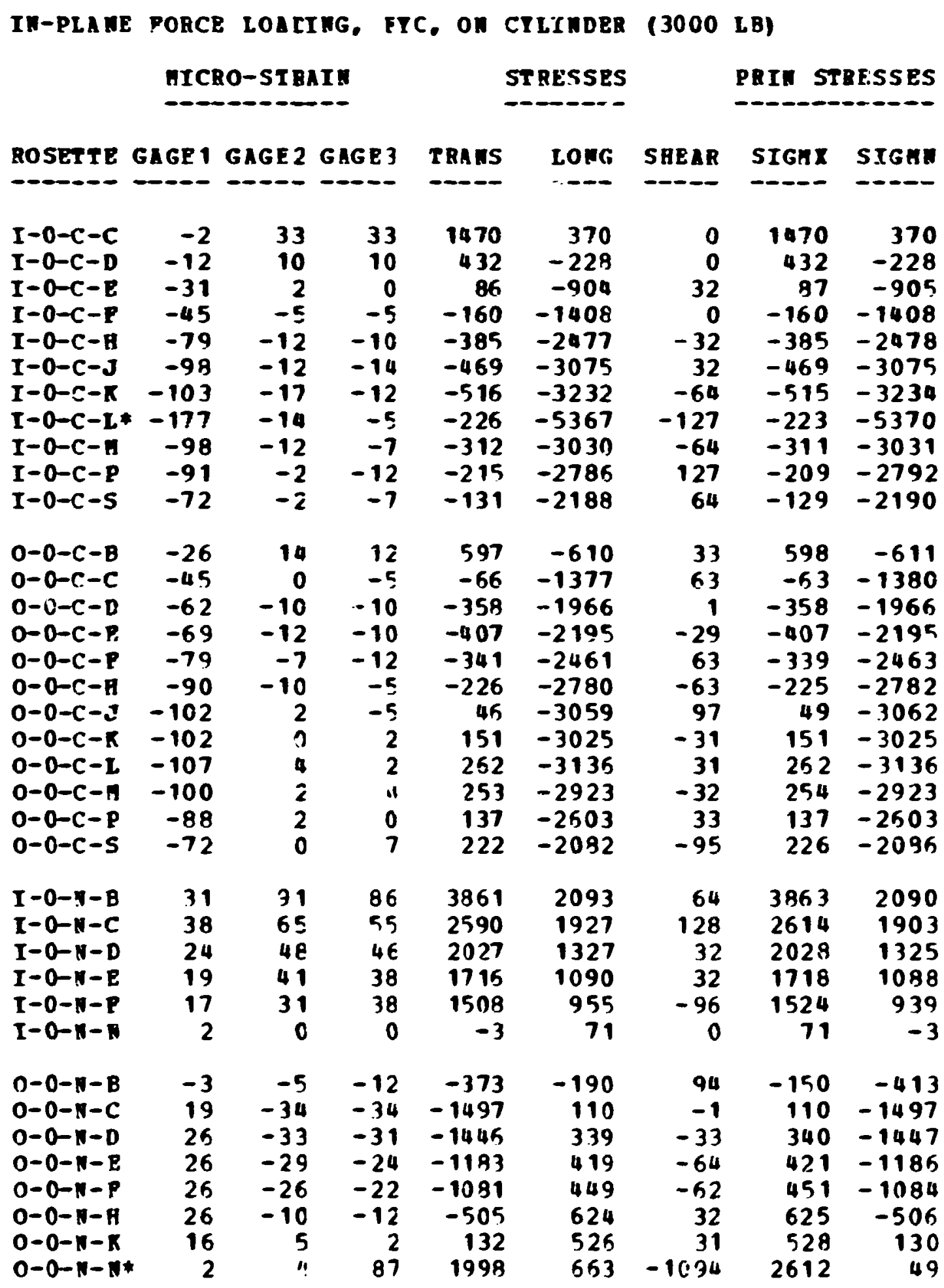


Tat:- A.12 (ecr:ir.izs)

In-PLADE PORCE LOATIE, FIC, OH CILIUDER (3000 LB)

grcso-st BAIA

- - - - - - -
STRESSES

$-\infty-\infty$
PRIN STRESSES

$\rightarrow-\infty-\infty-\infty$

\begin{tabular}{|c|c|c|c|c|c|c|c|c|}
\hline SETT & & & & & 0.0 & & $\boldsymbol{x}$ & \\
\hline $\begin{array}{l}-90 C-B \\
-90 C-C \\
-90 C-D \\
-90 C-E \\
-90 C-P\end{array}$ & $\begin{array}{l}65 \\
26 \\
17 \\
14 \\
14 \\
10\end{array}$ & $\begin{array}{r}-287 \\
-199 \\
-163 \\
-139 \\
-106 \\
31\end{array}$ & $\begin{array}{r}-297 \\
0 \\
-167 \\
-146 \\
-132 \\
-33\end{array}$ & $\begin{array}{r}-129111 \\
-1393 \\
-7275 \\
-6273 \\
-5116 \\
-63\end{array}$ & $\begin{array}{r}-1933 \\
-529 \\
-1680 \\
-1151 \\
-1104\end{array}$ & $\begin{array}{r}128 \\
-2546 \\
64 \\
96 \\
814 \\
861\end{array}$ & $\begin{array}{r}-1931 \\
816 \\
-1679 \\
-1450 \\
-1062 \\
979\end{array}$ & $\begin{array}{l}-12 \\
-5 \\
-7 \\
-6 \\
-5 \\
-\end{array}$ \\
\hline $\begin{array}{l}-90 c-1 \\
-90 c-C \\
-90 c-D \\
-90 c-E \\
-90 c-P \\
-90 c-1\end{array}$ & $\begin{array}{r}2 \\
-5 \\
-2 \\
7 \\
14 \\
-5\end{array}$ & $\begin{array}{l}-171 \\
-142 \\
-123 \\
-102 \\
-104 \\
-58\end{array}$ & $\begin{array}{r}-150 \\
-123 \\
-112 \\
-93 \\
-90 \\
31\end{array}$ & $\begin{array}{l}-70 \\
-59 \\
-51 \\
-42 \\
-42 \\
-1\end{array}$ & $\begin{array}{l}-18 \\
-10 \\
-8 \\
-\end{array}$ & $\begin{array}{l}-286 \\
-253 \\
-158 \\
-126 \\
-190 \\
-917\end{array}$ & $\begin{array}{l}-20 \\
-18 \\
-10 \\
-10 \\
-8\end{array}$ & $\begin{array}{l}-7 \\
-5 \\
-5 \\
-4 \\
-4 \\
-1\end{array}$ \\
\hline $\begin{array}{l}-90 \pi-B \\
-90 \pi-C \\
-90 \pi-D \\
-90 \pi-E \\
-90 \pi-P \\
-90 \pi-D\end{array}$ & $\begin{array}{r}78 \\
-197 \\
-79 \\
-38 \\
-12 \\
24\end{array}$ & $\begin{array}{r}-234 \\
-136 \\
-69 \\
-41 \\
-17 \\
17\end{array}$ & $\begin{array}{r}-194 \\
-153 \\
-79 \\
-43 \\
-103 \\
14\end{array}$ & $\begin{array}{r}-9256 \\
-6277 \\
-3166 \\
-1795 \\
-2608 \\
656\end{array}$ & $\begin{array}{r}-558 \\
-5100 \\
-3320 \\
-1590 \\
-1140 \\
913\end{array}$ & $\begin{array}{r}-668 \\
191 \\
126 \\
31 \\
1144 \\
32\end{array}$ & $\begin{array}{r}-507 \\
-5073 \\
-3095 \\
-1582 \\
-515 \\
917\end{array}$ & $\begin{array}{r}-9307 \\
-6308 \\
-3391 \\
-1804 \\
-3233 \\
652\end{array}$ \\
\hline $\begin{array}{l}-3 \\
-C \\
-D \\
-2\end{array}$ & $\begin{array}{r}81 \\
57 \\
0 \\
-7 \\
-19 \\
12\end{array}$ & $\begin{array}{r}-9 \\
2 \\
5 \\
2\end{array}$ & $\begin{array}{r}-78 \\
31 \\
50 \\
38 \\
28\end{array}$ & $\begin{array}{r}-39 \\
12 \\
22 \\
17 \\
11 \\
3\end{array}$ & $\begin{array}{r}123 \\
208 \\
68 \\
32 \\
-9\end{array}$ & $\begin{array}{r}-25 \\
-3 \\
6 \\
6 \\
-9\end{array}$ & $\begin{array}{l}1248 \\
2983 \\
2297 \\
1783 \\
1118 \\
146\end{array}$ & $\begin{array}{r}-3960 \\
1240 \\
686 \\
318 \\
-101 \\
300\end{array}$ \\
\hline
\end{tabular}


Fabie A.i2 fontiriej"

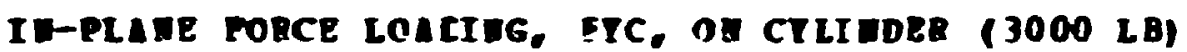

\begin{tabular}{|c|c|c|c|c|c|c|c|c|}
\hline \multirow[b]{2}{*}{ DosetTE } & \multicolumn{3}{|c|}{ arces-stand } & \multicolumn{3}{|c|}{ STRESSES } & \multicolumn{2}{|c|}{ PRID STRESSES } \\
\hline & E & GIG52 & GE3 & 12 & .016 & FE $\mathbf{A R}$ & $\operatorname{sign} x$ & SIGE \\
\hline $\begin{array}{l}1180 c-B \\
1180 c-C \\
1180 c-D \\
Y 180 c-E \\
1180 c-F \\
\text { I } 180 c-5\end{array}$ & $\begin{array}{r}-5 \\
-2 \\
-21 \\
-82 \\
-50 \\
-151\end{array}$ & $\begin{array}{r}92 \\
42 \\
19 \\
5 \\
-2 \\
-2\end{array}$ & $\begin{array}{r}68 \\
26 \\
2 \\
-7 \\
-12 \\
-12\end{array}$ & $\begin{array}{r}3528 \\
1505 \\
490 \\
-5 \\
-246 \\
-145\end{array}$ & $\begin{array}{r}917 \\
381 \\
-490 \\
-1275 \\
-1862 \\
-4570\end{array}$ & $\begin{array}{l}314 \\
220 \\
220 \\
157 \\
126 \\
126\end{array}$ & $\begin{array}{r}3566 \\
1567 \\
537 \\
14 \\
-236 \\
-142\end{array}$ & $\begin{array}{r}880 \\
339 \\
-537 \\
-1294 \\
-1852 \\
-4574\end{array}$ \\
\hline $\begin{array}{l}180 C-B \\
180 C-C \\
180 C-D \\
180 C-E \\
180 C-P \\
180 C-5 *\end{array}$ & $\begin{array}{r}-26 \\
-50 \\
-69 \\
-93 \\
-105 \\
0\end{array}$ & $\begin{array}{r}12 \\
-5 \\
-16 \\
-16 \\
-24 \\
12\end{array}$ & $\begin{array}{r}22 \\
3 \\
-7 \\
-12 \\
-17 \\
-10\end{array}$ & $\begin{array}{r}758 \\
11 \\
-390 \\
-530 \\
-773 \\
52\end{array}$ & $\begin{array}{r}-548 \\
-1487 \\
-2178 \\
-2650 \\
-3371 \\
15\end{array}$ & $\begin{array}{r}-126 \\
-96 \\
-94 \\
-63 \\
-95 \\
285\end{array}$ & $\begin{array}{r}780 \\
18 \\
-395 \\
-528 \\
-770 \\
320\end{array}$ & $\begin{array}{r}-560 \\
-1493 \\
-2183 \\
-2652 \\
-3378 \\
-252\end{array}$ \\
\hline $\begin{array}{l}I 180 n-B \\
1180 n-C \\
I 180 n-D * \\
I 180 n-2 \\
1180 n-P \\
I 180 n-n\end{array}$ & $\begin{array}{r}12 \\
10 \\
28 \\
28 \\
21 \\
2\end{array}$ & $\begin{array}{r}97 \\
54 \\
5 \\
43 \\
35 \\
-1\end{array}$ & $\begin{array}{r}117 \\
81 \\
59 \\
54 \\
42 \\
0\end{array}$ & $\begin{array}{r}4696 \\
2929 \\
1316 \\
2317 \\
1586 \\
-22\end{array}$ & $\begin{array}{r}1751 \\
2085 \\
1243 \\
1401 \\
1143 \\
55\end{array}$ & $\begin{array}{r}-257 \\
-350 \\
-764 \\
-289 \\
-94 \\
-2\end{array}$ & $\begin{array}{r}4 ? 09 \\
3055 \\
2044 \\
2400 \\
1702 \\
55\end{array}$ & $\begin{array}{r}1729 \\
1959 \\
515 \\
1318 \\
1127 \\
-22\end{array}$ \\
\hline $\begin{array}{l}0180 N-B \\
0180 N-C \\
0180 N-0 \\
0189 n-E \\
0180 n-P \\
0180 n-N\end{array}$ & $\begin{array}{r}-9 \\
21 \\
26 \\
31 \\
29 \\
0\end{array}$ & $\begin{array}{r}-19 \\
-6 C \\
-38 \\
-31 \\
-21 \\
2\end{array}$ & $\begin{array}{l}-17 \\
-43 \\
-50 \\
-35 \\
-31 \\
2\end{array}$ & $\begin{array}{r}-778 \\
-2061 \\
-1952 \\
-1645 \\
-1181 \\
105\end{array}$ & $\begin{array}{r}-375 \\
24 \\
196 \\
494 \\
502 \\
31\end{array}$ & $\begin{array}{r}-29 \\
-95 \\
158 \\
32 \\
127 \\
0\end{array}$ & $\begin{array}{r}-373 \\
28 \\
208 \\
494 \\
511 \\
105\end{array}$ & $\begin{array}{r}-776 \\
-2066 \\
-1978 \\
-1445 \\
-1190\end{array}$ \\
\hline
\end{tabular}




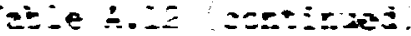

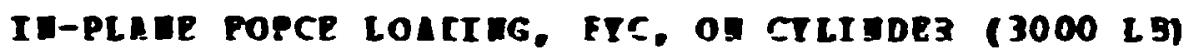

nICBO-STHAIA
STRESSES

(2) pris spesses

$-\cdots-1-0-1$

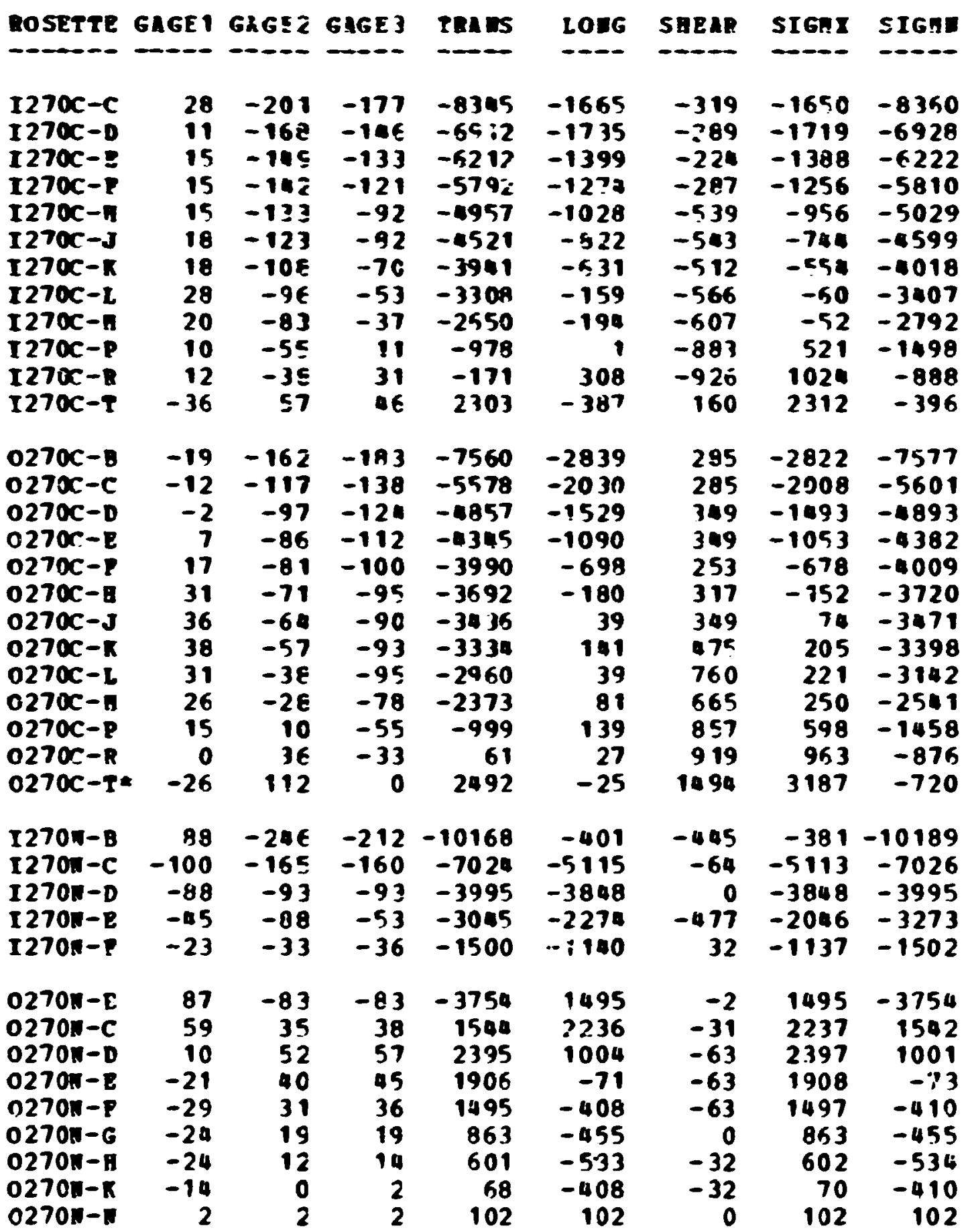


Tabis A.12 (continued)

ID-PLAE FOACE LOATIG, FYC, ON CTLIMDER (3030 LB)

SICRO-STEAT

(1)
STRESSES

$-0$
PRI STRESSES

roserTE

I3 15C-B

13 ise-c

I $315 \mathrm{C}-\mathrm{D}$

$1315 \mathrm{C}-\mathrm{P}$

I3 $15 \mathrm{C}-\mathrm{E}$

I3 $15 \mathrm{C}-\mathrm{J}$

I3isc-

$1315 C-1$

$1315 c-9$

$1315 \mathrm{C}-\mathrm{P}$

$0385 C-B$

$0315 c-c$

$0315 C-0$

$0315 \mathrm{C}-\mathrm{z}$

$3315 \mathrm{C}-\mathrm{P}$

$0315 \mathrm{C}-\mathrm{B}$ *

$0315 \mathrm{C}-\pi$

$0315 C-L$

$0315 c-18$

$0315 C-P$

I3 15N-B

I $315 \pi-C$

I $315 \pi-D$

I $3: 5 n-E$

$1315 \pi-F$

I315H-11*

$0315 \pi-8$

$0315 \pi-C$

$0315 \pi-D$

$0315 \pi-8$

$0315 \pi-P$

$0315 \pi-6$

$0315 \pi-7$

$0315 \pi-K$

$0315 n-n$

$$
\begin{array}{rr}
19 & -161 \\
2 & -155 \\
-14 & -101 \\
-7 & -62 \\
-17 & -6: \\
-19 & -55 \\
-26 & -48 \\
-65 & -8: \\
-69 & -60 \\
-57 & -61
\end{array}
$$

$-14$

$-28$

$-33$

$-50$

$-50$

0
-55

$-52$

$-52$

$-55$

$\begin{array}{rr}57 & -6 \\ -38 & -3 \\ -33 & -1 \\ -10 & -1 \\ -5 & -1 \\ -2 & \end{array}$

32

36

43

38

33

5

GAEE?

Tmans

$$
\begin{array}{rr}
-14 & -3431 \\
31 & -2731 \\
45 & -2193 \\
-21 & -1928 \\
10 & -1136 \\
12 & -923 \\
14 & -70 \\
31 & -103 i \\
29 & -607 \\
26 & -252
\end{array}
$$

$-1073$

$-1000$

$-2245$

$-2262$

$-1797$

$$
-138-2278
$$

$-1110$

$$
43
$$

36

$-59-596$

$-40$

$-44$

$-1650$

$$
\begin{array}{ll}
-79 & -3163
\end{array}
$$

$-57-2165$

$\begin{array}{ll}-26 & -962\end{array}$

$$
-2
$$

$$
-299
$$

$-100$

$-459-10256$

772
-1797

$-1293$

$$
\begin{array}{rr}
45 & -5 \\
43 & 5 \\
17 & -4 \\
5 & -9 \\
1 & -11 \\
3 & -11 \\
3 & -9 \\
3 & -6 \\
-42 & 3
\end{array}
$$

$-133$

$-1$

$-3073$

$-255$

257

259

124

75

55

74

174
SAEAR

LOIG

-.-

$-=57$

$-748$

$-763$

$-842$

$-850$

$-1686$

$-2 \pm 81$

$-2517$

$-541$

$-958$

$-891$

$-827$

$-1497$

-1179
-892

$-1496$

2276

2240

3034

2844

2750

$245 ?$

1895

1801

1485

1011

223

$-520$

$-173$

.3148

SIGHX SIGAX

--- - -

$$
304-4192
$$

$933-4411$

$966-4181$

$-537-2055$

$-23-1955$

$5-1778$

$-13-1693$

$-24-j>55$

$6-28 ; 5$

$155-2205$

$655-4043$

$469-4061$

$643-5523$

$\begin{array}{lll}311 & -5394\end{array}$

$185-5335$

$936-4392$

$50-3777$

$628-3131$

$485-2721$

$444-2138$

$785-3175$

$-1499-2463$

$-936-1318$

$-241-578$

$121-394$

$516-13920$

$-255$

6283

$430 \quad 1707$

$1124-376 ?$

$1247-298$

75199

$656-167$

$456-284$

$435-248$

$369-197$

$251-69$

$174-1193$ 
Table A.13. Out-of-plane force, $F_{2 C^{\prime}}$ on cylinder

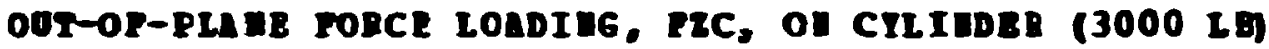

AICRO-SERII

$-\infty-\infty-\infty-\infty-0$
GIG21 GIGL2 GLGB3

\begin{tabular}{|c|c|c|c|c|c|c|c|c|}
\hline $\begin{array}{l}-2 \\
-2 \\
-9 \\
-3 \\
-1 \\
-12 \\
-2 \\
-2 \\
-5\end{array}$ & $\begin{array}{r}-2 \\
0 \\
0 \\
0 \\
-2 \\
-2 \\
2 \\
-138 \\
-2 \\
-5 \\
-7\end{array}$ & $\begin{array}{l}-45 \\
-60 \\
-52 \\
-50 \\
29 \\
26 \\
-41 \\
-43 \\
-41 \\
-36 \\
-36\end{array}$ & $\begin{array}{r}31 \\
41 \\
38 \\
38 \\
-45 \\
-43 \\
21 \\
21 \\
26 \\
29 \\
26\end{array}$ & $\begin{array}{l}-312 \\
-419 \\
-315 \\
-262 \\
-364 \\
-364 \\
-422 \\
-320 \\
-312 \\
-152 \\
-202\end{array}$ & $\begin{array}{r}-165 \\
-126 \\
-94 \\
-79 \\
-181 \\
-181 \\
-55 \\
-1249 \\
-165 \\
-189 \\
-275\end{array}$ & $\begin{array}{r}-1017 \\
-1335 \\
-1208 \\
-1176 \\
985 \\
922 \\
-826 \\
-859 \\
-890 \\
-859 \\
-827\end{array}$ & $\begin{array}{r}781 \\
1070 \\
1008 \\
1009 \\
717 \\
654 \\
608 \\
-141 \\
655 \\
688 \\
589\end{array}$ & $\begin{array}{l}-1258 \\
-1615 \\
-1117 \\
-1350 \\
-1262 \\
-1199 \\
-1085 \\
-1128 \\
-1132 \\
-1029 \\
-1066\end{array}$ \\
\hline-5 & $\begin{array}{r}0 \\
2 \\
-3 \\
0 \\
5 \\
-3 \\
2 \\
-3 \\
0 \\
-3 \\
-3 \\
-5\end{array}$ & $\begin{array}{l}54 \\
54 \\
59 \\
57 \\
52 \\
50 \\
45 \\
42 \\
42 \\
40 \\
38 \\
40\end{array}$ & $\begin{array}{l}-45 \\
-40 \\
-43 \\
-43 \\
-45 \\
-36 \\
-33 \\
-33 \\
-29 \\
-26 \\
-31 \\
-29\end{array}$ & $\begin{array}{l}204 \\
302 \\
361 \\
304 \\
144 \\
307 \\
249 \\
202 \\
305 \\
307 \\
151 \\
257\end{array}$ & $\begin{array}{r}57 \\
158 \\
31 \\
85 \\
178 \\
15 \\
137 \\
-18 \\
83 \\
14 \\
-33 \\
-74\end{array}$ & $\begin{array}{r}1328 \\
1264 \\
1359 \\
1329 \\
1295 \\
1138 \\
1045 \\
1011 \\
948 \\
884 \\
917 \\
917\end{array}$ & $\begin{array}{r}1460 \\
1497 \\
1566 \\
1527 \\
1457 \\
1308 \\
1239 \\
1109 \\
1148 \\
1057 \\
981 \\
1023\end{array}$ & $\begin{array}{r}-1199 \\
-1035 \\
-1173 \\
-1139 \\
-1134 \\
-986 \\
-853 \\
-925 \\
-760 \\
-736 \\
-863 \\
-840\end{array}$ \\
\hline-0 & $\begin{array}{r}-5 \\
-12 \\
-16 \\
-7 \\
-5 \\
0\end{array}$ & $\begin{array}{r}-12 \\
0 \\
0 \\
-5 \\
-5 \\
0\end{array}$ & $\begin{array}{r}-19 \\
-17 \\
-16 \\
-2 \\
0 \\
0\end{array}$ & $\begin{array}{r}-679 \\
-355 \\
-200 \\
-150 \\
-100 \\
0\end{array}$ & $\begin{array}{r}-347 \\
-466 \\
-347 \\
-261 \\
-174 \\
0\end{array}$ & $\begin{array}{r}96 \\
223 \\
128 \\
-32 \\
-64 \\
0\end{array}$ & $\begin{array}{r}-322 \\
-180 \\
-126 \\
-141 \\
-63 \\
0\end{array}$ & $\begin{array}{r}-705 \\
-611 \\
=421 \\
-269 \\
-211 \\
0\end{array}$ \\
\hline $\begin{array}{l}-0 \\
-0- \\
-0-\end{array}$ & $\begin{array}{r}0 \\
-3 \\
-3 \\
-3 \\
-3 \\
0 \\
2 \\
0\end{array}$ & $\begin{array}{r}19 \\
2 \\
-5 \\
-7 \\
-3 \\
-7 \\
-5 \\
0\end{array}$ & $\begin{array}{r}-17 \\
2 \\
9 \\
7 \\
7 \\
7 \\
2 \\
-1\end{array}$ & $\begin{array}{r}45 \\
96 \\
100 \\
-3 \\
100 \\
-5 \\
-59 \\
-21\end{array}$ & $\begin{array}{r}8 \\
-49 \\
-48 \\
-78 \\
-47 \\
-6 \\
46 \\
-12\end{array}$ & $\begin{array}{r}474 \\
-1 \\
-191 \\
-190 \\
-126 \\
-189 \\
-95 \\
8\end{array}$ & $\begin{array}{r}500 \\
96 \\
230 \\
153 \\
172 \\
184 \\
102 \\
-7\end{array}$ & $\begin{array}{r}-447 \\
-49 \\
-178 \\
-234 \\
-120 \\
-195 \\
-115 \\
-26\end{array}$ \\
\hline
\end{tabular}

SEBAR

Trns

Long

- - - - - - - -

SIGNI SIGED

PRIE STESSES

STDESSES 
Table A.13 (continued)

\begin{tabular}{|c|c|c|c|c|c|c|c|c|}
\hline \multirow[b]{2}{*}{ BOSLTTE } & \multicolumn{3}{|c|}{ VICRO-STEAII } & \multicolumn{3}{|c|}{ STRESSES } & \multicolumn{2}{|c|}{ PRIU STREss ES } \\
\hline & 6E1 & & & & t & SABAR & IGaX & SIG \\
\hline $\begin{array}{l}I-90 C-B \\
I-90 C-C \\
I-90 C-D \\
I-90 C-B \\
I-90 C-1 \\
I-90 C-8\end{array}$ & $\begin{array}{r}-5 \\
-3 \\
-5 \\
-10 \\
-10 \\
-24\end{array}$ & $\begin{array}{l}43 \\
62 \\
69 \\
62 \\
65 \\
98\end{array}$ & $\begin{array}{r}-10 \\
0 \\
-36 \\
-34 \\
-29 \\
83\end{array}$ & $\begin{array}{r}735 \\
1366 \\
627 \\
631 \\
812 \\
1013\end{array}$ & $\begin{array}{r}70 \\
331 \\
39 \\
-105 \\
-51 \\
477\end{array}$ & $\begin{array}{r}701 \\
826 \\
1339 \\
1275 \\
1257 \\
192\end{array}$ & $\begin{array}{l}1178 \\
1823 \\
1104 \\
1590 \\
1710 \\
1023\end{array}$ & $\begin{array}{r}-373 \\
-127 \\
-1038 \\
-1065 \\
-949 \\
466\end{array}$ \\
\hline $\begin{array}{l}0-90 C-D \\
0-90 C-C \\
0-90 C-D * \\
0-90 C-B \\
0-90 C-P \\
0-90 C-D\end{array}$ & $\begin{array}{r}7 \\
5 \\
2 \\
0 \\
-2 \\
-43\end{array}$ & $\begin{array}{r}-17 \\
-36 \\
-33 \\
-33 \\
-28 \\
93\end{array}$ & $\begin{array}{r}47 \\
62 \\
-147 \\
62 \\
69 \\
102\end{array}$ & $\begin{array}{r}66 * \\
568 \\
-3965 \\
626 \\
889 \\
4322\end{array}$ & $\begin{array}{r}103 \\
313 \\
-1119 \\
188 \\
196 \\
16\end{array}$ & $\begin{array}{r}-854 \\
-1296 \\
1517 \\
-1265 \\
-1296 \\
-126\end{array}$ & $\begin{array}{l}1395 \\
1743 \\
-461 \\
1690 \\
1284 \\
4326\end{array}$ & $\begin{array}{r}-333 \\
-062 \\
-4622 \\
-877 \\
-799 \\
12\end{array}$ \\
\hline $\begin{array}{l}I-90 X-B \\
I-90 I-C \\
I-90 X-D \\
I-90 I-Z \\
I-90 I-P * \\
I-90 N-D\end{array}$ & $\begin{array}{r}-10 \\
-10 \\
0 \\
0 \\
21 \\
-22\end{array}$ & $\begin{array}{r}-12 \\
-17 \\
-7 \\
0 \\
-41 \\
-12\end{array}$ & $\begin{array}{r}-17 \\
-8 \\
0 \\
-5 \\
2 \\
-12\end{array}$ & $\begin{array}{l}-619 \\
-609 \\
-158 \\
-107 \\
-862 \\
-518\end{array}$ & $\begin{array}{r}-472 \\
-409 \\
-47 \\
-36 \\
385 \\
-811\end{array}$ & $\begin{array}{r}64 \\
-191 \\
-95 \\
63 \\
-572 \\
0\end{array}$ & $\begin{array}{r}-448 \\
-218 \\
8 \\
1 \\
608 \\
-518\end{array}$ & $\begin{array}{r}-642 \\
-600 \\
-212 \\
-144 \\
-1085 \\
-811\end{array}$ \\
\hline $\begin{array}{l}0-90 n-B \\
0-90 \pi-C \\
0-90 n-D \\
0-90 n-E \\
0-90 n-P \\
0-90 n-P\end{array}$ & $\begin{array}{r}-5 \\
0 \\
2 \\
4 \\
4 \\
2\end{array}$ & $\begin{array}{r}-9 \\
-2 \\
2 \\
7 \\
4 \\
0\end{array}$ & $\begin{array}{r}38 \\
0 \\
-12 \\
-7 \\
-7 \\
2\end{array}$ & $\begin{array}{r}631 \\
-52 \\
-211 \\
-15 \\
-68 \\
38\end{array}$ & $\begin{array}{r}47 \\
-16 \\
8 \\
124 \\
112 \\
75\end{array}$ & $\begin{array}{r}-632 \\
-32 \\
190 \\
189 \\
157 \\
-32\end{array}$ & $\begin{array}{r}1035 \\
3 \\
117 \\
256 \\
203 \\
93\end{array}$ & $\begin{array}{r}-358 \\
-70 \\
-321 \\
-147 \\
-159 \\
20\end{array}$ \\
\hline
\end{tabular}


Tabie A.13 (cortinued)

OOT-OF-PLAEE FORCE LOADIN, FEC, OA CILIMDER (3000 id

GiCRO-ST baI"

-
STRESSES

- - -

RRIM STRESSES

BOSETTE GAGE1 GAGE2 GAGE3

I180C-E

I $180 C-C$

$I 1800-D$

I180C-8

I180C-P

I 180C-5

$0180 \mathrm{C}-\mathrm{B}$

$0180 c-c$

$0180 C-D$

$0180 \mathrm{C}-\mathrm{E}$

$0180 \mathrm{C}-\mathrm{F}$

$0180 c-5$

I1801-B

I 180E-C

I 1802-D

I1601-2

I1801-P

I 180I-W

01801-B

$0180 \pi-C$

$01800-0$

01801-8

$0180 \pi-2$

0180n-n

$\begin{array}{rr}2 & -26 \\ 2 & -5 \\ 2 & -55 \\ 2 & -5 \\ 2 & -5 \\ -1 & -29\end{array}$

55

555

559

5 5E

o 50

0 2E

$-2 \quad-2$

$-2$

0

$-2$

2

2

o

0

$\begin{array}{rr}-10 & 16 \\ -5 & -5 \\ -5 & -14 \\ -2 & -14 \\ 0 & -12 \\ 0 & 0\end{array}$
Ten us

\section{3}

$-\infty-$

LOn6

SHEAB

--

142

$-119$

$-171$

$-327$

$-325$

$-22$

$\begin{array}{ll}106 & -787\end{array}$

$28-1321$

$8-1351$

$-35-1319$

$-33-1194$

$-24 \quad-754$

$-45198$

$-45$

$-50$

$-46$

$-56$

$-36$

196

200

146

0

$-209$

$-12$

$-7$

$-7$

2

-309
-153
-205
134
144

196

195

196

180

0

$-63$

1331

1333

1458

1364

1350

824

$\begin{array}{ll}-163 & 128\end{array}$

$-116$

$-61$

104

106

2

128
95

64

0
-96

0

$-206$

$-157$

$-219$

$-256$

$-154$

$-104$

$-118$

$-95$

$-222$

$-285$

$-31 \quad-253$

SIGAX SIGAU

--. -.-

$911-663$

$1278-1368$

$1273-1435$

$1146-1509$

$1024-1382$

$732-777$

$1529-1134$

$1528-1137$

$1656-1261$

$1527-1200$

$1330-1330$

$691-963$

$-89-383$

$-37 \quad-232$

$-37 \quad-231$

$104 \quad 104$

$222 \quad 28$

32

$397 \quad-537$

$6 \quad-212$

$-15-460$

$150-\$ 22$

$188-328$

$0-32$ 
Tabie A.13 (continued)

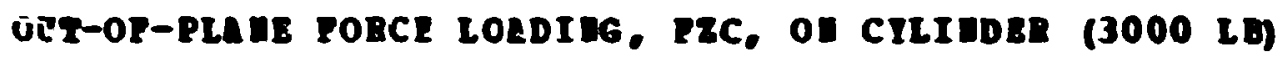

GICRC-STEIID

ROSETYE BAGE1 GAGE2 GAGE3

\begin{tabular}{|c|c|c|c|c|c|c|c|c|}
\hline 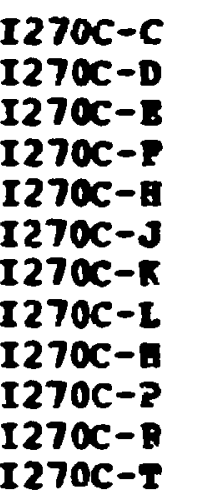 & $\begin{array}{r}-2 \\
-2 \\
0 \\
0 \\
0 \\
4 \\
4 \\
14 \\
14 \\
36 \\
43 \\
-17\end{array}$ & $\begin{array}{r}26 \\
25 \\
28 \\
21 \\
7 \\
-10 \\
-22 \\
-39 \\
-53 \\
-88 \\
-96 \\
-26\end{array}$ & $\begin{array}{r}-76 \\
-76 \\
-74 \\
-76 \\
-70 \\
-72 \\
-77 \\
-86 \\
-101 \\
-100 \\
-105 \\
22\end{array}$ & $\begin{array}{r}-1093 \\
-1040 \\
-1017 \\
-1175 \\
-1385 \\
-1804 \\
-2169 \\
-2777 \\
-3392 \\
-4190 \\
-4468 \\
-87\end{array}$ & $\begin{array}{l}-396 \\
-380 \\
-318 \\
-366 \\
-430 \\
-411 \\
-516 \\
-413 \\
-604 \\
-179 \\
-49 \\
-529\end{array}$ & $\begin{array}{r}1367 \\
1399 \\
1366 \\
1271 \\
1017 \\
825 \\
730 \\
623 \\
634 \\
161 \\
128 \\
-638\end{array}$ & $\begin{array}{r}666 \\
727 \\
743 \\
564 \\
216 \\
-28 \\
-240 \\
-259 \\
-466 \\
-173 \\
-44 \\
367\end{array}$ & $\begin{array}{r}-2155 \\
-2147 \\
-2078 \\
-2104 \\
-2031 \\
-2187 \\
-2446 \\
-2931 \\
-3529 \\
-4196 \\
-4472 \\
-983\end{array}$ \\
\hline 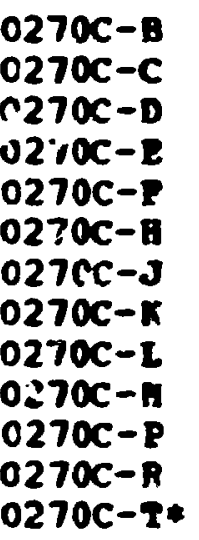 & $\begin{array}{l}7 \\
7 \\
14 \\
16 \\
16 \\
21 \\
28 \\
33 \\
38 \\
40 \\
35 \\
31 \\
7\end{array}$ & $\begin{array}{r}-57 \\
-60 \\
-62 \\
-67 \\
-64 \\
-67 \\
-72 \\
-79 \\
-88 \\
-98 \\
-107 \\
-108 \\
10\end{array}$ & $\begin{array}{r}48 \\
4 C \\
36 \\
33 \\
31 \\
19 \\
5 \\
-5 \\
-38 \\
-53 \\
-81 \\
-105 \\
9\end{array}$ & $\begin{array}{r}-216 \\
-433 \\
-598 \\
-759 \\
-759 \\
-1079 \\
-1402 \\
-1770 \\
-2823 \\
-3348 \\
-4181 \\
-4645 \\
929\end{array}$ & $\begin{array}{r}151 \\
78 \\
243 \\
266 \\
266 \\
312 \\
429 \\
462 \\
289 \\
203 \\
-191 \\
-172 \\
483\end{array}$ & $\begin{array}{r}-1396 \\
-1332 \\
-1299 \\
-1331 \\
-1268 \\
-11111 \\
-1079 \\
-919 \\
-666 \\
-602 \\
-350 \\
0 \\
568\end{array}$ & $\begin{array}{r}1375 \\
1179 \\
1187 \\
1180 \\
1121 \\
953 \\
928 \\
791 \\
426 \\
302 \\
-161 \\
-472 \\
1316\end{array}$ & $\begin{array}{r}-1440 \\
-1534 \\
-1543 \\
-1673 \\
-1614 \\
-1719 \\
-1901 \\
-2100 \\
-2960 \\
-3447 \\
-4211 \\
-4645 \\
96\end{array}$ \\
\hline $\begin{array}{l}2701-12 \\
2701-c \\
2701-0 \\
2701-1 \\
2701-1\end{array}$ & $\begin{array}{r}-14 \\
-5 \\
0 \\
5 \\
7\end{array}$ & $\begin{array}{r}-19 \\
-17 \\
-7 \\
-7 \\
2\end{array}$ & $\begin{array}{r}-19 \\
-2 \\
C \\
-2 \\
-5\end{array}$ & $\begin{array}{r}-823 \\
-414 \\
-157 \\
-215 \\
-63\end{array}$ & $\begin{array}{r}-677 \\
-268 \\
-47 \\
79 \\
183\end{array}$ & $\begin{array}{r}0 \\
-191 \\
-95 \\
-64 \\
96\end{array}$ & $\begin{array}{r}-677 \\
-137 \\
8 \\
92 \\
216\end{array}$ & $\begin{array}{r}-923 \\
-545 \\
-212 \\
-228 \\
-96\end{array}$ \\
\hline $\begin{array}{l}0270 n-B \\
0270 \pi-C \\
02701-D \\
0270 n-B \\
0270 n-R \\
0270 n-G \\
0270 \pi-A \\
02701-R \\
0270 n-A\end{array}$ & $\begin{array}{r}16 \\
5 \\
0 \\
0 \\
0 \\
0 \\
0 \\
0 \\
2\end{array}$ & $\begin{array}{r}-22 \\
12 \\
14 \\
12 \\
10\end{array}$ & $\begin{array}{r}2 \varepsilon \\
9 \\
0 \\
-7 \\
-7 \\
-7 \\
-6 \\
-2 \\
c\end{array}$ & $\begin{array}{r}132 \\
302 \\
263 \\
157 \\
107 \\
52 \\
53 \\
54 \\
-1\end{array}$ & $\begin{array}{r}530 \\
229 \\
80 \\
47 \\
33 \\
15 \\
17 \\
18 \\
13\end{array}$ & $\begin{array}{r}-665 \\
-63 \\
159 \\
286 \\
253 \\
222 \\
159 \\
95 \\
0\end{array}$ & $\begin{array}{l}1025 \\
335 \\
354 \\
393 \\
325 \\
256 \\
195 \\
133 \\
73\end{array}$ & $\begin{array}{r}-363 \\
193 \\
-12 \\
-189 \\
-186 \\
-189 \\
-125 \\
-61 \\
-1\end{array}$ \\
\hline
\end{tabular}

PRID STRESSES

STRESSES

SABAR

SIGAX SIGEU

reans

I016

$---$ 
Mable A.I3 (continued)

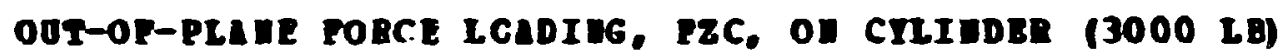

\begin{tabular}{|c|c|c|c|c|c|c|c|c|}
\hline \multirow[b]{2}{*}{ Roswite } & \multicolumn{3}{|c|}{ GICRO-STEAIU } & \multicolumn{3}{|c|}{ STBESSES } & \multicolumn{2}{|c|}{ PRIU STRESSES } \\
\hline & GIGET & GDGEZ & IGE3 & TEN & Lons & SERAR & SIGEX & SIGA \\
\hline $\begin{array}{l}315 C-B \\
315 C-C \\
315 C-D \\
315 C-P \\
315 C-B \\
115 C-J \\
315 C-R \\
315 C-I \\
315 C-A \\
315 C-P\end{array}$ & $\begin{array}{r}9 \\
5 \\
0 \\
-10 \\
-12 \\
-15 \\
-15 \\
7 \\
-3 \\
-10\end{array}$ & $\begin{array}{l}-96 \\
-74 \\
-62 \\
-41 \\
-41 \\
-43 \\
-50 \\
-69 \\
-75 \\
-91\end{array}$ & $\begin{array}{l}-84 \\
-62 \\
-45 \\
-39 \\
-39 \\
-34 \\
-31 \\
-24 \\
-10 \\
-3\end{array}$ & $\begin{array}{l}-3957 \\
-3009 \\
-2333 \\
-1734 \\
-1737 \\
-1679 \\
-1782 \\
-2058 \\
-1943 \\
-2045\end{array}$ & $\begin{array}{l}-905 \\
-766 \\
-695 \\
-816 \\
-890 \\
-945 \\
-977 \\
-902 \\
-651 \\
-912\end{array}$ & $\begin{array}{r}-157 \\
-159 \\
-262 \\
-32 \\
-31 \\
-127 \\
-255 \\
-600 \\
-922 \\
-1174\end{array}$ & $\begin{array}{l}-897 \\
-755 \\
-654 \\
-815 \\
-889 \\
-923 \\
-903 \\
-208 \\
-179 \\
-175\end{array}$ & $\begin{array}{l}-3965 \\
-3020 \\
-2374 \\
-1735 \\
-1739 \\
-1701 \\
-1856 \\
-2253 \\
-2425 \\
-2782\end{array}$ \\
\hline $\begin{array}{l}0315 c \\
0315 C \\
0315 c \\
0315 c \\
0315 c \\
0315 c \\
0315 C \\
0315 C \\
0315 C \\
0315 C\end{array}$ & $\begin{array}{r}7 \\
7 \\
12 \\
19 \\
24 \\
24 \\
26 \\
19 \\
14 \\
0\end{array}$ & $\begin{array}{r}-19 \\
-10 \\
-5 \\
-3 \\
-10 \\
2 \\
\vdots \\
\vdots \\
10 \\
12 \\
7\end{array}$ & $\begin{array}{l}-41 \\
-31 \\
-38 \\
-38 \\
-38 \\
-4 C \\
-52 \\
-69 \\
-81 \\
-88\end{array}$ & $\begin{array}{r}-1319 \\
-904 \\
-958 \\
-915 \\
-1079 \\
-860 \\
-1071 \\
-1220 \\
-1527 \\
-1772\end{array}$ & $\begin{array}{r}-262 \\
-65 \\
61 \\
291 \\
381 \\
454 \\
61 \\
203 \\
-31 \\
-532\end{array}$ & $\begin{array}{r}284 \\
286 \\
442 \\
474 \\
376 \\
569 \\
758 \\
1106 \\
1233 \\
1264\end{array}$ & $\begin{array}{r}-191 \\
23 \\
226 \\
455 \\
472 \\
666 \\
773 \\
807 \\
662 \\
256\end{array}$ & $\begin{array}{r}-1391 \\
-993 \\
-1123 \\
-1079 \\
-1170 \\
-1072 \\
-1383 \\
-1823 \\
-2221 \\
-2560\end{array}$ \\
\hline 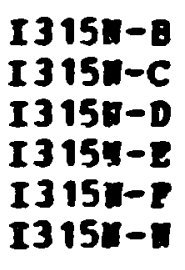 & $\begin{array}{l}-7 \\
-38 \\
-29 \\
-17 \\
-12 \\
-1\end{array}$ & $\begin{array}{r}-69 \\
-48 \\
-29 \\
-19 \\
-15 \\
c\end{array}$ & $\begin{array}{r}-81 \\
-48 \\
-27 \\
-19 \\
-15 \\
0\end{array}$ & $\begin{array}{r}-3307 \\
-2068 \\
-1186 \\
-831 \\
-627 \\
-12\end{array}$ & $\begin{array}{r}-1213 \\
-1774 \\
-1222 \\
-758 \\
-553 \\
-44\end{array}$ & $\begin{array}{r}160 \\
1 \\
-32 \\
-1 \\
-1 \\
-1\end{array}$ & $\begin{array}{r}-1201 \\
-1774 \\
-1167 \\
-758 \\
-553 \\
-12\end{array}$ & $\begin{array}{r}-3319 \\
-2068 \\
-1241 \\
-831 \\
-627 \\
-44\end{array}$ \\
\hline $\begin{array}{l}03151 \\
03151 \\
03151 \\
03151 \\
03151 \\
03151 \\
03151 \\
03151 \\
03151\end{array}$ & $\begin{array}{r}19 \\
7 \\
-6 \\
-14 \\
-14 \\
-12 \\
-10 \\
-3 \\
-9\end{array}$ & $\begin{array}{r}-21 \\
17 \\
20 \\
16 \\
13 \\
10 \\
7 \\
-1 \\
4\end{array}$ & $\begin{array}{r}-24 \\
12 \\
23 \\
19 \\
12 \\
6 \\
8 \\
8 \\
4\end{array}$ & $\begin{array}{r}-1011 \\
612 \\
961 \\
788 \\
583 \\
408 \\
335 \\
31 \\
192\end{array}$ & $\begin{array}{r}266 \\
399 \\
104 \\
-177 \\
-243 \\
-236 \\
-199 \\
-94 \\
-221\end{array}$ & $\begin{array}{r}32 \\
63 \\
-39 \\
-35 \\
12 \\
21 \\
-6 \\
-48 \\
-2\end{array}$ & $\begin{array}{r}267 \\
635 \\
963 \\
789 \\
534 \\
409 \\
335 \\
47 \\
192\end{array}$ & $\begin{array}{r}-1012 \\
382 \\
103 \\
-178 \\
-243 \\
-237 \\
-199 \\
-110 \\
-221\end{array}$ \\
\hline
\end{tabular}

